Portland State University

PDXScholar

Spring 5-29-2013

\title{
The Effect of Temperature on Phenotypes of the Invasive European Green Crab: Physiologic Mechanisms that Facilitate Invasion Success
}

Amanda Kelley

Portland State University

Follow this and additional works at: https://pdxscholar.library.pdx.edu/open_access_etds

Part of the Marine Biology Commons, and the Other Animal Sciences Commons Let us know how access to this document benefits you.

Recommended Citation

Kelley, Amanda, "The Effect of Temperature on Phenotypes of the Invasive European Green Crab: Physiologic Mechanisms that Facilitate Invasion Success" (2013). Dissertations and Theses. Paper 1004. https://doi.org/10.15760/etd.1004

This Dissertation is brought to you for free and open access. It has been accepted for inclusion in Dissertations and Theses by an authorized administrator of PDXScholar. Please contact us if we can make this document more accessible: pdxscholar@pdx.edu. 
The Effect of Temperature on Phenotypes of the Invasive European Green Crab:

Physiologic Mechanisms that Facilitate Invasion Success

by

Amanda Kelley

A dissertation submitted in partial fulfillment of the requirements for the degree of

\author{
Doctor of Philosophy \\ in \\ Biology
}

Dissertation Committee:

Suzanne Estes, Chair

Catherine de Rivera

Jason Podrabsky

Susan Masta

Gwen Shusterman

Portland State University

2013 
(C) 2013 Amanda Kelley 


\section{ABSTRACT}

Invasion physiology is an emerging field that endeavors to understand the influence of physiological traits on the establishment of non-native species in novel environments. The invasive European green crab, Carcinus maenas, is one of the world's most successful aquatic invaders, and is currently distributed across temperate marine ecosystems globally. The work presented here explored the thermal physiology of this species, and has highlighted several physiological traits that have likely influenced establishment success.

Intraspecific comparisons of crabs sampled from the northern and southern edges of their recipient, or invaded range on the west coast of North America have identified both organismal and cellular physiological difference with respect to upper and lower thermal tolerances. Crabs sampled from British Columbia, Canada (BC) had a significantly lower mean upper thermal tolerance threshold and heat shock protein synthesis, Hsp70, compared to their warm acclimated conspecifics sampled from California (CA). These differential physiologic responses may be rooted in the disparate natural thermal habitats that each population occupies within their respective environments.

The ability of this species to extend its current range limits was also investigated. Range expansion to the south has been limited, and is likely restricted by this species lack of adaptation to warmer temperatures. Because range expansion has been chiefly northward, characterizing this species' 
response to cold stress can identify whether colder temperatures poleward may limit further range expansion. Cold tolerance capacity was determined in the laboratory, and crabs sampled from Vancouver Island, British Columbia were able to withstand the over-wintering thermal regime that occurs in Sitka, Alaska, a site that is currently beyond the range limits of this species. Furthermore, intraspecific assessments found that the cold acclimated BC population exposed to cold shock significantly down regulated protein levels of cyclin D1, cell cycle modulator.

Distinct differences in carapace width $(\mathrm{CW})$ were detected along the thermal gradient present in the green crabs' range. This variation in body size was utilized to the test the temperature size rule hypothesis for ectotherms. Simply stated, the temperature size rule is the tendency for ectotherms to develop slower but mature to a larger body sizes at cooler temperatures. The results supported this hypothesis as crabs sampled from the warm portion of the range were found to be smaller than crabs sampled from the colder portion of the range. This pattern was detected along the native range as well. Differences in body size have the potential to influence the scope of invasion; larger individuals are generally more fecund and longer lived, which can increase both the intensity and frequency of larval dispersal that could further propel range expansion.

The physiologic properties that the green crab possesses which may influence invasion success were examined using peer-reviewed literature with the aim of determining if these physiological traits confer invasion success across 
taxa. This analysis tested four hypotheses: 1) Broad geographic temperature tolerances (thermal width) confer a higher upper thermal tolerance threshold when comparing invasive and native species. 2) The upper thermal extreme experienced in nature is correlated with upper thermal tolerance threshold. 3) Protein chaperone expression, a cellular mechanism underlying thermal tolerance threshold, is greater in invasive organisms than in native ones. 4) Acclimation to higher temperatures can promote a greater range of thermal tolerance for invasives compared to natives. These preliminary results generally support the four stated hypotheses, and provide a solid foundation for further studies to explore and identify physiologic traits that facilitate invasion success.

Overall, these studies investigated the thermal physiology of Carcinus maenas from an invasive metapopulation and have brought about significant advances in our understanding of what physiologic traits correlate to invasion success in this species. In addition, the data presented here can aid resource managers in identifying habitats, based on thermal tolerance measurements that fit the criteria for invasion. Understanding how invasive organisms vary with respect to thermal tolerance can aid our understanding the patterns and processes of species invasions. 


\section{DEDICATION}

I would like to dedicate this body of work to my wonderful partner, Allison Carr, who has supported me, emotionally and otherwise, through the past several years. Thank you for being so understanding throughout the process of this endeavor.

Second, I would like to dedicate this to my wonderful companion, Mr. Jed. Thank you for being a huge part of my life over the past 13 years, and for always being there for me. Nothing will ever take your place in my heart. I will miss you eternally.

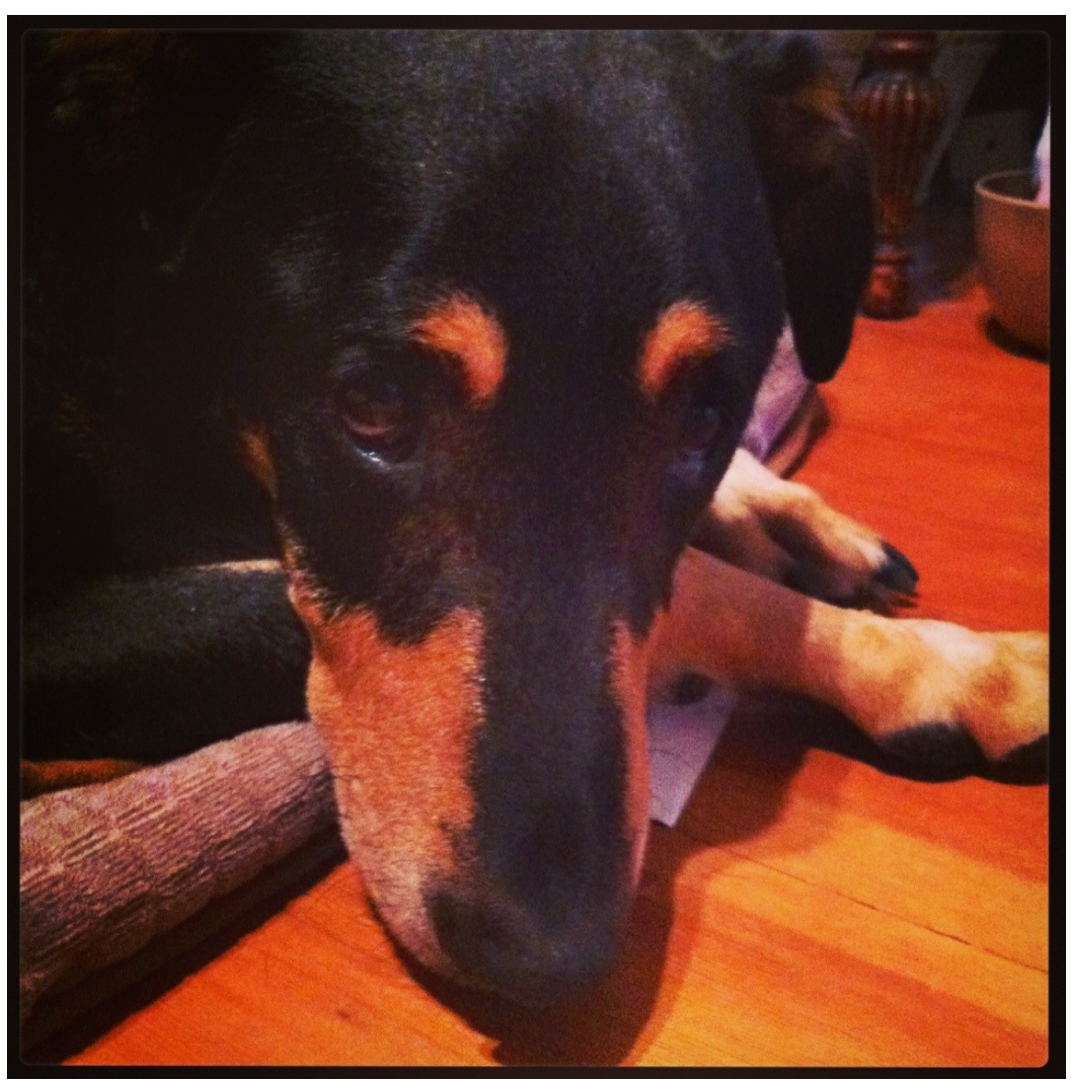




\section{Table of Contents}

ABSTRACT

DEDICATION iv

LIST OF TABLES viii

LIST OF FIGURES $x$

CHAPTER ONE: INTRODUCTION 1

CHAPTER TWO: INTRASPECIFIC VARIATION IN THERMOTOLERANCE AND MORPHOLOGY OF THE INVASIVE EUROPEAN GREEN CRAB, CARCINUS MAENAS, ON THE WEST COAST OF NORTH AMERICA .

Introduction.

Statistical Analysis.

Results

Discussion

Conclusions

CHAPTER THREE: COLD TOLERANCE OF THE INVASIVE CARCINUS MAENAS IN THE EAST PACIFIC: MOLECULAR MECHANISMS AND IMPLICATIONS FOR RANGE EXPANSION IN A CHANGING CLIMATE..........42 42

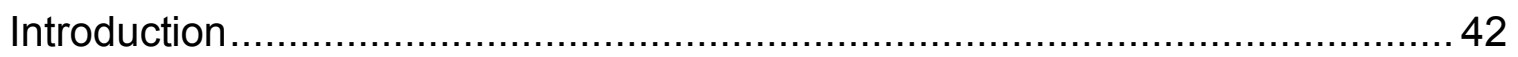

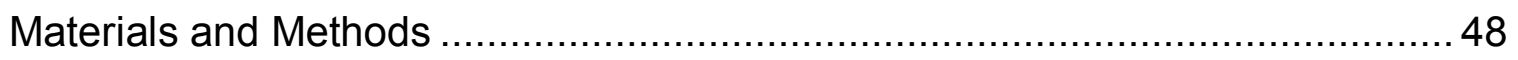

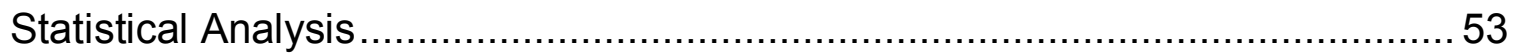


Results

Discussion

CHAPTER FOUR: BIOGEOGRAPHIC VARIATION IN BODY SIZE IN THE INVASIVE CARCINUS MAENAS ON THE WEST COAST OF NORTH AMERICA: DOES THE GREEN CRAB FOLLOW THE TEMPERATURE- SIZE

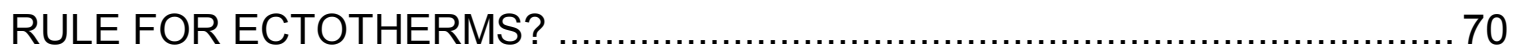

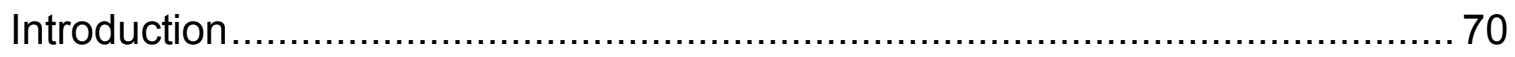

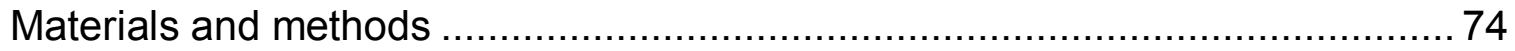

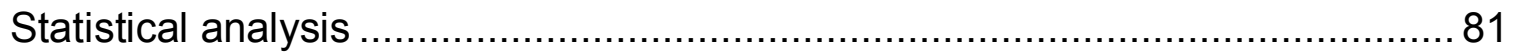

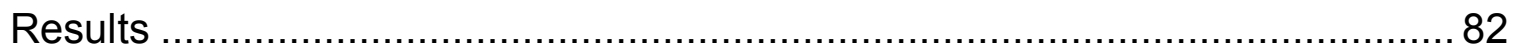

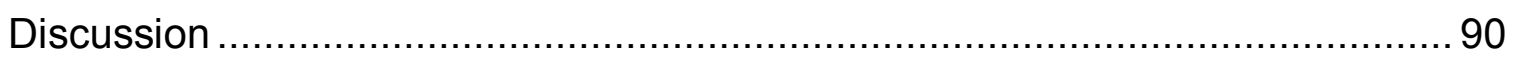

CHAPTER FIVE: PHYSIOLOGICAL CORRELATES OF SPECIES INVASION 100

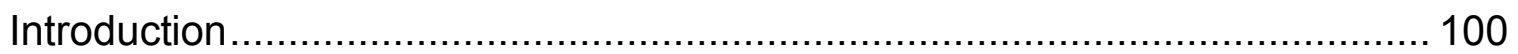

Methodological approaches to comparing physiological responses between

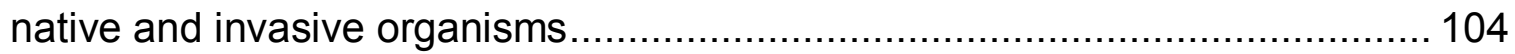

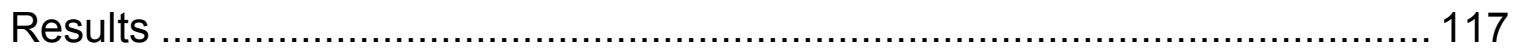

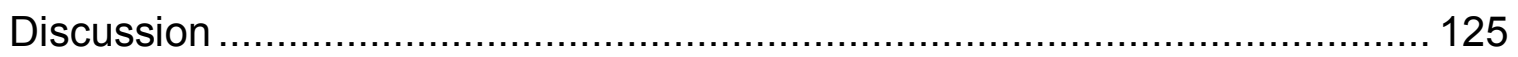

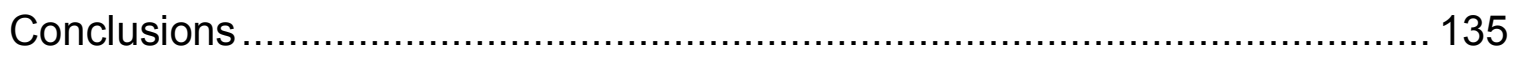

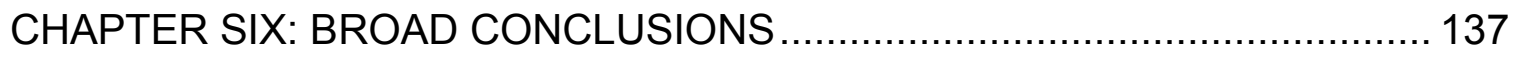


CHAPTER SEVEN: GLOBAL CHANGE BIOLOGY: MODELING THE PROCESS OF OCEAN ACIDIFICATION AS A FRAMEWORK FOR UNDERSTANDING THE EFFECTS OF GLOBAL CLIMATE CHANGE ON MARINE ORGANISMS ....... 140

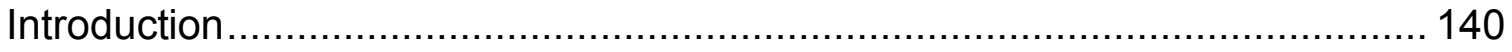

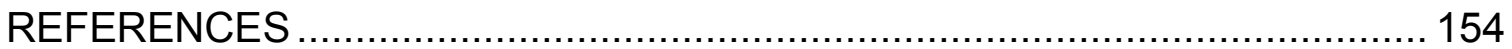

APPENDIX: C/EBP- $\triangle$ EXPRESSION IN INTERTIDAL ORGANISMS ............. 177 


\section{LIST OF TABLES}

Table 2.1 Published carapace widths for Carcinus maenas from different latitudes.

Table 3.1 GLM Analysis of variance for cyclin D1 protein expression. .............. 55

Table 3.2 Post-hoc comparisons of cyclin D1 protein expression...................... 57

Table 3.3 GLM Analysis of variance of Hsp70 protein expression..................... 59

Table 3.4 Post-hoc comparisons of Hsp70 protein expression......................... 59

Table 4.1 Lists the sample site, temperature logger type, crab sampling range, mean temperature, and reference for the temperature data........................... 76 Table 4.2 Literature review: lists sample site, latitude and longitude, sample size, sex, citation, and mean sea surface temperature ..................................... 81 Table 4.3 Lists mean, mean max, and maximum CW, sex, and sample size from

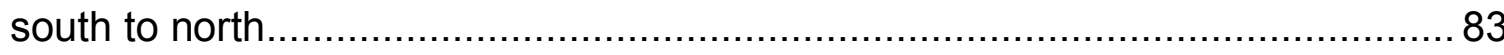

Table 4.4 Correlation regression for mean, mean max, and maximum $\mathrm{CW}$ and latitude, listing the $r$ value, and $95 \%$ confidence interval. ................................ 86

Table 4.5 correlation regression for mean, mean max, and maximum $\mathrm{CW}$ and temperature, listing the $r$ value, and $95 \%$ confidence interval. 88

Table 5.1 Lists the citation, species, taxon, high and low geographic thermal limits, origin- native or invasive, ramping rate, and LT50 value. 110 
Table 5.2 Lists the citation, species, origin- native or invasive, Hsp quantified, gene expression type, $t_{\text {on }}$ and $t_{\max }$, maximal expression, and associated statistical error.

Table 5.3 Lists the species, taxon, range (invasive or native) lower and upper acclimation temperature $\left({ }^{\circ} \mathrm{C}\right)$, the corresponding LT50 temperatures after acclimation to two temperatures $\left({ }^{\circ} \mathrm{C}\right), \Delta$ acclimation $\left({ }^{\circ} \mathrm{C}\right), \Delta \mathrm{LT} 50$, and the arr-

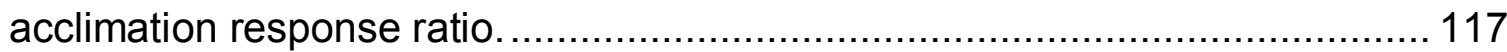




\section{LIST OF FIGURES}

Figure 2.1 The current distribution of Carcinus maenas on the west coast of

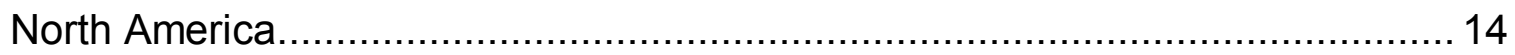

Figure 2.2 Mean CT max for Carcinus maenas after heat ramp...................... 25

Figure 2.3 Relative Hsp70 levels in chelae muscle of Carcinus maenas after whole animal heat ramp of $2^{\circ} \mathrm{C}$ per $0.5 \mathrm{hr}$ starting at the acclimation

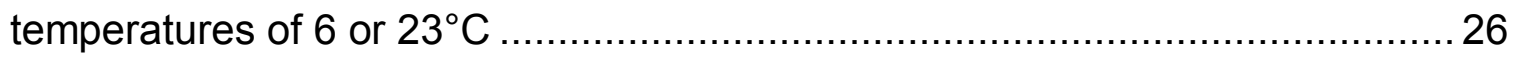

Figure 2.4 Relative levels of $\mathrm{Hsp} 70$ at $0,2 \mathrm{hr}$ and $4 \mathrm{hrs}$ at treatment temperatures of $6,12,18,24$, and $30^{\circ} \mathrm{C}$ in isolated tissue 28

Figure 2.5 An empirical cumulative distribution frequency of carapace widths from the California and British Columbia populations 30 Figure 2.6 Maximum reported male carapace width versus the latitude of each sample site from $C$. maenas native range. 37

Figure 3.1 The current distribution of Carcinus maenas on the west coast of North America, from Elkhorn Slough, California, to Gales Passage, British Columbia mainland and overwinter thermal profile site- Sitka, Alaska.

Figure 3.2 Over-winter thermal profile. generated from NOAA buoy data gathered from 2009 for Sitka, AK. 51

Figure 3.3 Cylin D1 protein levels in C. maenas. Relative levels of cyclin D1 at control sampling and after cold shock. 56 
Figure 3.4 Hsp70 levels in C. maenas. Relative levels of Hsp70 at control sampling and after cold shock. 58

Figure 3.5 Thermogeographic contour map of average sea surface temperatures from January through March 2009. 62

Figure 3.6 Thermogeographic contour map of average sea surface temperatures with $1.8^{\circ} \mathrm{C}$ added to the profile, reflecting projections of the IPCC SRES B2 scenario. 64

Figure 3.7 Relative control levels of cyclin 1 and Hsp70 68

Figure 4.1 The current distribution of Carcinus maenas on the west coast of North America. 74 Figure 4.2 Box plot for each sample site marking sample minimum, maximum and quartiles of $\mathrm{CW}$ 84 Figure 4.3 Scatterplot using mean, mean max, and maximum CW from each sample site and latitude $\left({ }^{\circ} \mathrm{N}\right)$ of sample site. 85 Figure 4.4 Scatterplot using mean, mean max, and maximum $\mathrm{CW}$ values from each sample site and temperature $\left({ }^{\circ} \mathrm{C}\right)$ of sample site 88 Figure 4.5 Linear regression of maximum reported male CW versus temperature $\left({ }^{\circ} \mathrm{C}\right)$ 89

Figure 4.6 Linear regression of mean temperature $\left({ }^{\circ} \mathrm{C}\right)$ of each sample site versus latitude $\left({ }^{\circ} \mathrm{N}\right)$ 90 
Figure 5.1 Linear regression illustrating the relationship between geographic thermal range (native and invasive) and the LT50 ...................................118 Figure 5.2 Linear regression illustrating the relationship between highest habitat temperature experienced and the LT50. 120

Figure 5.3 Maximal Hsp70 expression levels, hemiptera, tunicates, and macrophytes. 121

Figure 5.4 Maximal Hsp20 expression levels, hemiptera and bivalves. 122

Figure 5.5 Maximal Hsp90 expression levels, hemiptera 122

Figure 5.6 Acclimation response ratio- ARR of invasive species 123

Figure 5.7 Acclimation response ratio- ARR of native species. 124

Figure 7.1 Calcification reaction in sea water 145 


\section{CHAPTER ONE: INTRODUCTION}

In our increasingly modernized world, biological invasions of species that are non-native to a region are ever more common (Ruiz et al. 2000), escalating biological homogeneity in ecological communities worldwide (Cohen and Carlton 1998, Levine 2000). The effects of biological invasions are extensive, dramatically altering ecosystem function (Gordon 1998), and annually causing billions of dollars worth of economic damage within the United States alone (Pimentel et al. 2005). As a result, there is an increasing interest in predicting the spread of established bio-invaders. These predictions can inform strategies designed to minimize spread of invasive species, determine ideal monitoring sites for their early detection, and facilitate eradication efforts.

Abiotic resistance is a primary governing factor in determining the possible distribution of nonindigenous species within a recipient environment (Catford et al. 2009). Abiotic resistance occurs when non-native species fail to become established, even despite repeated propagule pressure, because they are maladapted to the local environment (Baltz 1993). The aptitude to cope with abiotic environmental stresses physiologically is important to an organism's ability to survive in a new, demanding environment. Temperature is often regarded as the most important environmental factor in determining the distribution of ectothermic species distribution due to its impact on biochemical and cellular processes (Somero 2002, 2005), which, in turn, can affect organismal performance (Tagatz 1971, Lewis and Roer 1988, Rome et al. 2005). 
Therefore, investigations exploring the effects of temperature on the physiology of species can provide a mechanistic understanding of the patterns and processes that accompany establishment, which can then be used to predict areas that may be susceptible to invasion.

Invasive species provide an experimental framework that allows us to develop and test both theoretical and applied hypotheses relating to invasion biology, ecology, evolution, biogeography, and phenotypic plasticity of organisms (Sax et al. 2005). We can also use invasive species to help us understand a range of ecological and physiological processes. For instance, invasive species can be used as a model to understand how environmental parameters can affect biological properties on multiple levels of biological organization, from cellular homeostasis to organismal performance to the biogeographic distribution of species across heterogeneous landscapes (Hochachka and Somero 2002, Somero 2002, Somero 2005).

This dissertation explores the thermal physiology of the invasive Carcinus maenas, the European green crab, along its invasive range on the west coast of North America. This work is the first of its kind for this species and endeavors to bring about a greater understanding of the physiological traits that this species has employed to become established in novel environments. The discoveries that this research produced has led us to further question whether these physiological properties are species-specific responses, or the physiologic traits utilized are widely observed among invasive species. 
Understanding the role of temperature in defining the distribution of invasive organisms can provide insights into the processes and patterns of species invasion. For the invasive decapod Carcinus maenas, temperature has been implicated as the main predictor of establishment success across temperate regions (Compton et al. 2010). Because of this, thermotolerance studies are paramount in defining the tolerable thermal ranges of this species. The invasive northwestern Pacific population of Carcinus maenas originated in San Francisco Bay, California (Cohen et al. 1995), and range expansion has been primarily northward, now extending to mainland British Columbia, Canada (Behrens-Yamada and Hunt 2000, Gillespie et al. 2007).

The first goal of this dissertation was to characterize the organismal and cellular response to heat shock, and to elucidate to what degree these responses differed between thermally disparate populations located near southern and northern range edges of this invasive population. We used established physiological assays to determine the upper organismal critical thermal maximum (CTmax) and heat shock protein 70 , Hsp70 synthesis of each population. This work has identified variations in the upper thermal tolerance thresholds of adult Carcinus maenas sampled from the northern, cold acclimated (Vancouver Island, British Columbia, Canada-BC) and southern, warm acclimated (Sea Drift Lagoon, California-CA) near the edges of their recipient range. Crabs sampled from BC had a significantly lower upper thermal tolerance (critical thermal maxima) and Hsp70 expression level after lab acclimation to $6^{\circ} \mathrm{C}$ when 
compared to the CA population after heat stress. These results highlight the ability of the BC population to down regulate its upper organismal and cellular thermotolerance to reflect the colder environment that it now inhabits, mirroring native ectotherms that have had millennia to undergo adaptive changes. For this species, it is probable that altering the scope of thermal tolerance, both organismal and cellular, after acclimation, is one physiologic process that has proved to be vital to invasion success.

A second goal of this dissertation was to assess the potential for range expansion using both organismal and cellular measurements. Range expansion for this metapopulation has been principally northward, moving into seasonally cooler waters, consequently implicating cold stress as an environmental variable that may potentially affect further poleward range expansion. In an effort to characterize the cold tolerance of this invasive population, cold tolerance capacity was determined in the laboratory by holding crabs sampled from Vancouver Island, British Columbia, Canada (likely propagule source) to overwintering thermal profile generated from Sitka, Alaska, USA. This research demonstrated that crabs sampled from BC experienced high ( 93\%) survivorship in this treatment, indicating that adult crabs are thermally capable of existing outside their current northern range limits. Additionally, we also investigated cellular response to cold stress using two functional categories of the cellular stress response. Using intraspecific comparisons between warm-acclimated CA and cold-acclimated BC animals, we measured the relative levels of cyclin D1 (a 
cell-cycle modulator) and Hsp70 (a molecular chaperone) in response to cold stress. The BC population significantly down regulated cyclin D1 protein expression after cold shock, while the CA population did not. Cyclin D1 has been widely investigated due to its role as a cell cycle modulator, and its ablation in breast cancer tissue has been shown to shut off proliferation in breast tumor cell lines (Yu et al. 2001). Hsp70 was not differentially regulated in response to cold stress.

The third aim focused on the effect of temperature on body size. The effect of temperature on body size in invertebrates, amphibians, reptiles and fish is referred to as the "temperature size rule for ectotherms" (Partridge and Fowler 1993, Sibly and Atkinson 1994). Given that the extremely low genetic diversity of the C. maenas metapopulation (Tepolt et al. 2009), we used this system as a model to explore how the thermal gradient present on the west coast affected adult body size in this species. An observable difference in body size was identified, with a clinal gradient in carapace width $(\mathrm{CW})$, reflecting the thermal gradient present on the west coast of North America. Crabs sampled across the invaded range show a size-temperature relationship with the larger morphology hailing from the northern portion of the range, and the smaller crabs from sites in California. A literature review was conducted of $\mathrm{CW}$ across latitude for populations sampled from their native range, in an effort to determine if size and temperature are correlated in their native range. These two variables were found to be correlated in the ancestral range, with the larger eco-morph being found in 
Northern Europe. These results support the temperature size rule, with $\mathrm{CW}$ from both the native and invasive ranges found to be significantly correlated with environmental temperature.

Characterizing physiological properties and processes that may facilitate invasion success can identify species that are likely to become established if introduced into novel environments. The final aim of this dissertation was to identify physiologic patterns that facilitate invasion success, and to assess whether these traits were widespread among other invasive ectotherms. The research presented here has correlated several physiological traits that may have played a role in establishment success for Carcinus maenas. Four hypotheses were generated from this work and tested using a review of literature to determine whether the hypotheses could be supported across taxonomically distinct invasive species, which would identify these traits as common among invaders. The four hypotheses are: 1) Broad geographic temperature tolerances (thermal width) confer a higher thermal threshold to invasive than native species, 2) The upper thermal extreme experienced in nature is correlated with upper thermal tolerance threshold, 3) Protein chaperone expression, a cellular mechanism underlying thermal tolerance threshold, is greater in invasive organisms than in native ones, and 4) Acclimation to higher temperatures can promote a greater range of thermal tolerance for invasives compared to natives. Using a meta-analytical approach, each one of these hypotheses was generally 
supported, providing further evidence of a major role for physiology in the invasion process.

\section{General considerations}

From an evolutionary perspective, invasive species are excellent model organisms to study because they arrive in their new environment with genomes that are the product of natural selection from another geographic region. The recipient environment selects for phenotypes that promote survival in this environment across two time scales. First, plastic phenotypic changes can occur within an individual's lifetime and these can be identified and measured at the organismal and cellular levels. Second, intergenerational adaptive changes can occur through the modification of genomic sequence, thereby altering physiological performance. While adaptive genetic changes may occur, it is likely that phenotypic plasticity is essential to the success of the initial invasion, as genes are being up and down regulated, synthesizing proteins that will directly aid the organism in maintaining cellular function. The ability to quantify these subtle cellular responses to environmental stressors could give great insight into an introduced species' ability to cope with abiotic stressors (Lonsdale 1999) and provide insight to those mechanisms that facilitate invasion success.

To date, there is little known about the physiology of Carcinus maenas from invasive populations. Determining the scope of thermal tolerance and preference at multiple levels of biological invasion will add to the growing body of work used to predict the spread of this established bio-invader. Making 
predictions of the potential distribution of non-native species is a first line of defense against expansion of invasive organisms to and within a recipient ecosystem. Such predictions inform monitoring that can give managers a chance to detect propagules early in the invasion process. Early detection is important because eradication methods have a greater probability of success when populations are new and relatively small (Hobbs and Humphries 1995).

\section{Carcinus maenas Ecology}

\section{Distribution}

The European green crab, Carcinus maenas, is native to the Atlantic Ocean from northern Africa to Europe, and has invaded many different regions globally (Carlton and Cohen 2003). Their distribution can now be described as cosmopolitan, being found on both coasts of North America, as well as in South America, South Africa, and Australia (Carlton 2003, Thresher 2003). This brachyuran crab has the capacity to reduce native populations of shellfish and invertebrates, which have been documented as prey items for native crabs and birds (Ropes 1968, Grosholz 1995, Grosholz 2000, Walton 2003). This top down predatory effect can alter ecosystem function, creating undesirable conditions for native organisms (Walton et al. 2002).

Carcinus maenas is both eurythermal and euryhaline, inhabiting intertidal and subtidal zones, rocky coasts to soft bottom estuaries, embayments, and marshes in its home and recipient ranges (Cohen et al. 1995). Its vertical distribution stretches from the intertidal to $60 \mathrm{~m}$ (Crothers 1968). Adult crabs can 
be found in salinities ranging from 10 to $33 \mathrm{ppt}$, but have been identified in brackish water areas with salinity values as low as 1.4 ppt (Broekhuysen 1936, Crothers 1968, Perkins E.J. E. Gribbon 1969), however invasion into fresh water has not been noted. In the field, this species can tolerate temperatures from $1^{\circ} \mathrm{C}$ to $22^{\circ} \mathrm{C}$ (Cohen et al. 1995). It should be understood that non-native populations' salinity and temperature tolerances have not been directly determined in the laboratory.

\section{Reproduction and Development}

Reproductive cycles and molting tend to be in phase with warmer temperatures, but can occur year round in warmer geographic areas (Broekhuysen 1936). Copulation takes place after molting, when the female is soft (Broekhuysen 1936), and egg masses appear between 1-4.5 months after copulation (Broekhuysen 1936). Larval release is limited to spring, summer, and fall, and larval development slows or ceases in cold winter months (Broekhuysen 1936, Crothers 1968). The estimated lifespan of an individual is between 3-6 years, depending on its geographic location (Berrill 1982).

Larval development in Carcinus maenas is as follows: zoeal stages ZI-ZIV, megalopa, two crab instar phases, juvenile, and then finally, the adult stage. The ZI stage is better able to acclimate to thermal and salinity variations than the ZIIZIV and megalopa stage (Nagaraj 1993, Cieluch et al. 2004).

Diet 
The European green crab is a voracious predator, known to prey on at least 104 families and 158 genera in 5 plant and protist and 14 animal phyla (Cohen et al 1995). However, the major prey items are bivalves, crustaceans, and polychaetes (Cohen et al. 1995). Their ability to prey on such a wide variety of taxa likely influences their broad distribution (Cohen et al. 1995). This species is thought to be a chemosensory and tactile hunter as opposed to a visual hunter (Crothers 1968, Ropes 1968, Hadlock 1980). 


\section{CHAPTER TWO: INTRASPECIFIC VARIATION IN THERMOTOLERANCE AND MORPHOLOGY OF THE INVASIVE EUROPEAN GREEN CRAB, CARCINUS MAENAS, ON THE WEST COAST OF NORTH AMERICA}

\section{Introduction}

The emerging field of macrophysiology involves measuring variation in physiological traits over broad spatial and temporal scales in an effort to investigate the ecological impacts of these traits (Chown et al. 2004). In particular, the application of established ecophysiological approaches across broad geographic scales in the marine environment has been highlighted as a useful means to aid in predicting how species or communities will respond to climate change (Pörtner et al. 2001, Helmuth et al. 2002, Kennedy et al. 2002, Parmesan and Yohe 2003, Stillman 2003, Baker et al. 2004, Hassol 2004, Helmuth et al. 2005, Harley et al. 2006, Parmesan 2006). Similar approaches can also be helpful in understanding how the distribution and abundance of marine invasive species are impacted by abiotic factors in the environment (Harris and Tyrrell 2001, Grosholz 2002). Of these factors, temperature is among the most influential for marine ectotherms, as it affects nearly all biological systems at all levels of organization from organismal fitness to cellular homeostasis (Pörtner 2002b, Somero 2002). It is now understood that organisms that inhabit different thermal habitats may exhibit disparate thermal tolerance limits and optima, reflecting the temperature of their natural environment (Somero 2002). 
The current study focuses on the thermal physiology of the European green crab, Carcinus maenas, which is native to the northeast Atlantic and has invaded multiple marine bioregions. This eurythermal crab has been successful at many latitudes as well as across bioregions. It inhabits waters where temperatures reach $23^{\circ} \mathrm{C}$ to sub-polar regions where temperatures drop to $1.0^{\circ} \mathrm{C}$ (Cohen et al. 1995). Therefore, thermal tolerances may differ between populations. It is unclear however, whether juvenile and adult green crabs can tolerate the extremes of this potential thermal window, as data are generally lacking on the effects of local adaptation on lethal thermal thresholds and the effect of temperature on basic physiological processes across its native and invaded ranges. On the west coast of North America, the focus of this study, its range currently spans 12 degrees of latitude, extending from Elkhorn Slough, California (CA), USA (personal observation) to Quatsino, Vancouver Island, British Columbia (BC), Canada (Gillespie et al. 2007) (Fig. 2.1). Ambient sea surface temperature in the northern part of the North American west coast range is 5 to $10^{\circ} \mathrm{C}$ lower, depending on the time of year, than near the southern range limit (http://www.osdpd.noaa.gov/ml/ocean/sst/contour.html).

The invasion to the west coast of North America is relatively recent and intra-regional spread to areas with different thermal regimes has been rapid. Discovered in San Francisco Bay, CA in 1989 (Cohen et al., 1995), this brachyuran species quickly moved northward, establishing self-sustaining populations in Oregon by 1996 (Behrens Yamada and Hunt 2000). A strong El 
Niño event during the winter of 1997/1998 facilitated dispersal of C. maenas larvae to Washington and up the west coast of Vancouver Island (Behrens Yamada and Hunt, 2000; Gillespie et al., 2007) and by 2000, this species had established viable populations in embayments along a $1200-\mathrm{km}$ portion of the northeastern Pacific coastline. During summer months, the southern population can routinely experience temperatures at or near $23^{\circ} \mathrm{C}$ while minimum winter temperatures decline to $\sim 11^{\circ} \mathrm{C}$ (http://cdmo.baruch.sc.edu). Conversely, the northern population has been found in waters as cold as $6^{\circ} \mathrm{C}$ during the winter and as warm as $\sim 14^{\circ} \mathrm{C}$ during the summer (http://www-sci.pac.dfompo.gc.ca/osap/data). 


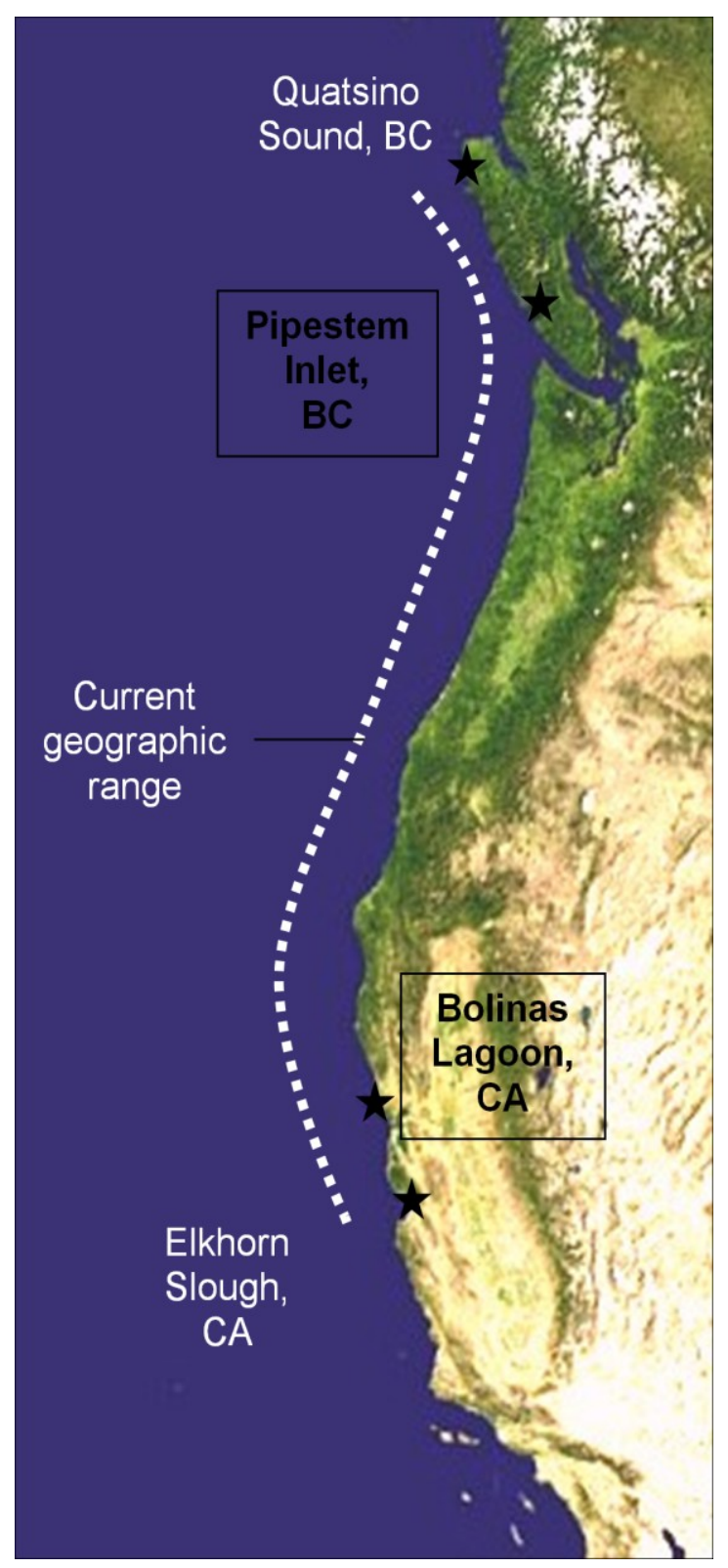

FIGURE 2.1 THE CURRENT DISTRIBUTION OF CARCINUS MAENAS ON THE WEST COAST OF NORTH AMERICA. MARKED ARE THE SAMPLE SITES FOR THIS STUDY, PIPESTEM INLET, BRITISH COLUMBIA, CANADA, AND SEADRIFT LAGOON, STINSON BEACH, CALIFORNIA, USA, AS WELL AS THE PRESENT KNOWN RANGE.

Despite the relatively short, $\sim 20$-year invasion history of the Northeast Pacific metapopulation of C. maenas, the disparate thermal environments experienced by the northern versus southern population may be sufficient to give 
rise to site-specific physiological phenotypes for each population. However, population genetic studies using microsatellites demonstrated that the genetic diversity of this population is extremely low compared to other native and invasive populations, with only a single representative haplotype being detected (Darling et al. 2008). Furthermore, the founding population in San Francisco Bay likely germinated from no more than 48 individuals (Tepolt et al. 2009). In studies on fishes, it has been demonstrated that congeners sampled from different thermal habitats that were acclimated to a common temperature exhibit thermotolerances that reflect their native thermal environment (Hart 1952, McCauley 1958, Fields et al. 1987, Lohr et al. 1996, Strange et al. 2002). Similar studies comparing genetically connected populations of marine ectotherms are scarce. In order to identify any variation in thermotolerance of the North American west coast C. maenas meta-population, populations from near the northern and southern edges of their recipient range were collected and their organismal upper thermotolerance thresholds (ie. critical thermal maximum [CTmax]) were measured. Given the difference between the local habitat temperatures these populations experience in situ, our a priori expectation was that the BC crabs would elicit a lower CTmax, regardless of acclimation treatment, when compared to the CA population.

Intra- and inter-specific variation in thermolerance can also be assessed at the cellular level. One commonly used metric for evaluating the effects of temperature on cellular function is the measurement of the induction thresholds 
of the heat shock response (HSR) (Feder and Hofmann 1999, Somero 2002). The HSR is a highly conserved process by which a family of stress proteins called heat shock proteins (Hsps) are induced and synthesized during bouts of exposure to heat (Lindquist 1986) and other proteotoxic stressors. These stressors include hypoxia, osmotic stress, infection, heavy metal exposure and ultraviolet light (Feder and Hofmann 1999, Fink 1999). Hsps are protein chaperones that protect and repair abnormally denatured proteins (Fink, 1999) and the genes that encode them have been shown to be likely candidates of adaptive evolution to temperature (Somero 2005). Here, we compared levels and induction thresholds of Hsp70, the most commonly and dramatically induced Hsp isoform, in green crabs from the $\mathrm{CA}$ and $\mathrm{BC}$ populations

Temperature as a selecting agent has the capacity to affect change in many phenotypic traits, including adult body size (Lonsdale and Levinton 1985, Atkinson 1994, Suzuki and Nijhout 2006). For instance, Atkinson (1994) found that a decrease in rearing temperature resulted in an increase in adult body size for $80 \%$ of ectotherm species in 109 studies examined (Atkinson 1994). This type of body size patterning across a latitudinal cline has been noted in the marine copepod Scottolana domestica (Lonsdale and Levinton, 1985), as well as the purple sea urchin, Strongylocentrotus purpuratus (Osovitz and Hofmann 2005) and Drosophila (Coyne and Beecham 1987). Temperature has been postulated to influence body size in marine ectotherms in at least two ways. First, the influence of environmental temperature may produce evolutionary changes in the 
genes governing the physiological mechanisms that dictate metabolism, growth rate and adult size. Second, differences in the temperature to which individuals sharing the same genotype are exposed during development can cause polyphenism, which in turn may influence final adult size (Partridge and French 1996). For this study, the latter hypothesis is the most suitable given our state of knowledge concerning the genetic variation of this particular invasive population. Polyphenisms can arise by exposure to an environmental cue that directs an organism down an alternate developmental trajectory. The threshold for the switch between alternative character states may vary in response to external selective pressures. Variations in overall size of Carcinus maenas were investigated, and differences in morphology were detected between populations, with the northern population having significantly larger mean carapace width than those sampled from the southern population.

The overarching goals of this study were to use physiological matrices and morphometrics to investigate whether phenotypic divergence has occurred between two populations of this highly successful invasive species at the edges of its range on the west coast of North America and to determine whether this divergence reflects the thermal conditions of their respective habitats. Specifically, we tested the hypothesis that the northern and southern populations differ in their thermotolerance. The primary questions of the current study were: (1) Are there differences in thermotolerance between these populations observable at the level of the whole organism? (2) Are there detectable 
differences in the induction threshold and magnitude of expression of Hsp70 between populations? (3) Are these physiological responses fixed or are they responsive to acclimation? (4) Are there observable differences in morphological characteristics that may be influenced by temperature?

\section{Materials and Methods}

\section{Specimen collection and maintenance}

Adult male and female Carcinus maenas were collected from subtidal locations at two sites, Seadrift Lagoon, California, USA $\left(37^{\circ} 54^{\prime} 27.82^{\prime \prime} \mathrm{N}\right.$, $122^{\circ} 40^{\prime} 19.56 \mathrm{WW}$ ) and Pipestem Inlet, Vancouver Island, British Columbia, Canada $\left(49^{\circ} 02.3^{\prime} \mathrm{N}, 125^{\circ} 12.2^{\prime} \mathrm{W}\right)$. These sites had large populations, were near the range edges, and had steep intertidal zones that minimized the likelihood that the specimens would have experienced large thermal shifts from changes in air temperature in the exposed intertidal. Adult intermolt specimens were collected via folding Fukui fish traps (63 $\times 46 \times 23 \mathrm{~cm} ; 1.6 \mathrm{~cm}$ mesh) from subtidal locations at the two sites in 2008 and 2009, then crabs were transported in aerated coolers to Portland State University. Transit time took no more than 24 hours. Animals were immediately laboratory-acclimated for four weeks at $12^{\circ} \mathrm{C}$. After acclimation to laboratory conditions, crabs from both populations were split into two groups ( $\mathrm{n}=15$ each group) and acclimated to either $6^{\circ} \mathrm{C}$ or $23^{\circ} \mathrm{C}$ for six weeks prior to use in experiments. These acclimation temperatures were chosen because they reflect the extreme low and high temperatures experienced by this meta-population at its present northern and southern range limits, respectively. 
During the laboratory and experimental acclimation periods, each population and treatment group (4 total) were held in recirculating, temperature-controlled aquaria in artificial sea water (Instant Ocean) at $34 \mathrm{ppt}$, with weekly water changes, and fed the mussel Mytilus trossulus ad libitum once a week. Temperatures were held within $\pm 1^{\circ} \mathrm{C}$ of the target temperatures for both temperatures.

\section{Measurement of organismal thermal tolerance limits}

Upper critical thermal maximum (CTmax) for both populations at both experimental acclimation temperatures were identified using a protocol adapted from Stillman and Somero (2000) (Stillman and Somero 2000). Crabs (sampled in 2008), were held in an insulated cooler heated by a recirculating water heater (Lauda Econoline RE-106, Delran, NJ). Starting at the acclimation temperature of either 6 or $23^{\circ} \mathrm{C}$, water temperature was increased at a rate of $2^{\circ} \mathrm{C}$ every $30 \mathrm{~min}$. This heat ramping rate avoided immediate acute heat shock of experimental animals, yet allowed the experiment to be concluded within the course of a day. The water bath was aerated during heat ramping and water temperature was constantly monitored with a dual thermometer (VWR, West Chester, PA). The CTmax was established for each individual by recording the temperature and time at which death occurred. All organisms elicited a similar behavioral response to increasing temperature, which was characterized by initial hyperactivity, then muscular spasms, followed by a lack of movement, and finally a relaxed, open abdomen. The ultimate metric of death for this assay was the 
termination of respiration, as noted by lack of observable movement of seawater being drawn through the carapace due to cessation of movement of the scaphognathite (the mechanism by which C. maenas actively respires (Crothers, 1968). Muscle tissue samples were taken from the chelae of each individual at the time of death, flash frozen in liquid $\mathrm{N}_{2}$, and stored in a $-80^{\circ} \mathrm{C}$ freezer for later molecular analysis.

Quantification of Hsp70 concentration via immunohistochemistry (western blotting)

We examined whether whole animal thermal tolerance response was also reflected in Hsp70 expression. The chelae tissue samples from the CTmax assay were used for quantification of Hsp70 synthesized during the organismal thermotolerance experiment. Tissue samples were homogenized in lysis buffer $\left(32 \mathrm{mmol}^{-1}\right.$ Tris- $\mathrm{Cl}, \mathrm{pH} 6.8,0.2 \%$ sodium dodecyl sulfide [SDS]), boiled for $5 \mathrm{~min}$ at $100^{\circ} \mathrm{C}$, and then centrifuged at $12,000 \times \mathrm{g}$ at room temperature. Supernatants were collected for use in the following analyses. Protein concentrations were determined by Bradford assay (Pierce Rockford, IL, USA). Ten $\mu g$ of total protein were separated via SDS polyacrylamide gel electrophoresis on $10 \%$ polyacrylamide gels and transferred to nitrocellulose membranes via overnight electrotransfer at $30 \mathrm{~V}$. Blots were incubated in an anti-Hsp70 rabbit polyclonal IgG antibody (Santa Cruz Biotechnology, Santa Cruz, CA, USA), at a 1:1000 dilution in $5 \%$ nonfat dried milk in 1 x PBS, for $1.5 \mathrm{~h}$ on a shaker, at room temperature. The blots were then incubated in a horseradish peroxidase (HRP)- 
conjugated goat anti-rabbit secondary antibody (Thermo Scientific, Pittsburg, PA, USA) at a 1:5000 dilution for $1 \mathrm{~h}$. Blots were visualized via enhanced chemiluminescence (SuperSignal reagent; Pierce, Rockford, IL, USA) followed by exposure to X-ray film (Kodak X-OMAT AR; Sigma) and densitometry was performed using ImageJ freeware.

The effect of heat shock on Hsp70 production in isolated tissue

To test whether cold-acclimated crabs from the BC population were able to induce an Hsp response to increasing temperatures similar to the CA group, we examined Hsp levels in tissues of crabs from both populations. Crabs for this assay were sampled in 2009. After whole animal acclimation at $6^{\circ} \mathrm{C}$ for six weeks, chelae muscle tissue was taken from five individuals from each population. Tissue from each crab was subdivided into 15 samples (one for every temperature-time combination). These isolated tissue samples $(0.1 \mathrm{~g} /$ sample), suspended in green crab Ringer's solution $(525 \mathrm{mM} \mathrm{NaCl}, 13.27 \mathrm{mM} \mathrm{KCl}, 12.39$ $\mathrm{mM} \mathrm{CaCl} 2,24.78 \mathrm{mM} \mathrm{MgCl}_{2}$ ), were held at $6,12,18,24$, and $30^{\circ} \mathrm{C}$ in water baths (Isotemp 210, Fisher Scientific, Pittsburg, PA, USA) in $1.5 \mathrm{ml}$ centrifuge tubes. Tissue was sampled at $0,2 \mathrm{hr}$, and $4 \mathrm{hr}$ and flash frozen in liquid $\mathrm{N}_{2}$. Total Hsp70 was quantified via western blot, using the same protocol described above.

\section{Morphometric measurements}

Morphometric measurements were taken for all adult crabs used in the thermotolerance experiments, as well as other individuals, not used in experiments, from the same sample sites. The carapace width $(\mathrm{CW})$ at the 
widest point ( $5^{\text {th }}$ spine on either side of the carapace) was measured to the nearest $1 \mathrm{~mm}$ with Vernier calipers. Body mass and sex were also recorded. The morphometric dataset included crabs that were sampled from CA on August 26, 2008 and July 12, 2009, and from BC on September 28, 2008 and March 24, 2009.

\section{Literature review of carapace width}

To discern whether the clinal variation in $\mathrm{CW}$ seen in this invasive range of green crabs was also present in the ancestral lineage, we conducted a literature review of CW across latitude for populations sampled in their native range (Table 2.1). The criteria for inclusion in this literature review were identifying a range of CW sampled, allowing us to identify the largest organism sampled, and noting the location of the sampling site. In order to reduce the likelihood of biased sampling, multiple CW samples were recorded from each latitude.

\begin{tabular}{|c|c|c|c|c|c|}
\hline Latitude & $\begin{array}{c}\text { Site and date } \\
\text { collected }\end{array}$ & $\begin{array}{c}\text { Sample } \\
\text { size }\end{array}$ & Sex & $\begin{array}{c}\text { Frequency } \\
\text { of CW- mm }\end{array}$ & Citation \\
\hline 51 & $\begin{array}{c}\text { Dale Roads, } \\
\text { Wales, UK, 1964- } \\
\text { 1966 }\end{array}$ & 1615 & Male+Female & $20-70$ & $\begin{array}{c}\text { (Crothers } \\
1968 \mathrm{~b})\end{array}$ \\
\hline 60 & $\begin{array}{c}\text { Island of Herdla, } \\
\text { west Norway, 1985 }\end{array}$ & 522 & Male & $20-80$ & $\begin{array}{c}\text { (Sekkelsten } \\
\text { 1988) }\end{array}$ \\
\hline 60 & $\begin{array}{c}\text { Island of Herdla, } \\
\text { west Norway, } \\
\text { 1984-85 }\end{array}$ & 880 & Male & $20->80$ & $\begin{array}{c}\text { (Van Der } \\
\text { Meeren 1994) }\end{array}$ \\
\hline 55 & $\begin{array}{c}\text { Millport, Isle of } \\
\text { Cumbra, 1996 }\end{array}$ & 64 & Male & $55-80$ & $\begin{array}{c}\text { (Sneddon et al. } \\
1997)\end{array}$ \\
\hline 50 & $\begin{array}{c}\text { Mountbatten, } \\
\text { Plymouth, UK, } \\
\text { 2005 }\end{array}$ & 80 & Male+Female & $42-65$ & $\begin{array}{c}\text { (Spooner et al. } \\
\text { 2007) }\end{array}$ \\
\hline 53 & $\begin{array}{c}\text { Anglesey, North } \\
\text { Wales, UK, <1978 }\end{array}$ & $\begin{array}{c}\text { Not } \\
\text { reported }\end{array}$ & Male & $60-75$ & (Elner 1978) \\
\hline 53 & $\begin{array}{c}\text { Dutch Wadden } \\
\text { Sea, 1963-64 }\end{array}$ & $>1000$ & Male & $15-70$ & $\begin{array}{c}\text { (Creutzberg } \\
\text { and Fonds }\end{array}$ \\
\hline
\end{tabular}




\begin{tabular}{|c|c|c|c|c|c|}
\hline & & & & & 1971) \\
\hline 53 & $\begin{array}{l}\text { Menai Strait, } \\
\text { Wales, <1987 }\end{array}$ & $>40$ & $\begin{array}{l}\text { Male and } \\
\text { Female }\end{array}$ & $50-70$ & $\begin{array}{c}\text { (Ameyaw- } \\
\text { Akumfi and } \\
\text { Hughes 1987) }\end{array}$ \\
\hline 54 & $\begin{array}{l}\text { Whitby Harbour } \\
\text { and Robin Hoods } \\
\text { Bay, UK, } 1973\end{array}$ & $>500$ & Male & $8-79$ & $\begin{array}{l}\text { (McVean } \\
1976)\end{array}$ \\
\hline 53 & $\begin{array}{c}\text { German Wadden } \\
\text { Sea, }<1998\end{array}$ & 9000 & Male & $15-71$ & (Wolf 1998) \\
\hline 55 & $\begin{array}{c}\text { Millport, Scotland, } \\
<1970\end{array}$ & 70 & $\begin{array}{l}\text { Male and } \\
\text { Female }\end{array}$ & $55-80$ & $\begin{array}{c}\text { (Heath and } \\
\text { Barnes 1970) }\end{array}$ \\
\hline 53 & $\begin{array}{c}\text { Menai Strait, UK, } \\
<1979\end{array}$ & 74 & Male & $60-70$ & $\begin{array}{c}\text { (Elner and } \\
\text { Hughes 1978) }\end{array}$ \\
\hline 53 & $\begin{array}{l}\text { Llandudno and } \\
\text { Conway, North } \\
\text { Wales, UK, 1965- } \\
67\end{array}$ & 75 & Male & $15-75$ & $\begin{array}{l}\text { (Walne and } \\
\text { Dean 1972) }\end{array}$ \\
\hline 50 & $\begin{array}{c}\text { Portwrinkle- } \\
\text { Thurlestone, UK, } \\
<2010\end{array}$ & 830 & Male & $18-70$ & $\begin{array}{l}\text { (Silva et al. } \\
\text { 2010) }\end{array}$ \\
\hline 51 & Essex, UK, <1931 & 22 & Male & $53-62$ & $\begin{array}{c}\text { (Huxley and } \\
\text { Richards 1931) }\end{array}$ \\
\hline 50 & $\begin{array}{c}\text { Plymouth, UK, } \\
<1931\end{array}$ & 270 & Male & $4-57$ & $\begin{array}{c}\text { (Huxley and } \\
\text { Richards 1931) }\end{array}$ \\
\hline 51 & $\begin{array}{c}\text { Oosterschelde, } \\
\text { Netherlands, } 2003\end{array}$ & 9 & Male & $44-63$ & $\begin{array}{l}\text { (Kamermans } \\
\text { et al. 2009) }\end{array}$ \\
\hline 54 & $\begin{array}{l}\text { Boggle Hole, UK, } \\
<2009\end{array}$ & 100 & Male & $65-75$ & $\begin{array}{c}\text { (Fletcher and } \\
\text { Hardege 2009) }\end{array}$ \\
\hline 58 & $\begin{array}{l}\text { Gullmarsfjorden, } \\
\text { Sweden, } \\
1997,1999,2000\end{array}$ & 9244 & Male & $24-75$ & (Werner 2001) \\
\hline 56 & $\begin{array}{c}\text { Odense Fjord, } \\
\text { Denmark, <1994 }\end{array}$ & $\begin{array}{c}\text { Not } \\
\text { reported }\end{array}$ & $\begin{array}{l}\text { Male and } \\
\text { Female }\end{array}$ & $60-80$ & $\begin{array}{l}\text { (Pedersen et } \\
\text { al. 1994) }\end{array}$ \\
\hline 55 & $\begin{array}{c}\text { Orensund, } \\
\text { Denmark, }<2004\end{array}$ & $<10$ & $\begin{array}{l}\text { Male and } \\
\text { Female }\end{array}$ & $50-80$ & (Garm 2005) \\
\hline
\end{tabular}

TABLE 2. 1 PUBLISHED CARAPACE WIDTHS FOR CARCINUS MAENAS FROM DIFFERENT LATITUDES.

\section{Statistical Analysis}

All statistical analyses were conducted using Minitab 15. Student's t-Tests were used to compare whole organism CTmax values as well as Hsp70 expression between populations for each acclimation treatment temperature. A fully factorial ANOVA was performed analyzing the individual and interacting 
effects of site, temperature, and sample timepoint in the Hsp70 isolated tissue experiment. A Mann-Whitney test was employed to compare carapace widths between populations in the morphometric analysis because the data did not meet the assumptions required for ANOVA.

\section{Results}

\section{Upper thermal tolerance limits in C. maenas}

The upper thermal critical maximum was higher for the Californian (CA) population than the British Columbian (BC) one whether they had been acclimated to $6^{\circ} \mathrm{C}$ or $23^{\circ} \mathrm{C}$. The $6^{\circ} \mathrm{C}$-acclimated CA group $(n=15)$ had a mean CTmax of $34.7^{\circ} \mathrm{C}$, whereas the CTmax for the $6^{\circ} \mathrm{C}$-acclimated $\mathrm{BC}$ group $(n=15)$ was $31.7^{\circ} \mathrm{C}$ (Fig. 2.2), a stastically significant difference (t-Test, $p=0.0018$ ). Similarly, the $23^{\circ} \mathrm{C}$-acclimated CA group exhibited a mean CTmax of $36.2^{\circ} \mathrm{C}$, while the CTmax of the $23^{\circ} \mathrm{C}$-acclimated $\mathrm{BC}$ group was $35.5^{\circ} \mathrm{C}(\mathrm{t}-\mathrm{Test}, \mathrm{p}=0.045)$. Both results support our a priori prediction. 


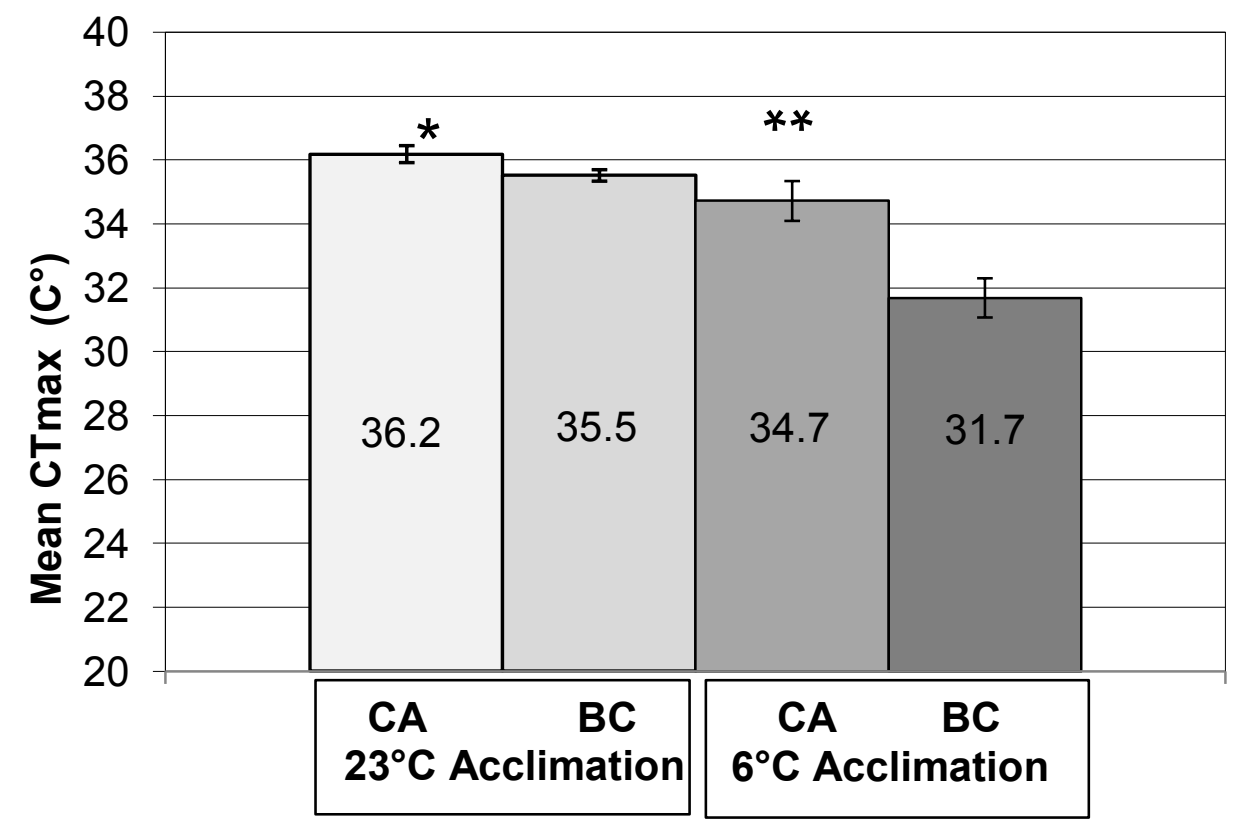

FIGURE 2.2 MEAN CT MAX FOR CARCINUS MAENAS AFTER WHOLE ANIMAL HEAT RAMP AT A RATE OF $2^{\circ} \mathrm{C}$ PER 0.5 HR STARTING AT THE ACCLIMATION TEMPERATURES OF 6 OR $23^{\circ} \mathrm{C}$. ERROR BARS REPRESENT STANDARD ERROR ( $\mathrm{N}=15$ PER TREATMENT GROUP). * $\mathrm{P}<0.045$ AND ${ }^{* *} \mathrm{P}=0.001, \mathrm{~T}-\mathrm{TEST}$.

\section{Quantification of Hsp70 synthesized during CTmax assay}

Hsp70 levels after heat ramping were significantly higher (t-Test, $\mathrm{p}=0.0018)$ in the $6^{\circ} \mathrm{C}$-acclimated $\mathrm{CA}$ group than the $6^{\circ} \mathrm{C}$-acclimated group from BC (Fig. 2.3). There was no significant difference in Hsp70 levels between the $23^{\circ} \mathrm{C}$ acclimated groups. 


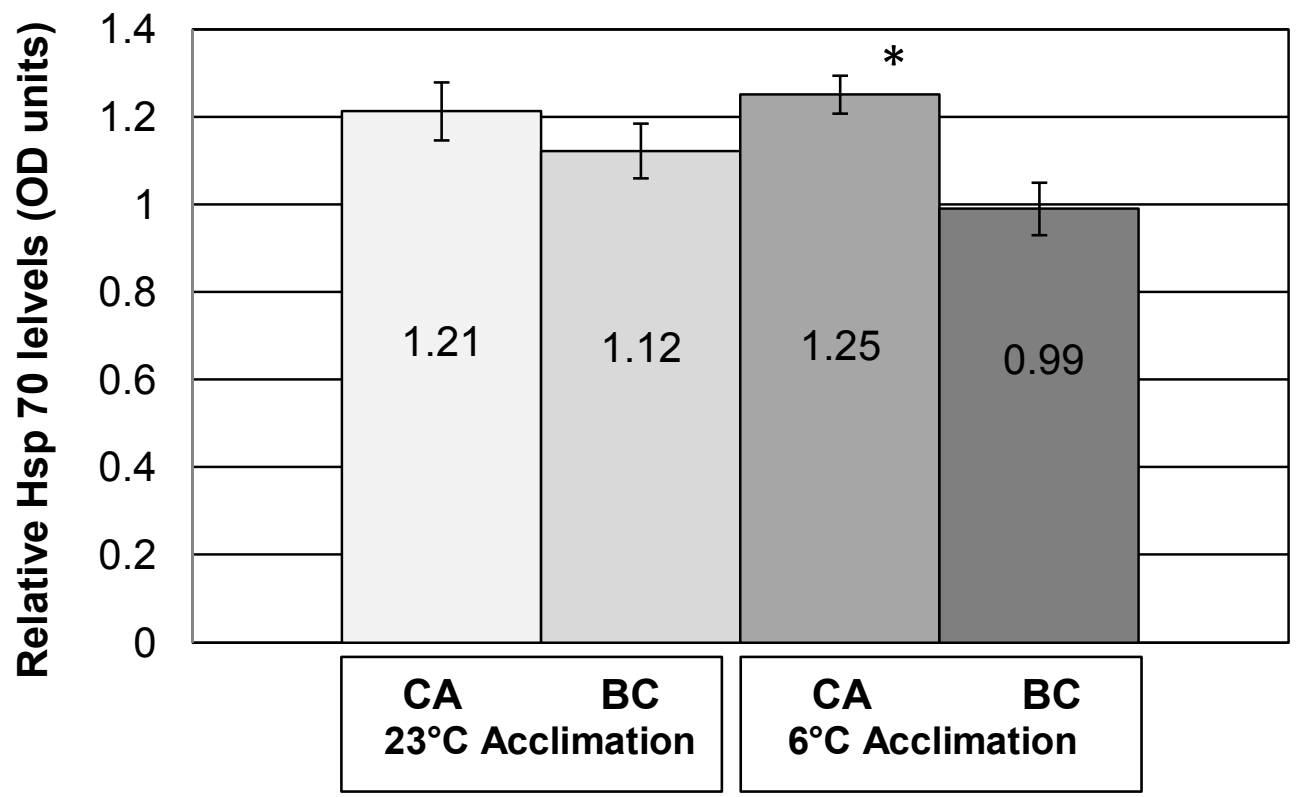

FIGURE 2.3 RELATIVE HSP70 LEVELS IN CHELAE MUSCLE OF CARCINUS MAENAS AFTER WHOLE ANIMAL HEAT RAMP OF $2^{\circ} \mathrm{C}$ PER 0.5 HR STARTING AT THE ACCLIMATION TEMPERATURES OF 6 OR $23^{\circ} \mathrm{C}$. ERROR BARS REPRESENT STANDARD ERROR. ${ }^{* *}=$ SIGNIFICANT DIFFERENCE BETWEEN CA AND BC, $\mathrm{P}=0.0018$.

\section{Quantification of Hsp70 synthesized at a suite of temperatures}

An ANOVA testing the interacting effects of sample site (CA or $B C)$, treatment temperature, and sample timepoint on the expression of Hsp70 found a significant effect of sample site $(p=0.003$; Fig 2.4 A,B). No effect of temperature or timepoint was found ( $p>0.05)$, although for both populations and time points Hsp70 expression peaked at $24^{\circ} \mathrm{C}$ then decreased at $30^{\circ} \mathrm{C}$, and none of the interactions was significant $(p>0.05)$. 


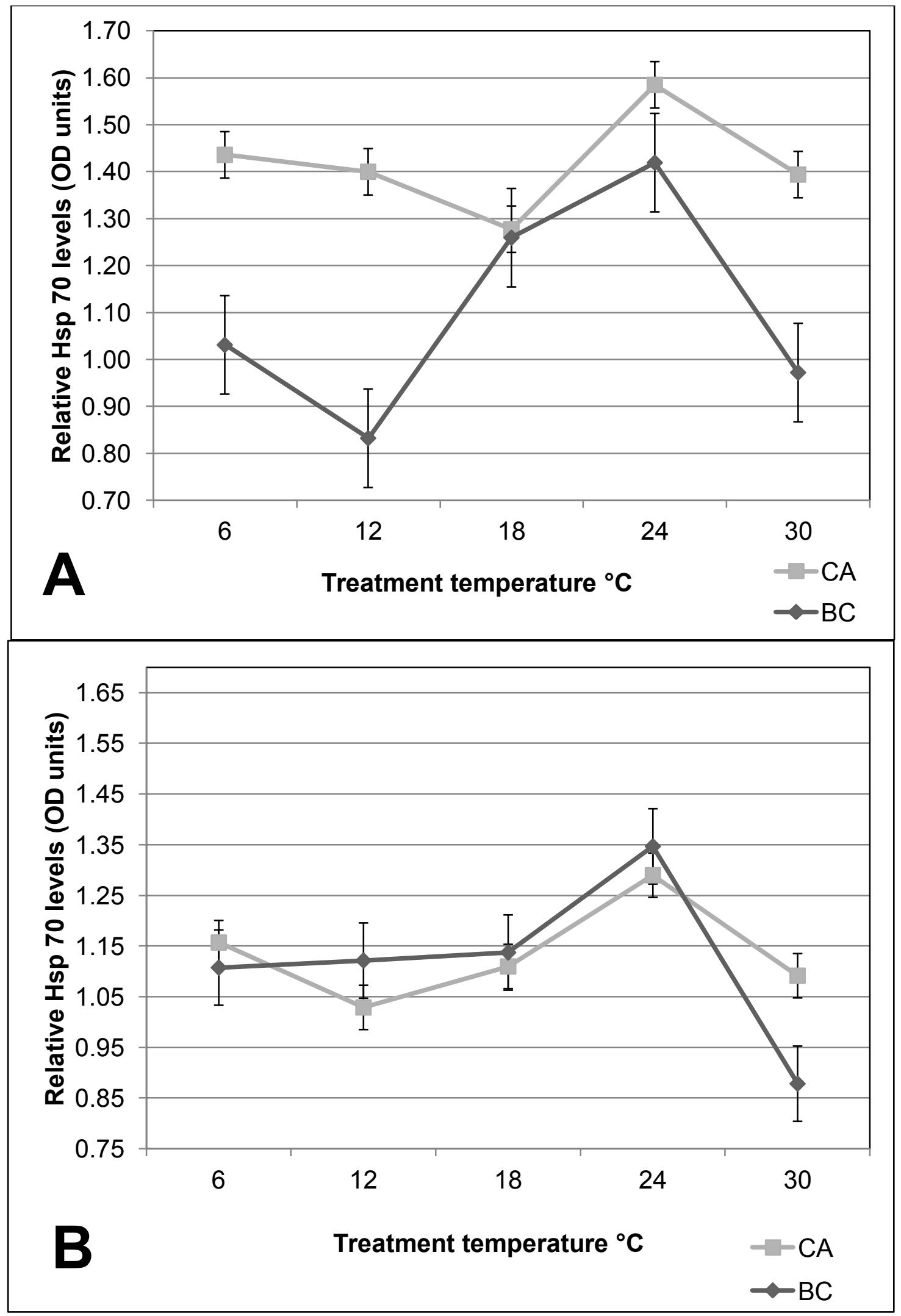


FIGURE 2.4 RELATIVE LEVELS OF HSP70 AT (A) 2 HR AND (B) 4 HRS AT TREATMENT TEMPERATURES OF $6,12,18,24$, AND $30^{\circ} \mathrm{C}$. LIGHT GREY= CA; DARK GREY= BC. ERROR BARS REPRESENT STANDARD ERROR. RELATIVE LEVELS OF HSP70 AT TIME 0 SHOWN AS $\square=1.27$ OD UNITS FOR CA CRABS AND $\bullet=1.27$ OD UNITS FOR CA CRABS AND $\bullet=0.99$ OD UNITS FOR BC CRABS.

\section{Morphometric analysis}

Morphometric analysis of CW for 2008 and 2009 using Mann-Whitney test revealed significant differences between $\mathrm{CA}$ and $\mathrm{BC}$ for both males and females. The CW of males sampled in 2008 from CA $(54.9 \pm 3.7 \mathrm{~mm}$, mean \pm SD, $n=56)$ was significantly lower $(p=0.0002)$ than that of the $B C$ males $(60.1 \pm 8.6 \mathrm{~mm}$, $n=26)$. Females displayed a similar difference in CW $(p=0.02)$. The mean CW was $50.6 \pm 3.8 \mathrm{~mm}$ for the CA females $(n=10)$ but $54.9 \pm 3.7 \mathrm{~mm}$ for the $B C$ females $(n=41)$. Measurements made in 2009 again yielded significant differences in CW $(p=0.0001$ for males and $p<0.0001$ for females). In males $(n=11)$, mean CW was $70.8 \pm 6.8 \mathrm{~mm}$ for the CA population and was $92 \mathrm{~mm} \pm 6.7 \mathrm{~mm}(\mathrm{n}=10)$ for those from BC. In females, mean CW was $61.6 \pm 4.5 \mathrm{~mm}(n=40)$ for crabs from CA and $73.2 \pm$ 5.6mm ( $n=27)$ for those from BC (Fig. 2.5 A,B). 


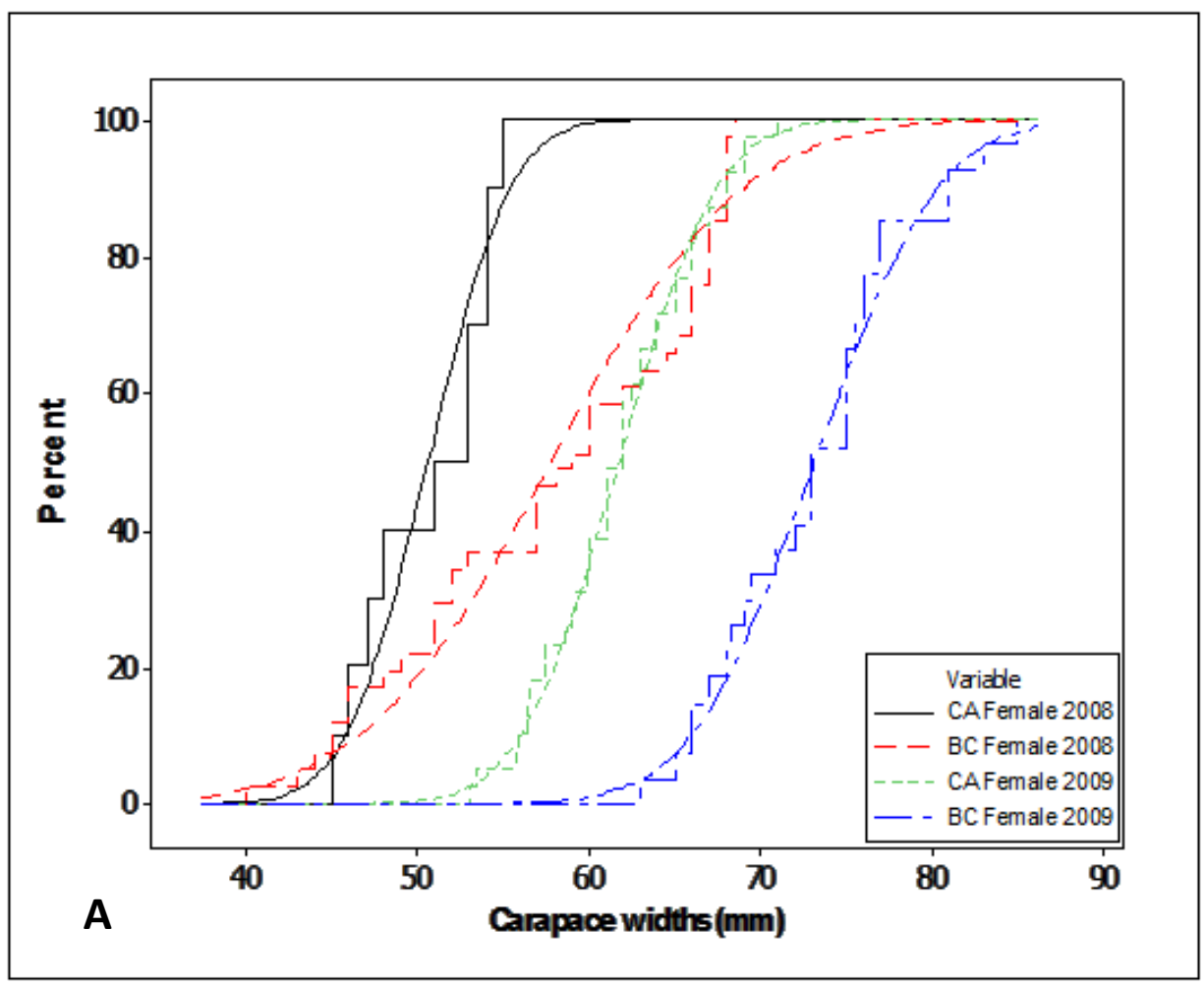




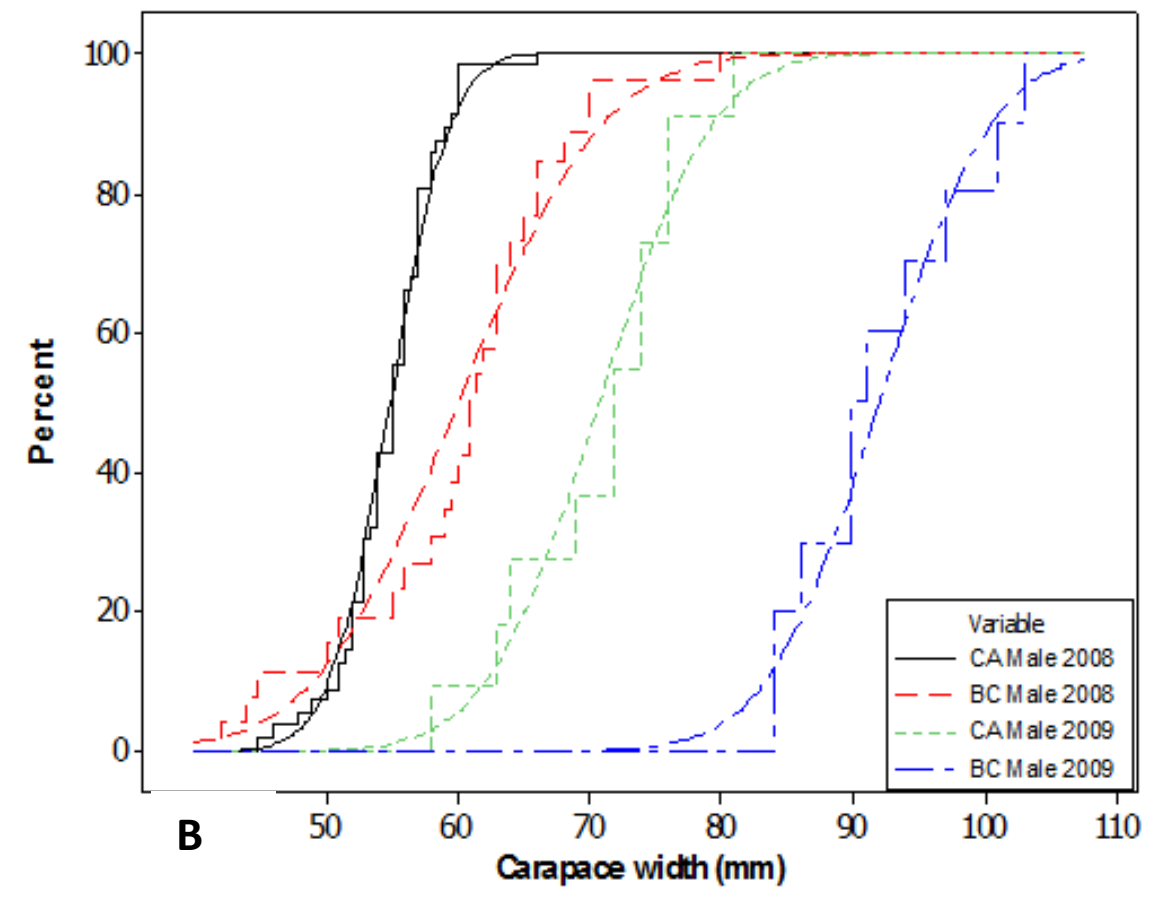

FIGURE 2.5 AN EMPIRICAL CUMULATIVE DISTRIBUTION FREQUENCY OF CARAPACE WIDTHS OF CARCINUS MAENAS FROM THE CALIFORNIA AND BRITISH COLUMBIA POPULATIONS FOR (A) FEMALES AND (B) MALES SAMPLED IN 2008 AND 2009.

\section{Discussion}

For marine ectotherms, temperature is an important governing force that influences biogeographical distributions within and across thermally heterogeneous environments (Somero 2002). Understanding the role that temperature plays in organismal function can lead to insights into the nature of adaptive variations in thermotolerance and temperature-sensitive physiological thresholds.

Our results suggest that divergence in the thermal physiology of two genetically similar populations of Carcinus maenas has occurred despite the short ( 20 yr) timeline of invasion. First, the California population (CA) had higher 
thermal tolerance than the northern, British Columbia population (BC) after cold $\left(6^{\circ} \mathrm{C}\right)$ and hot $\left(23^{\circ} \mathrm{C}\right)$ acclimation, as determined by the CTmax experiment (Fig.

2.2). Second, the CA cold-acclimated group was able to mount a strong Hsp70 response, stronger than the cold-acclimated $\mathrm{BC}$ one, in response to heat ramping (Fig. 2.3). Third, in the isolated tissue experiment, the CA group had greater standing stock levels of Hsp70 at time 0 , and had greater expression across all treatment temperatures at the $2 \mathrm{hr}$ time point (2.4 A). Taken together, these results suggest adaptive variation in thermotolerance. Such differences in thermal tolerances may be one reason why these populations thrive in both these latitudes despite their dissimilar thermal regimes and also may play a role in further range expansion. Analysis by Compton et al. (Compton et al. 2010b) suggests the ranges of $C$. maenas, in the east Pacific and elsewhere, are primarily constrained by temperature tolerances and our results are consistent with this conclusion.

\section{Thermotolerance}

Within each population, laboratory adjustment to the warmer acclimation temperature increased the mean CTmax but the CA group did not respond as strongly as the $\mathrm{BC}$ one. The $\mathrm{BC}$ group responded to thermal acclimation with a marked increase in mean CTmax of $3.83^{\circ} \mathrm{C}$ (Fig. 2.2). The comparatively modest increase of $1.47^{\circ} \mathrm{C}$ for the CA population suggests that its capacity to raise its upper thermal limit through acclimation is more constrained than that of its northern counterpart. The current distribution of the green crab on the west coast 
of North America may provide anecdotal evidence supporting this supposition, as its southern range boundary is Elkhorn Slough, CA, only $200 \mathrm{~km}$ south of the original site of introduction in San Francisco Bay, CA, and a small population formerly in Morro Bay, to the south of Elkhorn Slough, has not persisted. It has been shown that warm-adapted ectotherms whose upper thermal limit cannot be pushed via acclimation are living at or near the edge of their physiological tolerance limits, and are tethered to the climate envelope in which they currently exist (Stillman and Somero 1996, Stillman and Somero 2000). Range expansion, conversely, has proceeded rapidly and much further northward into seasonally cooler waters (Behrens-Yamada and Hunt 2000).

The finding that the upper thermal tolerance thresholds of two populations of this marine ectotherm reflect the thermal environment that they inhabit mirrors the results of previous inter- and intraspecific comparisons in a variety of taxa (see (Feder and Hofmann 1999). For instance, in a study on the common killifish Fundulus heteroclitus, critical thermal maxima were consistently higher in southern than in northern populations by $\sim 1.5^{\circ} \mathrm{C}$ across acclimation temperatures ranging from $2-34^{\circ} \mathrm{C}$ (Fangue et al. 2006). Similarly, an assessment of the thermotolerance of 20 congeners of porcelain crabs (genus Petrolisthes) from different vertical positions and different biogeographical regions in the eastern Pacific demonstrated that upper thermal tolerance thresholds were strongly correlated $\left(r^{2}=0.88\right)$ with maximal microhabitat temperatures experienced by each species, indicating that these species have modified upper tolerance limits 
that reflect their microhabitat conditions (Stillman and Somero 2000). Similar observations that such differences exist between subpopulations that have separated themselves geographically, but not genetically, over only two decades are scarce if not absent from the literature.

Relationship between upper thermal tolerance limits and Hsp70 expression

The heat shock response (HSR), defined as the stress-induced upregulation of heat shock proteins (Hsps), is the primary mechanism by which the cell can prevent or mediate the damage caused by macromolecular denaturation and cytotoxic protein aggregation (Lindquist 1986, Sanders 1993, Feder and Hofmann 1999). Since Hsp expression has been shown to be related to organismal thermotolerance, these proteins are an ecologically relevant metric for investigating inter- and intra-specific differences in thermal physiology. Plasticity in the thermal threshold for the expression of Hsps has been widely observed in the marine environment, with the onset temperature of expression generally being higher during warm seasons and in warmer environments (Hofmann and Somero 1995, Hofmann and Somero 1996a, Roberts et al. 1997, Tomanek and Somero 1999, Buckley et al. 2001, Buckley and Hofmann 2002).

In the present study, cellular response to thermal perturbation, as indicated by the quantification of Hsp70 levels, was supportive of the results observed at the organismal level. In accordance with the finding that the warmacclimated CA group had the highest organismal thermotolerance (ie. mean CTmax), this group also had the greatest degree of Hsp70 production (Fig.2.3). 
Additionally, there was a significant difference in the amount of Hsp70 produced in the $6^{\circ} \mathrm{C}$ acclimation groups which reflects the significant difference found between the organismal CTmax values after $6^{\circ} \mathrm{C}$ acclimation (Fig. 2.2).

Acclimation to $6^{\circ} \mathrm{C}$ appears to have decreased the ability of C. maenas sampled from $B C$ to mount a vigorous heat shock response. However, after acclimation at $23^{\circ} \mathrm{C}$ this group was able to produce $\mathrm{Hsp} 70$ at a level that was equivalent to its southern counterpart. The BC population may have downregulated Hsp production, as it is metabolically costly to mount such a response (Krebs and Holbrook 2001). Crabs from this population, when acclimated to $6^{\circ} \mathrm{C}$, failed to mount a strong Hsp response, unlike crabs acclimated in the laboratory to the warmer temperature or either of the lab-acclimated California treatments. They were therefore unable to respond to the large, experimental temperature increase and died at lower temperatures and sooner than all the other treatments. This suggests that the BC population may have differentiated from the CA one, perhaps because the response is not typically needed in the more northern waters.

Intraspecific differences in Hsp70 expression have previously been characterized in the marine whelk Nucella canaliculata, where warm-adapted individuals sampled from the southern edge of their range near Piedras Blancas, California had a more robust heat shock response than individuals sampled from the northern edge of their distribution (Sorte and Hofmann 2004). These results highlight the effect that disparate thermal histories can have on Hsp synthesis 
within a species across its range. Similarly, an analysis of Hsp70 mRNA expression of Strogylocentrotus purpuratus found that the southern population sampled from Carpenteria, CA had a significantly greater induction of Hsp70 mRNA than those specimens sampled from Fogarty Creek, Oregon after heat shock treatment (Osovitz and Hofmann 2005), again indicating site-specific thermal adaptation.

Intraspecific comparison of Hsp70 synthesis across a suite of treatment temperatures

In a separate experiment on isolated chelae muscle tissue, the California group produced significantly more Hsp70 than the BC one (Fig. 2.4 A,B). The CA group had greater Hsp70 levels at the control temperature of $6^{\circ} \mathrm{C}$ indicating that the CA group had a greater standing stock of Hsp70 at the start of the experiment than the BC group. Across temperatures, the Hsp70 expression patterns were generally similar; however, levels of Hsp70 were always greater in the CA group implying that this population has the capacity to mount a more vigorous heat shock response. Interestingly, both populations had reduced Hsp70 production at the $30^{\circ} \mathrm{C}$ treatment temperature, suggesting that this temperature was too extreme for this species to employ Hsp70 production as a stress response mechanism. These data parallel the trend seen in the Hsp70 analysis from the CTmax experiment where the CA group had a greater Hsp70 induction than the BC group at both acclimation treatment temperatures. 
These results indicate that $C$. maenas from colder habitats given cold acclimation possess an overall lower thermal set point for Hsp70 induction as exemplified by the low expression levels observed in the CTmax and isolated tissue experiments; suggesting they are more thermally sensitive than their warm-acclimated counterparts. Variations in the threshold of thermal set points across a geographic range are likely to be beneficial because over- or underexpression of Hsps can directly affect the fitness of an organism (Feder and Hofmann, 1999).

Taken together, our findings provide evidence that the north eastern Pacific population of C. maenas has incurred a shift in thermal tolerance compared to its southern counterpart. The mechanism driving the differences observed remains unclear, but thermal adaptation at the level of the phenotype is a likely cause due to the short timescale of the invasion and the genetic connectivity of the two populations.

\section{Variations in morphology}

Carapace widths $(\mathrm{CW})$ for both male and female C. maenas from $\mathrm{BC}$ were significantly greater than those found in CA (Fig. 2.6). 


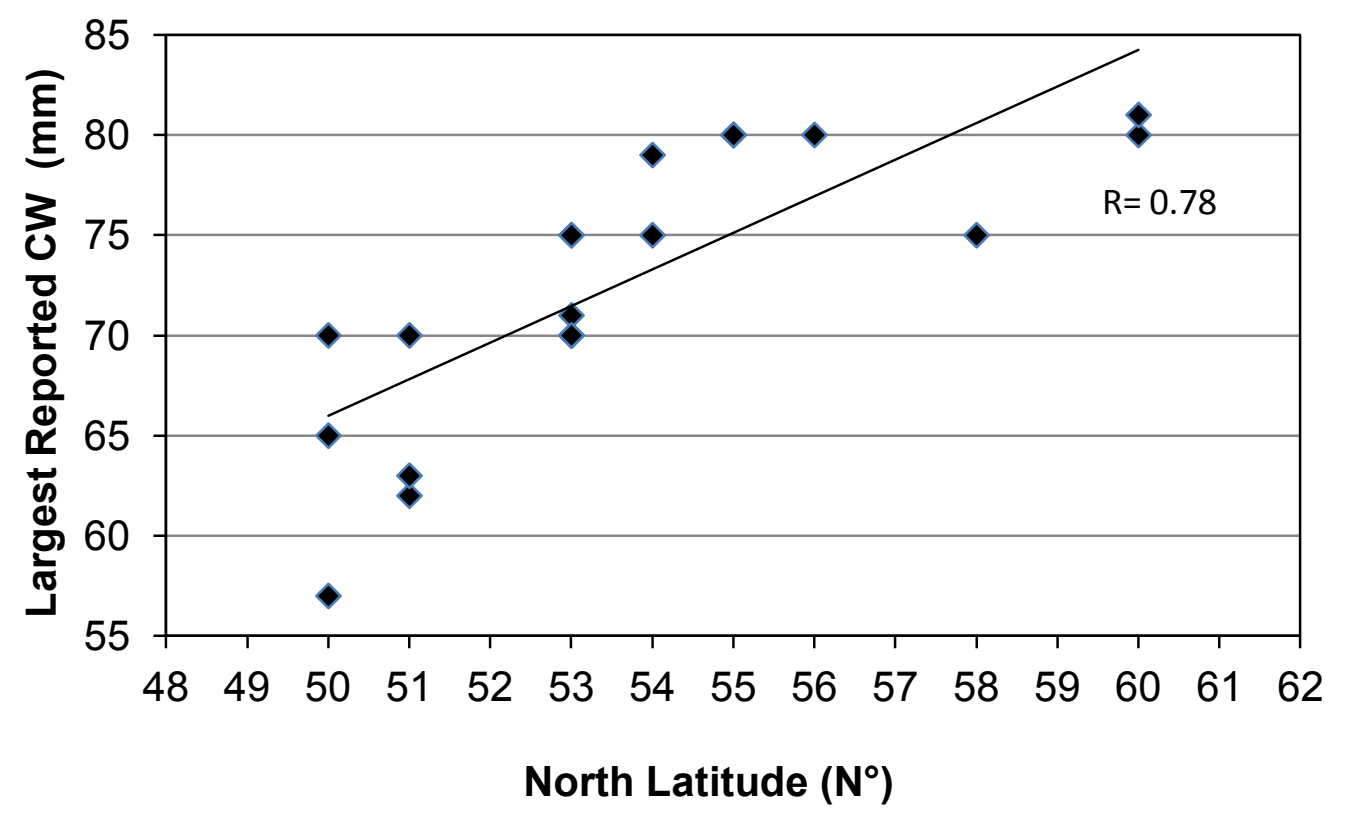

FIGURE 2.6 MAXIMUM REPORTED MALE CARAPACE WIDTH (MM) VERSUS THE LATITUDE OF EACH SAMPLE SITE (R=0.78) FROM C. MAENAS NATIVE RANGE.

Previously published data on $\mathrm{CW}$ for both populations were found to be congruent with our findings (Jensen et al. 2007, Behrens Yamada and Gillespie 2008). Jensen (2007) found mean CW for Bodega Bay, CA males and females for 1998 were $72 \mathrm{~mm}$ and $51 \mathrm{~mm}$, and for 2001 , the means for males and females were $71 \mathrm{~mm}$ and $54 \mathrm{~mm}$. An analysis of the CW for BC presented by Behrens Yamada, et al. (2008) found a bimodal distribution of CW for males in 2006, with nodes peaking at $63 \mathrm{~mm}$ and $85 \mathrm{~mm}$, signifying two year classes present at the time of sampling (Behrens Yamada and Gillespie 2008). Female CW distribution was broadly unimodal, with the node occurring between $50-60 \mathrm{~mm}$ (Behrens Yamada and Gillespie 2008). This type of body size patterning across a 
latitudinal cline has been noted in two other brachyuran decapods native to the eastern Pacific, Pachygrapsus crassipes and Hemigrapsus oregonensis (Hines 1989), and temperature was proposed to be one possible mechanism behind the observed variation in size.

Temperature has been implicated in facilitating many polyphenisms in arthropods, in particular the coloring of Manduca sexta, which is dictated by temperature during ontogeny (Suzuki and Nijhout 2006). Also, alternate developmental pathways associated with diapause were found to be regulated by temperature in embryos of the annual killifish Austrofundulus limnaeus (Podrabsky et al. 2010). In Drosophila, larvae reared in the lab at low temperatures had a reduced growth rate, which extended the larval period, conferring an increase in overall mass of the mature larvae, leading to a larger mature adult (Atkinson 1996). Moreover, Drosophila repeatedly bred at low temperatures for several years over many generations produced significant increases in body size, compared to their counterparts bred at higher temperatures (Partridge et al. 1994).

Previous studies on the larval development rate of the current study species collected from Tomales Bay, CA, found that zoeal development duration decreased as rearing temperature increased (de Rivera et al. 2007), as seen in Drosophila. Additionally, a clear relationship emerged between rearing temperature and mortality rates, as larval mortality increased with decreasing rearing temperature. Planktonic C. maenas larvae can take from 20 to 80 days to 
become competent to settle (Nagaraj 1993, de Rivera et al. 2007) allowing for long distance dispersal, which can be up to $50 \mathrm{~km} /$ day during an El Niño event (Barth and Smith 1998, Behrens-Yamada and Hunt 2000). In the case of the North American west coast population, larval exposure to cold temperatures at the forefront of the northward expansion could trigger an alternate developmental pathway prompting an overall slowing of metabolic processes and/or an alteration in the timing of genetic expression of key growth regulatory hormones, triggering larger body size (Nijhout et al. 2006).

Given that a single mitochondrial haplotype was detected in western North America (Darling et al. 2008, Tepolt et al. 2009), this population represents the lowest degree of genetic diversity of all global invasive and native populations of European green crabs (Darling et al. 2008). This information is supportive of the polyphenism hypothesis, where broad variation in a phenotype can be generated by a single genotype.

A linear regression analyzing reported male maximum $\mathrm{CW}$ and the latitude of each sample site (Table 2.1) found that latitude explained $61 \%$ of the variation in carapace width (Fig. 2.6). This analytical protocol was previously used to assess clinal variation in body size in four species of the triplefin blenny (Tritergiidae) in the Gulf of California where adult body size was better estimated by measuring the length of the largest individuals rather than the average weight per individual (Gilligan 1991). There was a measurable difference in morphology (CW) between these two populations, and we have presented a hypothesis as to 
why this has occurred; yet, we acknowledge that there are many environmental factors (eg. predation, prey availability, competition) that influence the final adult size of an organism. In addition, the BC population may represent older year classes on average than the California one due to more sporadic recruitment. It is beyond the scope of this paper to elaborate on alternative hypotheses as we lacked data needed for proper analysis. However, we are proposing that animals reared at low temperatures can induce a variation in phenotype, and may be one of several key environmental factors responsible for the difference in $\mathrm{CW}$ in $\mathrm{C}$. maenas.

It is well established that $C$. maenas is parasitized by several metazoan invertebrates in its native range in Europe, and a decrease in size and body mass has been associated with the prevalence of parasitic castrators (Torchin et al. 2001). However, in the same study, there was no significant difference in mean size between infected and uninfected individuals (Torchin et al. 2001). While it is possible that the decreased parasitism in the western North American population of $C$. maenas may be one factor facilitating greater growth, this appears not to be a significant determinant of size in its native range.

\section{Conclusions}

Invasive species arrive in new environments with genomes shaped by natural selection and other evolutionary processes that occurred in a different geographic region. Within the context of a novel environment, marine invasive organisms have several time scales upon which they can mitigate new 
environmental stressors. Within the lifetime of a given individual, genotypic adaptations to novel abiotic conditions are unavailable and so phenotypic and physiological plasticity is a primary means by which an invader can ameliorate the deleterious effects of environmental stressors. The eurythermality exhibited by $C$. maenas no doubt was an integral component of its initial success in establishing a viable population in the eastern Pacific and consequently its northward expansion up the west coast of North America. Our results indicate that a divergence in the phenotypic physiological response to temperature has occurred between the two populations of C. maenas on the west coast of North America over the course of the last two decades and that the northern population displays a significantly larger morphology. Identifying the mechanisms that underpin phenotypic divergence can aid in our understanding of why certain invasive species have the potential to be so successful at colonizing new locations. 


\section{CHAPTER THREE: COLD TOLERANCE OF THE INVASIVE CARCINUS MAENAS IN THE EAST PACIFIC: MOLECULAR MECHANISMS AND IMPLICATIONS FOR RANGE EXPANSION IN A CHANGING CLIMATE}

\section{Introduction}

Distributions of marine ectotherms are regulated by a combination of physiological capacity, biotic factors, and dispersal potential. Poleward range expansion is thought to be constrained by an organism's ability to withstand colder temperatures (Addo-Bediako et al. 2000). Examination of the potential for poleward range expansion, whether by the spread of non-native species or in response to changing environmental conditions such as global climate change therefore require investigation into cold tolerance and what physiological mechanisms may allow exploitation of colder environments (Crozier 2003, 2004). Projections of potential range expansion are often made via machine learning or statistical models that factor in a range of abiotic parameters (Peterson 2003, de Rivera et al. 2011). These models are useful in their ability to identify areas that fit species-level criteria for population growth, but ignore genetic and phenotypic differences across populations in their abilities to tolerate specific conditions. Physiological studies can provide mechanistic understanding of the role abiotic factors have in the distribution of species and can highlight differences between populations (Somero 2002, Stillman 2002). However, cellular physiology, while well-established for understanding the ranges of native organisms, has not often 
been used for the assessment of invasive organisms invading novel environments (Henkel and Hofmann 2009, Kelley et al. 2011, Urian 2011).

We therefore set out to determine whether we could use organismal and cellular physiology of an invading marine ectotherm to inform its potential for range expansion based on cold tolerance. We selected the crab Carcinus maenas for this exploration because its potential range in recipient regions has been modeled in multiple ways based on its other occupied habitat and its temperature-dependent larval development, which can serve as a comparison to our approach. In addition, we recently examined its upper thermal tolerance (Kelley et al. 2011). C. maenas has established viable populations in temperate coastal ecosystems globally (Carlton and Cohen 2003b). The ability of this eurythermal and euryhaline species to tolerate a wide range of abiotic conditions has no doubt been an integral component of its invasion success. The invasion of the northeast Pacific by C. maenas originated in San Francisco Bay, CA, in 1989 and has primarily spread northward into seasonally cooler waters (Behrens Yamada and Hunt 2000, See and Feist 2010), suggesting warm water temperatures may be limiting southward spread but cold stress is not yet limiting northward spread. Given that temperature has been suggested as the main limiting factor for northward spread elsewhere in this species (Audet et al. 2008), determining the temperatures at which cold may become a limiting factor for $C$. maenas in the northeastern Pacific given further range expansion can bring to 
light projections of poleward range limits and surveys for monitoring northward invasion.

The upper thermal tolerance thresholds of adult specimens of $C$. maenas vary between populations near the present boundaries of its northeast Pacific range. Crabs sampled from a northern site, Vancouver Island, British Columbia (BC), Canada had a significantly lower upper thermal tolerance (critical thermal maxima[CTM]) and lower levels of expression of the inducible heat shock protein 70 (Hsp70) after laboratory acclimation at $6^{\circ} \mathrm{C}$ when compared to a population from a southern site, Seadrift Lagoon, California, USA (CA) (Kelley et al. 2011). These results highlight the ability of the geographically disparate populations of this crab to modulate their upper organismal and cellular thermotolerance differentially to reflect the thermal environment each now inhabits, despite the highly similar genetic history of the populations (Darling et al. 2008, Tepolt et al. 2009). Such modulation of thermotolerance by these recently separated ( 20 years) populations mirrors differences in thermotolerance found in native ectotherms that have had millennia to make adaptive changes to their genomes (Somero 2002, 2005). Hence, site-specific variation in Hsp70 modulation across this recipient range is one cellular mechanism that this species utilizes that likely increases invasion capacity. These sample-site variations in Hsp70 expression led our investigation to explore how cold stress may facilitate differential cellular responses in crabs collected from different populations across their invaded range. 
Our aim was to determine experimentally whether $C$. maenas in the northeastern Pacific could tolerate conditions farther north and to determine what, if any, cellular physiological mechanisms may be differentially utilized to facilitate additional northward range expansion given propagule spread. We used two approaches. First, we examined whether adult crabs from a potential donor population from BC could tolerate thermal conditions beyond the present northern boundary. Additionally, we used the laboratory-derived cold-tolerance data to gain a greater understanding of how the geographic boundary of this species may be altered in response to ocean warming that is a result of global climate change (Sunday et al. 2012). Second, to determine whether different populations vary in their expression of key proteins involved in the cellular stress response, and therefore may possess different capacities to invade cold areas, we compared two populations in their cellular response to cold temperatures typical of more poleward regions. Such research can provide general insight into the invasion processes.

There is not yet a standardized method to test for environmental stress on a cellular level. Heat shock proteins have often been used, but other approaches have also found success (Frederich et al. 2009, Jost et al. 2012). The cellular stress response [CSR] model identifies four major stress-induced signal transduction pathways, the function of which is evolutionarily conserved across taxa; they include 1) DNA repair and apoptotic pathways, 2) ubiquitin/proteosome pathways, 3) protein chaperone modulation/production and 4) cell cycle 
checkpoint control leading to growth arrest, (Kültz 2003, 2005). We used the CSR model to examine how acute cold stress/cold shock affects cellular homeostasis in different populations of this species. We evaluated two proteins, each involved in one of the latter two stress-signaling pathways, the inducible protein chaperone Hsp70 and cell cycle modulator, cyclin D1.

Protein chaperoning by the inducible isoform of heat shock proteins (Hsps) plays a fundamental role in the refolding of denatured proteins that are a product of exposure to a range of environmental stressors from thermal stress to UV damage (Feder and Hofmann 1999). Furthermore, it is worth noting that many polar ectotherms produce Hsps constitutively, perhaps to maintain proper protein folding in the cold (Hofmann et al. 2000, Rinehart et al. 2006). Coldinduction of Hsps in eurythermal ectotherms may therefore be necessary for routine protein homeostasis at lower temperatures. Hsp70 has been found to be up-regulated during bouts of cold stress in the invasive mussel, Perna viridis (Urian 2011) and many other poikilotherms (Cox et al. 1993, Holland et al. 1993, Laios et al. 1997, Fujita 1999, Ali et al. 2003), providing us with the testable hypothesis that Hsp70 would be upregulated during cold shock.

Emerging evidence illustrates that cell cycle down-regulation/arrest is another avenue the cell utilizes to initiate a stress response (Sampetrean et al. 2009, Bin and Wei-Hua 2011, Buckley 2011). Cyclin D1 is an important regulator of cell cycle progression, and accumulating evidence shows that the repression of cyclin D1 arrests cell proliferation, thereby minimizing growth in suboptimal 
conditions (Baldin 1993; Casanovas 2000; Mukhopadhyay et al. 2002). The vast biomedical literature on cyclin D1 has clearly established its role as a critical cell cycle modulator (Sherr 1994, Morgan 1997, Fu et al. 2004). This work has demonstrated that for a variety of organisms, from yeast to humans, environmental stressors such as heat shock and osmotic stress inhibit cyclin D1 expression, resulting in cell cycle arrest (Rowley et al. 1993, Casanovas et al. 2000, Han et al. 2002, Guo et al. 2009), and may allow the metabolic energy used for cell replication to be shunted to stress-induced cellular pathways (Kültz $2003,2005)$. The ability of the cell to modulate cell cycle progression in response to environmental conditions thus provides ecological relevance for the use of cyclin D1 as a possible bio-indicator of environmental stress. While we did not measure cell proliferation directly, cyclin D1 expression has been shown to be an important factor in orchestrating cell cycle progression and proliferation (Mukhopadhyay et al. 2002).

We hypothesized that crabs would exhibit plasticity across populations and recent thermal history in the onset temperatures for the expression of cyclin D1 and Hsp70 in C. maenas. By quantifying these two proteins in individuals maintained at two laboratory acclimation temperatures, we hoped to characterize the effect of differential acclimation on the cyclin D1 synthesis of organisms sampled from disparate thermal habitats, perhaps identifying the thermal environment that is results in a greater expression of cyclin D1 in this species. 
The goals of the study were 1) to test whether adult $C$. maenas sampled from Vancouver Island, British Columbia, were capable of tolerating temperatures that mirror those of winter conditions outside of their current range and 2) using the CSR conceptual framework, to measure the expression of the cell-cycle regulator cyclin D1 and the protein chaperone Hsp70 in response to cold exposure. This tested for variation in expression of these proteins, based on where they were collected or the temperature to which they were acclimated in the laboratory, together reflecting the cellular stress response. In doing so, we hope to gain greater insight into the cellular processes that may facilitate range expansion in this species.

\section{Materials and Methods}

\section{Animal collection and maintenance}

Intermolt (characterized by a hard cuticle) adult male and female Carcinus maenas were collected via Fukui fish traps from subtidal locations at Seadrift Lagoon, California, USA $\left(37^{\circ} 54^{\prime} 27.82^{\prime \prime} \mathrm{N}, 122^{\circ} 40^{\prime} 19.56 " \mathrm{~W}\right)$, Pipestem Inlet, Vancouver Island, British Columbia, Canada $\left(49^{\circ} 02.3^{\prime} \mathrm{N}, 125^{\circ} 12.2^{\prime} \mathrm{W}\right)$, and Kyuquot Sound, Vancouver Island, British Columbia, Canada $\left(50^{\circ} 02^{\prime} \mathrm{N}\right.$, $\left.127^{\circ} 22^{\prime} \mathrm{W}\right)$ (Fig. 3.1). 


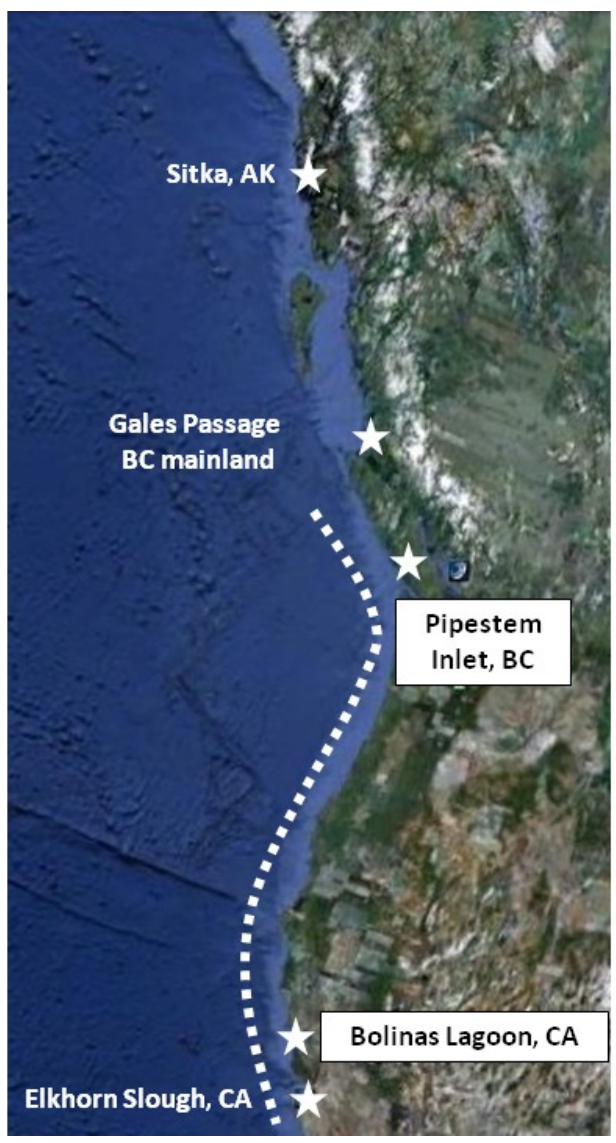

FIGURE 3.1 THE CURRENT DISTRIBUTION OF CARCINUS MAENAS ON THE WEST COAST OF NORTH AMERICA, FROM ELKHORN SLOUGH, CALIFORNIA, TO GALES PASSAGE, BRITISH COLUMBIA MAINLAND. MARKED ALSO ARE THE SAMPLE SITES FOR THIS STUDY: PIPESTEM INLET BRITISH COLUMBIA, CANADA AND SE SEA SEADRIFT LAGOON, CALIFORNIA, USA, AS WELL AS THE SITE WITH THE OVERWINTER THERMAL PROFILE, SITKA, ALASKA.

These sites are similar to each other in that they support large populations $(>10,000)$, are near the range edges for this species, and have steep intertidal zones that reduce the likelihood that the specimens would have experienced thermal alterations from changes in air temperature in the exposed intertidal. The cold shock experiment focused on crabs sampled from both locations in 2008. In May 2010, crabs were sampled from Kyuquot Sound for the cold tolerance experiment. 
During the laboratory and experimental acclimation periods (6 or $\left.23^{\circ} \mathrm{C}\right)$, crabs were held in temperature-controlled, recirculating aquaria in artificial seawater (Instant Ocean) at 34 ppt salinity. Once each week, water was changed and the crabs were fed mussels (Mytilus edulis, aquaculture product) ad libitum. Temperatures were maintained within $\pm 1^{\circ} \mathrm{C}$ of the target temperatures during acclimation.

\section{Whole organism cold tolerance capacity}

To test whether the cold tolerance capacity of adult C. maenas would allow adult survival north of the current range, animals were held at a winter thermal profile generated from Sitka, Alaska (AK) (Fig. 3.2). After animals $(n=15)$ were laboratory acclimated to $10^{\circ} \mathrm{C} \pm 1{ }^{\circ} \mathrm{C}$ for four weeks, crabs were held to the Sitka winter thermal profile. This profile was generated using NOAA buoy data (Lat: $57^{\circ} 3.1^{\prime} \mathrm{N}$, Long: $135^{\circ} 20.5^{\prime} \mathrm{W}$, NOS buoy \# 9451600) gathered from 11 October 2008 through 25 June 2009. Weekly means from hourly temperature readings were generated after removing missing and anomalous readings (beyond the scope of what was to be expected for that time of year, e.g. 999) from the dataset. We chose $10^{\circ} \mathrm{C}$ as the start and end point for our experiment based on prior work showing low thermal stress (lack of Hsp 70 regulation) in the BC population at $6^{\circ}$ and $12^{\circ} \mathrm{C}$. Crabs were held to the profile temperature $\pm 0^{\circ} \mathrm{C}$ for the 38 wks of this experiment. Conservatively, we rounded down the buoy data to the lower integer temperature in the laboratory experiment (a NOAA reading of $5.9^{\circ}$ translated to $5.0^{\circ}$ in lab). Survival was the metric for this assay. 


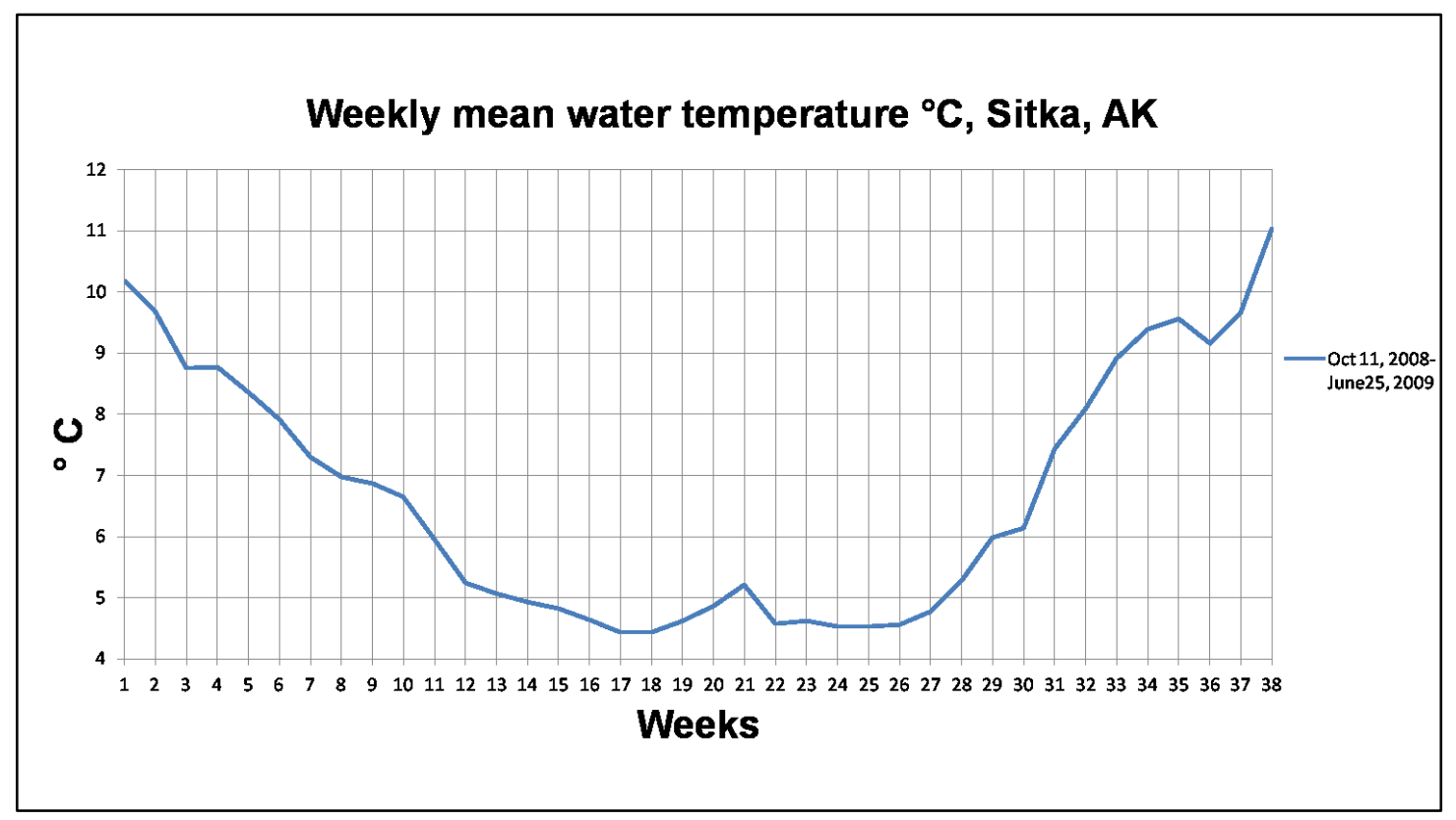

FIGURE 3.2 OVER-WINTER THERMAL PROFILE. GENERATED FROM NOAA BUOY DATA GATHERED FROM 2009 FOR SITKA, AK.

\section{Cold shock experiment}

Animals were laboratory acclimated for four weeks at $12^{\circ} \mathrm{C}$ after field collection. Crabs from each population were then split into two groups $(n=15$ each group, 60 total) and acclimated to either $6^{\circ} \mathrm{C}$ or $23^{\circ} \mathrm{C}$ for six weeks prior to use in experiments. These experimental acclimation temperatures were chosen because they are representative of low and high temperatures experienced by this metapopulation at its current northern and southern range limits. During summer, the southern population can regularly experience temperatures at or near $23^{\circ} \mathrm{C}$ while minimum winter water temperatures decline to $\sim 11^{\circ} \mathrm{C}$ (http://cdmo.baruch.sc.edu). In contrast, waters near the northern population drop down to $6^{\circ} \mathrm{C}$ during the winter but warm to $\sim 14^{\circ} \mathrm{C}$ during the summer (http://www-sci.pac.dfo-mpo.gc.ca/osap/data). 
Five crabs per treatment were collected from each acclimation tank and immediately sacrificed as controls for comparison with the experimentally cooled crabs. Muscle tissue was taken from the chelae of each individual and flash frozen in liquid $\mathrm{N}_{2}$. The tissue was stored in a $-80^{\circ} \mathrm{C}$ freezer for later molecular analysis. Remaining crabs were moved to an insulated, aerated cooler and chilled by a recirculating water cooler (Lauda Econoline RE-106). Starting at the acclimation temperature of either 6 or $23^{\circ} \mathrm{C}$, water temperature was decreased at a rate of $2^{\circ} \mathrm{C}$ every 30 minutes, thus avoiding shock due to the rate of temperature change. It was not possible to measure critical thermal minima because exposure to near-freezing temperatures precipitates cold-induced torpor rather than immediate death. Instead, all animals were chilled to the point at which platelet ice appeared, -1.3 to $-1.5^{\circ} \mathrm{C}$, assuring all organisms were exposed to the same rate and depth of cold shock. Muscle tissue was sampled and frozen, as above.

\section{Quantification of Hsp70 and cyclin D1 concentration via western blotting}

All tissue samples were homogenized in lysis buffer $\left(32 \mathrm{mmol}^{-1}\right.$ Tris- $\mathrm{Cl}, \mathrm{pH}$ $6.8,0.2 \%$ sodium dodecyl sulfide [SDS]), and boiled for $5 \mathrm{~min}$ at $100^{\circ} \mathrm{C}$. Samples were then centrifuged at $12,000 \times \mathrm{g}$ at $20^{\circ} \mathrm{C}$. Supernatants were extracted for the following analyses. Protein concentrations were established via Bradford assay (Pierce Rockford, IL, USA). A $25 \mu \mathrm{g}$ sample of total protein was separated using SDS gel electrophoresis on $10 \%$ polyacrylamide gels and transferred to nitrocellulose membranes via overnight electrotransfer at $30 \mathrm{~V}$ on ice. Blots were 
then incubated in an anti- Hsp70 rabbit polyclonal IgG antibody (Santa Cruz Biotechnology, Santa Cruz, CA, USA), or anti-cyclin D1 rabbit polyclonal antibody (Thermo Scientific, Pittsburg, PA, USA) at a 1:1000 dilution in 5\% nonfat dried milk in 1x PBS, for $1.5 \mathrm{~h}$ on a shaker, at room temperature. The blots were then incubated in a horseradish peroxidase (HRP)-conjugated goat anti-rabbit secondary antibody (Thermo Scientific, Pittsburg, PA, USA) at a 1:10,000 dilution for $1 \mathrm{~h}$. Blots were visualized via enhanced chemiluminescence (SuperSignal reagent; Pierce, Rockford, IL, USA) followed by exposure to X-ray film (Kodak X-OMAT AR; Sigma). An internal standard was used to normalize measurements between blots. Densitometry measurements were performed using ImageJ freeware.

\section{Statistical Analysis}

Each group (site $x$ acclimation temperature $x$ treatment, 8 total) was examined using the Anderson-Darling normality test and Grubb's test for outliers, ensuring they met the assumptions for ANOVA ( $p>0.05$ for all datasets). Fully factorial ANOVAs analyzed the individual and interacting effects of sample site, acclimation temperature, and treatment on cyclin D1 expression or the Hsp70 response to cold stress. When the ANOVAs revealed significant effects, TukeyKramer post-hoc tests comparing expression levels within acclimation temperature groups, 6 or $23^{\circ} \mathrm{C}$, were utilized to make multiple comparisons between groups.

\section{Results}


Cold tolerance capacity

The BC crabs were successful in surviving the Sitka, AK overwinter thermal profile with a 93\% (14/15) survival rate. Only one animal died during week 17, over the course of the 38-week experiment, despite being kept for 18 weeks at or below $5^{\circ} \mathrm{C}$. These crabs continued to feed throughout this assay, though they did seem to reduce their movement speed at the colder temperatures.

Cold shock experiment: Cyclin D1 and Hsp70 protein analyses

Acclimation temperature had a significant effect on cyclin D1 expression, with greater expression at the $6^{\circ} \mathrm{C}$ acclimation temperature than the $23^{\circ} \mathrm{C}$ one $(p=0.024 ;$ Table 3.1).

Analysis of Variance- General Linear Model: Cyclin D1 relative OD units versus Site, acclimation temperature, treatment

\begin{tabular}{cccc}
\hline Factor & Type & Levels & Values \\
\hline Site & fixed & 2 & $\mathrm{BC}, \mathrm{CA}$ \\
Acclimation & fixed & 2 & $6,23^{\circ} \mathrm{C}$ \\
temperature & & & \\
Treatment & fixed & 2 & Control, Ramp down \\
\hline
\end{tabular}




\begin{tabular}{|c|c|c|c|c|c|c|}
\hline Source & DF & Seq SS & Adj SS & Adj MS & F & P \\
\hline Site & 1 & 0.0042 & 0.1487 & 0.1487 & 1.45 & 0.233 \\
\hline Acclimation temperature & 1 & 0.0246 & 0.5447 & 0.5447 & 5.31 & 0.024 \\
\hline Treatment & 1 & 0.0083 & 0.0014 & 0.0014 & 0.01 & 0.908 \\
\hline $\begin{array}{c}\text { Site*Acclimation } \\
\text { temperature }\end{array}$ & 1 & 0.7694 & 0.0806 & 0.0806 & 0.79 & 0.379 \\
\hline $\begin{array}{c}\text { Site*Treatment } \\
\text { Acclimation }\end{array}$ & 1 & 0.1068 & 0.1539 & 0.1539 & 1.5 & 0.225 \\
\hline $\begin{array}{c}\text { temperature*Treatment } \\
\text { Site*Acclimation } \\
\text { temperature*Treatment }\end{array}$ & 1 & 0.8232 & 0.8232 & 0.8232 & 8.03 & 0.006 \\
\hline
\end{tabular}

TABLE 3. 1 GLM ANALYSIS OF VARIANCE FOR CYCLIN D1 PROTEIN EXPRESSION.

We found a strong interaction between acclimation temperature and the ramp down treatment $(p<0.001)$, with crabs producing less cyclin D1 during ramp down than controls when they had been cold acclimated, but producing more when warm acclimated (Fig. 3.3). 


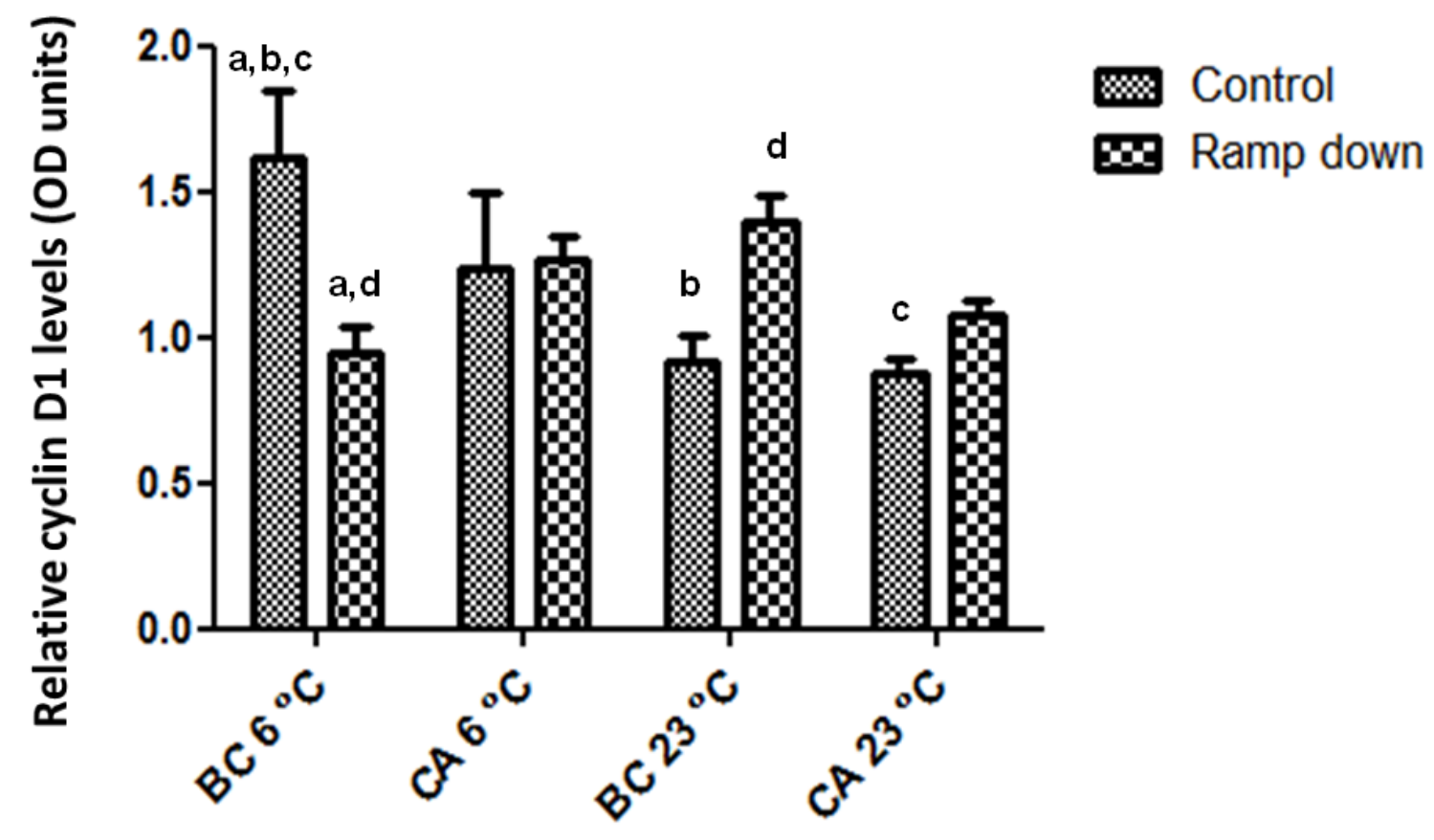

FIGURE 3. 3 CYLIN D1 PROTEIN LEVELS IN C. MAENAS. RELATIVE LEVELS OF CYCLIN D1 AT CONTROL SAMPLING AND AFTER COLD SHOCK FOR CRABS SAMPLED FROM THE CALIFORNIA-CA POPULATION AND THE VANCOUVER ISLAND-BC POPULATION AFTER LAB ACCLIMATION AT 6 AND $23^{\circ} \mathrm{C}$ RESPECTIVELY; BAR SHOW MEAN \pm 1 SE. MEANS WITH DIFFERENT LETTERS ARE SIGNIFICANTLY DIFFERENT, $(P<0.05)$.

Similarly, the interaction between site, acclimation temperature, and treatment was significant $(p=0.006)$. The other factors and interactions did not significantly affect cyclin D1 expression (Table 3.1). Post-hoc tests revealed significantly higher $(p<0.05)$ cyclin $\mathrm{D} 1$ expression in the $\mathrm{BC} 6^{\circ} \mathrm{C}$ control than the $\mathrm{BC} 6^{\circ} \mathrm{C}$ ramp down, $\mathrm{BC} 23^{\circ} \mathrm{C}$ control, and $\mathrm{CA} 23^{\circ} \mathrm{C}$ control (Fig. 3.3, Table 3.2). Additionally, the $\mathrm{BC} 23^{\circ} \mathrm{C}$ ramp down crabs produced significantly more cyclin $\mathrm{D} 1$ than the $\mathrm{BC}$ $6^{\circ} \mathrm{C}$ ramp down crabs did (Fig. 3.3). The $23^{\circ} \mathrm{C}$ post-hoc comparisons also revealed significantly higher cyclin $\mathrm{D} 1$ expression in the $\mathrm{BC} 23^{\circ} \mathrm{C}$ ramp down 
crabs than their control group $(p<0.01)$, the $C A 23^{\circ}$ ramp down crabs, and the $C A$ $23^{\circ} \mathrm{C}$ control group $(\mathrm{p}<0.01$; Table 3.2$)$.

\begin{tabular}{|c|c|c|c|}
\hline Comparison & Sample size & $\begin{array}{c}\text { Mean } \\
\text { difference }\end{array}$ & $P$ value \\
\hline $\begin{array}{c}\mathrm{BC} 6{ }^{\circ} \mathrm{C} \text { control vs. } \mathrm{BC} 6{ }^{\circ} \mathrm{C} \text { ramp } \\
\text { down }\end{array}$ & Whole data set & 0.6676 & $P<0.05$ \\
\hline $\mathrm{BC} 6^{\circ} \mathrm{C}$ control vs. $\mathrm{BC} 23^{\circ} \mathrm{C}$ control & & 0.6942 & $P<0.05$ \\
\hline $\mathrm{BC} 6^{\circ} \mathrm{C}$ control vs. $\mathrm{CA} 23^{\circ} \mathrm{C}$ control & & 0.7358 & $P<0.05$ \\
\hline $\begin{array}{c}\mathrm{BC} 6^{\circ} \mathrm{C} \text { ramp down vs. } \mathrm{BC} 23^{\circ} \mathrm{C} \\
\text { ramp down }\end{array}$ & & -0.4499 & $P<0.05$ \\
\hline $\begin{array}{c}\mathrm{BC} 23^{\circ} \mathrm{C} \text { control vs. } \mathrm{BC} 23^{\circ} \mathrm{C} \text { ramp } \\
\text { down }\end{array}$ & $\begin{array}{c}23^{\circ} \mathrm{C} \\
\text { Acclimation }\end{array}$ & -0.4765 & $P<0.01$ \\
\hline $\begin{array}{c}\mathrm{BC} 23^{\circ} \mathrm{C} \text { ramp down vs. } \mathrm{CA} 23^{\circ} \mathrm{C} \\
\text { control }\end{array}$ & & 0.5181 & $P<0.01$ \\
\hline $\begin{array}{c}\mathrm{BC} 23^{\circ} \mathrm{C} \text { ramp down vs. CA } 23^{\circ} \mathrm{C} \\
\text { ramp down }\end{array}$ & & 0.3186 & $P<0.05$ \\
\hline
\end{tabular}

TABLE 3. 2 POST-HOC COMPARISONS OF CYCLIN D1 PROTEIN EXPRESSION. (ONLY A FEW SIGNIFICANT INTERACTIONS ARE DENOTED IN FIGURE 3.3).

Acclimation temperature was the only factor that significantly affected Hsp70 expression $(p<0.001)$, with greater expression in the warm acclimated treatment than the cold (Fig. 3.4, Table 3.3). Post-hoc comparison found significantly lower Hsp70 expression in the $\mathrm{BC} 6^{\circ} \mathrm{C}$ ramp down than in either the BC $23^{\circ} \mathrm{C}$ ramp down $(p<0.01)$ or $\mathrm{CA} 23^{\circ} \mathrm{C}$ ramp down $(p<0.05)$ (Fig. 3.4, Table 3.4). 


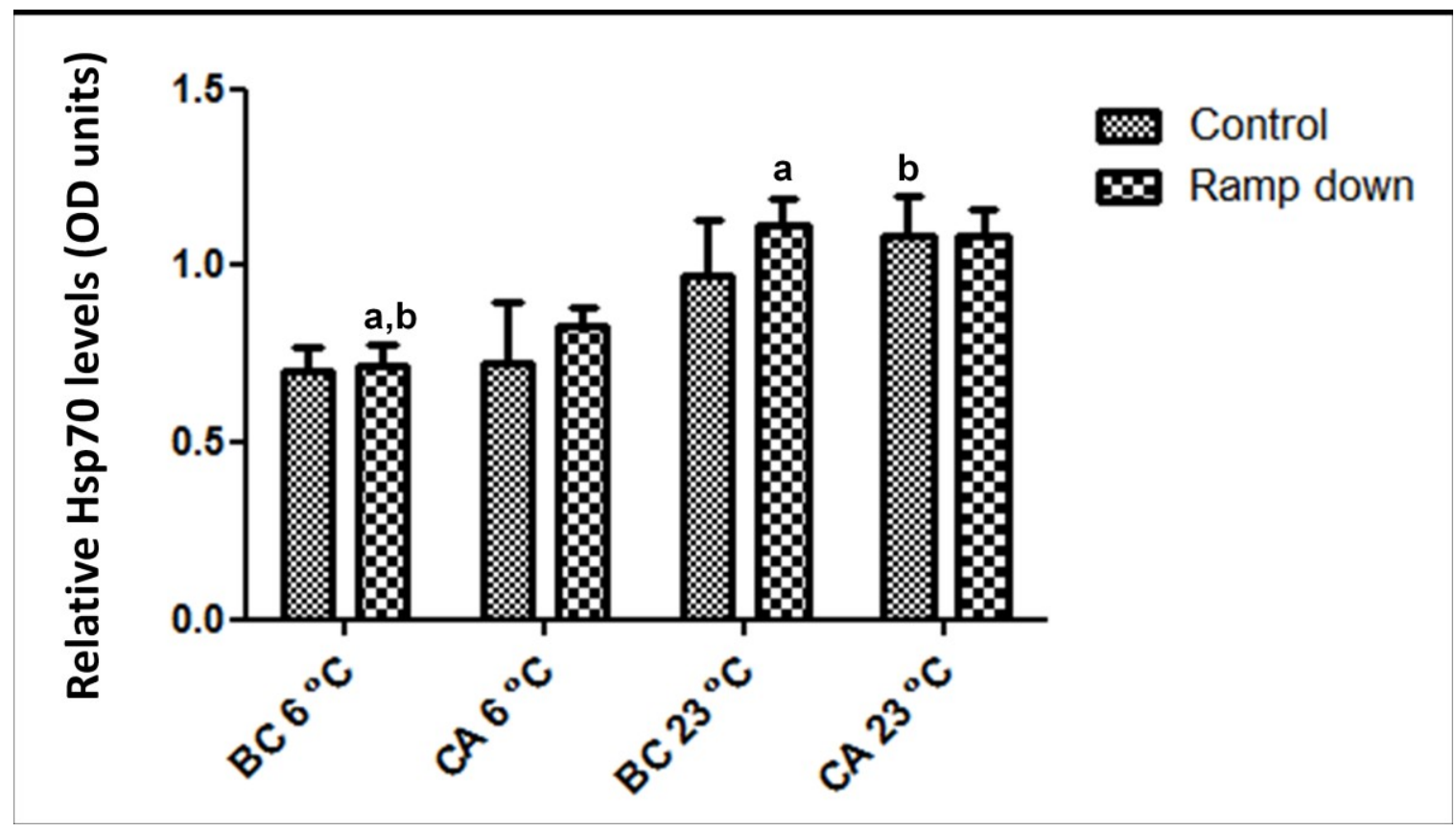

FIGURE 3.4 HSP70 LEVELS IN C. MAENAS. RELATIVE LEVELS OF HSP70 AT CONTROL SAMPLING AND AFTER COLD SHOCK FOR CRABS SAMPLED FROM THE CALIFORNIA-CA POPULATION AND THE VANCOUVER ISLAND-BC POPULATION AFTER LAB ACCLIMATION AT 6 AND $23^{\circ} \mathrm{C}$ RESPECTIVELY. BARS SHOW MEAN \pm 1 SE. MEANS WITH DIFFERENT LETTERS ARE SIGNIFICANTLY DIFFERENT, $(P<0.05)$.

Analysis of Variance- General Linear Model: Hsp70- relative OD units versus site, acclimation temperature, treatment

\begin{tabular}{cccc}
\hline Factor & Type & Levels & Values \\
\hline Site & fixed & 2 & $\mathrm{BC}, \mathrm{CA}$ \\
Acclimation & fixed & 2 & $6,23^{\circ} \mathrm{C}$ \\
temperature & & 2 & Control, Ramp down \\
Treatment & fixed & 2 &
\end{tabular}




\begin{tabular}{|c|c|c|c|c|c|c|}
\hline Source & DF & Seq SS & Adj SS & Adj MS & F & P \\
\hline Site & 1 & 0.03494 & 0.03865 & 0.03865 & 0.61 & 0.438 \\
\hline $\begin{array}{c}\text { Acclimation } \\
\text { temperature }\end{array}$ & 1 & 1.83487 & 1.41801 & 1.41801 & 22.33 & 0.000 \\
\hline Treatment & 1 & 0.05903 & 0.05546 & 0.05546 & 0.87 & 0.354 \\
\hline $\begin{array}{c}\text { Site*Acclimation } \\
\text { temperature }\end{array}$ & 1 & 0.02973 & 0.00293 & 0.00293 & 0.05 & 0.831 \\
\hline Site*Treatment $^{*}$ & 1 & 0.00232 & 0.00208 & 0.00208 & 0.03 & 0.857 \\
\hline $\begin{array}{c}\text { Acclimation } \\
\text { temperature*Tre } \\
\text { atment }\end{array}$ & 1 & 0.00029 & 0.00062 & 0.00062 & 0.01 & 0.922 \\
\hline $\begin{array}{c}\text { Site*Acclimation } \\
\text { temperature*Tre } \\
\text { atment }\end{array}$ & 1 & 0.04607 & .04607 & 0.04607 & 0.73 & 0.398 \\
\hline
\end{tabular}

TABLE 3. 3 GLM ANALYSIS OF VARIANCE OF HSP70 PROTEIN EXPRESSION.

\begin{tabular}{|cccc|}
\hline Comparison & $\begin{array}{c}\text { Sample } \\
\text { size }\end{array}$ & $\begin{array}{c}\text { Mean } \\
\text { difference }\end{array}$ & P value \\
\hline $\mathrm{BC} 6{ }^{\circ} \mathrm{C}$ ramp down vs. $\mathrm{BC} 23^{\circ} \mathrm{C}$ & $\begin{array}{c}\text { Whole } \\
\text { ramp down }\end{array}$ & -0.3993 & $\mathrm{P}<0.01$ \\
$\mathrm{BC} 6{ }^{\circ} \mathrm{C}$ ramp down vs. CA $23^{\circ} \mathrm{C}$ & & -0.3676 & $\mathrm{P}<0.05$ \\
ramp down & & data set & \\
\hline
\end{tabular}

TABLE 3.4 POST-HOC COMPARISONS OF HSP70 PROTEIN EXPRESSION.

\section{Discussion}

Ecological factors are responsible for determining range boundaries for all organisms (Brown et al. 1996); for marine ectotherms, abiotic parameters are of particular significance, as physiological tolerances are paramount in determining the width and breadth of geographic patterning (Pörtner 2002b, Somero 2002, 2005). Here, investigations into the cold tolerances and molecular responses to temperature in two populations of $C$. maenas demonstrated that 1) adults sampled from Vancouver Island, BC are capable of tolerating thermal conditions 
characteristic of Sitka, Alaska, an area beyond the current range limit of this expanding metapopulation; 2) cyclin D1 is thermally modulated in C. maenas; 3) the $\mathrm{BC}$ group is more physiologically responsive within the context of its cooler local habitat, as is evidenced by its ability to suppress the expression of cyclin D1 when given cold shock, and therefore reduce cell proliferation in suboptimal conditions; 4) Hsp70 is not regulated in response to cold shock in these crabs but is modulated by acclimation temperature. This study compliments our previous work that showed that the two populations differ in their upper organismal and cellular thermotolerance and highlights an additional mechanism by which the physiological phenotype may be diverging across the invaded range.

\section{Thermotolerance as a predictor of range expansion}

Two criteria must be met in order for invasive organisms to establish a viable population during range expansion: 1) Larvae (propagules) must have the capacity to tolerate abiotic conditions present in the novel environment and transition into adults and 2) adults must be able to endure seasonal abiotic variation year-round and eventually reproduce. Previous experiments found that the thermotolerance of $C$. maenas larvae from California was sufficient to withstand summer temperatures well into Alaska (de Rivera et al. 2007). These data, coupled with our adult thermotolerance capacity experiments, demonstrate the aptitude of this species to tolerate thermal conditions year-round beyond their current range limits at these northern sites. This finding complements niche modeling (de Rivera et al. 2006) that suggest this population of C. maenas is 
thermally capable of year round establishment beyond its current range limit. Furthermore, they also suggest poleward expansion of the BC population of $C$. maenas will not be limited by the lower temperatures to the north. Moreover, larvae from Vancouver Island, BC have been shown to be capable of dispersing past Sitka, AK, under both normal and El Niño conditions (Therriault et al. 2008)

Combined with the results of the cold tolerance experiment (crabs held for 18 weeks at or below $5^{\circ} \mathrm{C}$ ), the winter (January-March 2009) thermal contour map of the Gulf of Alaska (http://www.nodc.noaa.gov/cgibin/OC5/SELECT/woaselect.pl) suggests that the adult Carcinus thermogeographic range could potentially stretch to Cordova, AK (Fig. 3.5). Of course, thermotolerance alone does not predict range expansion as propagule supply and a variety of biotic and abiotic factors influence establishment success. However, Compton et al. (2010) found that among abiotic variables, including temperature, salinity, chlorophyll concentration and wave exposure, temperature was overwhelmingly the top predictor of invasion success in this species. 


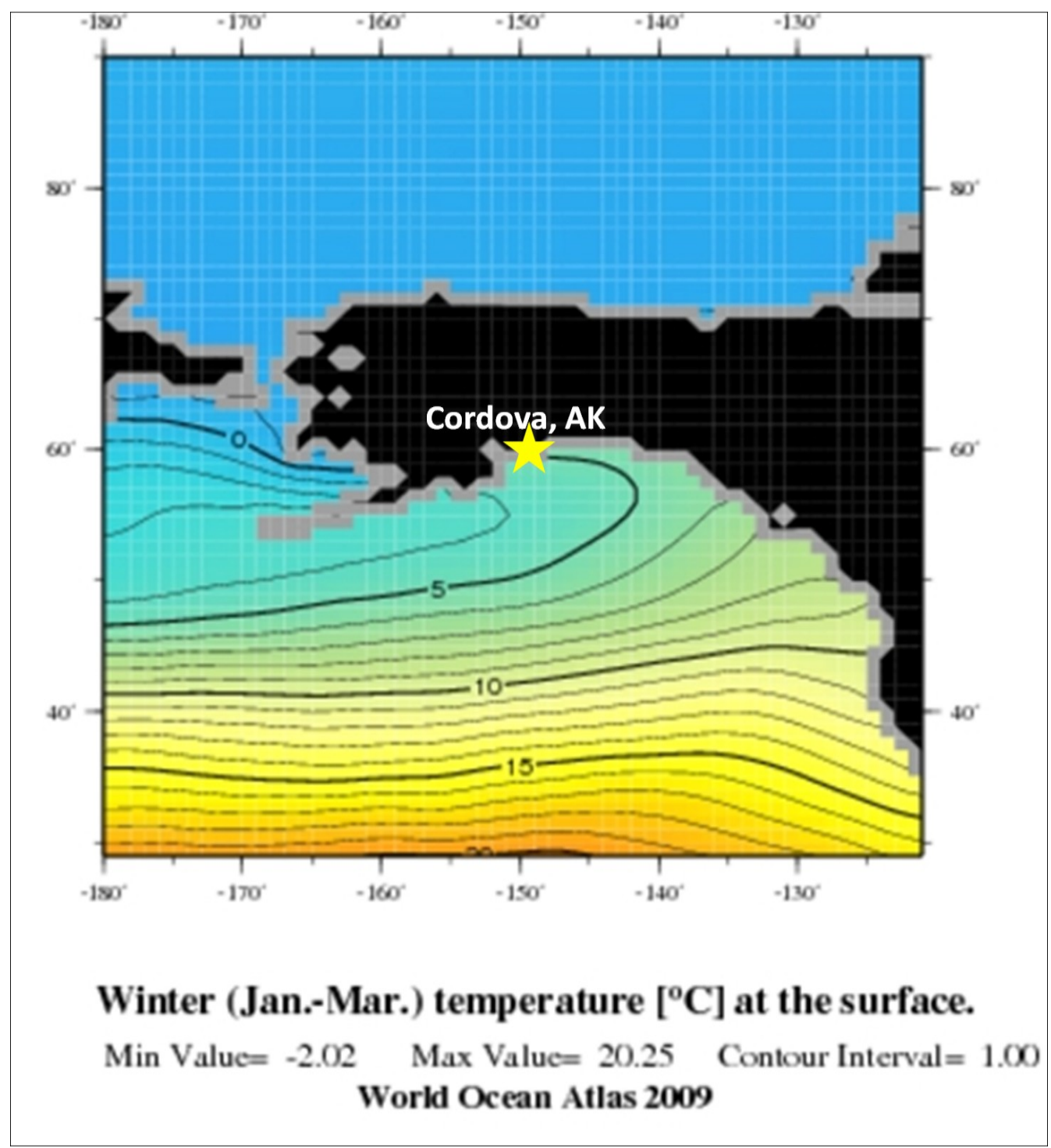

FIGURE 3.5 THERMOGEOGRAPHIC CONTOUR MAP OF AVERAGE SEA SURFACE TEMPERATURES FROM JANUARY THROUGH MARCH 2009 (HTTP://WWW.NODC.NOAA.GOV/CGI-BIN/OC5/SELECT/WOASELECT.PL). WHOLE ANIMAL COLD TOLERANCE CAPACITY GENERATED FROM SITKA, AK DEMONSTRATES THAT CRABS SAMPLED FROM PIPESTEM INLET, BC ARE THERMALLY CAPABLE OF OVERWINTERING OUTSIDE OF THEIR CURRENT RANGE, AS FAR NORTH AS CORDOVA, AK.

The marine environment is currently under a state of rapid change due to the impacts of anthropomorphic atmospheric $\mathrm{CO}_{2}$ emissions on the earth's climate (Pörtner 2002a, Pörtner et al. 2004, Roessig et al. 2004, Pörtner et al. 
2005, Parmesan 2006). Already a poleward shift in species range boundaries of $6.1 \mathrm{~m}$ per decade is identifiable in the Northern hemisphere (Parmesan 2006). Marine ectotherms are especially sensitive to changes in environmental temperature due to its effect on biochemical processes, which is a major factor in governing geographic distribution within a given environment (Somero 2002, 2005). The most conservative model released by the Intergovernmental Panel on Climate Change (IPCC) forecasts an average increase of $1.8^{\circ} \mathrm{C}$ in sea surface temperature by the year 2100 (Meehl et al. 2007). Given our whole organism cold tolerance data, the C. maenas thermogeographic range under this scenario would extend past the Aleutian Islands, into the Bering Sea (Fig 3.6). 


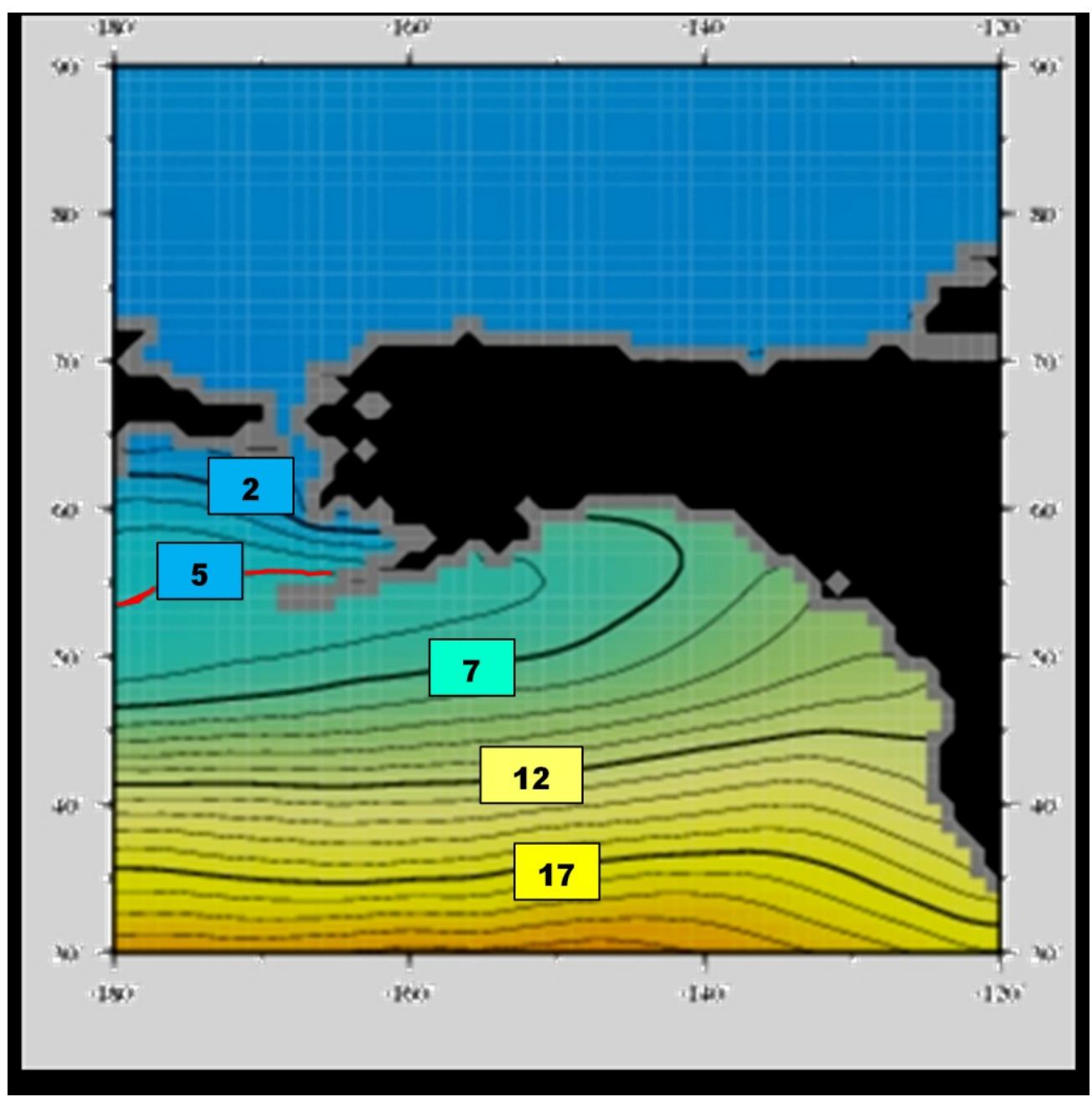

Figure 3.6 THERMOGEOGRAPHIC CONTOUR MAP OF AVERAGE SEA SURFACE TEMPERATURES WITH $1.8^{\circ} \mathrm{C}$ ADDED TO THE PROFILE, REFLECTING PROJECTIONS OF THE IPCC SRES B2 SCENARIO. WHOLE ANIMAL COLD TOLERANCE CAPACITY GENERATED FROM SITKA, AK DEMONSTRATES THAT CRABS SAMPLED FROM PIPESTEM INLET, BC ARE THERMALLY CAPABLE OF OVERWINTERING OUTSIDE OF THEIR CURRENT RANGE, AS FAR NORTH AS CORDOVA, AND INTO THE BEARING SEA, GIVEN THIS GLOBAL WARMING SCENARIO.

Under the least sustainable A1F1 scenario, an increase of $4^{\circ} \mathrm{C}$, their thermogeographically acceptable range would expand to include Bristol Bay, AK and cross the eastern Pacific to parts of northern Russia. Under any IPCC scenario, the predicted thermal shift will undoubtedly open previously unreachable environments to invasion. 


\section{Regulation of cyclin D1 in response to cold stress}

The modulation of cell proliferation is an integral part of the maintenance of cellular homeostasis (Resnitzky and Reed 1995, Fu et al. 2004). The cold induced signal transduction pathway WAF1 has been shown to be involved in the repression of cyclin D1 synthesis through the modification of the E2F transcription factor, whose hyperphosphorylation is responsible for continuous synthesis of cyclin D1 through a positive feed-back loop (Ohnishi et al. 1998). Here, we found cyclin D1 was modulated in response to cold shock and its expression varied across populations with different thermal profiles in response to different scales of thermal history (short-term ramp down, medium-term lab acclimation, and long-term population thermal histories). The site-specific variation in cyclin D1 expression given cold shock suggests that the $B C$ population differs in key aspects of its cellular stress response compared to the CA population (Fig. 3.3). The BC group's ability to down-regulate a key factor involved in cell cycle progression may demonstrate that this population initiates one aspect of the CSR due to cold shock while the CA crabs did not significantly alter their cyclin $\mathrm{D} 1$ levels when given cold shock following $6^{\circ} \mathrm{C}$ acclimation (Fig 3.3).

The control treatments (no ramp down) illustrate the role of acclimation temperature on cyclin D1 expression. For both the $\mathrm{BC}$ and $\mathrm{CA}$ groups, $6^{\circ} \mathrm{C}$ acclimation produced the greatest expression of cyclin D1, implying that this lower temperature may be more amenable to cyclin D1 expression than the $23^{\circ} \mathrm{C}$ 
acclimation (Fig. 3.3). The lower levels of cyclin D1 produced by $23^{\circ} \mathrm{C}$ controls suggest that $23^{\circ} \mathrm{C}$ is too warm for cell cyclin D1 synthesis for either population when compared to the cyclin $\mathrm{D} 1$ levels expressed by both populations at the $6^{\circ} \mathrm{C}$ acclimation treatment.

Cyclin D1 expression in the context of niche conservatism

Physiological measurements could be used to test for thermal niche conservatism, defined as the tendency of species to retain ancestral ecological characteristics (Wiens and Graham 2005), within an invasive population. The ancestral thermal niche is often regulated by the genotype of the founding individuals, which in this case is the southern European haplotype (Darling et al. 2008). Previous work suggests that the native southern haplotype can be characterized by average summer temperatures of $15^{\circ} \mathrm{C}$, and winter temperatures of $6-8^{\circ} \mathrm{C}$ (Compton et al. 2010), nearly identical to the thermal conditions of the BC population (Kelley et al. 2011). Therefore, given the niche conservatism hypothesis, we would expect that a population derived from the southern native haplotype of C. maenas would likely produce greater amounts of cyclin D1 at temperatures similar to its ancestral thermal niche. Our data here on lower thermotolerance and also our previous data on upper thermotolerance (Kelley et al. 2011) are consistent with this idea.

The relationship between cell cycle regulation and the heat shock response

The cellular stress response utilizes a conserved set of signal transduction pathways that modulate genes that govern cell-cycle activity, DNA synthesis and 
repair, protein chaperoning, and ubiquitination of defunct proteins/pro apoptotic pathways (Kültz 2003, 2005). When cells experience thermal stress, the stress proteome temporarily extends tolerance limits by several different mechanisms, including up-regulating protein chaperones such as Hsp70 (Cox et al. 1993, Holland et al. 1993, Laios et al. 1997, Feder and Hofmann 1999, Fink 1999, Fujita 1999, Ali et al. 2003) and initiating reversible cell-cycle arrest (Nitta et al. 1997, Ohnishi et al. 1998). Our results are congruent with this assessment (Fig. 3.8). 

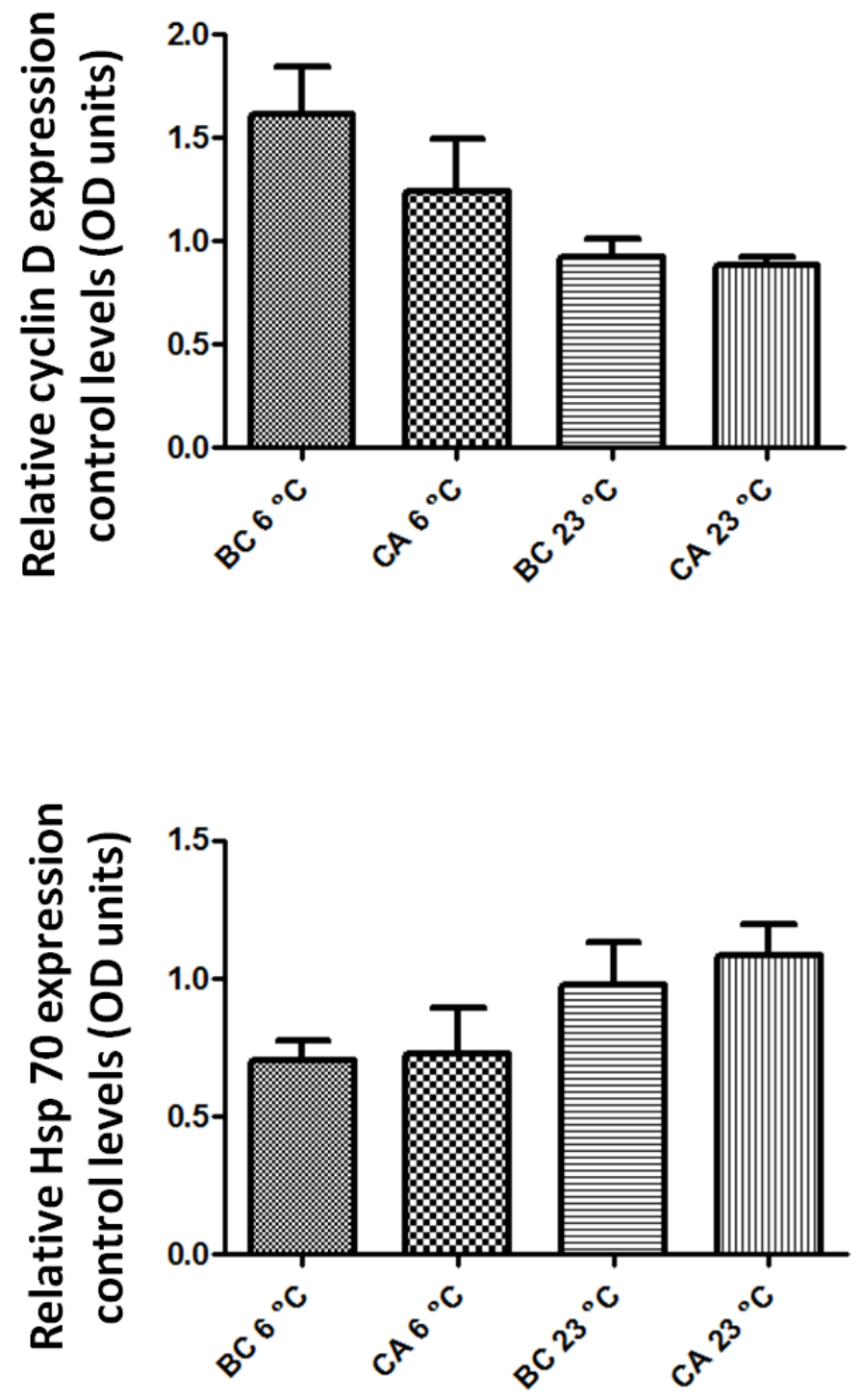

FIGURE 3.7 RELATIVE CONTROL LEVELS OF CYCLIN D1 AND HSP70 IN C. MAENAS AFTER LAB ACCLIMATION OF 6 AND $23^{\circ} \mathrm{C}$ RESPECTIVELY; BARS SHOW MEAN $\pm 1 \mathrm{SE}$.

The $\mathrm{BC}$ group acclimated to $6^{\circ} \mathrm{C}$ displayed the greatest expression of cyclin $\mathrm{D} 1$ and the least amount of Hsp70. As the levels of cyclin D1 decline, the Hsp70 level increases in a complementary fashion, with the $\mathrm{CA} 23^{\circ} \mathrm{C}$ acclimation group expressing the greatest amount of Hsp70 and the least amount of cyclin D1. 
These differences however were not statistically significant (Fig. 3.8). Hence, these results suggest that there may be an inverse correlation between cyclin D1 expression and the induction of protein chaperones under potentially stressful thermal conditions, which provides anecdotal evidence in support of the hypothesized CSR model. Previous observations of site-specific variation in organismal upper thermal tolerance limits and Hsp70 regulation (Kelley et al. 2011) and the site-specific differences in expression of a key regulator of cell proliferation at different acclimation temperatures measured here support the hypothesis that colder temperatures will not be a barrier to expansion to higher latitudes and, in fact, may favor cell growth and proliferation in this invasive species. Finally, measuring the effect of acclimation can be used to compare populations from disparate environments, potentially highlighting differences in ability to survive in more extreme conditions, including new areas. In this case, it can be used to elucidate the temperatures most conducive to cell proliferation.

It is clear that successfully invading species, due to phenotypic plasticity or rapid adaptation, can alter their cellular physiology to tolerate conditions that would be stressful to other populations. Site-specific physiological measurements can be integrated with modeling to provide improved insights into potential range expansion for invading species as well as species shifting range due to changing environmental conditions. 


\section{CHAPTER FOUR: BIOGEOGRAPHIC VARIATION IN BODY SIZE IN THE INVASIVE CARCINUS MAENAS ON THE WEST COAST OF NORTH AMERICA: DOES THE GREEN CRAB FOLLOW THE TEMPERATURE- SIZE RULE FOR ECTOTHERMS?}

\section{Introduction}

Broad variations in life history traits, including growth, fecundity, sex ratios and adult body size, can be attributed in part to variations in the environments that organisms inhabit (Pigliucci 2001). The spectrum of expression of these traits is a product of additive genetic variation and phenotypic plasticity; the latter being a direct response to environmental selective pressures that result in different phenotypes (Pigliucci 2001). Phenotypic differences in adult size across an environmental gradient can be explained by variations in biotic and abiotic pressures, such as predation pressure (Riessen 1999), resource availability (Chase 1999), and ambient temperature (Atkinson 1994, Atkinson 1996, Partridge and Coyne 1997, Angilletta and Dunham 2003, Atkinson et al. 2003). The trait of body size is ecologically relevant because it has the capacity to influence many aspects of an organism's biology including physiology, behavior, anatomy, and reproduction (Naganuma and Roughgarden 1990).

For ectotherms in particular, temperature is one of the most influential forces that govern organismal growth and larval development, and variations in temperature across a species range may result in a phenotypic spectrum of adult 
body size (Partridge and French 1996). Reviews of laboratory studies have shown that, for a majority of ectotherms studied, organisms reared at low temperatures attain larger body size, despite growing at a slower rate, than conspecifics reared at warmer temperatures (Atkinson 1994, Atkinson 1996, Atkinson and Sibly 1997, Partridge and Coyne 1997, Angilletta and Dunham 2003, Atkinson et al. 2003). Such a thermal response of body size in ectotherms due to phenotypic plasticity is referred to as the temperature size rule. Thermally driven latitudinal variations in body size have been found in temperate crabs (Shirley et al. 1987, Hines 1989) and other taxa as well (Blackburn et al. 1999, Ashton 2004). Moreover, much attention has been given to this biological rule as global climate change, specifically increases in atmospheric temperature, have resulted in a reduction of body size across taxa (Gardner et al. 2011, Sheridan and Bickford 2011). The physiological mechanisms governing this rule are poorly understood and no broadly applicable mechanism generating it has been supported (Angilletta and Dunham 2003, Walters and Hassall 2006).

For invasive species in particular, body size in invaded ranges is often larger than in their native ranges, especially for marine organisms (Torchin et al. 2001, Grosholz and Ruiz 2003). Attaining larger body size can be beneficial to invading organisms and could potentially improve their colonization success and increase their impacts to recipient areas (Hone and Benton 2005). If the recipient environment is slightly colder than the donor one, this temperature difference 
also could influence body size. The introduction of non-native species can offer natural experiments for exploring the temperature-size rule of ectotherms.

A study of two populations of the invasive crab Carcinus maenas found crabs from the northern edge of their recipient range along the west coast of North America were significantly larger than ones sampled near the southern range edge (Kelley et al. 2011). Because only two sites were studied, it is unclear whether the size difference provides sufficient evidence of the temperature sizerule occurring in the short time-span of this invasion. Carcinus maenas, the European green crab, is native to Europe and North Africa, but has successfully invaded multiple temperate regions globally (Cohen et al. 1995). The northeastern Pacific population of C. maenas quickly spread northward from its entry point of San Francisco Bay; it most recently invaded Gales Passage, British Columbia, extending its range to mainland Canada (Cohen et al. 1995, Behrens Yamada and Hunt 2000, Gillespie et al. 2007). Only one haplotype has been found throughout this range, indicating a high degree of genetic similarity across the metapopulation (Darling et al. 2008, Tepolt et al. 2009). Previous studies on this metapopulation of Carcinus maenas have identified site-specific differential expression of several key proteins involved in the regulation of cellular thermotolerance, including Hsp70 (Kelley et al. 2011), cell cycle modulation via the repression of cyclin D1(Kelley et al. 2013), as well as organismal thermal tolerance thresholds, highlighting the role that environmental temperature has 
played in driving the physiologic variation in phenotype that currently exists across this recipient range (Kelley et al. 2011).

Over the course of the 24 years since its initial northeastern Pacific invasion, research has characterized the genetic architecture of this population (Darling et al. 2008, Tepolt et al. 2009), the effect of temperature on larval development and survival rates (de Rivera et al. 2007), and variation in population demographics between the native and invasive ranges (McGaw et al. 2011). Furthermore, morphological and ecological data were gathered frequently from 10 sites spanning the northeast Pacific metapopulation. Hence, we can build on this solid foundation and examine the influence of ecological factors on the phenotypic trajectory of invasive organisms. We aim to gain a greater understanding of the processes and mechanisms involved in the biogeographic evolution of phenotypes within and across spatio-temporal scales.

In this study, we investigated the pattern of carapace width, hereafter, CW (body size), variation of Carcinus maenas along $13^{\circ}$ latitude on the west coast of North America (Fig.4.1). This range represents a $5-10^{\circ} \mathrm{C}$ difference in temperature, depending on time of year (Kelley et al. 2011). We examined whether the variation in $\mathrm{CW}$ conformed to the temperature-size rule for ectotherms. Specifically, we tested the hypotheses that adult CW was positively correlated with latitude and negatively correlated with environmental temperature. 
Our results generally supported the temperature-size rule for ectotherms. For both the invasive west coast North American metapopulation and the native European metapopulation, temperature was significantly correlated to the trait of adult body size in this species. Both metapopulations exhibited a larger $\mathrm{CW}$ at the northern end of their respective ranges, and smaller CW was correlated with the warmer temperatures experienced at the southern portion of their ranges.

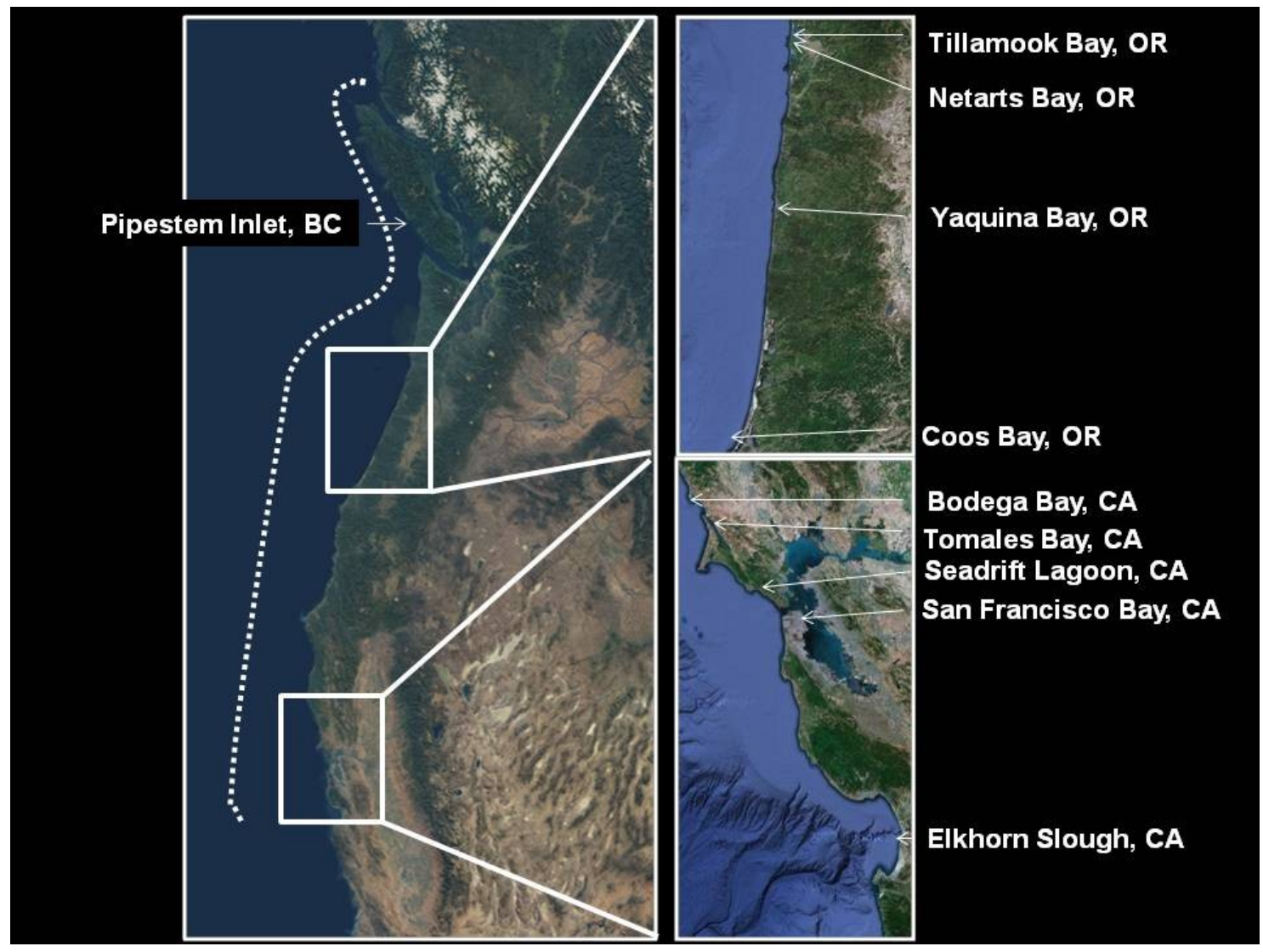

FIGURE 4. 1 THE CURRENT DISTRIBUTION OF CARCINUS MAENAS ON THE WEST COAST OF NORTH AMERICA, FROM ELKHORN SLOUGH, CALIFORNIA, TO GALES PASSAGE, BRITISH COLUMBIA MAINLAND. SAMPLE SITES FOR THIS STUDY ARE MARKED WITH AN ARROW.

\section{Materials and methods}


We used data for all sites along the west coast of the North America that had consistently collected crab data for over five years leading up to 2010. From north to south, the breadth of the sample sites represents $13^{\circ}$ latitude, with Elkhorn Slough, CA representing the most southern site at $36^{\circ} \mathrm{N}$, and Pipestem Inlet, British Columbia being the most northern site in this study at $49^{\circ} \mathrm{N}$ latitude (Fig. 4.1, Table 4.1). 
Sample site, temperature logger, sample date range, and mean temperature $\left({ }^{\circ} \mathrm{C}\right)$

\begin{tabular}{|c|c|c|c|c|}
\hline Sample site & Data acquisition & $\begin{array}{l}\text { Sampling } \\
\text { date range }\end{array}$ & $\begin{array}{c}\text { Mean } \\
\text { temperatu } \\
\text { re }{ }^{\circ} \mathrm{C}\end{array}$ & Reference \\
\hline $\begin{array}{l}\text { Pipestem Inlet, } \\
\text { British Columbia }\end{array}$ & $\begin{array}{c}\text { Canadian } \\
\text { DFO Amphrite Point } \\
\text { lighthouse }\end{array}$ & $2005-2010$ & 10.58 & $\begin{array}{c}\frac{\text { http://www.pac.dfo- }}{\text { mpo.gc.ca/science/ocea }} \\
\underline{\text { ns/data- }} \\
\frac{\text { donnees/lighthouses- }}{\text { phares/index-eng.htm }}\end{array}$ \\
\hline $\begin{array}{l}\text { Tillamook Bay, } \\
\text { Oregon }\end{array}$ & $\begin{array}{l}\text { NOAA NOS Buoy, } \\
\text { Station ID: } 9437540\end{array}$ & $2006-2010$ & 11.18 & $\frac{\text { http://www.ndbc.noaa.go }}{\text { v/download data }}$ \\
\hline $\begin{array}{l}\text { Netarts Bay, } \\
\text { Oregon }\end{array}$ & $\begin{array}{c}\text { Mean of Tillamook and } \\
\text { Yaquina Bays }\end{array}$ & $2006-2010$ & 11.24 & $\mathrm{~N} / \mathrm{A}$ \\
\hline $\begin{array}{l}\text { Yaquina Bay, } \\
\text { Oregon }\end{array}$ & $\begin{array}{l}\text { NOAA NOS Buoy, } \\
\text { Station ID: } 9435380\end{array}$ & $2006-2010$ & 11.29 & $\frac{\text { http://www.ndbc.noaa.go }}{\text { v/download data }}$ \\
\hline $\begin{array}{l}\text { Coos Bay, } \\
\text { Oregon }\end{array}$ & $\begin{array}{l}\text { NOAA NOS Buoy, } \\
\text { Station ID: } 9432780\end{array}$ & $2006-2010$ & 11.31 & $\frac{\text { http://www.ndbc.noaa.go }}{\text { v/download data }}$ \\
\hline $\begin{array}{l}\text { Fort Point, } \\
\text { Bodega Bay, } \\
\text { California }\end{array}$ & $\begin{array}{l}\text { Bodega Ocean } \\
\text { Observing Node }\end{array}$ & $2008-2010$ & 13.2 & $\frac{\frac{\text { http://bml.ucdavis.edu/bo }}{\text { on/data seawater temp }}}{\underline{\text { erature.html }}}$ \\
\hline $\begin{array}{l}\text { Tomales Bay, } \\
\text { California }\end{array}$ & $\begin{array}{l}\text { Tomales Bay water } \\
\text { quality monitoring, } \\
\text { Lagunitas Creek }\end{array}$ & $2008-2010$ & 14.79 & $\frac{\frac{\text { http://www.tomalesbayw }}{\text { atershed.org/wqdocs/FIN }}}{\frac{\text { AL 2009 10 TBWC An }}{\text { nualWQReport.pdf }}}$ \\
\hline $\begin{array}{l}\text { Sea Drift } \\
\text { Lagoon, } \\
\text { California }\end{array}$ & $\begin{array}{l}\text { Mean of Tomales Bay } \\
\text { and San Francisco Bay }\end{array}$ & $2008-2010$ & 15.22 & $\mathrm{~N} / \mathrm{A}$ \\
\hline $\begin{array}{l}\text { San Francisco } \\
\text { Bay, California }\end{array}$ & $\begin{array}{l}\text { NERRS Water Quality } \\
\text { Station: SCQC1, China } \\
\text { Beach }\end{array}$ & $2006-2010$ & 15.66 & $\frac{\text { http://www.ndbc.noaa.go }}{\text { v/download data }}$ \\
\hline $\begin{array}{l}\text { Elkhorn Slough, } \\
\text { California }\end{array}$ & $\begin{array}{l}\text { NERRS Water Quality } \\
\text { Station: South Marsh }\end{array}$ & $2006-2010$ & 15.44 & $\frac{\text { http://cdmo.baruch.sc.ed }}{\underline{\mathrm{u} /}}$ \\
\hline
\end{tabular}

TABLE 4.1 LISTS THE SAMPLE SITE, TEMPERATURE LOGGER TYPE, CRAB SAMPLING RANGE, MEAN TEMPERATURE, AND REFERENCE FOR THE TEMPERATURE DATA. 
The sampling protocol was similar across sample sites. Collapsible fish traps were deployed at least annually in the shallow subtidal to low intertidal. Traps were checked, emptied, and rebaited every 24 hours for two to three consecutive days. Collapsible fish traps $(63 \times 46 \times 23 \mathrm{~cm} ; 1.6 \mathrm{~cm}$ mesh; from Fukui) were used at all sites and were set in lower intertidal to shallow subtidal waters. In Oregon, where catch was quite low, we also used data from minnow traps. These were modified to have slightly larger $(\sim 4 \mathrm{~cm})$ openings and were set in the mid littoral.

All trapped intermolt male and female Carcinus maenas were measured. Carapace width $(\mathrm{CW})$, using calipers, and sex were recorded. The carapace width was taken between the outside of the outermost spines (California and Oregon data) or the notches just inside the outermost spines (British Columbia data), or both. The two width measurements are tightly correlated $\left(r^{2}=0.9954\right.$, Gillespie et al. 2007). When CW measurements were taken from notch-to-notch, the point-to-point measurements were calculated using the regression equation: $C W_{\text {notch-to-notch }}=0.9095\left(C W_{\text {point-to-point }}\right)+0.4816$ following Gillespie $(2007)$.

To minimize the effects of frequency and timing of recruitment on the carapace width of crabs in each site, we used at least five years of size data per site (Table 4.1) and excluded juvenile crabs. Carcinus maenas has a life span of roughly 4-6 years (Broekhuysen 1936, Berrill 1982). Therefore, the sampling period for each site included one life cycle of the study species. Hence, the 
influence of strong recruitment, the frequency of which may have a latitudinal trend, should have less impact on the overall five-year $\mathrm{CW}$ value for each site.

To further reduce any influence of recruitment and to ensure the inclusion of only adults in this analysis, all crabs that fell below a threshold of $45 \mathrm{~mm}$ were excluded from analysis. This type of $\mathrm{CW}$ truncation has been used to exclude juvenile crabs in similar studies (Burmeister and Sainte-Marie 2010). This threshold, $45 \mathrm{~mm}$, was chosen because it is the smallest recorded measurement for berried adult females at these sites (except for 1 female from BC), signifying sexual maturity.

\section{Thermogeographic data}

Table 4.1 lists the sample site, source of the temperature data, years of data collection, and the calculated mean temperature. While the method in which temperature data were sampled varied between sites, these data were typically collected each year that crabs were sampled. We calculated the mean (5 years of data where available) of the yearly means, which standardized across sites and years with different amounts of data. The mean temperature value for each site corresponded to the years crabs were sampled (Table 4.1). For temperature values measured at NOAA OOS buoys, yearly means from hourly temperature recordings were generated after removing missing and anomalous readings (beyond the scope of what was to be expected for that time of year, 999 eg.) from the datasets. The mean temperature for Netarts Bay, OR and Sea Drift Lagoon, $\mathrm{CA}$ were generated using the mean $\left(\mathrm{C}^{\circ}\right)$ of the sites above and below 
these sites rather than right in the sampling bay or lagoon itself, as there was no yearly temperature data for these sites (italicized in Table 4.1).

Literature review of carapace width from native range

In an effort to discern whether a relationship between $\mathrm{CW}$ and temperature could be detected in the native range, an extensive literature review was conducted where maximum CW, sample site, sample size, sample year, and sex were recorded. Temperature data for the latitude and longitude of the sample $\begin{array}{llll}\text { sites } & \text { were } & \text { extracted } & \text { from }\end{array}$ (http://www.oracle.ugent.be/, http://oceancolor.gsfc.nasa.gov/), which yielded a mean sea surface temperature for each site (spatial resolution $9.2 \mathrm{~km}$ ), Table 4.2. 


\begin{tabular}{|c|c|c|c|c|c|}
\hline \multicolumn{6}{|c|}{$\begin{array}{l}\text { Publish Carapace widths for Carcinus maenas from different latitudes with the } \\
\text { corresponding mean temperature }\left({ }^{\circ} \mathrm{C}\right) \text { and } \max \mathrm{CW}(\mathrm{mm})\end{array}$} \\
\hline Latitude & Longitude & $\begin{array}{l}\text { Site and date } \\
\text { collected }\end{array}$ & $\begin{array}{l}\text { Max } \\
\text { CW- } \\
\mathrm{mm}\end{array}$ & Citation & SST mean \\
\hline $40^{\circ} 38^{\prime} 28.13^{\prime \prime} \mathrm{N}$ & $8^{\circ} 45^{\prime} 28.57^{\prime \prime W}$ & Ria de Aveiro, Portugal & 62 & Coelho, 2008 & 15.771 \\
\hline $41^{\circ} 52^{\prime 2} 24.94 " \mathrm{~N}$ & $8^{\circ} 50^{\prime} 52.93 " \mathrm{~W}$ & Caminha, Portugal & 65 & Souza, 2011 & 15.341 \\
\hline $41^{\circ} 88^{\prime} 41.46 " \mathrm{~N}$ & $8^{\circ} 40^{\prime} 11.35^{\prime \prime W}$ & $\begin{array}{l}\text { Mondego estuary, } \\
\text { Portugal }\end{array}$ & 57 & Coelho, 2008 & 15.557 \\
\hline $50^{\circ} 21^{\prime} 20.26 " \mathrm{~N}$ & $4^{\circ} 7^{\prime} 46.01 " \mathrm{~W}$ & $\begin{array}{l}\text { Mountbatten, Plymouth } \\
\text { UK, } 2005\end{array}$ & 65 & $\begin{array}{l}\text { Spooner et al., } \\
2007\end{array}$ & 12.266 \\
\hline $50^{\circ} 15^{\prime} 40.25^{\prime \prime} \mathrm{N}$ & $3^{\circ} 52^{\prime} 6.35^{\prime \prime} \mathrm{W}$ & $\begin{array}{c}\text { Portwrinkle- } \\
\text { Thurlestone, UK, } \\
<2010\end{array}$ & 70 & Silva et al., 2010 & 12.431 \\
\hline $50^{\circ} 21^{\prime} 21.63^{\prime \prime} \mathrm{N}$ & $4^{\circ} 8^{\prime} 31.56 " \mathrm{~W}$ & Plymouth, UK, <1931 & 57 & Huxley, 1931 & 12.266 \\
\hline $51^{\circ} 42^{\prime} 47.15^{\prime \prime} \mathrm{N}$ & $5^{\circ} 9^{\prime} 44.67 " \mathrm{~W}$ & $\begin{array}{l}\text { Dale Roads, Wales, } \\
\text { UK, 1964-1966 }\end{array}$ & 70 & Crothers, 1968 & 11.896 \\
\hline $51^{\circ} 44^{\prime} 34.00^{\prime \prime} \mathrm{N}$ & $1^{\circ} 0$ '12.39"E & Essex, UK, <1931 & 62 & Huxley, 1931 & 12.282 \\
\hline $51^{\circ} 37^{\prime} 51.64^{\prime \prime} \mathrm{N}$ & $3^{\circ} 50^{\prime} 46.46 " \mathrm{E}$ & $\begin{array}{l}\text { Oosterschelde, } \\
\text { Netherlands, } 2003\end{array}$ & 63 & $\begin{array}{l}\text { Kamermans, } \\
2009\end{array}$ & 12.174 \\
\hline $53^{\circ} 16^{\prime} 50.60^{\prime \prime} \mathrm{N}$ & $4^{\circ} 2^{\prime} 33.64^{\prime \prime W}$ & $\begin{array}{c}\text { Menai Straights, } \\
\text { Anglesey, UK, }<1978\end{array}$ & 75 & Elner, 1978 & 11.563 \\
\hline $53^{\circ} 38^{\prime} 25.35^{\prime \prime} \mathrm{N}$ & $6^{\circ} 20^{\prime} 36.24 " \mathrm{E}$ & $\begin{array}{l}\text { Dutch Wadden Sea, } \\
\text { Netherlands } 1963-64\end{array}$ & 70 & $\begin{array}{c}\text { Creutzberg and } \\
\text { Fonds, } 1971\end{array}$ & 11.404 \\
\hline $53^{\circ} 16^{\prime} 50.60^{\prime \prime} \mathrm{N}$ & $4^{\circ} 2^{\prime} 33.64^{\prime \prime W}$ & $\begin{array}{l}\text { Menai Strait, Wales, } \\
<1987\end{array}$ & 70 & $\begin{array}{l}\text { Ameyaw- Akumfi, } \\
1987\end{array}$ & 11.563 \\
\hline $53^{\circ} 40^{\prime} 50.95^{\prime \prime} \mathrm{N}$ & $8^{\circ} 20^{\prime} 23.29 " \mathrm{E}$ & $\begin{array}{l}\text { German Wadden Sea, } \\
<1998\end{array}$ & 71 & Wolf, 1998 & 11.674 \\
\hline $53^{\circ} 16^{\prime} 50.60^{\prime \prime} \mathrm{N}$ & $4^{\circ} 2^{\prime} 33.64^{\prime \prime W}$ & $\begin{array}{l}\text { Menai Strait, UK, } \\
<1979\end{array}$ & 70 & Hughes, 1979 & 11.563 \\
\hline $53^{\circ} 19^{\prime} 42.31^{\prime \prime} \mathrm{N}$ & $3^{\circ} 48^{\prime} 40.08^{\prime \prime W}$ & $\begin{array}{c}\text { Llandudno and } \\
\text { Conway, North Wales, } \\
\text { UK, 1965-67 }\end{array}$ & 75 & Walne, 1972 & 11.1 \\
\hline $54^{\circ} 29^{\prime} 36.87^{\prime \prime} \mathrm{N}$ & $0^{\circ} 36^{\prime} 53.00 " \mathrm{~W}$ & $\begin{array}{c}\text { Whitby Harbour and } \\
\text { Robin Hoods Bay, UK, } \\
1973\end{array}$ & 79 & McVean, 1976 & 10.64 \\
\hline $54^{\circ} 28^{\prime} 15.05^{\prime \prime} \mathrm{N}$ & $14^{\circ} 10^{\prime} 45.25^{\prime \prime E}$ & Baltic Germany & 75 & $\begin{array}{c}\text { Dries and } \\
\text { Adelung, 1982, } \\
\text { Behrens- } \\
\text { Yamada, 2005 }\end{array}$ & 10.082 \\
\hline $54^{\circ} 25^{\prime} 18.53^{\prime \prime} \mathrm{N}$ & $0^{\circ} 31 ' 21.54 " \mathrm{~W}$ & $\begin{array}{l}\text { Boggle Hole, UK, } \\
<2009\end{array}$ & 75 & Fletcher, 2009 & 10.447 \\
\hline $55^{\circ} 44^{\prime} 14.37^{\prime \prime} \mathrm{N}$ & $4^{\circ} 55^{\prime} 12.48^{\prime \prime W}$ & $\begin{array}{l}\text { Millport, Isle of Cumbra } \\
1996\end{array}$ & 80 & Sneddon, 1997 & 10.823 \\
\hline $55^{\circ} 44^{\prime} 14.37^{\prime \prime N}$ & $4^{\circ} 55^{\prime} 12.48 " \mathrm{~W}$ & $\begin{array}{l}\text { Millport, Scotland, } \\
<1970\end{array}$ & 80 & Heath, 1970 & 10.823 \\
\hline $55^{\circ} 26^{\prime} 56.97 " \mathrm{~N}$ & $10^{\circ} 40^{\prime} 22.66^{\prime E}$ & $\begin{array}{l}\text { Kerteminde Fjord, } \\
\text { Denmark }\end{array}$ & 81 & Abuello,1997 & 9.842 \\
\hline
\end{tabular}




\begin{tabular}{|c|c|c|c|c|c|}
\hline $55^{\circ} 38^{\prime} 33.13^{\prime \prime} \mathrm{N}$ & $12^{\circ} 50^{\prime} 22.14 " \mathrm{E}$ & $\begin{array}{c}\text { Orensund, Denmark, } \\
<2004\end{array}$ & 80 & Garm, 2005 & 9.871 \\
\hline $55^{\circ} 38^{\prime} 33.13^{\prime \prime} \mathrm{N}$ & $12^{\circ} 50^{\prime} 22.14 " \mathrm{E}$ & $\begin{array}{c}\text { Odense Fjord, } \\
\text { Denmark, <1994 }\end{array}$ & 80 & $\begin{array}{c}\text { Pedersen et al., } \\
1994\end{array}$ & 9.871 \\
\hline $56^{\circ} 48^{\prime} 50.68^{\prime \prime} \mathrm{N}$ & $10^{\circ} 42^{\prime} 0.23^{\prime \prime E}$ & Kattegat, Denmark & 92 & $\begin{array}{c}\text { Rassmussen, } \\
\text { 1973, Munch- } \\
\text { Petersen, 1982, } \\
\text { Behrens- } \\
\text { Yamada, 2005 } \\
\end{array}$ & 10.25 \\
\hline $58^{\circ} 24^{\prime} 7.98^{\prime \prime N}$ & $11^{\circ} 35^{\prime} 18.65^{\prime \prime E}$ & $\begin{array}{l}\text { Gullmarsfjorden, } \\
\text { Sweden }\end{array}$ & 100 & $\begin{array}{c}\text { Erickson and } \\
\text { Edlund, 1977, } \\
\text { Behrens- } \\
\text { Yamada, } 2005\end{array}$ & 8.849 \\
\hline $58^{\circ} 24^{\prime} 7.98^{\prime \prime N}$ & $11^{\circ} 35^{\prime} 18.65^{\prime \prime E}$ & $\begin{array}{c}\text { Gullmarsfjorden, } \\
\text { Sweden, } 1997,1999, \\
2000\end{array}$ & 75 & Werner, 2001 & 8.849 \\
\hline $60^{\circ} 34^{\prime} 16.69^{\prime \prime} \mathrm{N}$ & $4^{\circ} 57^{\prime} 27.15 " \mathrm{E}$ & $\begin{array}{c}\text { Island of Herdla, west } \\
\text { Norway, } 1985\end{array}$ & 80 & Sekkelsten, 1988 & 9.939 \\
\hline $60^{\circ} 34^{\prime} 16.69^{\prime \prime} \mathrm{N}$ & $4^{\circ} 57^{\prime} 27.15^{\prime \prime E}$ & $\begin{array}{c}\text { Island of Herdla, west } \\
\text { Norway, 1984-85 }\end{array}$ & $>80$ & $\begin{array}{c}\text { Van der } \\
\text { Meeren,1994 }\end{array}$ & 9.939 \\
\hline
\end{tabular}

TABLE 4. 2 LISTS THE SAMPLE SITE, LATITUDE AND LONGITUDE, SAMPLE SIZE, SEX, CITATION, AND MEAN SEA SURFACE TEMPERATURE.

\section{Statistical analysis}

All CW measurements from each site were pooled over the 5-year sampling period then CW data were separated by sex, as the species is sexually dimorphic (Broekhuysen 1936). Once juveniles (< $45 \mathrm{~mm} \mathrm{CW}$ ) were excluded, three CW size values were determined per sex: mean, mean-maximum (the average size of the largest $10 \%$ of the population), and maximum values. Mean maximum is a standard fisheries index that aims to estimate the upper average size of a given population (Jennings et al. 1999, McQuaid et al. 2000, Macpherson and Duarte 2006). Maximum, the largest CW measurement taken from each site over the entire sampling period, has also been used in examining a relationship between body size and latitude (Gilligan 1991, Grosholz and Ruiz 2003, Kelley et al. 2011). 
The CW values were correlated with latitude of the sample site and the corresponding mean temperature. Male groups met the assumption of normal distribution, so Pearson's correlation was used. Females, however, had some groups with small sample sizes and were not normally distributed, so Spearman's rank correlation was used in the analysis. To investigate the relationship between the native range and the west coast metapopulation's maximal $\mathrm{CW}$ and mean annual temperature, a linear regression was performed. Also, a linear regression was used to analyze the relationship between latitude and temperature along the invasive range.

\section{Results}

\section{CW across latitude}

Individuals of C. maenas were larger farther north (Fig. 4.3, Table 4.3). 


\begin{tabular}{|c|c|c|c|c|c|c|c|c|c|c|}
\hline \multicolumn{11}{|c|}{ Mean, mean max, and max values $(\mathrm{mm})$ and $(\mathrm{n})$ for each sample site } \\
\hline $\begin{array}{l}\text { Sex, } \\
\text { (n) }\end{array}$ & $\begin{array}{l}\text { Elkhorn } \\
\text { Slough }\end{array}$ & $\begin{array}{c}\text { San } \\
\text { Francisco } \\
\text { Bay }\end{array}$ & $\begin{array}{l}\text { Seadrift } \\
\text { lagoon }\end{array}$ & $\begin{array}{c}\text { Tomales } \\
\text { Bay }\end{array}$ & \begin{tabular}{|l|} 
Bod \\
ega \\
Bay
\end{tabular} & $\begin{array}{l}\text { Coos } \\
\text { Bay }\end{array}$ & $\begin{array}{c}\text { Yaquina } \\
\text { Bay }\end{array}$ & \begin{tabular}{|l|}
$\mathrm{Ne}$ \\
tarts \\
Bay
\end{tabular} & $\begin{array}{l}\text { Tilla } \\
\text { mook } \\
\text { Bay }\end{array}$ & \begin{tabular}{|c|} 
Pipe \\
stem Inlet
\end{tabular} \\
\hline $\begin{array}{c}\text { Male } \\
\text { Mean } \\
(n)\end{array}$ & $\begin{array}{c}69 \\
(247)\end{array}$ & $\begin{array}{l}64 \\
(82)\end{array}$ & $\begin{array}{c}60 \\
(1805)\end{array}$ & $\begin{array}{c}68 \\
(205)\end{array}$ & $\begin{array}{c}65 \\
(9120)\end{array}$ & $\begin{array}{c}76 \\
(131)\end{array}$ & $\begin{array}{c}76 \\
(168)\end{array}$ & $\begin{array}{c}70 \\
(105)\end{array}$ & $\begin{array}{l}69 \\
(33)\end{array}$ & $71(10519)$ \\
\hline $\begin{array}{l}\text { Mean } \\
\max (n)\end{array}$ & 85 (24) & $79(8)$ & $\begin{array}{c}73 \\
(180)\end{array}$ & $81(20)$ & $\begin{array}{c}80 \\
(912)\end{array}$ & $\begin{array}{c}92 \\
(13)\end{array}$ & $92(16)$ & \begin{tabular}{|l|}
94 \\
$(10)$
\end{tabular} & $89(3)$ & $89(1048)$ \\
\hline Max & 89 & 83 & 88 & 86 & 102 & 98 & 96 & 98 & 92 & 113 \\
\hline $\begin{array}{c}\text { Female } \\
\text { Mean } \\
(\mathrm{n})\end{array}$ & $\begin{array}{c}60 \\
(342)\end{array}$ & $\begin{array}{c}60 \\
(131)\end{array}$ & $\begin{array}{c}56 \\
(2472)\end{array}$ & $\begin{array}{r}59 \\
(87)\end{array}$ & $\begin{array}{c}55 \\
(2975)\end{array}$ & $\begin{array}{l}66 \\
(38)\end{array}$ & $\begin{array}{c}63 \\
(28)\end{array}$ & $\begin{array}{c}67 \\
(26)\end{array}$ & $\begin{array}{l}69 \\
(4)\end{array}$ & $\begin{array}{c}61 \\
(6141)\end{array}$ \\
\hline \begin{tabular}{|l} 
Mean \\
$\max (n)$
\end{tabular} & $70(34)$ & $72(13)$ & $\begin{array}{c}66 \\
(247)\end{array}$ & $71(9)$ & $\begin{array}{c}66 \\
(300)\end{array}$ & $\begin{array}{l}82 \\
(4)\end{array}$ & $80(3)$ & $\begin{array}{l}87 \\
(3)\end{array}$ & $85(1)$ & $75(613)$ \\
\hline Max & 89 & 80 & 88 & 73 & 88 & 88 & 83 & 89 & 85 & 87 \\
\hline
\end{tabular}

TABLE 4. 3 LISTS MEAN, MEAN MAX, AND MAXIMUM CW, SEX, AND SAMPLE SIZE (N) FROM SOUTH TO NORTH. 


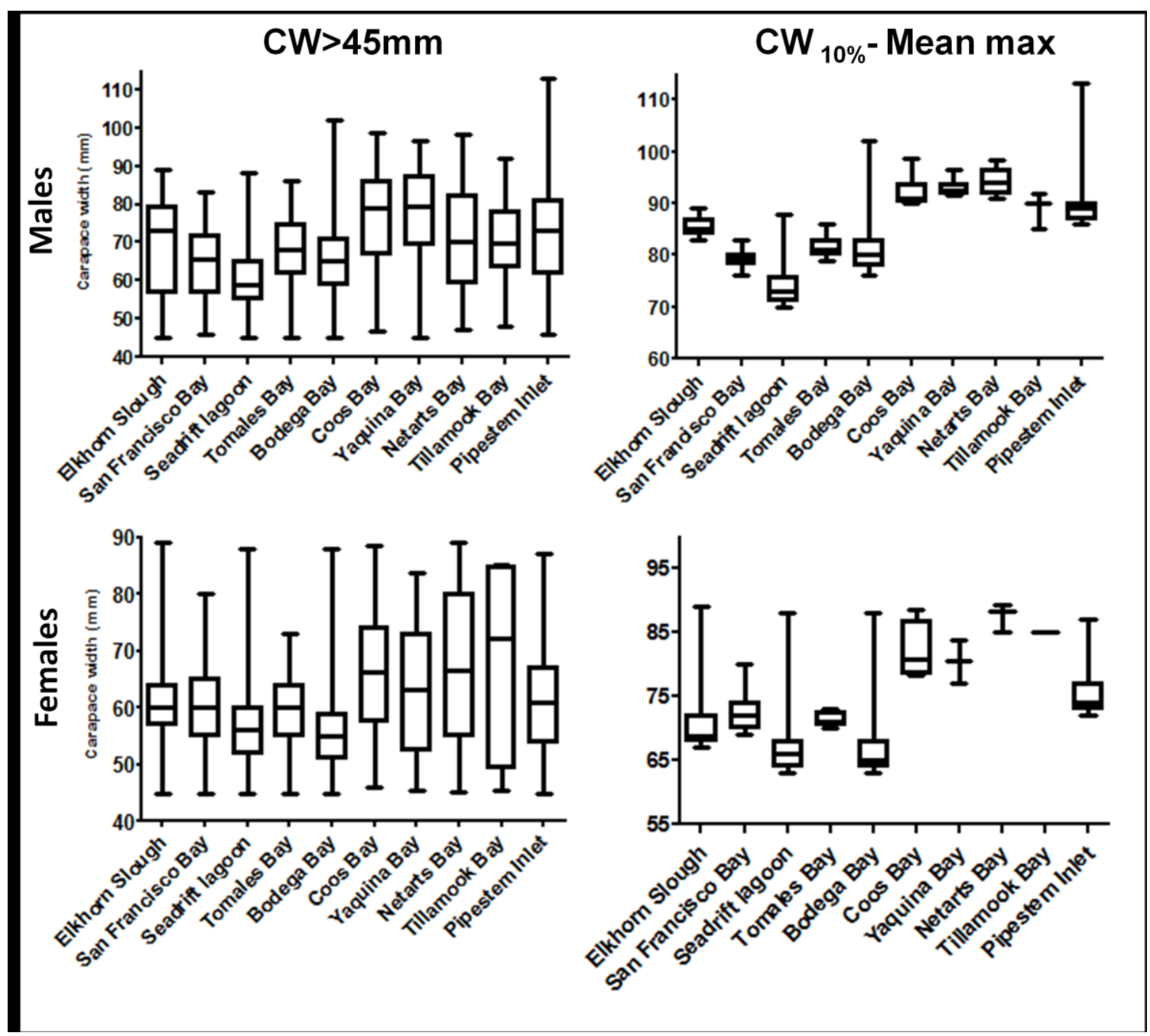

FIGURE 4. 2 BOX PLOT FOR EACH SAMPLE SITE MARKING SAMPLE MINIMUM, MAXIMUM AND QUARTILES OF CW (MM). PLOTS SHOW THE CW OF CRABS >45MM AND THE MEAN MAXIMUM VALUES (RIGHT) OF MALES (TOP) AND FEMALES (BOTTOM).

All three male size measures and mean and mean-maximum carapace width of females were significantly and positively correlated with latitude, clearly identifying latitudinal variation in body size across this invasive metapopulation (Fig. 4.4A, Table 4.4). Interestingly, latitude was not a good indicator of maximum size of females (Fig. 4.4B, Table 4.4; Max CW, Spearman $r=-0.006, p>0.99$ ). The most northern sample site, Pipestem Inlet, BC, recorded the largest male at $113 \mathrm{~mm}$. Seadrift Lagoon recorded the lowest mean and mean maximum values 
for males and both Seadrift Lagoon and Bodega Bay, California, registered the smallest mean and mean maximum CW measurements for females. There was a smaller degree of $\mathrm{CW}$ variation among the females, with 6 out of the 10 sites having females that were larger than $85 \mathrm{~mm}$.

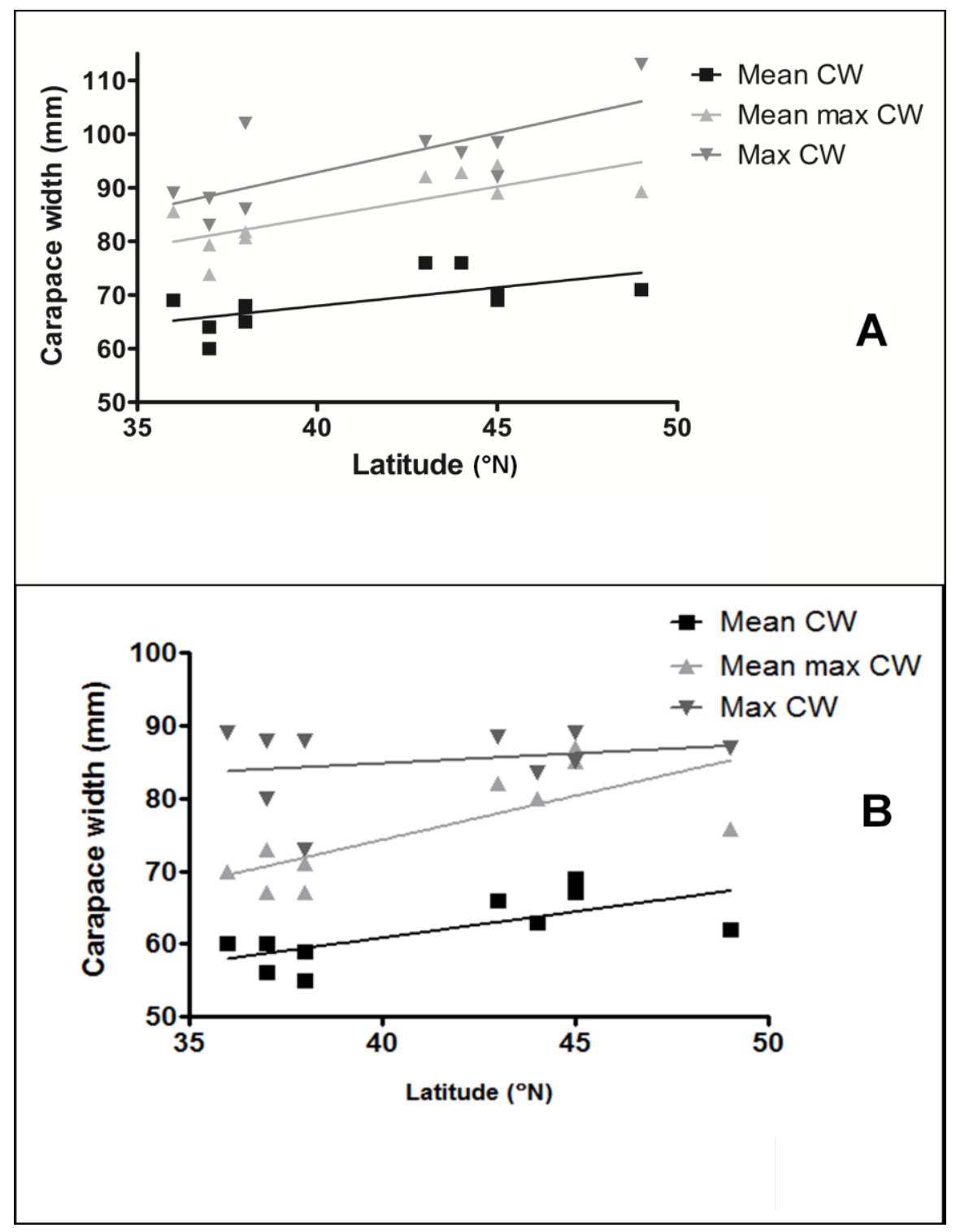

FIGURE 4.3 SCATTERPLOT (WITH LEAST-SQUARES REGRESSION LINE SHOWN TO HIGHLIGHT THE TREND) USING MEAN, MEAN MAX, AND MAXIMUM CW (MM) VALUES FROM EACH SAMPLE SITE AND LATITUDE $\left({ }^{\circ} \mathrm{N}\right)$ OF SAMPLE SITE FOR (A) MALES AND (B) FEMALES. 


\begin{tabular}{|c|c|c|c|}
\hline \multicolumn{4}{|c|}{ Correlation regression for CW vs latitude } \\
\hline Males & Mean CW & Mean max CW & Max CW \\
\hline Number of XY Pairs & 10 & 10 & 10 \\
\hline Pearson r & 0.62 & 0.77 & 0.74 \\
\hline 95\% confidence interval & -0.014 to 0.90 & 0.26 to 0.94 & 0.21 to 0.94 \\
\hline P value (two-tailed) & 0.0553 & 0.0097 & 0.0136 \\
\hline R & 0.62 & 0.76 & 0.74 \\
\hline Females & & & \\
\hline Number of XY Pairs & 10 & 10 & 10 \\
\hline Spearman r & 0.67 & 0.74 & -0.0061 \\
\hline P value (two-tailed) & 0.0390 & 0.0202 & 1.0000 \\
\hline
\end{tabular}

TABLE 4. 4 CORRELATION REGRESSION FOR MEAN, MEAN MAX, AND MAXIMUM CW (MM) AND LATITUDE, LISTING THE R VALUE, AND 95\% CONFIDENCE INTERVAL.

\section{CW and temperature trends}

There was a significant relationship between sample site mean temperature and $\mathrm{CW}$ for both males and females (Fig. 4.5, Table 4.5): as temperature decreased, mean and mean-maximum CW increased. Maximum $\mathrm{CW}$ was also significantly correlated with sample site temperature for males but not for females (Fig. 4.5, Table 4.5). Furthermore, the coldest mean temperature, $10.58^{\circ} \mathrm{C}$ corresponded to the largest male crab found, $113 \mathrm{~mm}$ in Pipestem Inlet; the smallest maximum CW value for males was recorded in San Francisco Bay, at $83 \mathrm{~mm}$, the warmest mean temperature of all sites at $15.56^{\circ} \mathrm{C}$ (Tables 4.1$)$. The 
correlation coefficients between temperature and carapace width were higher than those between latitude and carapace width, suggesting temperature, not latitude, is the driver of these patterns. Moreover, the strength of the relationship between $\mathrm{CW}$ and the corresponding mean SST in the native range, $\mathrm{R}=0.77$, was strikingly similar to the relationship in the invasive range, $R=0.77$.

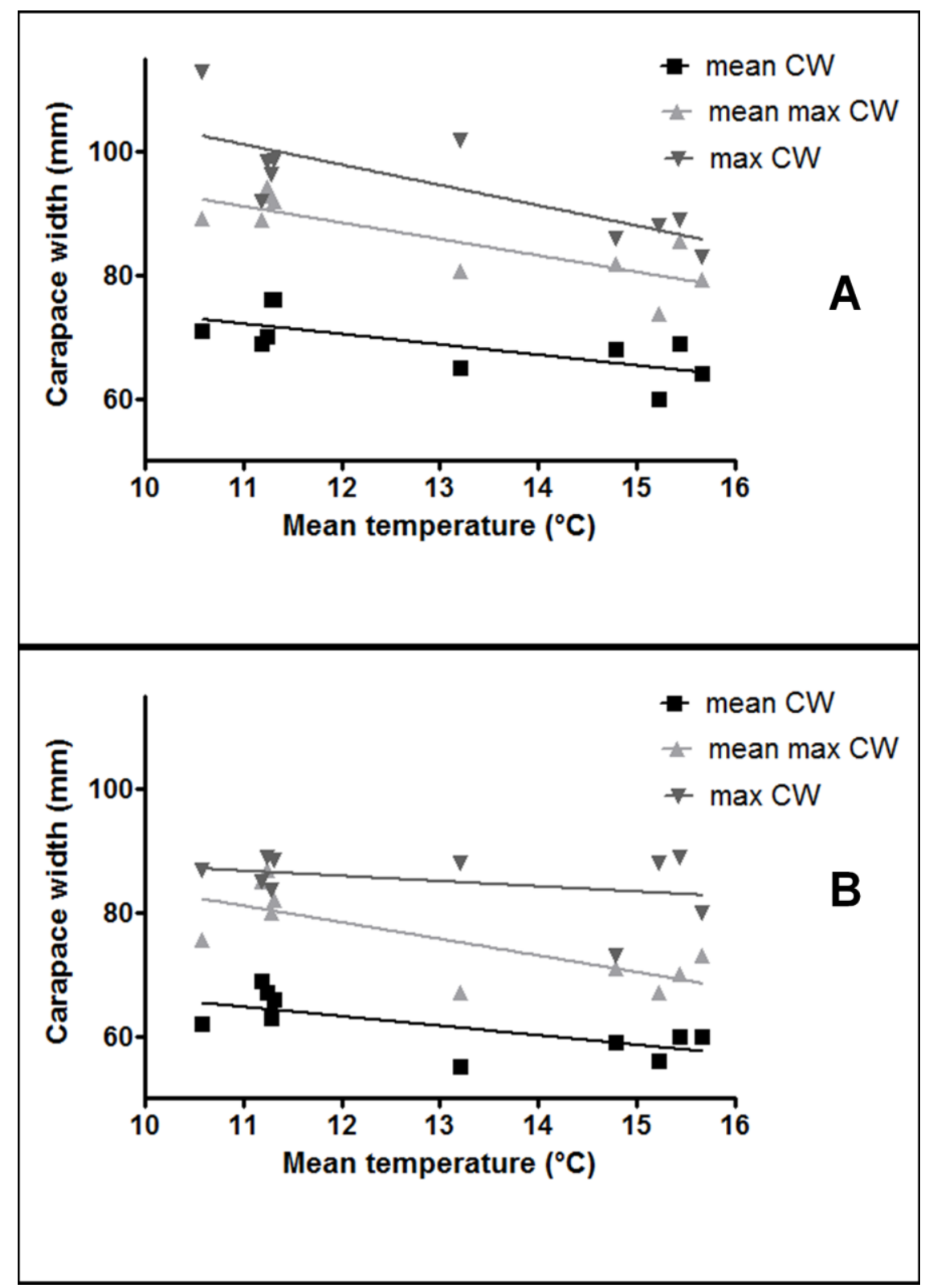


FIGURE 4.4 SCATTERPLOT (WITH LEAST-SQUARES REGRESSION LINE SHOWN TO HIGHLIGHT THE TREND) USING MEAN, MEAN MAX, AND MAXIMUM CW (MM) VALUES FROM EACH SAMPLE SITE AND TEMPERATURE $\left({ }^{\circ} \mathrm{C}\right)$ OF SAMPLE SITE FOR (A) MALES AND (B) FEMALES.

\begin{tabular}{|c|c|c|c|}
\hline \multicolumn{4}{|c|}{ Correlation regression for CW vs temperature } \\
\hline Males & Mean CW & Mean max CW & Max CW \\
\hline Number of XY Pairs & 10 & 10 & 10 \\
\hline Pearson $r$ & -0.71 & -0.82 & -0.77 \\
\hline 95\% confidence interval & -0.92 to -0.14 & -0.96 to -0.40 & -0.94 to -0.28 \\
\hline P value (two-tailed) & 0.0227 & 0.0034 & 0.0089 \\
\hline R & 0.7 & 0.82 & 0.77 \\
\hline Females & & & \\
\hline Number of XY Pairs & 10 & 10 & 10 \\
\hline Spearman $r$ & 0.67 & 0.74 & -0.0061 \\
\hline P value (two-tailed) & 0.0390 & 0.0202 & 1.0000 \\
\hline
\end{tabular}

TABLE 4.5 CORRELATION REGRESSION FOR MEAN, MEAN MAX, AND MAXIMUM CW (MM) AND TEMPERATURE, LISTING THE R VALUE, AND 95\% CONFIDENCE INTERVAL. 


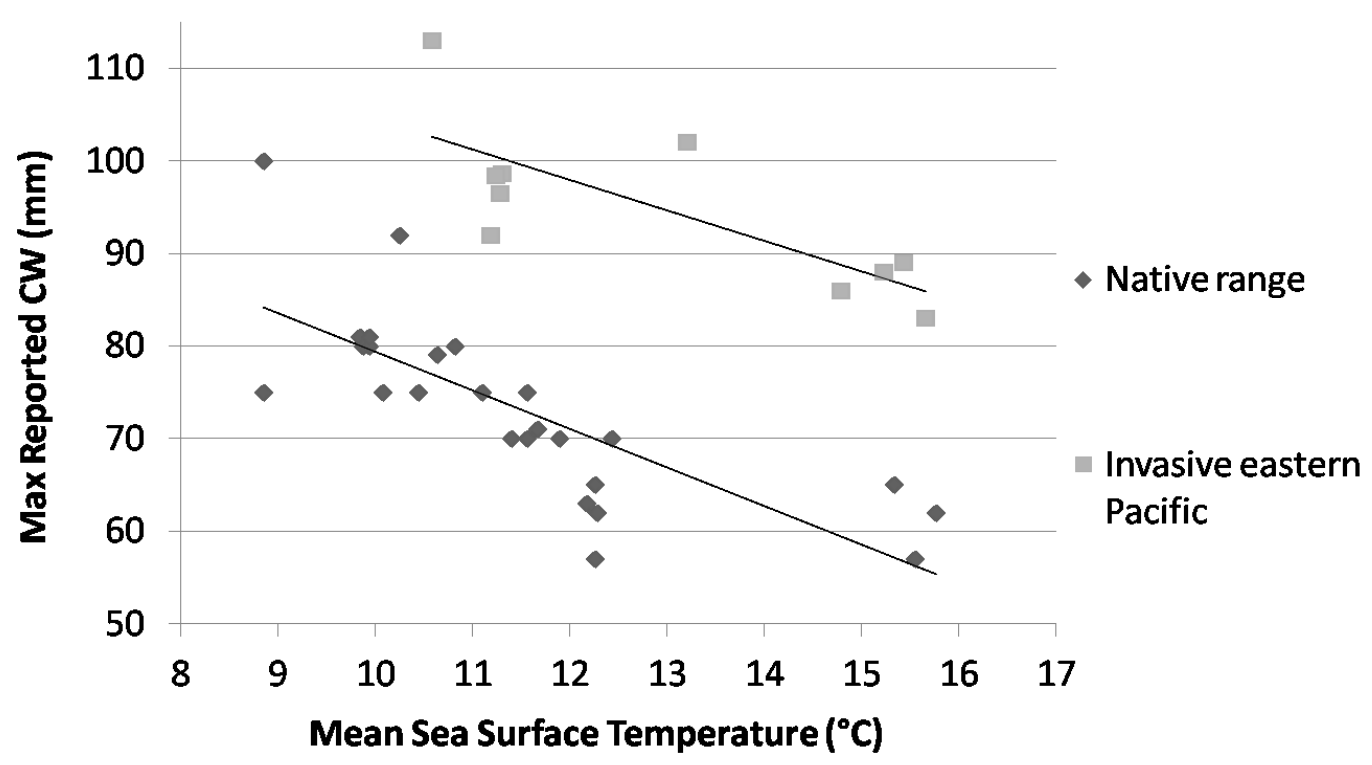

FIGURE 4.5 LINEAR REGRESSION OF MAXIMUM REPORTED MALE CW (MM) VERSUS TEMPERATURE $\left({ }^{\circ} \mathrm{C}\right)$ FROM THE NATIVE RANGE $(\mathrm{R}=0.77 ; \mathrm{Y}=-4.1824 \mathrm{X}+121.23$; LISTED IN TABLE 4.2) AND THE INVASIVE RANGE $\left(R^{=} 0.77 ; Y=-3.2984 X+137.51\right.$; LISTED IN TABLE $4.1,4.3)$.

Sample site latitude of Pacific Northwest sites explained most of the variation in mean annual temperature (Fig. 4.6; $R=0.94, p<0.0001$ ). There was a $5^{\circ} \mathrm{C}$ difference in mean temperature across the recipient range from north to south (Table 4.1). The lowest mean temperature value was $10.58^{\circ} \mathrm{C}$ from $\mathrm{BC}$, and the highest mean temperature value was $15.66^{\circ} \mathrm{C}$ from San Francisco Bay. 


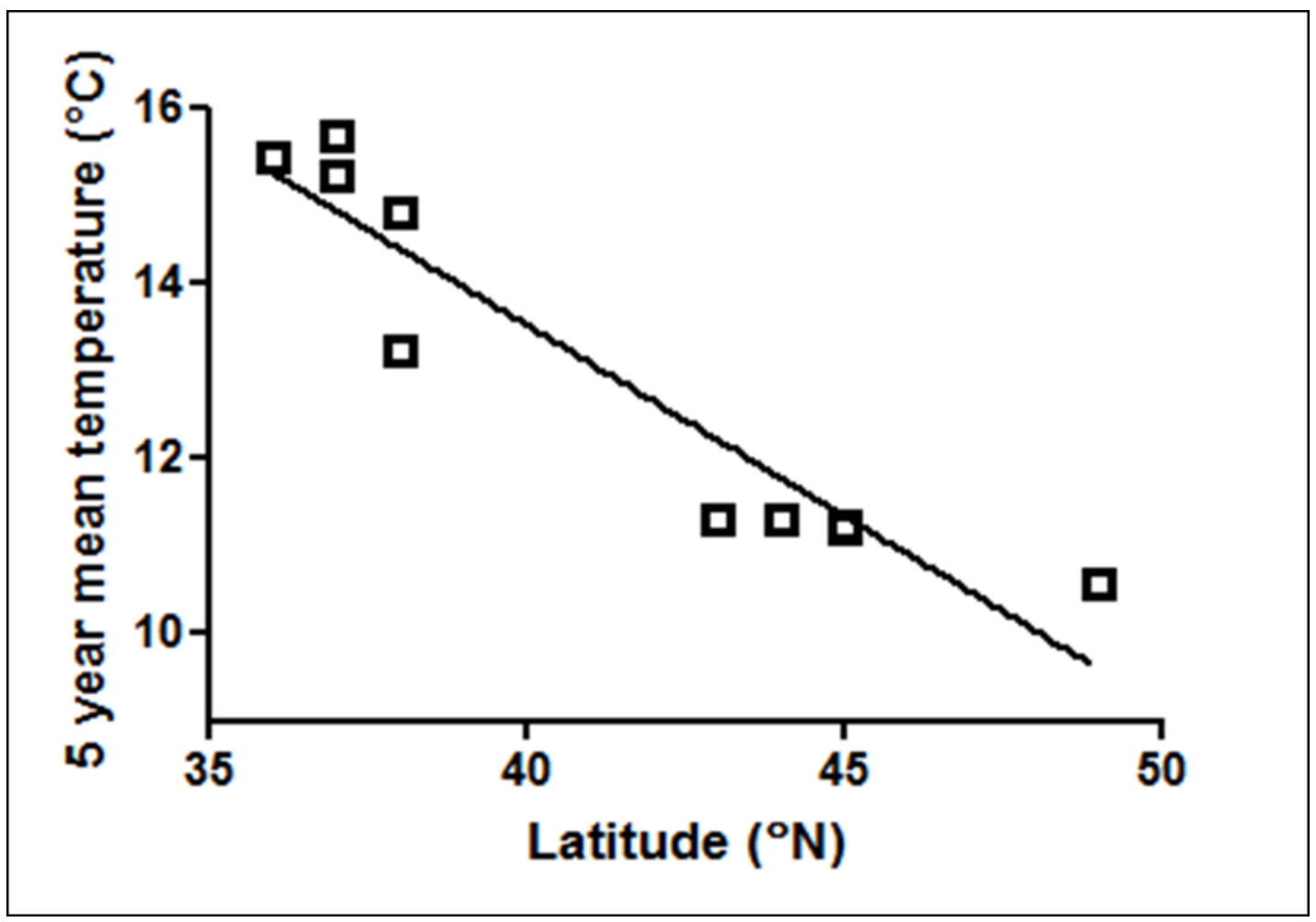

FIGURE 4. 6 LINEAR REGRESSION OF MEAN TEMPERATURE $\left({ }^{\circ} \mathrm{C}\right)$ OF EACH SAMPLE SITE VERSUS LATITUDE $\left({ }^{\circ} \mathrm{N}\right)(\mathrm{R}=0.94 ; \mathrm{Y}=-2.0342 \mathrm{X}+67.631)$.

\section{Discussion}

This study demonstrates a biogeographic cline in CW of Carcinus maenas across the west coast of North America, where this species recently invaded. For both males and females, an increase in body size was positively correlated with sample site latitude and negatively correlated with environmental temperature (Fig 4.3 AB, 4.4 AB). The mean of the maximum $10 \%$ of the adult carapace width values was more strongly correlated with latitude and temperature for both males and females than the mean or maximum size values were. Female size was constricted to $<90 \mathrm{~mm}$, and the maximum size females achieved remained consistent across sample sites from north to south (Fig. 4.2). 
Below we examine why temperature is the variable most likely responsible for the site-specific variation of adult size in Carcinus maenas along the west coast of North America. We discuss possible physiological mechanisms that may be responsible for this variation in phenotype, and how other abiotic constraints have the potential to influence body size. Finally, we address how variation in $\mathrm{CW}$ may potentially impact invasion success.

Genetic versus developmental response to temperature

Temperature has a profound effect on physiological properties at all levels of biological organization from organismal fitness to cellular homeostasis (Feder and Hofmann 1999, Somero 2002, 2005). Temperature has been shown to affect the trait of body size in two ways. First, environmental temperature may act as a selecting agent, producing evolutionary changes (via genetic mutation) in the genes controlling growth rate and adult size (Partridge et al. 1994, Johnston and Bennett 1996). Second, variations in rearing temperature during development can modify the expression of genes governing growth, resulting in a phenotypically plastic response (Johnston and Bennett 1996).

Rapid evolution of this invasive population mediated by thermal constraints may have resulted in changes to the underlying genome, and is one possible mechanism driving this biogeographic variation in size, albeit unlikely. Temperature has previously been found to be a transformative agent for natural selection, creating a genetic basis for observed variation in body size (Somero 2002, 2005). For instance, repeated breeding of Drosophila at lower rearing 
temperatures over generations produced a larger body size via alterations to the genome than conspecifics bred at warmer temperatures (Partridge 1994). Since the original introduction in 1989 (Cohen et al. 1995), this metapopulation has completed at most 22 generations, likely insufficient to produce any adaptive genetic changes that would be responsible for the observed size difference. Furthermore, this metapopulation is thought to have been established by no more than 50 individuals (Tepolt et al. 2009), and represents the lowest degree of genetic diversity of all native and invasive ranges (Darling et al. 2008). Therefore it is also improbable that genetic diversity is culpable for the spectrum of $\mathrm{CW}$ present across this range.

Phenotypic plasticity in the trait of body size, known as the temperaturesize rule in ectotherms, is a more likely driver of the pattern. The temperature size-rule has been examined extensively in Drosophila spp. (David et al. 1997, Morin and Pétavy 1999, Gibert and De Jong 2001, Bochdanovits and de Jong 2003), providing a general model for our investigations. Drosophila larvae reared at low temperatures had prolonged instar stages (increased development time), and a greater mass at each larval stage, which then resulted in significantly larger adults compared to larvae reared at warmer temperatures (Atkinson and Sibly 1997). Support for the temperature-size rule, as outlined using the Drosophila model, would require C. maenas larvae to grow larger after being exposed to temperatures that are cooler than ones in the source population site, California (CA). Exposure to the colder water could occur from planktonic larvae 
either exiting the maternal site and being carried into seasonally cooler waters (Oregon/British Columbia, $\mathrm{OR} / \mathrm{BC}$ ) or originating from an area that is cooler than the original site of introduction (CA) and developing there or even further north.

Larval development rates of C. maenas are in fact governed by environmental temperature, with cooler temperatures substantially extending the overall larval development period for both native and invaded ranges (Klein Breteler 1975, Mohamedeen and Hartnoll 1990, de Rivera et al. 2007). For this invasive metapopulation, range expansion has been predominately poleward. Larval exposure to cold temperatures could trigger an alternative gene expression pattern resulting in an overall slowing of metabolic mechanisms and/or an alteration in the regulation of growth hormones, facilitating a larger body size (Nijhout et al. 2006).

Evidence for the temperature size rule for ectotherms is also apparent in the native populations of $C$. maenas (Fig.4.5). Two laboratory studies on $C$. maenas from the native range provide powerful experimental evidence supporting the temperature-size rule as a potential driver of size in this species. Mohamedeen and Hartnoll (1990) found that males and females reared at $15^{\circ} \mathrm{C}$ attained larger $\mathrm{CW}$ measurements than those reared at $20^{\circ} \mathrm{C}$ at every juvenile instar stage (1-14). Similarly, larvae cultured at $15^{\circ} \mathrm{C}$ grew significantly larger than ones at $20^{\circ} \mathrm{C}$, attaining larger carapace widths and greater mass, for three of six examined juvenile development stages (Klein Breteler 1975). Furthermore, analogous results were found for Carcinus maenas from the east coast of North 
America: Juvenile males grew more across molts when cultured at $10^{\circ} \mathrm{C}$ than at $16^{\circ} \mathrm{C}$ (Baldridge and Smith 2008). These findings suggest that this sizetemperature relationship is present in both native and invasive ranges, regardless of the breadth of genetic diversity of the sampled populations. Silva et al. (2010) noted C. maenas in the native range (UK) varied in size and claw morphology along an environmental gradient stretching $432 \mathrm{~km}$ despite lack of genetic differentiation (Silva et al. 2010). Like Carcinus, larvae of the Pacific brachyuran Metacarcinus magister (syn Cancer magister) reared at different temperatures exhibited a significantly larger larval morphology and extended larval development periods when reared at $5^{\circ} \mathrm{C}$ as opposed to $15^{\circ} \mathrm{C}$ (Shirley et al. 1987). This pattern has also been found in other brachyuran crabs, with the larger individuals occupying areas of lower temperatures and higher latitudes (Hines 1989).

The largest individual male (104 mm CW notch-to-notch, equivalent to 113 mm CW spine-to-spine) was collected from Pipestem Inlet, British Columbia. To our knowledge, this is the largest male green crab ever recorded in either the native or invasive ranges. Previously, the largest recorded male was $100 \mathrm{~mm}$ CW from spine to spine, collected from Sweden (Eriksson and Edlund 1977, Behrens-Yamada et al. 2005). This large size in the northeastern Pacific is consistent with predictions made soon after the initial invasion of this range (Grosholz and Ruiz 1996). The eastern Pacific population of Carcinus maenas 
recorded a higher percent increase of $\mathrm{CW}$ at molt than populations on both sides of the north Atlantic (Behrens-Yamada et al. 2005).

The large body size of the west coast population may be at least in part a result of being released from its parasitic castrator found in the native range (Torchin et al. 2001). It is apparent that the west coast metapopulation is generally larger across sample site temperatures in the invasive range when compared to the native range (Fig. 4.5), and this generally supports the release from enemy hypothesis. Alternatively, the reason the large size (>100 $\mathrm{mm} \mathrm{CW})$ is absent in the northern native range may be that the additive genetic component of the other haplotypes are diluting the expression of this trait. In contrast, the genotypic restriction of the northeast Pacific metapopulation (Darling et al. 2008, Tepolt et al. 2009) may allow for a greater plastic response. Our data suggest that both metapopulations experience this temperature size relationship and that the northeast Pacific population has potentially experienced a release from enemies, allowing larger size.

Unlike males, females across this metapopulation tended to be less affected by temperature, with 6 out of 10 populations having females that were at least $85 \mathrm{~mm}$ in CW (Fig. 4.2). Perhaps the ecological constraints experienced by males were, to some degree, different for females, and/or, there was a greater selection force imposed on females for larger body size.

It is our assertion that environmental temperature plays a substantial role in determining final adult size in Carcinus maenas; however, it should be noted 
that many ecological factors influence this trait, and may also affect the variation in carapace width. For example, it has been shown that growth rate and body size are density dependent in Carcinus maenas, even when food is provided in excess, with the faster rate of growth, and larger body size achieved in lower density population (Moksnes 2004). Indeed, Sea Drift Lagoon, CA, which currently has the highest density of $C$. maenas on the west coast (de Rivera, Grosholz, \& Ruiz unpublished data), harbored the lowest mean and mean maximum values for males, and the second lowest mean for females (Table 4.3). This set of ecological factors anecdotally provide an additional mechanism that may be working synergistically with temperature to further drive the reduction in body size in this population. Increased variation in salinity reduces growth and size in Carcinus maenas larvae (Klein Breteler 1975); however, adults tend to be less sensitive to salinity variations, with individuals surviving exposure to $5 \mathrm{ppt}$ indefinitely (Broekhuysen 1936, McGaw and Naylor 1992). Preferred salinities range between 17-40 ppt for juveniles and adults (Ameyaw-Akumfi and Naylor 1987).

Implications of increased body size to invasion capacity

In general, larger adult body size is associated with higher fitness for males and females, including increases in reproductive success, fecundity, longevity, and survival (Blueweiss 1978, Partridge and Fowler 1993, Roff 2002, Speakman 2005). In male stone crabs, Hapalogaster dentata, females that mated with larger males had a significantly higher rate of fertilization success 
when compared to smaller male conspecifics (Sato 2007). For female brachyuran crabs in particular (the infraorder to which Carcinus spp. belongs), body size has been shown to directly influence the extent of fecundity and reproductive output (Hines 1982, Hines 1988). Larger females produced more eggs per brood than smaller crabs (Hines 1982, Hines 1988). In many ectotherms, longevity decreased with increasing temperature (Norry and Loeschcke 2002, Karlsson and Wiklund 2005), implicating a reduction in environmental temperature as the mechanism that can concomitantly produce increases in the traits of longevity and body size.

From an ecological perspective, larger size may be advantageous in resource competition (Bonner 1988), prey capture or predator escape (Benton 2002), resource utilization (Brown and Maurer 1986), and resistance to extreme environmental conditions (Peters 1983). It also confers a competitive advantage over smaller animals (Schoener 1969). Hence, temperature of invaded site may affect invasion success, with cooler temperatures within the tolerances of a species may produce greater invasion success.

Body size directly influences many biological traits, and this type of variation can have an effect spanning across many levels of biological organization from the individual to the ecosystem (Woodward et al. 2005). When discussing the variation in body size in the context of an invasive species, there is a potential for variation in this trait to affect invasion capacity, perhaps altering the scope of invasion success. For example, if larger crabs are more fecund, the 
increase in the number of larvae can directly increase establishment success and spread, potentially enhancing the likelihood of range expansion. Regarding longevity, an increase in this trait can extend the time period of reproductive output, conceivably further increasing overall fecundity and reducing the chance of extirpation of a population.

Interspecific interactions such as predation, competition, and resource utilization may shift as a result of an increase in body size of this invasive species. In the waters off British Columbia, the most common native crab that is found to cohabitate with Carcinus maenas is Metacarcinus gracilis, the slender rock crab (Graham Gillespie, unpublished data). This native brachyuran reaches a maximum size of roughly $90 \mathrm{~mm}$ (Kozloff 1983). Given the larger size achieved by Carcinus maenas in this region, it is possible that Carcinus maenas has reached a size-based refuge from predation by $M$. gracilis, and may challenge this native species in competition for food, habitat space, and resource utilization as well.

In summary, characterizing those traits that may facilitate invasion success is paramount to: 1) identifying which species, if introduced, would pose a particularly broad ecological threat to native marine communities; and 2) remaining vigilant in preventing their introduction into novel environments. Our data suggest that biogeographic variation in $\mathrm{CW}$ exists across this invasive metapopulation, and that temperature is one of the main driving forces behind this variation. Nevertheless, it is clear that multiple ecological factors are involved 
in the expression if this phenotype. Whether the product of adaptation by natural selection, or temperature-induced plasticity, characterizing the scope of phenotypic expression across a heterogeneous landscape can provide insight into those mechanisms that are involved in establishment success. 


\section{CHAPTER FIVE: PHYSIOLOGICAL CORRELATES OF SPECIES INVASION}

\section{Introduction}

One of the fundamental questions in invasion ecology is, "What makes an invading species successful?" (Elton 1958). Over 50 years of research addressing this question has shown that a variety of life history traits and other biological characteristics promote invasion success. For example, generalist predatory habits (Snyder and Evans 2006), dynamic population growth after an initial lag period (Sakai et al. 2001), superior competitive ability relative to native organisms (Callaway and Ridenour 2004) and eurytolerance are among the features that facilitate establishment of non-native species.

Despite a rich literature on the role of physiological processes shaping evolutionary trajectories and biogeographic distributions of native species (Somero 2002, Somero 2005), there has until recently been a dearth of studies that aim to evaluate the physiology of invasive species. Investigating the ecophysiology of invasive species is an emerging field that illuminates physiologic mechanisms that may facilitate invasion success. Several studies have characterized species-specific mechanisms such as the expression of heat shock proteins (Kelley et al. 2011) or have compared a specific physiologic component between an invader and its native congener, such as the lethal thermal limit, LT50 (Slabber et al. 2007). Few studies, however, have attempted to determine 
what physiological traits confer invasion success across taxa (Zerebecki and Sorte 2011). Narrative reviews of invasion physiology have provided anecdotal evidence of such mechanisms, but empirical support is lacking (Pyšek and Richardson 2007). The last several years have seen a marked increase in research investigating the physiology of invasion. Hence, we now have the opportunity to compare studies to identify physiological traits with the potential to foster invasion success across broad taxonomic groups.

For ectotherms, environmental eurytolerance is a key factor that underlies establishment success (Lee et al. 2003, Hänfling et al. 2011). Many biological processes at multiple levels of biological organization contribute to the establishment of environmental tolerances such as thermal tolerance, salinity tolerance, and hypoxia or anoxia tolerance. Organismal, cellular, and metabolic processes each play a part in setting the limits of physiological tolerance, and are differentially regulated depending on the abiotic constraint in question (Prosser 1991, Johnston and Bennett 2008). A history of research on the physiology of native species provides many measurements like LT50 (characterizing the upper thermotolerance of a species or population), which is known to be appropriate for comparing organismal thermal tolerance limits and can be used to compare invasive populations with each other or with their native congeners. Such measurements can highlight physiological differences that may potentially lead to a greater likelihood of invasion success. 
The goals of this review are severalfold. The first goal was to outline a general framework that can be utilized to test hypotheses regarding the potential physiological differences between native and invasive species. Secondly, this review can increase our general understanding of the ecology of invasive species and the mechanistic bases of their success. The review compares the physiological mechanisms and responses of native versus invasive ectotherms, and attempts to understand how a species' utilization of a physiologic trait promotes invasion success. In particular, it highlights physiological responses that help achieve cellular or organismal homeostasis and thereby can facilitate invasion success. While the physiological responses and mechanisms reviewed here are not exclusive to invasive species, they are commonly found among invasive species and are thus likely to help these organisms overcome potential abiotic resistance of recipient habitats. Both terrestrial and aquatic ectotherms are considered in this paper to illustrate that the physiologic mechanisms highlighted are utilized across diverse taxa and habitat types.

I examine four related hypotheses that are not mutually exclusive: 1) Broad geographic temperature tolerances (thermal width) confer a higher thermal threshold for invasive species compared to native species, 2) The upper thermal extreme experienced in nature is correlated with upper thermal tolerance threshold, 3) Protein chaperone expression, a cellular mechanism underlying thermal tolerance threshold, is greater in invasive organisms than in native ones, and 4) Acclimation to higher temperatures can promote a greater range of 
thermal tolerance for invasive species compared to native species. The rationale for each hypothesis is explained below.

Organisms that possess broad thermal tolerances have increased invasion success (Forcella and Wood 1984, Rejmánek 1996, Rejmanek 2000, McMahon 2002, Braby and Somero 2006, Zerebecki and Sorte 2011). Species experiencing broad thermal regimes in their native range may be equipped (preadapted) for survival in many potential recipient environments. Often, this broad tolerance is a product of chronic, oscillating (often daily) thermal perturbation, and frequently includes higher maximal temperatures compared to those experienced by species native to the recipient range (Forcella and Wood 1984, Carveth et al. 2006).

Invasive species often have lethal thermal thresholds that exceed what is physiologically necessary for the environment that they inhabit (Hofmann and Somero 1996a, Braby 2004, Tomanek and Zuzow 2010, Zerebecki and Sorte 2011). Augmentation of lethal thermal thresholds can provide an invasive organism with a physiological advantage over a native organism, by allowing invaders to maintain organismal homeostasis at temperatures that would be detrimental or lethal to native species.

Heat shock proteins (Hsp's), are molecular chaperones that facilitate refolding of denatured macromolecules (Lindquist 1986, Feder and Hofmann 1999, Fink 1999) and their induction in response to temperature constitutes a cellular mechanism that is directly involved in the maintenance of organismal 
thermal tolerance (Sanders et al. 1991, Sørensen et al. 2003, Sorte and Hofmann 2005). Induction of Hsp's is hypothesized to be greater in invasive organisms relative to ones native to the recipient range, and further that invaders have a higher Hsp induction temperature than native species (Hofmann and Somero 1996a, Braby 2004).

The capacity of organisms to alter their scope of thermal tolerance has been thoroughly explored in the scientific literature (Dietz and Somero 1992, Buckley et al. 2001, Braby and Somero 2006, Wada and Matsukura 2007). It is hypothesized that invaders use acclimation to increase their capacity to broaden the range of thermotolerance, which may potentially constitute another mechanism that provides invaders a physiological advantage over native species (Chown et al. 2007, Slabber et al. 2007, Hofmann and Todgham 2010).

\section{Methodological approaches to comparing physiological responses between native and invasive organisms}

I conducted a literature search of peer-reviewed articles to evaluate the above four hypotheses based on an examination of work that included physiological responses of invasive and native organisms. The four hypotheses have been investigated previously, although on a much smaller scale than what is presented here.

\section{Protocol for peer-reviewed literature search}

I searched Google Scholar for articles that fit the criteria necessary to test each hypothesis. The search terms I used are listed as follows: invasive species, 
non-native species, LT50, CTmax, acclimation, upper thermal tolerance, lethal thermal threshold, lethal thermal limit, thermotolerance, acclimation response ratio, Heat shock protein, Hsp, protein chaperone, heat stress, and thermal stress. For inclusion in this review, only articles with the following were used: laboratory measured LT50/CTmax values, species name, general taxonomy, high and low geographic thermal limits measured in situ, and origin- native or invasive. This search yielded $\sim 850$ results of which 75 were useful for each analysis (Tables 5.1-3).

Range width associated with broad physiological tolerance

To test the hypothesis that temperature tolerance increases with geographic temperature range, I compared the geographic thermal range (the upper and lower temperature range experienced by the organism in either the native or invasive range) and the upper thermal tolerance limit (LT50) of native and invasive populations of several ectotherms. I then investigated the relationship between thermal range experienced in situ and the laboratoryderived upper thermal tolerance limit- LT50. This approach was modeled after Zerebecki and Sorte (2011). Table 5.1 lists the species, general taxonomy, upper and lower thermal range $\left({ }^{\circ} \mathrm{C}\right)$, LT50 $\left({ }^{\circ} \mathrm{C}\right)$, origin (native or invasive), acclimation temperature $\left({ }^{\circ} \mathrm{C}\right)$, rate of thermal ramping, life stage, and citation(s) for the above data. A Grubb's test for outliers was performed, and no outliers were identified $(p>0.05)$. 
When multiple temperature ramping rates were used in a study or in the literature, I included here the highest LT50 value that was recorded. For example, Dreissena polymorpha and Dreissena bugensis, the zebra and quagga mussel, respectively, were tested at several different ramping rates, but the rate elicited the highest LT50 was used (Mills et al. 1996).

\begin{tabular}{|c|c|c|c|c|c|c|c|c|c|}
\hline 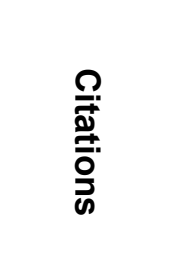 & 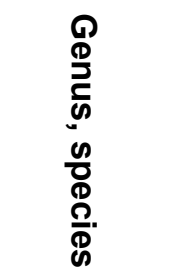 & 음. & $\begin{array}{l}-1 \\
\dot{0} \\
0 \\
0 \\
0\end{array}$ & 옹 ? & 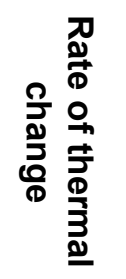 & $\frac{3}{3}$ & $\frac{3}{\stackrel{3}{x}}$ & 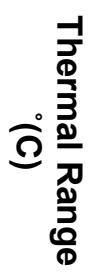 & 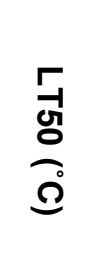 \\
\hline $\begin{array}{c}\text { (Zerebecki } \\
\text { and Sorte } \\
2011 \text { ) }\end{array}$ & $\begin{array}{l}\text { Bugula } \\
\text { neritina }\end{array}$ & Invasive & Bryozoan & 12 & $4 \mathrm{C}^{\circ} / \mathrm{hr}$ & 2.2 & 30.6 & 28.4 & 24.4 \\
\hline $\begin{array}{c}\text { (Zerebecki } \\
\text { and Sorte } \\
2011 \text { ) }\end{array}$ & $\begin{array}{c}\text { Watersipo } \\
\text { ra } \\
\text { subtorqua } \\
\text { ta }\end{array}$ & Invasive & Bryozoan & 12 & $4 \mathrm{C}^{\circ} / \mathrm{hr}$ & 6.7 & 30.6 & 23.9 & 24.7 \\
\hline $\begin{array}{c}\text { (Zerebecki } \\
\text { and Sorte } \\
2011 \text { ) }\end{array}$ & $\begin{array}{l}\text { Botrylloid } \\
\text { es } \\
\text { violaceus }\end{array}$ & Invasive & Tunicate & 12 & $4 \mathrm{C}^{\circ} / \mathrm{hr}$ & $\begin{array}{c}- \\
0.6\end{array}$ & 29.3 & 29.9 & 25.3 \\
\hline $\begin{array}{c}\text { (Zerebecki } \\
\text { and Sorte } \\
\text { 2011) }\end{array}$ & $\begin{array}{c}\text { Didemnu } \\
m \\
\text { vexillum }\end{array}$ & Invasive & Tunicate & 12 & $4 \mathrm{C}^{\circ} / \mathrm{hr}$ & 2.2 & 30.6 & 28.4 & 26.1 \\
\hline $\begin{array}{c}\text { (Zerebecki } \\
\text { and Sorte } \\
2011 \text { ) }\end{array}$ & $\begin{array}{c}\text { Diplosom } \\
\text { a } \\
\text { listerianu } \\
m \\
\end{array}$ & Invasive & Tunicate & 12 & $4 \mathrm{C}^{\circ} / \mathrm{hr}$ & $\overline{0}^{-}$ & 30 & 30.6 & 27.9 \\
\hline $\begin{array}{c}\text { (Zerebecki } \\
\text { and Sorte } \\
\text { 2011) }\end{array}$ & $\begin{array}{l}\text { Botryllus } \\
\text { schlosseri }\end{array}$ & Invasive & Tunicate & 12 & $4 \mathrm{C}^{\circ} / \mathrm{hr}$ & 2.8 & 30.6 & 27.8 & 28.3 \\
\hline $\begin{array}{c}\text { (Braby and } \\
\text { Somero } \\
2006 b)\end{array}$ & $\begin{array}{c}\text { Mytilus } \\
\text { gallaprovi } \\
\text { ncialis }\end{array}$ & Invasive & Bivalve & 14 & $6 \mathrm{C}^{\circ} / \mathrm{hr}$ & 2 & 36 & 34 & 28.7 \\
\hline $\begin{array}{l}\text { (Fowler et } \\
\text { al. 2011) }\end{array}$ & $\begin{array}{l}\text { Charybdis } \\
\text { japonica }\end{array}$ & Invasive & Decapod & & & 4 & 34 & 30 & 34.1 \\
\hline
\end{tabular}




\begin{tabular}{|c|c|c|c|c|c|c|c|c|c|}
\hline $\begin{array}{l}\text { (Cuculescu } \\
\text { et al. 1998, } \\
\text { Kelley et al. } \\
\text { 2011) }\end{array}$ & $\begin{array}{l}\text { Carcinus } \\
\text { maenas }\end{array}$ & Invasive & Decapod & 23 & $4 \mathrm{C}^{\circ} / \mathrm{hr}$ & -1 & 35 & 36 & 36.1 \\
\hline $\begin{array}{c}\text { (Yingying } \\
2008 \text { ) }\end{array}$ & $\begin{array}{c}\text { Pomacea } \\
\text { canalicula } \\
\text { ta }\end{array}$ & Invasive & $\begin{array}{c}\text { Gastropo } \\
\text { da }\end{array}$ & & & 6 & 42 & 36 & 36 \\
\hline $\begin{array}{l}\text { (Nalepa and } \\
\text { Schloesser } \\
\text { 1993, Mills } \\
\text { et al. 1996) }\end{array}$ & $\begin{array}{c}\text { Dreissena } \\
\text { polymorp } \\
\text { ha }\end{array}$ & Invasive & Bivalve & 20 & $4 \mathrm{C}^{\circ} / \mathrm{hr}$ & 0 & 30 & 30 & 37.08 \\
\hline $\begin{array}{l}\text { (Mills et al. } \\
1996, \\
\text { Claxton and } \\
\text { Mackie } \\
\text { 1998) }\end{array}$ & $\begin{array}{c}\text { Dreissena } \\
\text { bugensis }\end{array}$ & Invasive & Bivalve & 20 & $4 \mathrm{C}^{\circ} / \mathrm{hr}$ & 4 & 32 & 28 & 34.63 \\
\hline $\begin{array}{c}\text { Schevchenk } \\
\text { o (Ashton } \\
2004, \\
\text { Ashton et } \\
\text { al. 2007) }\end{array}$ & $\begin{array}{c}\text { Caprella } \\
\text { mutica }\end{array}$ & Invasive & $\begin{array}{l}\text { Amphipo } \\
\text { da }\end{array}$ & 14 & & -1 & 25 & 26 & 28.3 \\
\hline $\begin{array}{l}\text { (Ramakrish } \\
\text { nan 2007, } \\
\text { Rawlings et } \\
\text { al. 2007, } \\
\text { Byers et al. } \\
2013 \text { ) }\end{array}$ & $\begin{array}{c}\text { Pomacea } \\
\text { canalicula } \\
\text { ta }\end{array}$ & Invasive & $\begin{array}{l}\text { Gastropo } \\
\text { da }\end{array}$ & 30 & & 4 & 36 & 32 & 36 \\
\hline $\begin{array}{c}\text { Zaranko } \\
\text { (Quinn et al. } \\
1994, \\
\text { Zaranko et } \\
\text { al. 1997, } \\
\text { Cox and } \\
\text { Rutherford } \\
\text { 2000) }\end{array}$ & $\begin{array}{c}\text { Potamopy } \\
\text { rgus } \\
\text { antipodar } \\
\text { um }\end{array}$ & Invasive & $\begin{array}{c}\text { Gastropo } \\
\text { da }\end{array}$ & & & 0 & 34 & 34 & 32 \\
\hline $\begin{array}{c}\text { Hao, 2012; } \\
\text { Muniz, } \\
\text { 2001; } \\
\text { Wang, 2011 } \\
\end{array}$ & $\begin{array}{c}\text { Bemisia } \\
\text { tabaci }\end{array}$ & Invasive & $\begin{array}{c}\text { Hemipter } \\
\text { a }\end{array}$ & & & -8 & 43 & 51 & 43.8 \\
\hline $\begin{array}{l}\frac{\text { http://www.fi }}{\text { sheriescons }} \\
\text { ervationfou } \\
\text { ndation.org/ } \\
\text { arcel/admin/ } \\
\text { uploads/FP } \\
\text { LP112.pdf } \\
\end{array}$ & $\begin{array}{l}\text { Pteroisvoli } \\
\text { tans }\end{array}$ & Invasive & Teleost & & $\begin{array}{c}12^{\circ} \mathrm{C} / \\
\mathrm{hr}\end{array}$ & 10 & 35 & 25 & 36.2 \\
\hline $\begin{array}{c}\text { (Zerebecki } \\
\text { and Sorte } \\
2011 \text { ) }\end{array}$ & $\begin{array}{c}\text { Distaplia } \\
\text { occidental } \\
\text { is }\end{array}$ & Native & Tunicate & 12 & $4 \mathrm{C}^{\circ} / \mathrm{hr}$ & $\overline{0.6}$ & 20 & 20.6 & 21.9 \\
\hline
\end{tabular}




\begin{tabular}{|c|c|c|c|c|c|c|c|c|c|}
\hline $\begin{array}{l}\text { (Zerebecki } \\
\text { and Sorte } \\
2011 \text { ) }\end{array}$ & $\begin{array}{l}\text { Ascidia } \\
\text { ceratodes }\end{array}$ & Native & Tunicate & 12 & $4 \mathrm{C}^{\circ} / \mathrm{hr}$ & 6.3 & 28.6 & 22.3 & 24.3 \\
\hline $\begin{array}{c}\text { (Zerebecki } \\
\text { and Sorte } \\
\text { 2011) }\end{array}$ & $\begin{array}{l}\text { Bugula } \\
\text { neritina }\end{array}$ & Native & Bryozoan & 12 & $4 \mathrm{C}^{\circ} / \mathrm{hr}$ & 7.2 & 29.4 & 22.2 & 24.5 \\
\hline $\begin{array}{l}\text { DeWacher, } \\
\text { 1996; } \\
\text { Prentice, } \\
1979\end{array}$ & $\begin{array}{c}\text { Metacarci } \\
\text { nus } \\
\text { magister }\end{array}$ & Native & Decapod & & & 0 & 27 & 27 & 33.5 \\
\hline $\begin{array}{c}\text { (Dallas and } \\
\text { Rivers- } \\
\text { Moore } \\
\text { 2012) } \\
\end{array}$ & $\begin{array}{c}\text { Lymnaeid } \\
a e^{*}\end{array}$ & Native & $\begin{array}{c}\text { Gastropo } \\
\text { da }\end{array}$ & 17 & $\begin{array}{c}20^{\circ} \mathrm{Cl} \\
\mathrm{hr}\end{array}$ & 9.8 & 27 & 17.2 & 39.2 \\
\hline $\begin{array}{c}\text { (Dallas and } \\
\text { Rivers- } \\
\text { Moore } \\
\text { 2012) } \\
\end{array}$ & $\begin{array}{c}\text { Parameliti } \\
\text { dae* }^{*}\end{array}$ & Native & $\begin{array}{l}\text { Amphipo } \\
\text { da }\end{array}$ & 17 & $\begin{array}{c}20^{\circ} \mathrm{Cl} \\
\mathrm{hr}\end{array}$ & 9.4 & 21.3 & 11.9 & 29.7 \\
\hline $\begin{array}{c}\text { (Dallas and } \\
\text { Rivers- } \\
\text { Moore } \\
\text { 2012) } \\
\end{array}$ & $\begin{array}{c}\text { Palaemon } \\
\text { idae* }\end{array}$ & Native & $\begin{array}{c}\text { Decapod } \\
\text { a }\end{array}$ & 17 & $\begin{array}{c}20^{\circ} \mathrm{Cl} \\
\mathrm{hr}\end{array}$ & 9.8 & 27 & 17.2 & 35.2 \\
\hline $\begin{array}{l}\text { (Dallas and } \\
\text { Rivers- } \\
\text { Moore } \\
\text { 2012) }\end{array}$ & Elmidae* & Native & $\begin{array}{c}\text { Coleopte } \\
\text { ra }\end{array}$ & 17 & $\begin{array}{c}20^{\circ} \mathrm{C} / \\
\mathrm{hr}\end{array}$ & 6.9 & 24.1 & 17.2 & 39 \\
\hline $\begin{array}{c}\text { (Dallas and } \\
\text { Rivers- } \\
\text { Moore } \\
\text { 2012) } \\
\end{array}$ & $\begin{array}{c}\text { Athericida } \\
e^{*}\end{array}$ & Native & Diptera & 17 & $\begin{array}{c}20^{\circ} \mathrm{Cl} \\
\mathrm{hr}\end{array}$ & 6.9 & 24.1 & 17.2 & 38.8 \\
\hline $\begin{array}{c}\text { (Dallas and } \\
\text { Rivers- } \\
\text { Moore } \\
\text { 2012) }\end{array}$ & $\underset{*}{\text { Simuliidae }}$ & Native & Diptera & 17 & $\begin{array}{c}20^{\circ} \mathrm{Cl} \\
\mathrm{hr}\end{array}$ & 6.9 & 24.1 & 17.2 & 30.3 \\
\hline $\begin{array}{l}\text { (Dallas and } \\
\text { Rivers- } \\
\text { Moore } \\
\text { 2012) }\end{array}$ & Baetidae* & Native & $\begin{array}{c}\text { Ephemer } \\
\text { optera }\end{array}$ & 17 & $\begin{array}{c}20^{\circ} \mathrm{Cl} \\
\mathrm{hr}\end{array}$ & 6.9 & 24.1 & 17.2 & 34.6 \\
\hline $\begin{array}{c}\text { (Dallas and } \\
\text { Rivers- } \\
\text { Moore } \\
\text { 2012) } \\
\end{array}$ & $\begin{array}{c}\text { Heptageni } \\
\text { idae* }^{*}\end{array}$ & Native & $\begin{array}{c}\text { Ephemer } \\
\text { optera }\end{array}$ & 17 & $\begin{array}{c}20^{\circ} \mathrm{Cl} \\
\mathrm{hr}\end{array}$ & 6.7 & 27 & 20.3 & 32.5 \\
\hline $\begin{array}{c}\text { (Dallas and } \\
\text { Rivers- } \\
\text { Moore } \\
\text { 2012) }\end{array}$ & $\begin{array}{c}\text { Leptophle } \\
\text { biidae* }\end{array}$ & Native & $\begin{array}{c}\text { Ephemer } \\
\text { optera }\end{array}$ & 17 & $\begin{array}{c}20^{\circ} \mathrm{Cl} \\
\mathrm{hr}\end{array}$ & 6.9 & 24.1 & 17.2 & 33.5 \\
\hline $\begin{array}{l}\text { (Dallas and } \\
\text { Rivers- } \\
\text { Moore } \\
\text { 2012) }\end{array}$ & $\begin{array}{c}\text { Telagono } \\
\text { didae* }^{*}\end{array}$ & Native & $\begin{array}{c}\text { Ephemer } \\
\text { optera }\end{array}$ & 17 & $\begin{array}{c}20^{\circ} \mathrm{Cl} \\
\mathrm{hr}\end{array}$ & 6.4 & 21.6 & 15.2 & 32.9 \\
\hline (Dallas and & Tricorythi & Native & Ephemer & 17 & $20^{\circ} \mathrm{C} /$ & 10. & 30.1 & 19.8 & 38.5 \\
\hline
\end{tabular}




\begin{tabular}{|c|c|c|c|c|c|c|c|c|c|}
\hline $\begin{array}{l}\text { Rivers- } \\
\text { Moore } \\
\text { 2012) }\end{array}$ & $d a e^{*}$ & & optera & & $\mathrm{hr}$ & 3 & & & \\
\hline $\begin{array}{c}\text { (Dallas and } \\
\text { Rivers- } \\
\text { Moore } \\
\text { 2012) } \\
\end{array}$ & $\begin{array}{c}\text { Notonecti } \\
\text { dae* }\end{array}$ & Native & $\begin{array}{c}\text { Hemipter } \\
\text { a }\end{array}$ & 17 & $\begin{array}{c}20^{\circ} \mathrm{C} / \\
\mathrm{hr}\end{array}$ & 6.9 & 24.1 & 17.2 & 40.7 \\
\hline $\begin{array}{c}\text { (Dallas and } \\
\text { Rivers- } \\
\text { Moore } \\
\text { 2012) } \\
\end{array}$ & Pleidae* & Native & $\begin{array}{c}\text { Hemipter } \\
\text { a }\end{array}$ & 17 & $\begin{array}{c}20^{\circ} \mathrm{C} / \\
\mathrm{hr}\end{array}$ & 9.8 & 27 & 17.2 & 38.5 \\
\hline $\begin{array}{l}\text { (Dallas and } \\
\text { Rivers- } \\
\text { Moore } \\
\text { 2012) }\end{array}$ & $\begin{array}{c}\text { Corydalid } \\
\text { ae* }\end{array}$ & Native & $\begin{array}{c}\text { Megalopt } \\
\text { era }\end{array}$ & 17 & $\begin{array}{c}20^{\circ} \mathrm{Cl} \\
\mathrm{hr}\end{array}$ & 6.9 & 24.1 & 17.2 & 35.6 \\
\hline $\begin{array}{c}\text { (Dallas and } \\
\text { Rivers- } \\
\text { Moore } \\
\text { 2012) } \\
\end{array}$ & $\begin{array}{c}\text { Aeschnid } \\
a e^{*}\end{array}$ & Native & Odonata & 17 & $\begin{array}{c}20^{\circ} \mathrm{Cl} \\
\mathrm{hr}\end{array}$ & 6.9 & 24.1 & 17.2 & 37.9 \\
\hline $\begin{array}{c}\text { (Dallas and } \\
\text { Rivers- } \\
\text { Moore } \\
\text { 2012) } \\
\end{array}$ & $\begin{array}{c}\text { Coenagrio } \\
\text { nidae* }\end{array}$ & Native & Odonata & 17 & $\begin{array}{c}20^{\circ} \mathrm{C} / \\
\mathrm{hr}\end{array}$ & 9.4 & 21.3 & 11.9 & 40.8 \\
\hline $\begin{array}{l}\text { (Dallas and } \\
\text { Rivers- } \\
\text { Moore } \\
\text { 2012) } \\
\end{array}$ & $\begin{array}{c}\text { Notonemo } \\
\text { uridae** }\end{array}$ & Native & $\begin{array}{c}\text { Plecopter } \\
\text { a }\end{array}$ & 17 & $\begin{array}{c}20^{\circ} \mathrm{Cl} \\
\mathrm{hr}\end{array}$ & $\begin{array}{c}12 . \\
2\end{array}$ & 21.5 & 9.3 & 29.9 \\
\hline $\begin{array}{c}\text { (Dallas and } \\
\text { Rivers- } \\
\text { Moore } \\
\text { 2012) } \\
\end{array}$ & $\begin{array}{c}\text { Hydropsy } \\
\text { chidae* }^{*}\end{array}$ & Native & $\begin{array}{c}\text { Trichopte } \\
\text { ra }\end{array}$ & 17 & $\begin{array}{c}20^{\circ} \mathrm{C} / \\
\mathrm{hr}\end{array}$ & 6.9 & 24.1 & 17.2 & 32.9 \\
\hline $\begin{array}{l}\text { (Dallas and } \\
\text { Rivers- } \\
\text { Moore } \\
\text { 2012) }\end{array}$ & $\begin{array}{c}\text { Leptoceri } \\
\text { dae* }\end{array}$ & Native & $\begin{array}{c}\text { Trichopte } \\
\text { ra }\end{array}$ & 17 & $\begin{array}{c}20^{\circ} \mathrm{Cl} \\
\mathrm{hr}\end{array}$ & 6 & 18.4 & 12.4 & 32 \\
\hline $\begin{array}{c}\text { (Dallas and } \\
\text { Rivers- } \\
\text { Moore } \\
\text { 2012) } \\
\end{array}$ & $\begin{array}{c}\text { Petrothrini } \\
\text { cidae* }^{*}\end{array}$ & Native & $\begin{array}{c}\text { Trichopte } \\
\text { ra }\end{array}$ & 17 & $\begin{array}{c}20^{\circ} \mathrm{C} / \\
\mathrm{hr}\end{array}$ & 9.4 & 21.3 & 11.9 & 31.6 \\
\hline $\begin{array}{c}\text { (Dallas and } \\
\text { Rivers- } \\
\text { Moore } \\
\text { 2012) }\end{array}$ & $\begin{array}{c}\text { Philopota } \\
\text { midae }^{*}\end{array}$ & Native & $\begin{array}{c}\text { Trichopte } \\
\text { ra }\end{array}$ & 17 & $\begin{array}{c}20^{\circ} \mathrm{C} / \\
\mathrm{hr}\end{array}$ & 6.9 & 24.1 & 17.2 & 32 \\
\hline $\begin{array}{c}\text { (Kennedy } \\
\text { and } \\
\text { Mihursky } \\
\text { 1971) } \\
\end{array}$ & $\begin{array}{c}\text { Mya } \\
\text { arenaria }\end{array}$ & Native & Bivalve & 30 & $\begin{array}{c}\text { not } \\
\text { listed }\end{array}$ & 2.8 & 26.8 & 24 & 34.4 \\
\hline $\begin{array}{l}\text { Kennedy } \\
\text { and } \\
\text { Mihursky } \\
\text { 1971) }\end{array}$ & $\begin{array}{l}\text { Gemma } \\
\text { gemma }\end{array}$ & Native & Bivalve & 30 & $\begin{array}{c}\text { not } \\
\text { listed }\end{array}$ & 4.1 & 26.8 & 22.7 & 37 \\
\hline $\begin{array}{l}\text { Kennedy } \\
\text { and }\end{array}$ & $\begin{array}{c}\text { Mulinia } \\
\text { lateralis }\end{array}$ & Native & Bivalve & 25 & $\begin{array}{c}\text { not } \\
\text { listed }\end{array}$ & 1.8 & 24 & 22.2 & 33.5 \\
\hline
\end{tabular}




\begin{tabular}{|c|c|c|c|c|c|c|c|c|c|}
$\begin{array}{c}\text { Mihursky } \\
\text { 1971) }\end{array}$ & & & & & & & & & \\
\hline $\begin{array}{c}\text { Kennedy } \\
\text { and } \\
\text { Mihursky } \\
\text { 1971) }\end{array}$ & $\begin{array}{c}\text { Macoma } \\
\text { bathica }\end{array}$ & Native & Bivalve & 30 & $\begin{array}{c}\text { not } \\
\text { listed }\end{array}$ & 2.3 & 30 & 27.7 & 34.1 \\
\hline
\end{tabular}

TABLE 5.1 TABLE LISTING THE SPECIES, TAXON, HIGH AND LOW GEOGRAPHIC THERMAL LIMITS, ORIGIN- NATIVE OR INVASIVE, RAMPING RATE, AND LT50 VALUE. THOSE NAMES MARKED WITH * REPRESENT FAMILY LEVEL TAXONOMIC IDENTIFICATION.

The upper thermal extreme experienced in nature is correlated to the upper thermal tolerance threshold

A comparison investigating the relationship between upper environmental temperature experienced in situ and upper thermal tolerance (LT50) was conducted (as described in Stillman and Somero, 2000; Zerebecki and Sorte, 2011). Table 5.1 lists the upper temperature that each species experiences in nature, and the laboratory derived LT50. A regression analysis using these data was conducted to assess the relationship between upper lethal thermal tolerance and the highest temperature each species experiences in nature.

Protein chaperone expression is greater in invasive than in native species

Given the methodological inconsistencies of Hsp measurements, e.g. mRNA vs. protein expression, a meta-analysis is not possible. However, there are a few research articles directly comparing Hsp expression between invasive species and their native congeners. I used these data to test the hypothesis that Hsp expression is greater in invasive organisms than in native ones. I also reviewed the temperature of induction of the heat shock response, $T_{\text {on }}$, and the temperature that produced the greatest expression of Hsp's, $T_{\max }$, which varies 
across thermally heterogeneous environments (Tomanek and Somero 1999). This approach provided further evidence that Hsp production is partially responsible for thermal tolerance thresholds in ectotherms. Table 5.2 lists the citation, species, type of Hsp measured (Hsp 70, 90, etc.), gene expression type (mRNA, protein), maximum Hsp expression level measured, $T_{\text {on }}$ and $T_{\max }$, and the statistical error associated with the measurement variable. Summary statistics were performed to compare $T_{\text {on }}$ and $T_{\max }$ values between native and invasive organisms.

\begin{tabular}{|c|c|c|c|c|c|c|c|c|c|}
\hline $\begin{array}{l}\frac{9}{7 !} \\
\frac{0}{*} \\
\frac{0}{2}\end{array}$ & 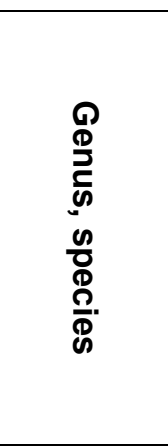 & $\frac{0}{\frac{1}{0}}$ & 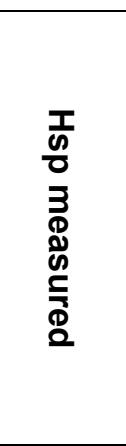 & 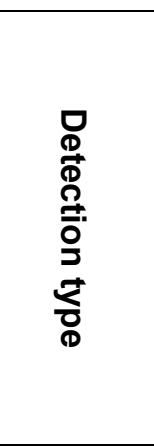 & $\begin{array}{l}-1 \\
\stackrel{0}{J} \\
0\end{array}$ & 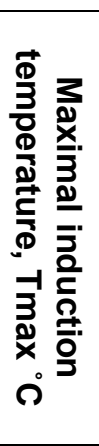 & 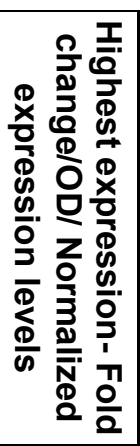 & 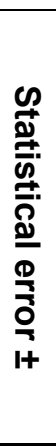 & 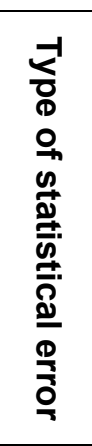 \\
\hline $\begin{array}{c}\text { (Hofmann } \\
\text { and } \\
\text { Somero } \\
\text { 1996a) }\end{array}$ & $\begin{array}{l}\text { Mytilus } \\
\text { trossulus }\end{array}$ & Native & Hsp70 & $\begin{array}{l}\text { In vitro } \\
\text { radio } \\
\text { labeling }\end{array}$ & 23 & & & & \\
\hline $\begin{array}{c}\text { (Hofmann } \\
\text { and } \\
\text { Somero } \\
\text { 1996a) }\end{array}$ & $\begin{array}{c}\text { Mytilus } \\
\text { galloprovi } \\
\text { ncialis }\end{array}$ & Invasive & Hsp70 & $\begin{array}{l}\text { In vitro } \\
\text { radio } \\
\text { labeling }\end{array}$ & 25 & & & & \\
\hline $\begin{array}{c}\text { (Zerebeck } \\
\text { i and } \\
\text { Sorte } \\
2011)\end{array}$ & $\begin{array}{c}\text { Diplosom } \\
a \\
\text { listerianu } \\
m\end{array}$ & Invasive & Hsp70 & $\begin{array}{c}\text { Western } \\
\text { blot }\end{array}$ & 16 & 31 & 0.93 & 0 & $\begin{array}{l}\text { Std. } \\
\text { error }\end{array}$ \\
\hline
\end{tabular}




\begin{tabular}{|c|c|c|c|c|c|c|c|c|c|}
\hline $\begin{array}{c}\text { (Zerebeck } \\
\text { i and } \\
\text { Sorte } \\
2011)\end{array}$ & $\begin{array}{c}\text { Distaplia } \\
\text { occidenta } \\
\text { lis }\end{array}$ & Native & Hsp70 & $\begin{array}{c}\text { Western } \\
\text { blot }\end{array}$ & 16 & 16 & 0.42 & 0.2 & $\begin{array}{l}\text { Std. } \\
\text { error }\end{array}$ \\
\hline $\begin{array}{c}\text { (Yu et al. } \\
\text { 2012) }\end{array}$ & $\begin{array}{c}\text { Bemisia } \\
\text { tabaci } \\
\text { ZHJ1 }\end{array}$ & Native & Hsp70 & $\begin{array}{c}\text { mRNA, } \\
\text { Gene } \\
\text { expressio } \\
n\end{array}$ & 37 & 39 & 1.5 & 0 & $\begin{array}{l}\text { Std. } \\
\text { dev. }\end{array}$ \\
\hline $\begin{array}{c}\text { (Yu et al. } \\
\text { 2012) }\end{array}$ & $\begin{array}{c}\text { Bemisia } \\
\text { tabaci } \\
\text { ZHJ1 }\end{array}$ & Native & Hsp90 & $\begin{array}{c}\text { mRNA, } \\
\text { Gene } \\
\text { expressio } \\
n\end{array}$ & 35 & 41 & 3.6 & 0.7 & $\begin{array}{l}\text { Std. } \\
\text { dev. }\end{array}$ \\
\hline $\begin{array}{c}\text { Yu, } 2012 \\
\text { (Yu et al. } \\
\text { 2012) }\end{array}$ & $\begin{array}{c}\text { Bemisia } \\
\text { tabaci } \\
\text { ZHJ1 }\end{array}$ & Native & Hsp20 & $\begin{array}{c}\text { mRNA, } \\
\text { Gene } \\
\text { expressio } \\
n\end{array}$ & 37 & 39 & 2.7 & 0.9 & $\begin{array}{l}\text { Std. } \\
\text { dev. }\end{array}$ \\
\hline $\begin{array}{c}\text { Yu, } 2012 \\
\text { (Yu et al. } \\
\text { 2012) }\end{array}$ & $\begin{array}{l}\text { Bemisia } \\
\text { tabaci Q }\end{array}$ & Invasive & Hsp70 & $\begin{array}{c}\text { mRNA, } \\
\text { Gene } \\
\text { expressio } \\
n\end{array}$ & 39 & 43 & 6.3 & 1.8 & $\begin{array}{l}\text { Std. } \\
\text { dev. }\end{array}$ \\
\hline $\begin{array}{c}\text { Yu, } 2012 \\
\text { (Yu et al. } \\
\text { 2012) }\end{array}$ & $\begin{array}{l}\text { Bemisia } \\
\text { tabaci Q }\end{array}$ & Invasive & Hsp90 & $\begin{array}{c}\text { mRNA, } \\
\text { Gene } \\
\text { expressio } \\
n\end{array}$ & 35 & 43 & 6.4 & 0.7 & $\begin{array}{l}\text { Std. } \\
\text { dev. }\end{array}$ \\
\hline $\begin{array}{c}\text { Yu, } 2012 \\
\text { (Yu et al. } \\
\text { 2012) }\end{array}$ & $\begin{array}{l}\text { Bemisia } \\
\text { tabaci Q }\end{array}$ & Invasive & Hsp20 & $\begin{array}{c}\text { mRNA, } \\
\text { Gene } \\
\text { expressio } \\
n\end{array}$ & 37 & 41 & 10 & 3 & $\begin{array}{l}\text { Std. } \\
\text { dev. }\end{array}$ \\
\hline $\begin{array}{l}\text { (Lockwoo } \\
\text { d et al. } \\
2010 \text { ) }\end{array}$ & $\begin{array}{l}\text { Mytilus } \\
\text { trossulus }\end{array}$ & Native & Hsp20 & $\begin{array}{c}\text { mRNA, } \\
\text { Gene } \\
\text { expressio } \\
n\end{array}$ & & & 1.5 & 0.3 & $\begin{array}{l}\text { Std. } \\
\text { error }\end{array}$ \\
\hline $\begin{array}{c}\text { (Lockwoo } \\
\text { d et al. } \\
2010 \text { ) }\end{array}$ & $\begin{array}{c}\text { Mytilus } \\
\text { galloprovi } \\
\text { ncialis }\end{array}$ & Invasive & Hsp20 & $\begin{array}{c}\text { mRNA, } \\
\text { Gene } \\
\text { expressio } \\
n\end{array}$ & & & 6.6 & 0.7 & $\begin{array}{l}\text { Std. } \\
\text { error }\end{array}$ \\
\hline $\begin{array}{l}\text { (Henkel } \\
\text { and } \\
\text { Hofmann } \\
\text { 2008) }\end{array}$ & $\begin{array}{c}\text { Undaria } \\
\text { pinnatifid } \\
\text { a }\end{array}$ & Invasive & Hsp70 & $\begin{array}{c}\text { mRNA, } \\
\text { Gene } \\
\text { expressio } \\
n\end{array}$ & 22 & 26 & 12.9 & 9.7 & $\begin{array}{l}\text { Std. } \\
\text { error }\end{array}$ \\
\hline
\end{tabular}




\begin{tabular}{|c|c|c|c|c|c|c|c|c|c|}
\hline $\begin{array}{l}\text { (Henkel } \\
\text { and } \\
\text { Hofmann } \\
\text { 2008) }\end{array}$ & $\begin{array}{c}\text { Egregia } \\
\text { menziesii }\end{array}$ & Native & Hsp70 & $\begin{array}{c}\text { mRNA, } \\
\text { Gene } \\
\text { expressio } \\
n\end{array}$ & 17 & 17 & 2.3 & 0.2 & $\begin{array}{l}\text { Std. } \\
\text { error }\end{array}$ \\
\hline
\end{tabular}

Acclimation to warmer temperatures facilitates a greater range of thermal tolerance for invasives compared to native organisms

To test this hypothesis, I explored the link between the range of laboratory temperature acclimation a species experienced and the change in upper thermal tolerance, LT50, which was measured. An appropriate metric for evaluating how acclimation alters upper thermal tolerance is the Acclimation Response Ratio (ARR). The ARR estimates the ability of organisms to alter upper thermal tolerance values with changing acclimation temperature (Claussen1977). I calculated the ARR for each species by taking the difference between the high and low LT50 at each acclimation temperature $(\Delta$ LT50), and then dividing that value by the difference in the acclimation temperatures ( $\Delta$ acclimation $\left.{ }^{\circ} \mathrm{C}\right)$. For this analysis, only the published studies that listed the low and the high acclimation treatment temperature and the corresponding LT50 values were included. Table 5.3 lists the species, taxon, range (invasive or native) lower and upper acclimation temperature $\left({ }^{\circ} \mathrm{C}\right)$, the corresponding LT50 temperatures after acclimation to two temperatures $\left({ }^{\circ} \mathrm{C}\right), \Delta$ acclimation $\left({ }^{\circ} \mathrm{C}\right)$, and the $\Delta \mathrm{LT} 50$, and the ARR. ARR values were then grouped between native and invasive species, and a student's t-test was used to test for significant differences between the two 
groups. A Grubb's test for outliers identified a single outlier (ARR for the native Ellipsaria lineolata) which was removed from the data analysis.

\begin{tabular}{|c|c|c|c|c|c|c|c|c|c|c|}
\hline $\begin{array}{l}\frac{\rho}{+0} \\
\frac{\overrightarrow{0}}{\overrightarrow{0}} \\
\frac{0}{2}\end{array}$ & 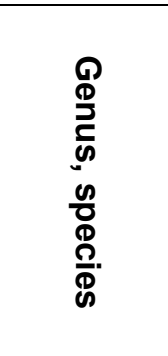 & $\begin{array}{l}-1 \\
\stackrel{x}{x} \\
0 \\
0\end{array}$ & 음. & 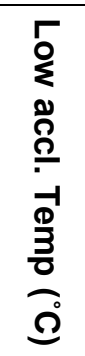 & 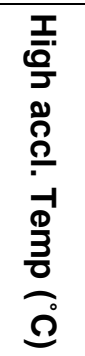 & 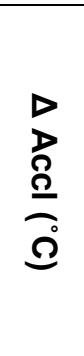 & 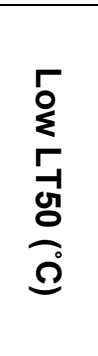 & 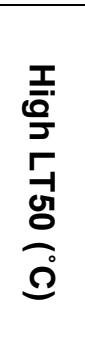 & $\begin{array}{l}\triangleright \\
\text { 당 } \\
\text { 잉 }\end{array}$ & 另 \\
\hline $\begin{array}{l}\text { (Kelley } \\
\text { et al. } \\
\text { 2011) }\end{array}$ & $\begin{array}{c}\text { Carcinus } \\
\text { maenas }\end{array}$ & Decapod & Invasive & 6.0 & 23.0 & 17.0 & 31.7 & 35.5 & 3.8 & 0.2 \\
\hline $\begin{array}{c}\text { (Díaz } \\
\text { Herrer } \\
\text { a et al. } \\
1998)\end{array}$ & $\begin{array}{c}\text { Macrobr } \\
\text { achium } \\
\text { rosenber } \\
\text { gii }\end{array}$ & Decapod & Invasive & 20.0 & 32.0 & 12.0 & 37.3 & 41.6 & 4.3 & 0.4 \\
\hline $\begin{array}{l}\text { Slabb } \\
\text { er et } \\
\text { al. } \\
2007)\end{array}$ & $\begin{array}{c}\text { Pogonog } \\
\text { nathellus } \\
\text { flavesce } \\
n s\end{array}$ & Springtail & Invasive & -2.2 & 12.7 & 14.9 & 32.7 & 35.1 & 2.4 & 0.2 \\
\hline $\begin{array}{c}\text { (Slabb } \\
\text { er et } \\
\text { al. } \\
2007)\end{array}$ & $\begin{array}{c}\text { Isotomur } \\
\text { us } \\
\text { palustris }\end{array}$ & Springtail & Invasive & -1.1 & 13.9 & 15.0 & 33.6 & 33.6 & 0.1 & 0.0 \\
\hline $\begin{array}{l}\text { (Slabb } \\
\text { er et } \\
\text { al. } \\
2007) \\
\end{array}$ & $\begin{array}{c}\text { Ceratop } \\
\text { hysella } \\
\text { Denticul } \\
\text { ata }\end{array}$ & Springtail & Invasive & 0.1 & 15.0 & 15.0 & 35.4 & 36.7 & 1.3 & 0.1 \\
\hline $\begin{array}{c}\text { (Braby } \\
\text { and } \\
\text { Somer } \\
\text { o } \\
2006 b) \\
\end{array}$ & $\begin{array}{c}\text { Mytilus } \\
\text { Gallopriv } \\
\text { inciallis }\end{array}$ & Mytilus & Invasive & 14.0 & 21.0 & 7.0 & 25.7 & 30.9 & 5.2 & 0.7 \\
\hline $\begin{array}{l}\text { (Mills } \\
\text { et al. } \\
\text { 1996) }\end{array}$ & $\begin{array}{c}\text { Dreissen } \\
\text { a } \\
\text { polymor } \\
\text { pha }\end{array}$ & Bivalve & Invasive & 5.0 & 20.0 & 15.0 & 35.0 & 36.2 & 1.2 & 0.1 \\
\hline $\begin{array}{l}\text { (Mills } \\
\text { et al. } \\
\text { 1996) }\end{array}$ & $\begin{array}{c}\text { Dreissen } \\
\text { a } \\
\text { bugensis }\end{array}$ & Bivalve & Invasive & 5.0 & 20.0 & 15.0 & 30.9 & 35.1 & 4.2 & 0.3 \\
\hline $\begin{array}{c}\text { (Jumb } \\
\text { am et } \\
\text { al. } \\
2008 b)\end{array}$ & $\begin{array}{c}\text { Linepithe } \\
\text { ma } \\
\text { humile }\end{array}$ & $\begin{array}{c}\text { Hymenop } \\
\text { tera }\end{array}$ & Invasive & 15.0 & 25.0 & 10.0 & 37.8 & 40.0 & 2.2 & 0.2 \\
\hline $\begin{array}{c}\text { (Jumb } \\
\text { am et } \\
\text { al. }\end{array}$ & $\begin{array}{c}\text { Prinerigo } \\
\text { ne } \\
\text { vagans }\end{array}$ & $\begin{array}{c}\text { Arachnid } \\
\text { a }\end{array}$ & Invasive & 0.0 & 15.0 & 15.0 & 35.4 & 35.9 & 0.5 & 0.0 \\
\hline
\end{tabular}




\begin{tabular}{|c|c|c|c|c|c|c|c|c|c|c|}
\hline 2008a) & & & & & & & & & & \\
\hline $\begin{array}{l}\text { (Kumlu } \\
\text { et al. } \\
2010)\end{array}$ & $\begin{array}{l}\text { Litopena } \\
\text { eus } \\
\text { vannam } \\
\text { ei }\end{array}$ & $\begin{array}{c}\text { Malacost } \\
\text { raca }\end{array}$ & Invasive & 15.0 & 30.0 & 15.0 & 35.9 & 42.2 & 6.3 & 0.4 \\
\hline $\begin{array}{l}\text { (Currie } \\
\text { et al. } \\
1998)\end{array}$ & $\begin{array}{c}\text { Micropte } \\
\text { rus } \\
\text { salmoide } \\
\text { s }\end{array}$ & Teleost & Invasive & 20.0 & 30.0 & 10.0 & 35.4 & 38.5 & 3.1 & 0.3 \\
\hline $\begin{array}{l}\text { (Currie } \\
\text { et al. } \\
1998)\end{array}$ & $\begin{array}{c}\text { Ictalurus } \\
\text { punctatu } \\
s\end{array}$ & Teleost & Invasive & 20.0 & 30.0 & 10.0 & 36.4 & 40.3 & 3.9 & 0.4 \\
\hline $\begin{array}{l}\text { (Cowli } \\
\text { ng et } \\
\text { al. } \\
2003)\end{array}$ & $\begin{array}{c}\text { Arcitalitr } \\
\text { us } \\
\text { dorrieni }\end{array}$ & $\begin{array}{c}\text { Amphipo } \\
\text { d }\end{array}$ & Invasive & 10.0 & 20.0 & 10.0 & 33.2 & 33.7 & 0.5 & 0.1 \\
\hline $\begin{array}{l}\text { (Slabb } \\
\text { er et } \\
\text { al. } \\
2007)\end{array}$ & $\begin{array}{c}\text { C. } \\
\text { antarctic } \\
\text { us travei }\end{array}$ & Springtail & Native & 1.2 & 16.2 & 15.0 & 32.7 & 30.8 & -1.9 & -0.1 \\
\hline $\begin{array}{l}\text { (Slabb } \\
\text { er et } \\
\text { al. } \\
2007)\end{array}$ & $\begin{array}{c}\text { Tullbergi } \\
a \\
\text { bisetosa }\end{array}$ & Springtail & Native & 2.3 & 17.3 & 15.0 & 30.1 & 31.3 & 1.1 & 0.1 \\
\hline $\begin{array}{l}\text { (Braby } \\
\text { and } \\
\text { Somer } \\
\text { o } \\
2006 b)\end{array}$ & $\begin{array}{l}\text { Mytilus } \\
\text { trossulus }\end{array}$ & Bivalve & Native & 14.0 & 21.0 & 7.0 & 24.2 & 26.0 & 1.8 & 0.3 \\
\hline $\begin{array}{l}\text { (Braby } \\
\text { and } \\
\text { Somer } \\
\text { o } \\
2006 b)\end{array}$ & $\begin{array}{l}\text { Mytilus } \\
\text { edulis }\end{array}$ & Bivalve & Native & 14.0 & 21.0 & 7.0 & 24.2 & 28.9 & 4.7 & 0.7 \\
\hline $\begin{array}{l}\text { (Billma } \\
\text { n et al. } \\
2008)\end{array}$ & $\begin{array}{c}\text { Snyderic } \\
\text { hthys } \\
\text { copei }\end{array}$ & Teleost & Native & 15.0 & 28.0 & 13.0 & 29.6 & 35.0 & 5.4 & 0.4 \\
\hline $\begin{array}{c}\text { (Jumb } \\
\text { am et } \\
\text { al. } \\
2008 a)\end{array}$ & $\begin{array}{c}\text { Myro } \\
\text { kerguele } \\
\text { nensis }\end{array}$ & $\begin{array}{c}\text { Arachnid } \\
a\end{array}$ & Native & 0.0 & 15.0 & 15.0 & 35.2 & 35.4 & 0.2 & 0.0 \\
\hline $\begin{array}{l}\text { (Pando } \\
\text { Ifo et } \\
\text { al. } \\
2010)\end{array}$ & $\begin{array}{c}\text { Lampsili } \\
\text { s } \\
\text { siliquoid } \\
\text { ea }\end{array}$ & Bivalve & Native & 22.0 & 27.0 & 5.0 & 35.6 & 34.4 & -1.2 & -0.2 \\
\hline $\begin{array}{l}\text { (Pando } \\
\text { Ifo et } \\
\text { al. } \\
2010)\end{array}$ & $\begin{array}{c}\text { Potamilu } \\
\text { s alatus }\end{array}$ & Bivalve & Native & 22.0 & 27.0 & 5.0 & 35.0 & 34.1 & -0.9 & -0.2 \\
\hline
\end{tabular}




\begin{tabular}{|c|c|c|c|c|c|c|c|c|c|c|}
\hline $\begin{array}{l}\text { (Pando } \\
\text { Ifo et } \\
\text { al. } \\
2010)\end{array}$ & $\begin{array}{l}\text { Ligumia } \\
\text { recta }\end{array}$ & Bivalve & Native & 22.0 & 27.0 & 5.0 & 32.5 & 35.1 & 2.6 & 0.5 \\
\hline $\begin{array}{l}\text { (Pando } \\
\text { Ifo et } \\
\text { al. } \\
2010)\end{array}$ & $\begin{array}{l}\text { Ellipsaria } \\
\text { lineolata }\end{array}$ & Bivalve & Native & 22.0 & 27.0 & 5.0 & 38.8 & 33.1 & -5.7 & -1.1 \\
\hline $\begin{array}{l}\text { (Pando } \\
\text { Ifo et } \\
\text { al. } \\
2010)\end{array}$ & $\begin{array}{c}\text { Megalon } \\
\text { aias } \\
\text { nervosa }\end{array}$ & Bivalve & Native & 22.0 & 27.0 & 5.0 & 34.2 & 34.0 & -0.2 & 0.0 \\
\hline $\begin{array}{l}\text { (Pando } \\
\text { Ifo et } \\
\text { al. } \\
2010) \\
\end{array}$ & $\begin{array}{l}\text { Alasmid } \\
\text { onta } \\
\text { varicosa }\end{array}$ & Bivalve & Native & 22.0 & 27.0 & 5.0 & 35.0 & 35.1 & 0.1 & 0.0 \\
\hline $\begin{array}{l}\text { (Pando } \\
\text { Ifo et } \\
\text { al. } \\
2010) \\
\end{array}$ & $\begin{array}{c}\text { Villosa } \\
\text { delumbis }\end{array}$ & Bivalve & Native & 22.0 & 27.0 & 5.0 & 34.6 & 34.2 & -0.4 & -0.1 \\
\hline $\begin{array}{c}\text { (Kenne } \\
\text { dy and } \\
\text { Mihurs } \\
\text { ky } \\
1971)\end{array}$ & $\begin{array}{c}\text { Mya } \\
\text { arenaria }\end{array}$ & Bivalve & Native & 5.0 & 30.0 & 25.0 & 30.9 & 34.4 & 3.5 & 0.1 \\
\hline $\begin{array}{c}\text { (Kenne } \\
\text { dy and } \\
\text { Mihurs } \\
\text { ky } \\
1971)\end{array}$ & $\begin{array}{l}\text { Gemma } \\
\text { gemma }\end{array}$ & Bivalve & Native & 5.0 & 30.0 & 25.0 & 35.6 & 37.0 & 1.4 & 0.1 \\
\hline $\begin{array}{c}\text { (Kenne } \\
\text { dy and } \\
\text { Mihurs } \\
\text { ky } \\
1971)\end{array}$ & $\begin{array}{c}\text { Mulinia } \\
\text { lateralis }\end{array}$ & Bivalve & Native & 2.0 & 25.0 & 23.0 & 30.2 & 33.5 & 3.3 & 0.1 \\
\hline $\begin{array}{c}\text { (Kenne } \\
\text { dy and } \\
\text { Mihurs } \\
\text { ky } \\
1971)\end{array}$ & $\begin{array}{c}\text { Macoma } \\
\text { bathica }\end{array}$ & Bivalve & Native & 5.0 & 30.0 & 25.0 & 31.2 & 34.1 & 2.9 & 0.1 \\
\hline $\begin{array}{c}\text { (Kenne } \\
\text { dy and } \\
\text { Mihurs } \\
\text { ky } \\
1971)\end{array}$ & $\begin{array}{c}\text { Gambusi } \\
\text { a affinis }\end{array}$ & Teleost & Invasive & 25.0 & 30.0 & 5.0 & 40.7 & 42.1 & 1.4 & 0.3 \\
\hline $\begin{array}{c}\text { (Kenne } \\
\text { dy and } \\
\text { Mihurs } \\
\text { ky } \\
1971)\end{array}$ & $\begin{array}{c}\text { Cyprinell } \\
a \\
\text { lutrensis }\end{array}$ & Teleost & Invasive & 25.0 & 30.0 & 5.0 & 39.5 & 40.9 & 1.4 & 0.3 \\
\hline $\begin{array}{l}\text { (Carvet } \\
\mathrm{h} \text { et al. }\end{array}$ & $\begin{array}{c}\text { Agosia } \\
\text { chrysoga }\end{array}$ & Teleost & Native & 25.0 & 30.0 & 5.0 & 38.9 & 41.1 & 2.2 & 0.4 \\
\hline
\end{tabular}




\begin{tabular}{|c|c|c|c|c|c|c|c|c|c|c|}
\hline 2006) & ster & & & & & & & & & \\
\hline $\begin{array}{l}\text { (Carvet } \\
\text { h et al. } \\
2006)\end{array}$ & $\begin{array}{c}\text { Lepomis } \\
\text { cyanellu } \\
s\end{array}$ & Teleost & Invasive & 25.0 & 30.0 & 5.0 & 39.3 & 41.5 & 2.2 & 0.4 \\
\hline $\begin{array}{l}\text { (Carvet } \\
\text { h et al. } \\
2006 \text { ) }\end{array}$ & $\begin{array}{l}\text { Lepomis. } \\
\text { Macrochi } \\
\text { rus }\end{array}$ & Teleost & Invasive & 25.0 & 30.0 & 5.0 & 37.3 & 39.6 & 2.3 & 0.5 \\
\hline $\begin{array}{l}\text { (Carvet } \\
\text { h et al. } \\
2006 \text { ) }\end{array}$ & $\begin{array}{l}\text { Meda } \\
\text { fulgida }\end{array}$ & Teleost & Native & 25.0 & 30.0 & 5.0 & 37.0 & 39.1 & 2.1 & 0.4 \\
\hline $\begin{array}{l}\text { (Carvet } \\
\text { h et al. } \\
2006 \text { ) }\end{array}$ & $\begin{array}{l}\text { Catosto } \\
\text { mus } \\
\text { clarkia }\end{array}$ & Teleost & Native & 25.0 & 30.0 & 5.0 & 36.9 & 37.6 & 0.7 & 0.1 \\
\hline $\begin{array}{l}\text { (Carvet } \\
\text { h et al. } \\
2006)\end{array}$ & $\begin{array}{l}\text { Rhinicht } \\
\text { hys } \\
\text { cobitis }\end{array}$ & Teleost & Native & 25.0 & 30.0 & 5.0 & 36.5 & 36.8 & 0.3 & 0.1 \\
\hline $\begin{array}{l}\text { (Carvet } \\
\text { h et al. } \\
2006 \text { ) }\end{array}$ & $\begin{array}{l}\text { Rhinicht } \\
\text { hys } \\
\text { osculus }\end{array}$ & Teleost & Native & 25.0 & 30.0 & 5.0 & 36.0 & 36.9 & 0.9 & 0.2 \\
\hline $\begin{array}{l}\text { (Carvet } \\
\text { h et al. } \\
2006 \text { ) }\end{array}$ & $\begin{array}{l}\text { Cyprinod } \\
\text { on } \\
\text { maculari } \\
\text { us }\end{array}$ & Teleost & Native & 25.0 & 30.0 & 5.0 & 41.8 & 42.7 & 0.9 & 0.2 \\
\hline $\begin{array}{l}\text { (Carvet } \\
\text { h et al. } \\
2006 \text { ) }\end{array}$ & $\begin{array}{l}\text { Poeciliop } \\
\text { sis } \\
\text { occident } \\
\text { alis }\end{array}$ & Teleost & Native & 25.0 & 30.0 & 5.0 & 39.4 & 42.1 & 2.7 & 0.5 \\
\hline $\begin{array}{l}\text { (Carvet } \\
h \text { et al. } \\
2006 \text { ) }\end{array}$ & $\begin{array}{c}\text { Gila } \\
\text { elegans }\end{array}$ & Teleost & Native & 25.0 & 30.0 & 5.0 & 38.7 & 40.2 & 1.5 & 0.3 \\
\hline $\begin{array}{l}\text { (Carvet } \\
\text { h et al. } \\
2006)\end{array}$ & $\begin{array}{c}\text { Gila } \\
\text { intermed } \\
\text { ia }\end{array}$ & Teleost & Native & 25.0 & 30.0 & 5.0 & 38.3 & 39.0 & 0.7 & 0.1 \\
\hline $\begin{array}{l}\text { (Carvet } \\
\mathrm{h} \text { et al. } \\
2006 \text { ) }\end{array}$ & $\begin{array}{c}\text { Xyrauch } \\
\text { en } \\
\text { texanus }\end{array}$ & Teleost & Native & 25.0 & 30.0 & 5.0 & 39.1 & 40.3 & 1.2 & 0.2 \\
\hline
\end{tabular}

TABLE 5.3 LISTS THE SPECIES, TAXON, RANGE (INVASIVE OR NATIVE) LOWER AND UPPER ACCLIMATION TEMPERATURE ( $\left({ }^{\circ} \mathrm{C}\right)$, THE CORRESPONDING LT50 TEMPERATURES AFTER ACCLIMATION TO TWO TEMPERATURES $\left({ }^{\circ} \mathrm{C}\right), \triangle$ ACCLIMATION ( $\left.{ }^{\circ} \mathrm{C}\right), \triangle$ LT50, AND THE ARR- ACCLIMATION RESPONSE RATIO.

\section{Results}

Range width is associated with broad physiological tolerance

I found that the thermal breadth an invasive population experienced across its geographic range (native and invasive) was positively correlated with its LT50 as measured in the laboratory (Fig. 5.1, R= 0.66, y= 0.581x +13.595 , 
$\mathrm{F}=11.0, \mathrm{n}=17, \mathrm{p}<0.005)$. Although not considered a statistical outlier, removing Bemisia tabaci from this analysis resulted in an $R=0.4(y=0.5207 x+15.367$, $\mathrm{F}=2.7, \mathrm{n}=16, \mathrm{p}=0.12$ ). There appeared to be a weak relationship for native organisms (Fig. 5.1, $R=0.260 .07, y=-0.256 x+38.226, F=2.0, n=30, p=0.167$ ). Furthermore, the thermal range experienced by the populations from their native ranges (mean $=19 \pm 1.5 \mathrm{SE}, \mathrm{n}=30$ ) was significantly lower than that of those from invaded ones (mean $=31.2^{\circ} \mathrm{C} \pm 1.5^{\circ} \mathrm{C}$ SE; $t$-test; $\left.t=7.7, n=17, p<0.0001\right)$.

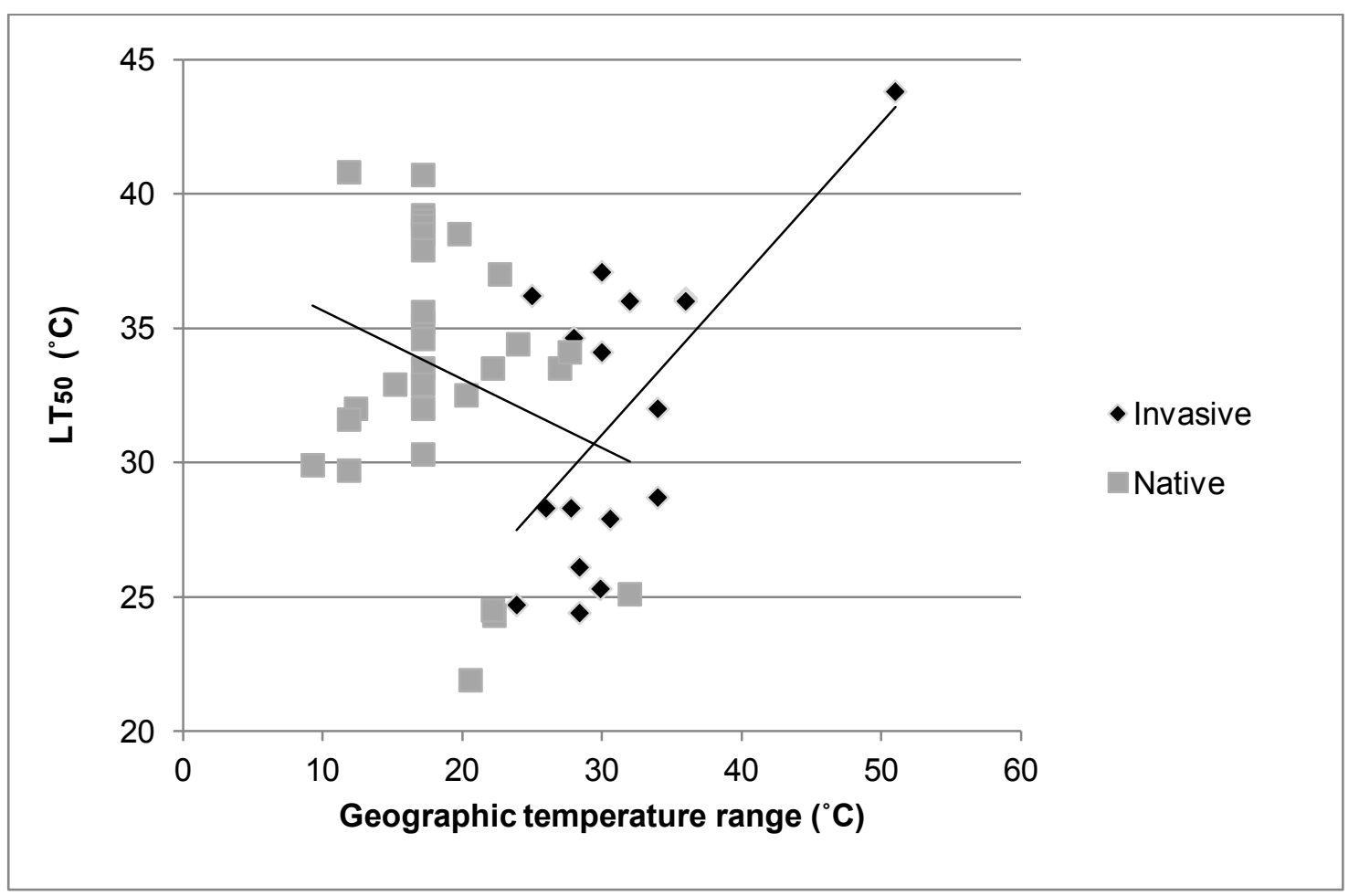

FIGURE 5.1 LINEAR REGRESSION ILLUSTRATING THE RELATIONSHIP BETWEEN GEOGRAPHIC THERMAL RANGE (NATIVE AND INVASIVE) AND THE LT50 OF TERRESTRIAL AND AQUATIC ECTOTHERMS (R FOR INVASIVES=0.66, FOR NATIVES R= $0.26)$.

The upper thermal extreme experienced in nature is correlated upper

thermal tolerance threshold 
For invasive ectotherms, a clear relationship emerged between geographic high temperature experienced and the upper lethal thermal tolerance, with the $R=0.70(y=0.862 x+3.147, F=15, n=17, p=0.0015)($ Fig. 5.2). With Bemisia tabaci removed from this analysis, $R=0.75(y=0.6967 x+8.3152, F=$ 6.8, $n=16, p=0.02$ ). Conversely, no relationship emerged between these two variables for native species $(R=0.04, y=0.075 x+31.616, F=0.058, n=30$, $p=0.81$ ) (Fig. 5.2). While the effect of temperature on LT50 values differed between the two groups, the range of LT50 values was similar for both groups and no significant difference was found between the LT50 values of natives versus invasives $(p=0.27)$. Additionally, the native species used in this analysis had generally high LT50 values, which likely drives the similarities between the two groups. Comparing LT50 values between natives and invasives within taxonomic groups highlights that invaders generally have slightly higher LT50's than natives of the same taxon. For example, the mean LT50 for invasive decapods is $35.1^{\circ} \mathrm{C}$ and $33.5^{\circ} \mathrm{C}$ for native decapods. Similarly for Hemiptera, the invasives mean LT50 is $43.8^{\circ} \mathrm{C}$, and for natives it is $39.6^{\circ} \mathrm{C}$. 


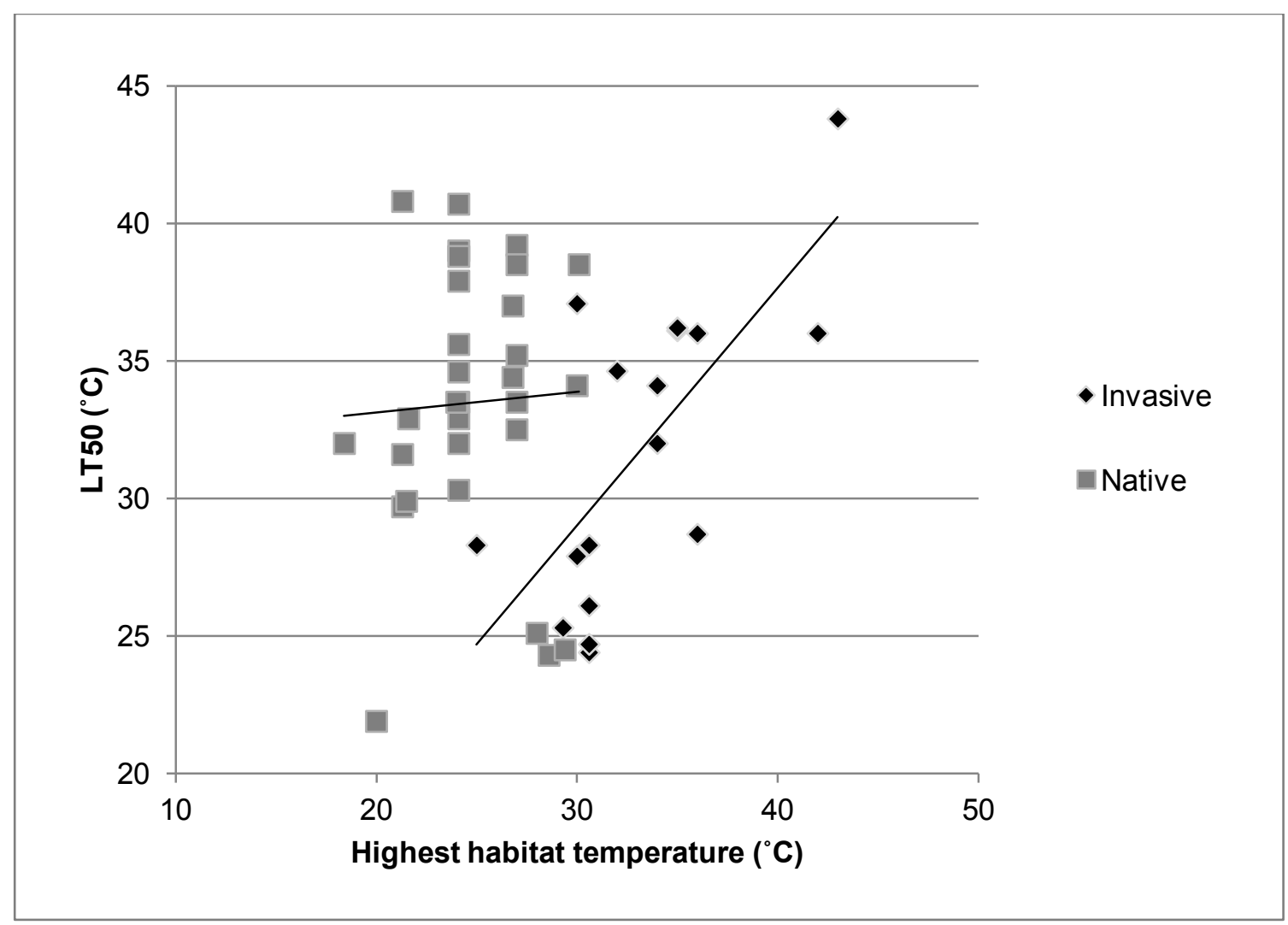

FIGURE 5.2 LINEAR REGRESSION ILLUSTRATING THE RELATIONSHIP BETWEEN HIGHEST HABITAT TEMPERATURE EXPERIENCED AND THE LABORATORY MEASURED LT50; FOR INVASIVE $R=0.70, Y=0.8624 X+3.1466$; FOR NATIVES $R=0.04, Y=0.075 X+$ 31.616.

Protein chaperone expression is greater in invasive than in native species These results support the hypothesis that invaders generally have a greater overall heat shock response, characterized by the greater maximal expression, and the higher induction temperature (Table 5.2, Figure 5.2). $T_{\text {on }}$ (the temperature that induces Hsp expression) was $2.2 \pm 1.7^{\circ} \mathrm{C}$ higher for invasives when compared to native species. Likewise, $\mathrm{T}_{\max }$ was $6.8 \pm 5.2^{\circ} \mathrm{C}$ higher in invasives than in natives. Figure 5.3 compares the maximal expression of Hsp 70 between invasive and native species. This analysis includes 4 distinct taxonomic 
groups, including Hemiptera, Tunicate, Bivalve, and Macrophyte, and in every comparison, invaders had greater expression levels than natives. In addition, this pattern was seen in three different Hsp classes, Hsp70, Hsp20, and Hsp90 (Fig $5.3,5.4,5.5)$.
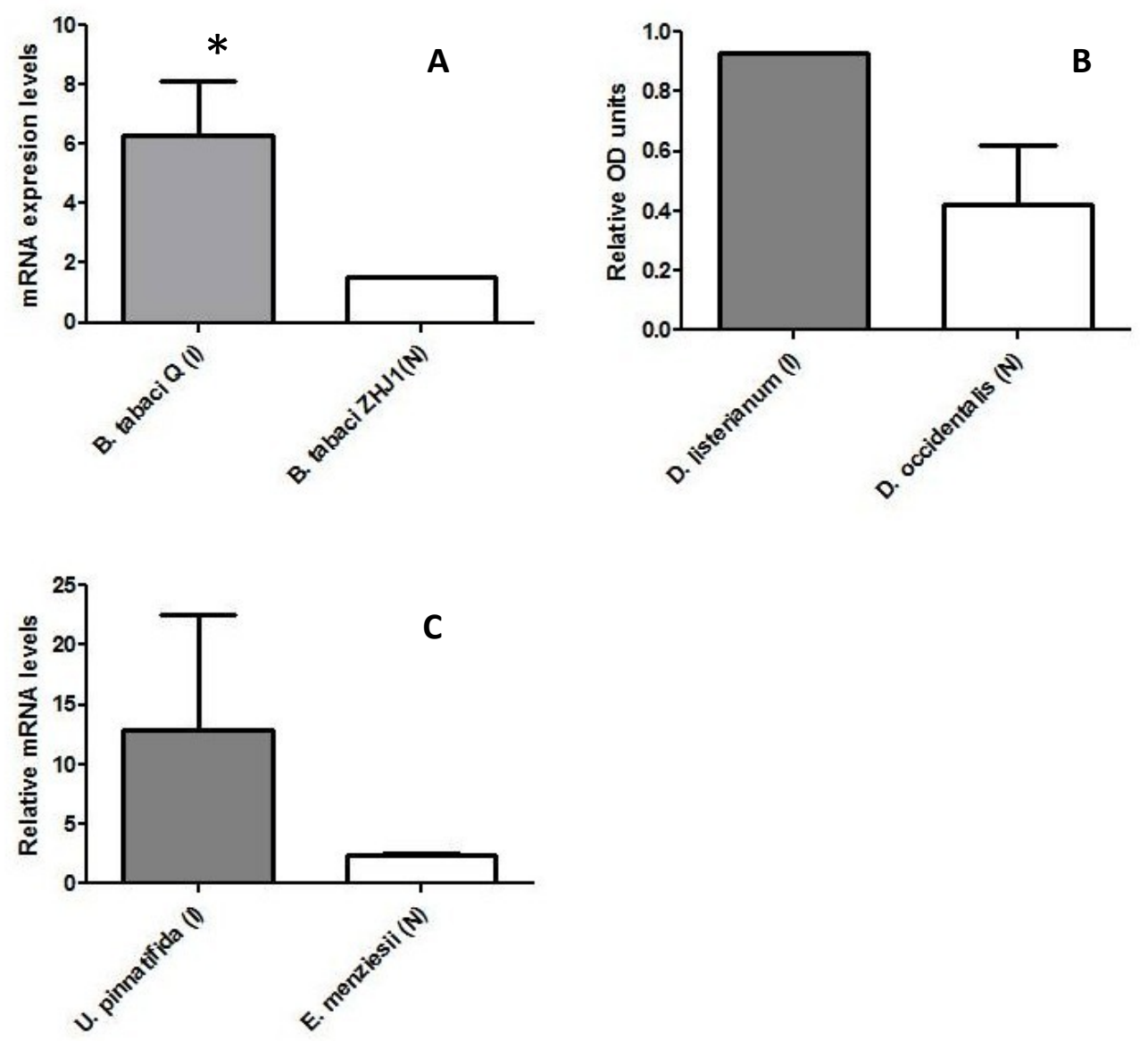

FIGURE 5.3 MAXIMAL HSP70 EXPRESSION LEVELS, (I) INDICATES INVASIVE AND (N) INDICATES NATIVE SPECIES; PANEL (A) HEMIPTERA- MRNA LEVELS * $P<0.5$, ERROR BAR REPRESENTS STANDARD DEVIATION; (B) TUNICATE- RELATIVE PROTEIN LEVELS, ERROR BAR REPRESENTS STANDARD ERROR; (C) MACROPHYTE- MRNA LEVELS, ERROR BAR REPRESENTS STANDARD ERROR. 

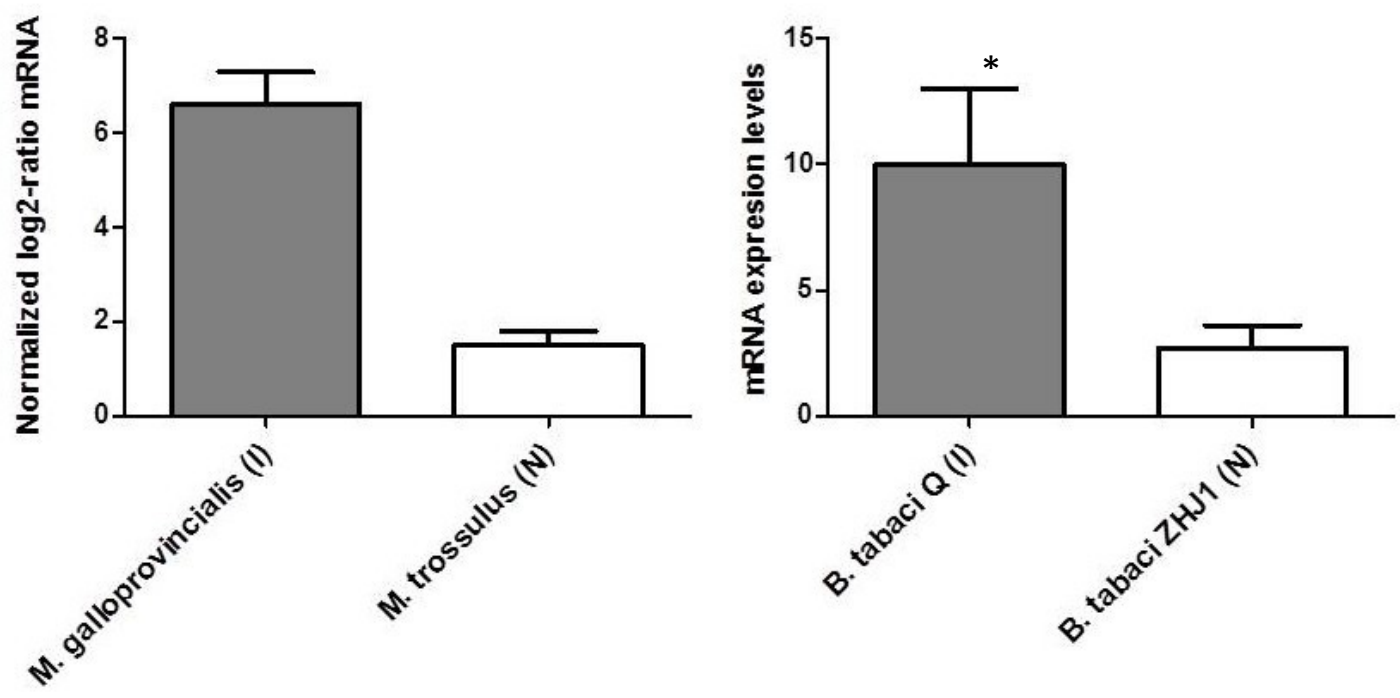

FIGURE 5.4 MAXIMAL HSP20 EXPRESSION LEVELS, (I) INDICATES INVASIVE AND (N) INDICATES NATIVE SPECIES; PANEL (A) BIVALVE- MRNA LEVELS ERROR BAR REPRESENTS STANDARD ERROR; (B) HEMIPTERA- MRNA LEVELS $P<0.01$, ERROR BAR REPRESENTS STANDARD DEVIATION.

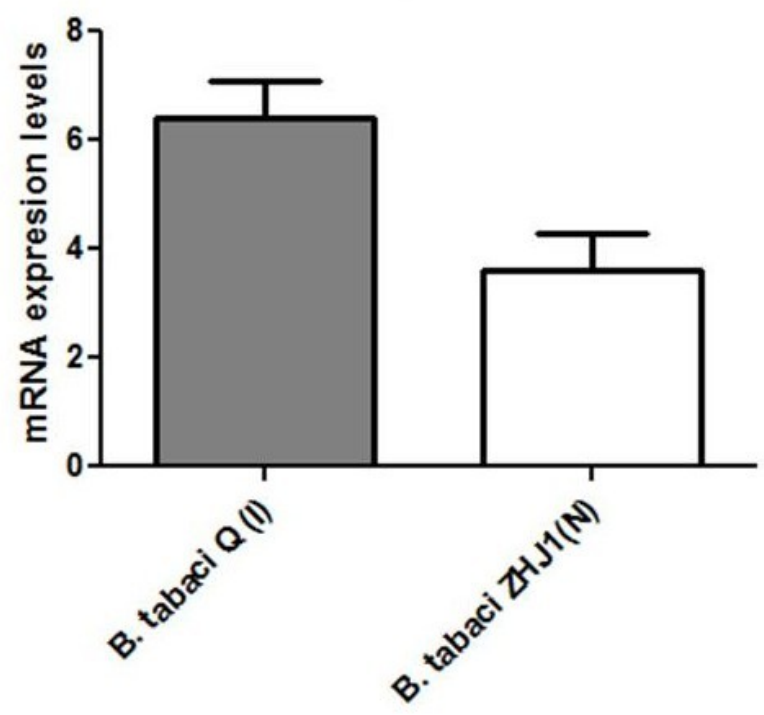

FIGURE 5.5 MAXIMAL HSP90 EXPRESSION LEVELS: HEMIPTERA, * $P<0.01$. (I) INDICATES INVASIVE AND (N) INDICATES NATIVE SPECIES ERROR BAR REPRESENTS STANDARD DEVIATION. 
Acclimation to warmer temperatures facilitates a greater range of thermal tolerance for invasives compared to native organisms Invasive organisms responded positively to acclimation, with acclimation to a warmer temperature always resulting in an increase in thermotolerance, characterized by a positive Acclimation Response Ratio-ARR (Fig 5.6).

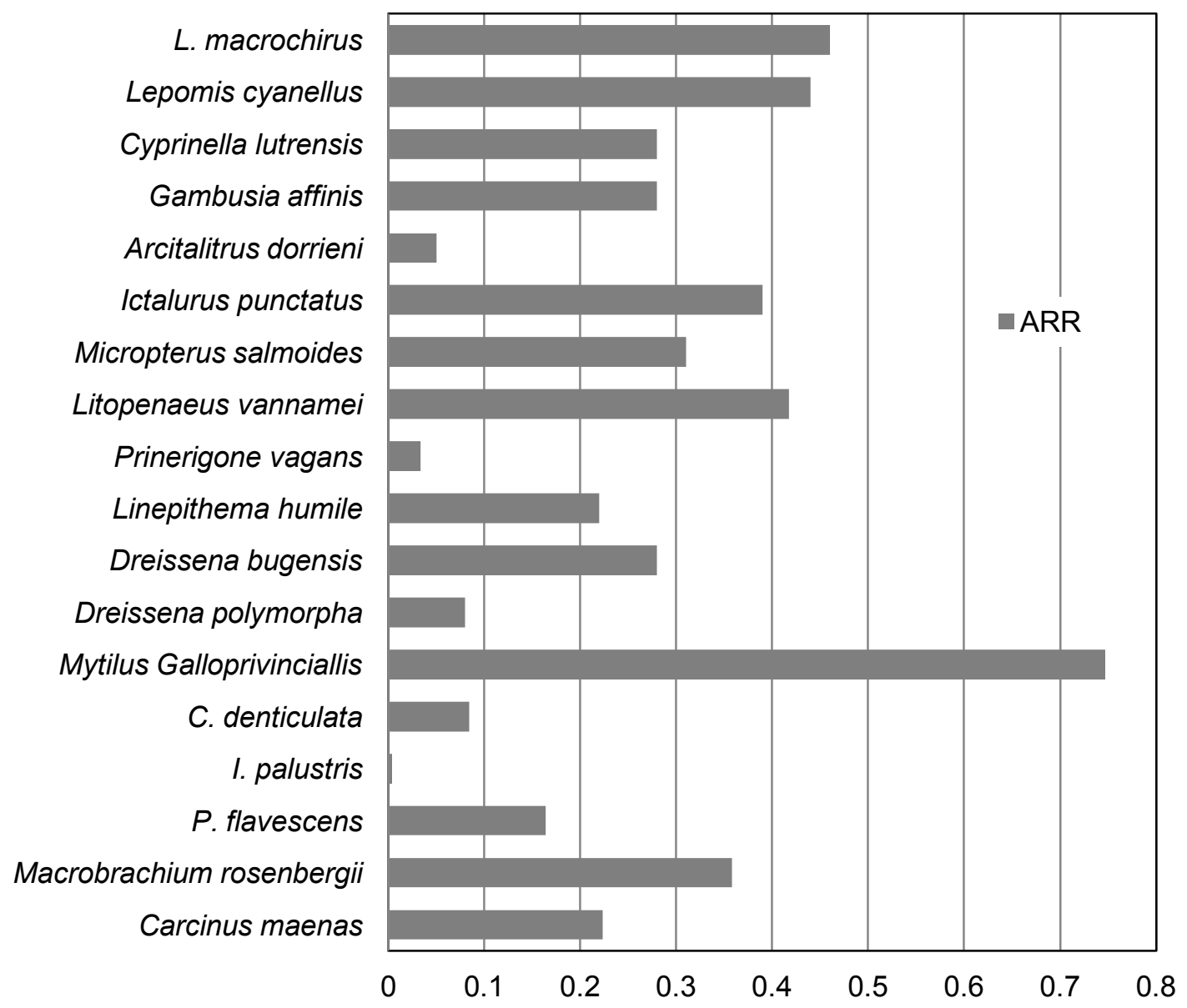

FIGURE 5.6 ACCLIMATION RESPONSE RATIO- ARR OF INVASIVE, TAXONOMICALLY DISTINCT ECTOTHERMS. 
The ARR for native species was negative in six cases, positive in 19 ones (Fig. $5.7)$.

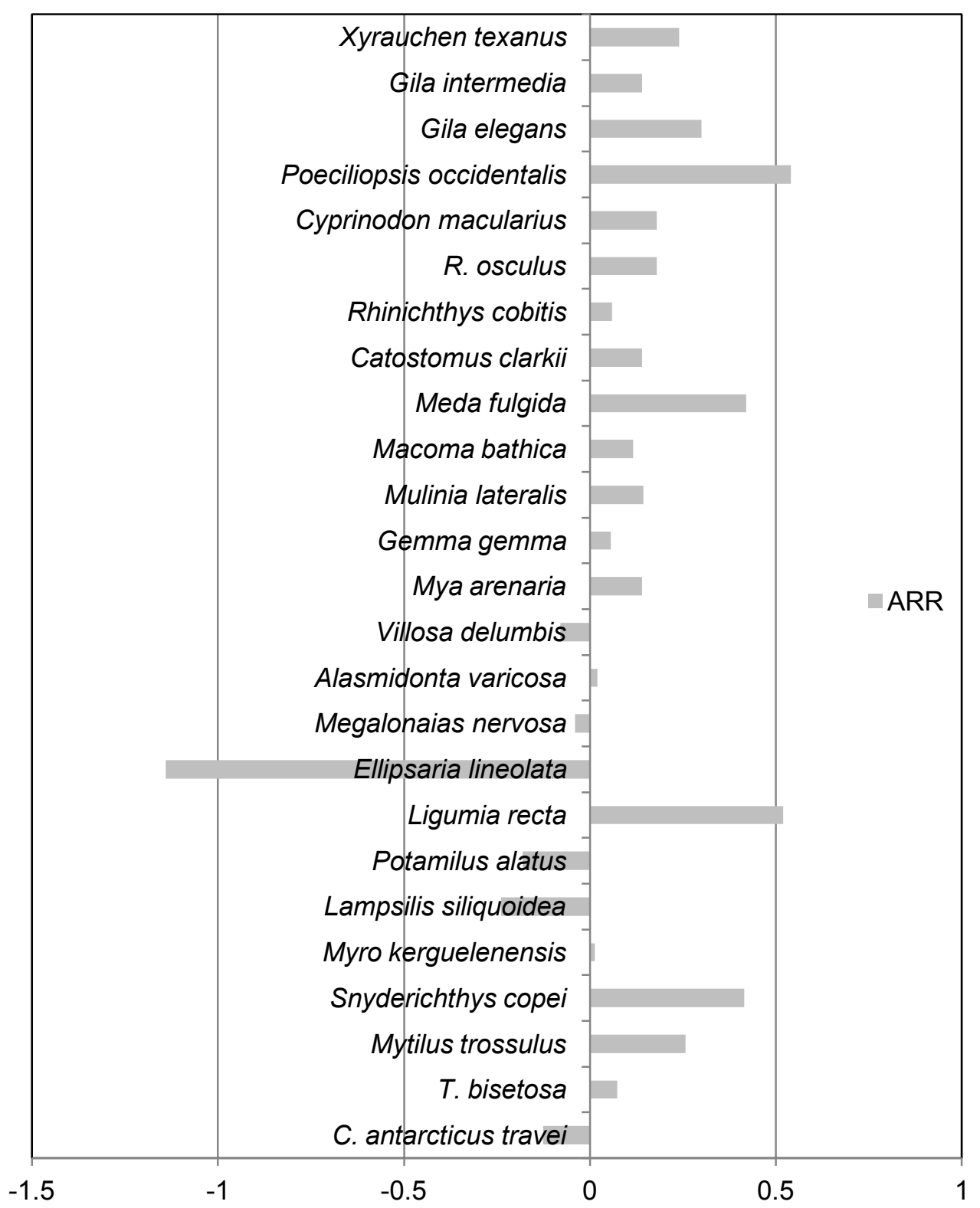

FIGURE 5.7 ACCLIMATION RESPONSE RATIO- ARR OF NATIVE, TAXONOMICALLY DISTINCT ECTOTHERMS.

Some native species exhibited negative ARR values, where acclimation to a higher temperature actually decreased the overall LT50 value (Table 5.3). 
A student's t-test comparing ARR values between native and invasive organisms found that they were significantly different $(p<0.04, t=2.13)$. The mean ARR and standard error for invasives and natives was $0.268 \pm 0.044$, $\mathrm{n}=18$, and $0.086 \pm 0.065, \mathrm{n}=24$, respectively. Some native taxonomic groups, e.g., bivalves, had many negative ARR values (Fig. 5.7). Conversely, invasive teleosts had ARR values that ranged between $0.28-0.46$, relatively higher than native teleosts, whose ARR values spanned from 0.06 to 0.44 (Fig. 5.6, Table $5.3)$.

\section{Discussion}

The results described above generally supported the hypotheses tested. The organisms in this study that successfully invaded new regions had several key physiologic features that potentially broaden their scope of tolerance. It may be that several of these mechanisms are working synergistically to aid invasives in overcoming abiotic constraints. Below I discuss how each of these mechanisms may be beneficial to invasive organisms, and how they are ecologically relevant to invasion success.

Range width is associated with broad physiological tolerance

There are several caveats to this approach, and the results should be viewed with caution. First, the rate of heat ramping was not consistent across all LT50 experiments, which is reasonable given the different physiologies of these different taxa. Second, the acclimation times varied between a week and a month. Variations in either of these variables can affect the final LT50 value, and 
there are insufficient data to use ramp rate and acclimation temperature as covariates in an analysis. Here, as with the other predictions, the intent is to start examining these mechanisms across taxa to identify the most promising avenues for future experimentation.

Across taxa, higher temperature tolerances were positively related to the breadth of geographic thermal occupation (fig. 5.1). Abiotic parameters serve as the first 'ecological filter' to invasion by non-natives (Olyarnik et al. 2009), and have been shown to be prohibitive to the establishment of invasive populations (Holway et al. 2002, Gerhardt and Collinge 2007). In most cases they can have a greater impact on invasion success than biotic interactions (Dethier and Hacker 2005). Furthermore, if invasives are capable of occupying large geographic areas, this may increase the number of source populations, further propelling secondary invasions. This in turn can increase the intensity and frequency of propagule pressure, thereby facilitating the potential for range expansion (Olyarnik et al. 2009, Pyšek et al. 2009).

The fundamental niche of a species is described as the combination of abiotic variables under which an organism can maintain a population without immigration. For invaders, these abiotic constraints are similar to those experienced in their ancestral ranges (Holt et al. 2005, Wiens and Graham 2005). For some invasive species, the abiotic niche they occupy in the recipient range is nearly identical to that occupied in their home range, as is the case for the invasive decapod Hemigrapsus sanguineus (Lohrer et al. 2000). Just the 
opposite is true for the invasive green crab, Carcinus maenas, as this invasive decapod has invaded variable and spatially disjunct abiotic habitats (Grosholz and Ruiz 1996); furthermore, environmental niche modeling has shown that Carcinus maenas' invasive range extends beyond what would be predicted by the native range alone. Nonetheless, when the ancestral environmental niche is broad, invasive organisms are capable of occupying a wide range of abiotic habitats, which is necessary for establishing viable, self sustaining populations.

Other studies examining thermal ranges (eurytolerance) and invasion success report results similar to the ones found in this study. For example, Moyle and Marchetti (2006) found that among invasive fishes in California, 66\% of successful invasions were found in fish that were extremely tolerant to high temperatures relative to native species. Also in the genus Mytilus, the invasive $M$. galloprovincialis exhibited a thermal niche reflective of its home range (broad thermal range, high LT50), which allowed this species to outcompete the native M. edulus, facilitating a cryptic invasion along the central California coast (Braby 2004, Braby and Somero 2006, Lockwood and Somero 2011).

An invasive organism's ancestral thermal niche, characterized by a discrete thermal range, modulates physiological performance on several biological levels. From a molecular standpoint, environmental temperature plays a key role in organismal performance due to its impacts on enzyme kinetics, enzyme-substrate affinity, cell membrane viscosity, and the pool of enzymes capable of operating across the thermal range experienced by an organism 
(Hochachka and Somero 2002). A loss of function in any of these molecular processes can affect organismal performance and in some cases lead to death.

The upper thermal extreme experienced in nature is correlated upper thermal tolerance threshold

For invasives, there was a clear relationship between the upper thermal temperature experienced in situ and the corresponding LT50 ( $R=0.7$, fig. 5.2). This study indicates that many invasive species had LT50 values that were similar to the upper thermal boundaries present in their ancestral range, and therefore function closer to their absolute thermal threshold (Stillman and Somero 2000, Somero 2005). This is especially true for intertidal ectotherms (Hochachka and Somero 2002, Jones et al. 2009). Although there was no statistical difference between LT50s for native and invasive ectotherms, this is perhaps an artefact of the uneven taxonomic comparison. Many of the native species used in this comparison are terrestrial ectotherms, whereas the majority of invasive species are derived from aquatic habitats. However, this result makes sense in that the majority of the native species used in the analysis are terrestrial arthropods, a group that has been shown to have high temperature tolerances due to the lack of thermal buffering that is present in aquatic environments (Pörtner 2002a). The results of the present analysis are similar to those found by Sorte et al. (Sorte et al. 2013), which found invasive species were less negatively affected by increases in environmental temperature (as a product of climate change) than native species in aquatic but not terrestrial environments. The 
results in both studies highlight the difference in upper lethal thermal limits between terrestrial and aquatic ectotherms, with only the aquatic invasive species tending to have a physiological advantage over native ones.

Pairwise analyses between closely related congeners found that invasives in general had higher lethal upper thermal thresholds than native species. For example, the invasive Mytilus galloprovincialis had an upper critical thermal temperature that was $3^{\circ} \mathrm{C}$ and $4^{\circ} \mathrm{C}$ higher than the native $M$. trossulus after acclimation to $14^{\circ} \mathrm{C}$ and $21^{\circ} \mathrm{C}$, respectively (Braby and Somero 2006). This was also the case for springtails from the sub-Antarctic Marion Islands: the invasive springtail Ceratophysella denticulata exhibited an LT50 of $35.4^{\circ} \mathrm{C}$ after acclimation to $0.1^{\circ} \mathrm{C}$ while the native Cryptopygus antarcticus travei had an LT50 at a lower temperature, $32.7^{\circ} \mathrm{C}$, after acclimation to $1.2^{\circ} \mathrm{C}$ (Slabber et al. 2007).

The narrow breadth of this analysis may in part contribute to the relatively minor differences found between native and invasive species LT50 values. It is possible that expanding this analysis to increase the overall sample size could emphasize the differences in upper thermal tolerance between native and invasive species.

Protein chaperone expression is greater in invasive than in native species

Although the statistical power of the pairwise comparisons of protein chaperone expression is low due to a small sample size, the expression levels between native and invasive organisms' revealed distinct differences in $T_{\text {on }}, T_{\max }$, and general expression patterns among three classes of heat shock proteins. 
Below I discuss the functional significance of each Hsp examined, and how variation in expression can affect organismal thermal tolerance, and thereby potentially affect invasion success.

The inducible isoform of Heat shock protein 70- Hsp70, is a molecular chaperone involved in refolding proteins that are denatured by environmental stressors like temperature, salinity, heavy metal contamination, UV damage, etc. (Lindquist 1986, Anthony 1999, Feder and Hofmann 1999). Much work evaluating the functional significance of this protein chaperone has lead to a broad understanding of its ecological relevance (Hochachka and Somero 2002, Somero 2002, 2005). In general, Hsp70 is not constitutively induced, so expression of this chaperone is thought to be a temporary or transitory stress response, aiming to returning a cell to homeostatic state (Hofmann and Somero 1996b, Feder and Hofmann 1999, Hochachka and Somero 2002). The expression of this gene product is thought to be integral to the setting of organismal thermotolerance limits, and has been used as a molecular indicator to compare the capacity of organisms to tolerate thermal stress (Tomanek and Somero 1999, Hochachka and Somero 2002, Somero 2002, 2005).

The results presented here illustrate that invasive organisms have greater maximal expression of Hsp70 than native species (Fig. 5.3) and that invasives had a higher Hsp70 $\mathrm{T}_{\text {on }}$ than natives (Table 5.2). For invasive bivalves and hemiptera, $\mathrm{T}_{\text {on }}$ was $2^{\circ} \mathrm{C}$ higher, than in natives, and for macrophytes it was $5^{\circ} \mathrm{C}$ higher for invasives versus natives (Table 5.2). Additionally, $T_{\max }$ was between 2 
and $15^{\circ} \mathrm{C}$ higher in invasive species than in native species. These results suggest that the invasives used in this pairwise analysis were more tolerant to heat stress in terms of both intensity and duration, as indicated by the higher $\mathrm{T}_{\text {on }}$ and $\mathrm{T}_{\max }$ temperatures. These results are congruent with work conducted with congeners of the native Tegula (marine intertidal snail), where those species that inhabited the upper intertidal, and consequently experienced a greater frequency and magnitude of heat stress, had a higher $T_{\text {on }}$ and $T_{\max }$ than the species than those occupying the mid to low intertidal (Tomanek and Somero 1999).

Hsp20 class has been shown to be responsive to both heat and osmotic stress (Lee et al. 2004, Gracey et al. 2008). The results presented here illustrate the role Hsp20 plays as a stress response in two distinct taxa, Hemiptera and Bivalve (Fig. 5.4). For both taxa, the invasive species had a greater maximal induction than the native congener (Fig. 5.4). Functionally, Hsp20 has been shown to inhibit apoptosis (Beere 2004) and from a mechanistic standpoint, Hsp20 has been found to act as a chaperone involved in the maintenance of cytoskeletal structure during bouts of environmental stress (Derham and Harding 1999). In addition, Hsp20 aims to ameliorate cytotoxic protein aggregation that occurs during heat stress (Horwitz 1992, Horwitz et al. 1992). For Hemiptera, $T_{\text {on }}$ was the same for both native and invasive species, $37^{\circ} \mathrm{C}$ (Table 5.2). $\mathrm{T}_{\max }$ for the invasive white fly was $41^{\circ} \mathrm{C}, 3^{\circ} \mathrm{C}$ higher than the native species. Research by Lockwood et al. (Lockwood et al. 2010) found that of all Hsp's available, only Hsp20 was upregulated in the warm adapted Mytilus galloprovincialis when 
compared to the native M. trossulus (Fig. 5.3) (Lockwood et al. 2010). Hence, upregulation of a single Hsp class protein may in part confer a higher organismal thermal tolerance, which was the case for $M$. galloprovincialis compared to $M$. trossulus (Braby and Somero 2006b, Lockwood and Somero 2011).

The role of Hsp90 as a molecular chaperone has been well documented (for review see Pratt 1998). Hsp90 functionally overlaps with Hsp70, and is also involved in cell signalling pathways, transcriptional regulation, and cell cycle control (Pratt 1998). Hsp90 is of particular importance due to its regulatory capacity over the cell cycle during bouts of environmental stress; Hsp90 is also an important mediator of continued cell cycle progression during bouts of thermal stress (McClellan et al. 2007). The ability of an organism to continue cell proliferation (mediated by the expression of Hsp90) under stressful conditions may give an invasive organism a physiological advantage over a native congener. In Hemiptera, Hsp90 expression was significantly greater in the invasive white fly than the native (Fig. 5.5). Like the Hsp20 expression in this taxonomic group, Hsp90 had the same $\mathrm{T}_{\text {on }}$, at $35^{\circ} \mathrm{C}$, but $\mathrm{T}_{\max }$ was $2^{\circ} \mathrm{C}$ higher for the invasive fly than for the native one (Table 5.2). Taken together, these results indicate that across taxonomically distinct groups, three classes of Hsp's have higher expression levels in the invasive species (Fig. 5.2, 5.3, 5.4). Furthermore, the studies reviewed showed that in every case, the invasive species had higher upper organismal thresholds (LT50), which correspond to the higher Hsp expressions. On average, invasive organisms had a $T_{\text {on }} 2.2^{\circ} \mathrm{C}$ 
$\left( \pm 1.7^{\circ} \mathrm{C}\right.$ standard deviation) higher than the native species used in this analysis. Furthermore, the invasives had a $\mathrm{T}_{\max } 6.8^{\circ} \mathrm{C}\left( \pm 5.2^{\circ} \mathrm{C}\right.$ standard deviation) higher than their native comparators.

Acclimation to warmer temperatures facilitates a greater range of thermal tolerance for invasive compared to native organisms

The ability of ectotherms to make adjustments to organismal thermal tolerance via acclimation/acclimatization has been widely explored, and is thought to allow species to persist across highly variable spatial-temporal thermal landscapes (Segal 1961, Hutchison and Maness 1979, Roberts et al. 1997, González et al. 2010). The ARR's for invasive species were higher than for native species examined, $0.268 \pm 0.044 \mathrm{~N}=18$ and $0.0859 \pm 0.0649 \mathrm{~N}=25$, $p=0.04$, respectively. The results presented here show a divergent response to acclimation. Invasive organisms under all acclimatory conditions had the ability to increase the scope of thermal tolerance after acclimation (Fig. 5.6). Native species on the other hand expressed a variety of responses to acclimation: some responded positively, like Mytilus trossulus, some responded negatively, as seen in Ellipsaria lineolata, and some made no adjustments to their organismal thermotolerance after acclimation, e.g., Alasmidonta varicose (Fig. 5.7). One possible reason that some native species responded with negative ARR values to higher acclimation (and a resulting lower LT50) is that the higher acclimation temperature was very near the upper thermal tolerance thresholds of those species, potentially preventing them from mounting a robust response to acute 
heat stress (Stillman and Somero 2000, Stillman 2003). Moreover, it has been noted that invasive species tend to be more tolerant to high temperatures, and native species are more tolerant to low temperatures when comparing the two across a recipient range (Braby and Somero 2006b, Slabber et al. 2007). Under this scenario, increases in environmental temperature via global climate change may be less problematic for or even benefit invasive species over native ones (Somero 2010, Somero 2012).

Acclimatory induced shifts in organismal thermal tolerance are underscored by a broad suite of molecular level processes such as a modification in the transcriptome (Fowler and Thomashow 2002), a variation in phase behaviour of the lipid bilayer (Hazel 1995), and a change in the specific isozyme used to conserve the kinetic activities of $K_{\mathrm{m}}$ and $K_{\text {cat }}$ such that substrate affinities and catalytic rates are maintained within an optimal range at physiological temperatures (Hochachka and Somero 2002, Fields et al. 2006). For the regionally endothermic bluefin tuna, Thunnus orientalis, acclimation to two different temperatures prompted a shift in the gene expression, upregulating genes involved in protein biosynthesis and genes responsible for both carbohydrate and lipid metabolism (Castilho et al. 2009). In Drosophila melanogaster, thermal acclimation has been shown to facilitate reordering of the glycerophospholipids within the lipid bilayer to help in maintaining membrane function at different temperatures (Overgaard et al. 2008). Fields et al. compared $K_{\mathrm{m}}$ and $K_{\text {cat }}$ values of Malate dehydrogenase orthologs between the invasive 
Mytilus galloprovincialis and the native Mytilus trossulus and discovered that $M$. trossulus had higher $K_{\mathrm{m}}^{\mathrm{NADH}}$ and $K_{\text {cat }}$ values of $\mathrm{cMDH}$, indicating lower substrate affinity and higher catalytic rate reflecting an adaptation to colder temperatures (Fields et al. 2006).

One potential mechanism that has been proposed to underlie the ability of a species to alter the scope of thermotolerance is referred to as the Brattstrom hypothesis (Brattstrom 1968). This theory posits that the acclimatory ability of an animal is related to the geographic range width they inhabit (Brattstrom 1968, Gaston et al. 2009). This was first identified in anurans, (Brattstrom 1968), and has since been identified in other taxa as well (Calosi et al. 2008, Calosi et al. 2010).

The ability of an invasive organism to acclimate and make physiological adjustments that maintain performance across a range of temperatures is integral to overcoming abiotic resistance within recipient environments. For invasive ectotherms, abiotic constraints pose a substantial barrier that must be surmounted in order for invasive populations to become established (Holway et al. 2002, Gerhardt and Collinge 2007). For cases when the physiological costs of acclimation inhibit performance, the invader would be at a physiological disadvantage when competing with a native species and likely would not establish. Therefore, the species that are at an advantage - or at least not at a disadvantage - are those that establish and are represented here.

\section{Conclusions}


This review addresses four major hypotheses that have been identified as physiologic correlates of invasion success. Each hypothesis was supported by the data, and the physiological traits examined were then considered within and ecological context, providing a mechanism for successful establishment of invasive species. These traits are not exclusive to invasion success, and it is likely that invasive species employ several of these physiologic traits to improve performance in new habitats. Although the taxonomic breadth of each analysis varied, this work highlighted that these physiological traits were utilized across a diverse array of taxa that also include a diverse set of habitat types. This review establishes a need for further investigations that include more representation from vertebrate and terrestrial species. Additionally, inquiries that look at how invasive organisms will respond to global climate change, and what their potential impacts might be to native species, communities, and ecosystems.

The work presented here has identified a methodological framework for addressing physiological differences between native and invasive species. This review has anecdotally provided only a correlative relationship between physiological traits and those invasive species that have successfully invaded new habitats. Although general trends have been highlighted by this paper, a direct assessment of native and invasive congeners from both aquatic and terrestrial habitats subjected to identical laboratory acclimation, heat ramping rate and upper lethal threshold protocols would further strengthen the support for these hypotheses. 


\section{CHAPTER SIX: BROAD CONCLUSIONS}

This dissertation has brought about advances in our understanding of the physiological traits that Carcinus maenas has utilized to establish viable populations along a $1300 \mathrm{~km}$ stretch of coast on the in the northeast Pacific. Our results suggest that divergence in the thermal physiology of two genetically similar populations of Carcinus maenas has occurred despite the short $(\sim 20 \mathrm{yr})$ timeline of invasion. First, the California population (CA) had higher thermal tolerance than the northern, British Columbia population $(\mathrm{BC})$ after cold $\left(6^{\circ} \mathrm{C}\right)$ and warm $\left(23^{\circ} \mathrm{C}\right)$ laboratory acclimation, as determined by the CTmax experiment. Second, the CA cold-acclimated group was able to mount a strong Hsp70 response, stronger than the cold-acclimated $B C$ one, in response to heat ramping. Third, in the isolated tissue experiment, the CA group had greater expression across all treatment temperatures at the $2 \mathrm{hr}$ time point. Taken together, these results suggest phenotypic variation in thermotolerance.

Range expansion of Carcinus maenas has been primarily northward into seasonally cooler waters, implicating cold stress as an environmental variable that has the potential to shape further range expansion. Cold tolerance capacity was determined in the laboratory by holding crabs sampled from Vancouver Island, British Columbia, Canada to an overwintering thermal profile generate from Sitka, Alaska. Crabs experienced high survivorship, indicating that adult crabs are thermally capable of existing outside their current northern range limits. In addition to testing whole organism cold tolerance, we measured levels of 
several candidate proteins that have been shown to regulate cellular function in the face of variations in environmental temperature with the goal of maintaining cellular homeostasis. For this purpose, intraspecific comparisons using animal sampled from the northern and southern part of their range were used to identify differences in variations in expression of candidate proteins that have been shown to alter expression during bouts of cold exposure in other aquatic ectotherms. We measure the relative levels of cyclin D1 (cell-cycle modulator) and Hsp70 (protein chaperone) in response to cold stress/shock. Only the BC population significantly down regulated cyclin D1 after cold shock, suggesting that this population has initiated one aspect of the cellular stress response when compared to the CA populations. The variations in expression that were detected may provide some insight into the mechanisms that have made possible the northward expansion of this non-native species.

An observable difference in body size has been identified, with a clinal gradient in carapace width- CW, reflecting the thermal gradient present on the west coast of North America. Crabs sampled acrossed its range show a size, temperature relationship, $\mathrm{R}=0.77$, with the larger morphology hailing from the northern portion of the range, and the smaller crabs from sites in California. A literature review was conducted of $\mathrm{CW}$ across latitude for populations sampled from their native range, in an effort to identify a size and temperature correlation. Again, there was found to be a correlation between these two variables, $R=0.77$ 
in the ancestral range, with the larger eco-morph being found in Northern Europe.

The invasion of the European green crab has provided us with an eloquent study system to answer many relevant questions that relate to cellular and organismal physiology, biogeography, and ecology of invasive species. These investigations have yielded several hypotheses regarding physiologic mechanisms that have facilitated invasion success, and were generally supported across a wide array of taxa. 


\section{CHAPTER SEVEN: GLOBAL CHANGE BIOLOGY: MODELING THE PROCESS OF OCEAN ACIDIFICATION AS A FRAMEWORK FOR UNDERSTANDING THE EFFECTS OF GLOBAL CLIMATE CHANGE ON MARINE ORGANISMS}

\section{Introduction}

Human activities are the primary driving force behind global climate change, as increases anthropogenic atmospheric $\mathrm{CO} 2$ are forecast to drastically increase ocean warming and ocean acidity by the end of this century (Meehl et al. 2007). Ocean acidification- OA is the process of $\mathrm{CO} 2$ absorption by the world's oceans, thereby reducing the $\mathrm{pH}$ of seawater and carbonate ion concentrations. Changes in ocean acidity particularly affects those organisms with calcium carbonate, $\mathrm{CaCO}_{3}$ shells and skeletons, and are considered to be the first taxonomic groups that will be subject to experience the deleterious effects of environmental acidity due to the lowered saturation state of $\mathrm{CaCO}_{3}$ under acidified conditions (Fabry et al. 2008, Aronson et al. 2009). Already, experimental work has found that OA negatively impacts many species of marine calcifiers from all eco-regions, they include coccolithophores, corals, foraminifera, echinoderms, crustaceans and molluscs (NRC 2011). Furthermore, the World Health Organization has stated that global climate change has already led to " 5 million cases of illness and more than 150,000 deaths every year" (Patz et al. 2005), underscoring the need to broaden public awareness about the consequences of global climate change. 
The youth of today are most likely to suffer the negative effects of global climate change. In order for the citizens of tomorrow to alter the present trajectory of our changing environment, they must bring to task global economies by imploring our leaders to implement sustainable management practices and make informed policy choices regarding the health of our planet. It is vital to begin to create a connection between student's general awareness of this problem, and the actual consequences facing our natural world. Research has shown that understanding what global climate change is doesn't necessarily lead to understanding the consequences of it (Boyes and Stanisstreet 1993). Our perceptions of these sorts of issues often lack an experiential component- if we can't 'see' the negative effects of climate change, it is more difficult to understand what the impacts are.

Human response to visual perception of an environment can be categorized in several ways: effective- relating to feelings, emotions and attitudes; behavioral- behavioral changes of the observer; and cognitive- relating to knowledge and understanding (Zube et al. 1982). Cognitive understanding through visualization and visceral experience can communicate messages quickly and effectively and instantly trigger reactions and emotions that persist over time and influence people's decision making (Zajonc 1984, Slovic et al. 2007). Furthermore, visually acquired information has been found to be more cognitively integrated over written or verbally acquired information (Tufte 1991). Given how information that's perceived visually is more likely to be cognitively 
understood and can alter decision making, providing students with curriculum that simply illustrates the effects of global climate change has the potential to influences their perceptions and choices as they move into adulthood.

\section{Ocean Acidification-OA}

Currently, the marine environment is undergoing a rapid state of change as a result of human activity (Meehl et al. 2007), as drastic increases in atmospheric concentrations of $\mathrm{CO}_{2}$ are being absorbed by the world's oceans (Sabine et al. 2004). Between 1751 and 1994, surface ocean pH is estimated to have decreased from roughly 8.25 to 8.14 (Jacobson 2005), representing a $\sim 30 \%$ increase in hydrogen ion concentrations. A reduction in oceanic $\mathrm{pH}$ heavily impacts marine organisms that produce shells and skeletons through the process of calcification, which involves the precipitation of dissolved ions into $\mathrm{CaCO}_{3}$, referred to as calcium carbonate (Fabry et al. 2008). Through the process of biomineralization, calcium carbonate is deposited within marine calcifiers, and provides a physical structure for soft tissue to adhere to, much the same way bones provide structure for vertebrate organisms. When $\mathrm{CO}_{2}$ is absorbed by the ocean, resulting in decreased $\mathrm{pH}$, the saturation state of $\mathrm{CaCO}_{3}$ is reduced, driving the dissolution of calcium carbonate within marine calcifiers (for review see Fabrey et al. 2008). 


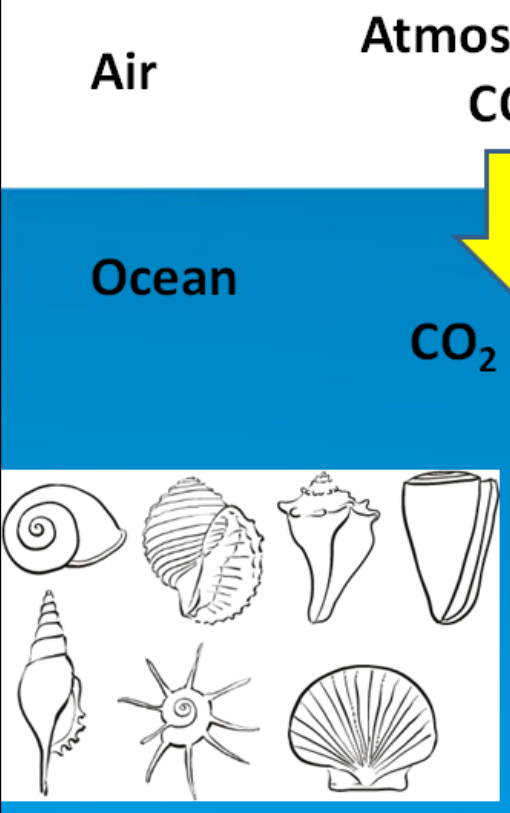

Calcium carbonate

\section{Atmospheric}

$\mathrm{CO}_{2}$

$\mathrm{CO}_{2}+\mathrm{H}_{2} \mathrm{O} \longrightarrow \mathrm{H}_{2} \mathrm{CO}_{3}$ 1. Carbonic acid<smiles>C1=CCCC1</smiles>

\section{$\mathrm{H}^{+}+\mathrm{HCO}_{3}^{-}$2. Bicarbonate}

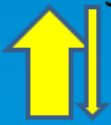

$\mathrm{H}^{+}+\mathrm{HCO}_{3}^{2-}$ 3. Carbonate

Net negative

calcification

7. 1 CALCIFICATION REACTION IN THE SEA WATER. AN INCREASE IN HYDROGEN $(\mathrm{H}+)$ IONS ALTERS THE EQUILIBRIUM REACTION, LEADING TO A SHIFT TOWARDS BICARBONATE. THIS IS BECAUSE THE EXCESS HYDROGEN IONS COMBINE WITH CARBONATE TO FORM BICARBONATE. CARBONIC ACID IS LESS STABLE THAN BICARBONATE IN SEA WATER, SO THAT REACTION IS ALSO SHIFTED TOWARDS BICARBONATE.

Over the last decade, there have been a plethora of studies exploring the effects of ocean acidification on marine calcifiers that represent many trophic levels of the food web (Gattuso et al. 1998, Gattuso et al. 1999, Fabry et al. 2008, Clark et al. 2009, Comeau et al. 2010, Donnell et al. 2010, Yu et al. 2011), underscoring the potential deleterious effects OA can have on overall ecosystem function (Fabry et al. 2008).

An illustrative example of the direct effects of OA on an economically important bivalve species was identified on the Oregon coast in Netarts Bay. 
Researchers from Oregon State University directly linked increases in OA to the decline of oyster seed production at Whiskey Creek Shellfish Hatchery. They found that as OA increased, growth was reduced and mortality increased (Barton et al. 2012), reducing the economic viability of this aquaculture product. Furthermore, the mariculture of oysters on the west coast generates roughly 100 million dollars in gross sales annually, and is an important component of local commerce for small coastal economies.

\section{Project-based curriculum}

The two in class activities presented here demonstrate the process of ocean acidification and its consequences to marine life. Additionally, these projects demonstrate how hypothesis testing can be accomplished with hands on data collection via experimentation and analysis. These lessons can be utilized to support education standards in Earth science, biology, environmental science, marine science, or chemistry curricula.

While investigations into the biological effects of $O A$ often require very elaborate experimental set-ups, the basic underlying carbonate chemistry that is highlighted in the following experiments can be easily achieved in a classroom setting using household materials. These activities are intended to be used for grades levels 6-9. Below are two labs, one that can be done within an hour, and a second that can up to 6 weeks. The following lists the materials and procedures, as well as the intended cognitive understanding of these experiments. 


\section{Experiment 1- duration: 1 hour}

Briefly, this experiment is intended to illustrate how an acidic environment can affect an animal's calcium carbonate structure. Chalk is made of limestone, a byproduct of the gradual accumulation of minute calcium carbonate plates shed from coccolithophores over evolutionary time, and represents the "marine organism" in this experiment. To represent the "acidic ocean", a number of household items can be used, including lemon juice, soda, or vinegar. These three solutions vary slightly in their relative acidity, and all can be used to compare the differing effects that variations in $\mathrm{pH}$ can have on the dissolution of the chalk. Scaffolding for this inquiry would include an introduction to the $\mathrm{pH}$ scale and how concentrations $\mathrm{H}^{+}$influence relative $\mathrm{pH}$.

\section{Chalk-Acid Lab}

\section{Goals}

In this activity you will learn about the effect of ocean acidification on marine calcifiers. The goal of this activity is to investigate how changes in the external environment affect organisms.

\section{Introduction:}

What are 3 organisms that live in the ocean with a calcium carbonate shell or skeleton? Which solution $(1,2$, or 3$)$ do you think will cause the greatest degree of change in the chalk? Answer this in your hypothesis. Remember to explain why you think so.

\section{State the hypothesis:}




\section{Materials:}

4 beakers lemon juice, soda, milk 3 weigh boats

3 pieces of chalk Graduated cylinder $\quad$ Forceps

Paper towel Vernier $\mathrm{pH}$ meter Timer

Bottle of rinse water Scale $(\mathrm{g})$

\section{Procedure:}

Label your beakers 1, 2, 3 and Rinse. Use the graduated cylinder to measure 50 $\mathrm{ml}$ of one of the three solutions and then pour it into the corresponding beaker (ex. pour $50 \mathrm{ml}$ of solution 1 into beaker. Then rinse the graduated cylinder using the bottle of rise water and pour the water into the cylinder labeled rinse. Repeat this step for all 3 solutions. Use the $\mathrm{pH}$ meter to determine the starting $\mathrm{pH}$ of each solution and record in the data table. The $\mathrm{pH}$ meter must stay in the solution for awhile to get an accurate reading, so have some members of your group proceed to step 4. Remember: rinse the probe between each measurement and make sure that the water $\mathrm{pH}$ is near $7-8$, if it is not, ask an instructor to help re-calibrate your probe Label your weigh boats 1,2 , and 3 . Place one of the weigh boats on the scale, tare the scale, and place one of the pieces of chalk on it. Record the chalks mass (grams) in the data table, and then repeat the process with the other weigh boats and chalk. Once the $\mathrm{pH}$ of the solutions and the mass of the chalk pieces are recorded set your timer for 5 minutes. When you start the timer, drop the chalk pieces in to the corresponding 
beaker (ex. chalk in weigh boat 1 goes in beaker 1). Be sure to drop in all the chalk pieces at the same time! Gently swirl each solution frequently during the 5 minutes. When the timer beeps, use the forceps to remove the chalk pieces from the solutions. Blot dry the chalk using a paper towel and weight each piece like you did in step 4. Be sure to put each chalk in its appropriate weigh boat so they don't get mixed up. Record the mass (grams) in the table. Reset the timer for 5 minutes and place the chalk pieces back in the proper beakers. When the timer beeps remove and weigh the chalk (just like you did in step 7), and record the mass after 10 minutes a table. Set the timer for 5 minutes again, and weight the chalk when the timer beeps. At this point, Each piece of chalk should have been in its solution for 15 minutes in total and you should have 4 measurements of mass (Initial, 5 minutes, 10 minutes, 15 minutes) for all 3 pieces of chalk. Use the $\mathrm{pH}$ meter to determine the final $\mathrm{pH}$ of each solution. Record this information in the data table.

\begin{tabular}{|l|l|l|l|l|l|l|l|}
\hline Solution & Initial & Chalk & Chalk & Chalk & Chalk & Chalk & Chalk \\
& Solution & mass & mass & mass & mass & mass & mass \\
& $\mathrm{pH}$ & in & in & in & in & in & in \\
& & grams & grams & grams & grams & grams & grams \\
& (initial) & (initial) & (initial) & (initial) & (initial) & (initial) \\
\hline 1 & & & & & & & \\
\hline 2 & & & & & & & \\
\hline
\end{tabular}




\begin{tabular}{|l|l|l|l|l|l|l|l|}
\hline $\mathbf{3}$ & & & & & & & \\
\hline
\end{tabular}

\section{Results:}

Make 2 graphs showing your results - one showing change in chalk mass over time and one showing change in $\mathrm{pH}$ for each solution

\section{Analysis}

Describe your observations. Did your results support your original hypothesis? Did the results surprise you? Why? How does this model illustrate the effect of ocean acidification on marine calcifiers?

\section{Conclusion}

Reflect on the procedure and note any errors. What changes would you make in the procedure for someone else doing this lab? What could be changed to look at more effects in the future?

\section{Inquiry to understanding}

The goal of this activity is to create a cognitive visual link between ocean acidification and its effects on marine calcifiers. After completing this experiment, students will be able to visually see the dissolution of the chalk over time, and can quantitatively characterize the change in mass as well. Because chalk is actually derived from marine organism fossils, students can logically associate the use of chalk to represent marine calcifiers in this experiment. The solutions used to represent an "acidic ocean" can also provide an additional cognitive reinforcement. Students can taste the lemon juice and 'feel' what an acidic 
solution tastes like. Also, when discussing the acidic solutions used in this inquiry, the question can be asked "what gas makes soda fizzy?" Most students know the answer is carbon dioxide. Measuring the $\mathrm{pH}$ of each solution before the initiation of the experiment can visually illustrate that liquids with carbon dioxide in them are acidic. With this knowledge, students can again cognitively link the absorption of $\mathrm{CO}_{2}$ to ocean acidification.

Although this activity is straightforward, it does introduce a degree of learning disequilibrium, or cognitive conflict, where a student holds two contradictory views and understands that both cannot be true (Piaget 1932, 1936, 1957). The chalk in this experiment is dry upon initial weighing. After the chalk is initially placed in the solution, and then is retrieved and weighed, it weighs more than the first measurement due to the absorption of liquid into the porous chalk. The student believes that the chalk should decrease in weight after exposure to the acidic solution. When this does not occur, the student must assimilate the information and then make accommodations, or alter their knowledge base to fit in this new piece of information (Piaget 1936, 1957). Once the new information is understood, a state of equilibrium occurs, meaning a student has altered its thought process to incorporate the new piece of information (Piaget 1936, 1957). The cognitive disequilibrium in this case is that the chalk doesn't weigh less after it is first exposed to the solution. However, after an initial increase in mass (due liquid absorption), the chalk eventually loses mass over time during exposure to the acidic liquid. 


\section{Experiment 2- duration: 6 weeks}

This activity is a more realistic representation of the affects of OA because it utilizes actual calcium carbonate shells from marine calcifiers. Again, the "acidic ocean" in this experiment can be created from several household items, including vinegar, lemon juice, or another acidic compound. The duration of this experiment can be augmented, but a minimum of 4 weeks is necessary to visually see the changes in size and mass of the shells.

\section{Mimicking the process of ocean acidification:}

\section{The effect of an acidic solution on calcium carbonate shells}

\section{Goals}

In this activity you will directly test the effect of an acidic solution, "ocean acidification" on marine calcifiers. The goal of this activity is to investigate how changes in the external environment affect marine organisms with a calcium carbonate shells and skeletons.

\section{State the hypothesis:}

\section{Materials and methods}

Calcium carbonate shells

Scale set to grams

1 gallon of vinegar
5 gallon bucket

aquarium aerator with air stone

$\mathrm{pH}$ probe

Collect a various assortment of calcium carbonate shells from marine organisms, dry them thoroughly, and let them sit out overnight. Weigh each shell and record 
this mass as the initial mass at the beginning of the experiment. It is important to be able to identify each shell visually through the course of this activity; tracing the outline of each shell in a lab notebook can help identify each shell. In a 5 gallon bucket, place one gallon of white vinegar and one gallon of tap water, measure the $\mathrm{pH}$ and record it (should be between 4-6 pH). Place the aerator bubbler in the 5 gallon bucket and turn it on. It is important to have continued water/vinegar flow over the shells so that the $\mathrm{CaCO}_{3}$ continues to react with the acid over the duration of the experiment. Deposit the shells in the bucket, and visually describe what you see. Some shells will start to "bubble" as shell dissolution immediately starts when the shells are placed in the bucket. The chemical equation for the active dissolution of shells is $\mathrm{CaCO}_{3}=>\mathrm{Ca}^{2+}+\mathrm{CO}_{3}{ }^{2-}$ (steps 3-4, Figure 7.1).

After a week of submersion, remove the shells from the bucket, hand dry them with a towel and set them out overnight to dry. After drying for 24 hours, weigh each shell and record the mass in grams in your lab notebook. Note any visual changes to the shells, do they look lighter in color? Do they look as though they were bleached? Before placing the shells back in the bucket record the $\mathrm{pH}$ of the vinegar water. Did the $\mathrm{pH}$ change from your original $\mathrm{pH}$ measurement at the start of this experiment? The $\mathrm{pH}$ of the vinegar water has probably changed, so replace it with new vinegar water set at the same concentration that was used at the start of the experiment. Verify the $\mathrm{pH}$ of your replacement solution with a $\mathrm{pH}$ 
probe. Put the shells back in the bucket and make sure the aerator is working properly.

Repeat the above steps for at least 4 weeks.

\begin{tabular}{|l|l|l|l|l|l|}
\hline Shell & Initial & Week 1 & Week 2 & Week 3 & Week 4 \\
number & mass (g) & mass (g) & mass (g) & mass (g) & mass (g) \\
\hline 1 & & & & & \\
\hline 2 & & & & & \\
\hline 3 & & & & & \\
\hline 4 & & & & & \\
\hline 5 & & & & & \\
\hline 6 & & & & & \\
\hline 7 & & & & & \\
\hline
\end{tabular}

\section{Results}

Make a line graph of your results. What shell lost the most mass over the course of the experiment? Did each shell lose the same amount of mass each week?

\section{Analysis}

Describe your observations. Did your results support your original hypothesis? Did the results surprise you? Why? How does this model illustrate the effect of ocean acidification on marine calcifiers?

\section{Conclusion}


Reflect on the procedure and note any errors. What changes would you make in the procedure for someone else doing this lab?

\section{Inquiry to understanding}

Research confirms the need for new models of climate change education (Moser and Dilling 2004). This activity provides a model that visually demonstrates how an acidified solution reacts with calcium carbonate biostructures that result in active dissolution of those structures via a chemical reaction (steps 2-4, Figure 7.1). Students who participate in this lab will be able to visually recognize that ocean acidification is a threat to the global oceans, which can lead to behavioral augmentation that reduces the human impacts of global climate change because students now understand the significance of the problem (Mohai 1985).

\section{Conclusion}

It is imperative that the global citizenry are informed with regards to the causes and consequences of global climate change, and make knowledge based decisions with respect to the future of our planet. In particular, laboratory experience is necessary for understanding science, as verbal and written forms of communication do not adequately translate the scientific process (Singer et al. 2006). The inquiries presented here are an inexpensive, easy to understand alternative to simply lecturing about global climate change. Global climate change education has the potential to alter the future course of environmental policy and decision making, potentially impacting the future of our planet. 


\section{REFERENCES}

Addo-Bediako, A., S. L. Chown, and K. J. Gaston. 2000. Thermal tolerance, climatic variability and latitude. Proceedings of the Royal Society of London. Series B: Biological Sciences 267:739-745.

Ali, K. S., L. Dorgai, M. Ábrahám, and E. Hermesz. 2003. Tissue- and stressorspecific differential expression of two hsc70 genes in carp. Biochemical and Biophysical Research Communications 307:503-509.

Ameyaw-Akumfi, C. and R. Hughes. 1987. Behaviour of Carcinus maenas feeding on large Mytilus edulis. How do they assess the optimal diet. Marine Ecology Progress Series 38:213-216.

Ameyaw-Akumfi, C. and E. Naylor. 1987. Spontaneous and induced components of salinity preference behaviour in Carcinus maenas. Marine Ecology Progress Series 37:153-158.

Angilletta, M. J. and A. E. Dunham. 2003. The temperature-size rule in ectotherms: simple evolutionary explanations may not be general. The American Naturalist 162:332-342.

Anthony, L. F. 1999. Chaperone-mediated protein folding. Physiological Reviews 79:425-449.

Aronson, R. B., R. M. Moody, L. C. Ivany, D. B. Blake, J. E. Werner, and A. Glass. 2009. Climate Change and Trophic Response of the Antarctic Bottom Fauna. PLoS ONE 4:e4385.

Ashton, G. V., K. J. Willis, M. T. Burrows, and E. J. Cook. 2007. Environmental tolerance of Caprella mutica: Implications for its distribution as a marine non-native species. Marine Environmental Research 64:305-312.

Ashton, K. G. 2004. Sensitivity of Intraspecific Latitudinal Clines of Body Size for Tetrapods to Sampling, Latitude and Body Size. Integrative and Comparative Biology 44:403-412.

Atkinson, D. 1994. Temperature and Organism Size-A Biological Law for Ectotherms? Pages 1-58 in M. Begon and A. H. Fitter, editors. Advances in Ecological Research. Academic Press.

Atkinson, D. 1996. Ectotherm life-history responses to developmental temperature. Animals and temperature: Phenotypic and evolutionary adaptation:183-204.

Atkinson, D., B. J. Ciotti, and D. J. S. Montagnes. 2003. Protists decrease in size linearly with temperature: ca. $2.5 \%{ }^{\circ} \mathrm{C}-1$. Proceedings of the Royal Society of London. Series B: Biological Sciences 270:2605-2611.

Atkinson, D. and R. M. Sibly. 1997. Why are organisms usually bigger in colder environments? Making sense of a life history puzzle. Trends in Ecology and Evolution 12:235-239.

Audet, D., G. Miron, and M. Moriyasu. 2008. Biological characteristics of a newly established green crab (Carcinus maenas) population in the southern Gulf of St. Lawrence, Canada. Journal of Shellfish Research 27:427+. 
Baker, A. C., C. J. Starger, T. R. McClanahan, and P. W. Glynn. 2004. Coral reefs: corals' adaptive response to climate change. Nature 430:741-741.

Baldridge, A. and L. Smith. 2008. Temperature constraints on phenotypic plasticity explain biogeographic patterns in predator trophic morphology. Marine Ecology Progress Series 365:25-34.

Baltz, D. 1993. Invasion resistance to introduced species by a native assemblege of stream fishes Ecological Applications 3:246-255.

Barth, J. and R. Smith. 1998. The coastal ocean off Oregon and Northern California during the 1997-8 El Nino, Part 3: a Lagrangian view. Transactions of the American Geophysical Union 79:F485.

Barton, A., B. Hales, G. G. Waldbusser, C. Langdon, and R. A. Feely. 2012. The Pacific oyster, Crassostrea gigas, shows negative correlation to naturally elevated carbon dioxide levels: Implications for near-term ocean acidification effects.

http://scholarsarchive.library.oregonstate.edu/xmlui/handle/1957/31837.

Beere, H. M. 2004. 'The stress of dying': the role of heat shock proteins in the regulation of apoptosis. Journal of Cell Science 117:2641-2651.

Behrens-Yamada, S., B. Dumbauld, A. Kalin, C. Hunt, R. Figlar-Barnes, and A. Randall. 2005. Growth and persistence of a recent invader Carcinus maenas in estuaries of the northeastern Pacific. Biological Invasions 7:309-321.

Behrens-Yamada, S. and C. Hunt. 2000. The arrival and spread of the European green crab, Carcinus maenas in the Pacific Northwest. Dreissena! 11:1-7.

Behrens Yamada, S. and G. E. Gillespie. 2008. Will the European green crab (Carcinus maenas) persist in the Pacific Northwest? ICES Journal of Marine Science: Journal du Conseil 65:725-729.

Berrill, M. 1982. The life cycle of the Green crab Carcinus maenas at the northern end of Its range. Journal of Crustacean Biology 2:31-39.

Billman, E. J., E. J. Wagner, R. E. Arndt, and E. VanDyke. 2008. Optimal temperatures for growth and upper thermal tolerance of juvenile northern leatherside chub. Western North American Naturalist 68:463-474.

Bin, B. and X. Wei-Hua. 2011. Identification of gene expression changes associated with the initiation of diapause in the brain of the cotton bollworm, Helicoverpa armigera. BMC Genomics 12:224-237.

Blackburn, T. M., K. J. Gaston, and N. Loder. 1999. Geographic gradients in body size: A clarification of Bergmann's Rule. Diversity and Distributions 5:165-174.

Blueweiss, L. F., H. Kudzma, V. Nakashima, D. Peters, R. Sams, S. 1978. Relationships between body size and some life history parameters. Oecologia 37:257-272.

Bochdanovits, Z. and G. de Jong. 2003. Temperature dependent larval resource allocation shaping adult body size in Drosophila melanogaster. Journal of Evolutionary Biology 16:1159-1167. 
Bonner, J. T. 1988. The evolution of complexity by means of natural selection. Princeton University Press, Princeton, N.J.

Boyes, E. and M. Stanisstreet. 1993. The 'greenhouse effect': children's perceptions of causes, consequences and cures. International Journal of science education 15:531-552.

Braby, C. 2004. Physiological ecology of native and invasive blue mussels (genus: Mytilus) in central California. Stanford, Palo Alto.

Braby, C. E. and G. N. Somero. 2006a. Ecological gradients and relative abundance of native (Mytilus trossulus) and invasive (Mytilus galloprovincialis) blue mussels in the California hybrid zone. Marine Biology 148:1249-1262.

Braby, C. E. and G. N. Somero. 2006b. Following the heart: temperature and salinity effects on heart rate in native and invasive species of blue mussels (genus Mytilus). Journal of Experimental Biology 209:2554-2566.

Brattstrom, B. H. 1968. Thermal acclimation in anuran amphibians as a function of latitude and altitude. Comparative Biochemistry and Physiology 24:93111.

Broekhuysen, G. J. 1936. On development, growth, and distribution of Carcinus maenas. Archives Neerlandaises de Zoologie 2:257-339.

Brown, J. H. and B. A. Maurer. 1986. Body size, ecological dominance and Cope's rule. Nature Nature 324:248-250.

Brown, J. H., G. C. Stevens, and D. M. Kaufman. 1996. The geographic range: size, shape, boundaries, and internal structure. Annual Review of Ecology and Systematics 27:597-623.

Buckley, B. 2011. Acute heat stress and thermal acclimation induce CCAAT/enhancer-binding protein delta in the goby Gillichthys mirabilis. Journal of Comparative Physiology B: Biochemical, Systemic, and Environmental Physiology 181:773-780.

Buckley, B. A. and G. E. Hofmann. 2002. Thermal acclimation changes DNAbinding activity of heat shock factor 1 (HSF1) in the goby Gillichthys mirabilis: implications for plasticity in the heat-shock response in natural populations. Journal of Experimental Biology 205:3231-3240.

Buckley, B. A., M.-E. Owen, and G. E. Hofmann. 2001. Adjusting the thermostat: the threshold induction temperature for the heat-shock response in intertidal mussels (genus Mytilus) changes as a function of thermal history. Journal of Experimental Biology 204:3571-3579.

Burmeister, A. and B. Sainte-Marie. 2010. Pattern and causes of a temperaturedependent gradient of size at terminal moult in snow crab, Chionoecetes opilio along West Greenland. Polar Biology 33:775-788.

Byers, J. E., W. G. McDowell, S. R. Dodd, R. S. Haynie, L. M. Pintor, and S. B. Wilde. 2013. Climate and $\mathrm{pH}$ predict the potential range of the invasive Apple Snail Pomacea insularum in the Southeastern United States. PLoS ONE 8:e56812. 
Callaway, R. M. and W. M. Ridenour. 2004. Novel weapons: Invasive success and the evolution of increased competitive ability. Frontiers in Ecology and the Environment 2:436-443.

Calosi, P., D. T. Bilton, and J. I. Spicer. 2008. Thermal tolerance, acclimatory capacity and vulnerability to global climate change. Biology Letters 4:99102.

Calosi, P., D. T. Bilton, J. I. Spicer, S. C. Votier, and A. Atfield. 2010. What determines a species' geographical range? Thermal biology and latitudinal range size relationships in European diving beetles (Coleoptera: Dytiscidae). Journal of Animal Ecology 79:194-204.

Carlton, J. T. and A. N. Cohen. 2003. Episodic global dispersal in shallow water marine organisms: the case history of the European shore crabs Carcinus maenas and C. aestuarii. Journal of Biogeography 30:1809.

Carlton, J. T. A. A. N. C. 2003. Episodic global dispersal in sjallow water marine organisms: the case historu of the European shore crabs Carcinus maenas and C. aesturii. Journal of Biogeography 30:1809-1820.

Carveth, C. J., A. M. Widmer, and S. A. Bonar. 2006. Comparison of upper thermal tolerances of native and nonnative fish species in Arizona. Transactions of the American Fisheries Society 135:1433-1440.

Casanovas, O., F. Miró, J. M. Estanyol, E. Itarte, N. Agell, and O. Bachs. 2000. Osmotic stress regulates the stability of cyclin D1 in a p38SAPK2dependent manner. Journal of Biological Chemistry 275:35091-35097.

Castilho, P. C., B. A. Buckley, G. Somero, and B. A. Block. 2009. Heterologous hybridization to a complementary DNA microarray reveals the effect of thermal acclimation in the endothermic bluefin tuna (Thunnus orientalis). Molecular Ecology 18:2092-2102.

Catford, J. A., R. Jansson, and C. Nilsson. 2009. Reducing redundancy in invasion ecology by integrating hypotheses into a single theoretical framework. Diversity and Distributions 15:22-40.

Chase, J. M. 1999. To Grow or to Reproduce? The Role of Life-History Plasticity in Food Web Dynamics. The American Naturalist 154:571-586.

Chown, S., K. Gaston, and D. Robinson. 2004. Macrophysiology: large-scale patterns in physiological traits and their ecological implications. Functional Ecology 18:159-167.

Chown, S. L., S. Slabber, M. A. McGeoch, C. Janion, and H. P. Leinaas. 2007. Phenotypic plasticity mediates climate change responses among invasive and indigenous arthropods. Proceedings: Biological Sciences 274:25312537.

Cieluch, U., K. Anger, F. Aujoulat, F. Buchholz, M. Charmantier-Daures, and G. Charmantie. 2004. Ontogeny of osmoregulatory structures and functions in the green crab Carcinus maenas (Crustacea, Decapoda). J Exp Biol 207:325-336.

Clark, D., M. Lamare, and M. Barker. 2009. Response of sea urchin pluteus larvae (Echinodermata: Echinoidea) to reduced seawater $\mathrm{pH}:$ a 
comparison among a tropical, temperate, and a polar species. Marine Biology 156:1125-1137.

Claxton, W. T. and G. L. Mackie. 1998. Seasonal and depth variations in gametogenesis and spawning of Dreissena polymorpha and Dreissena bugensis in eastern Lake Erie. Canadian Journal of Zoology 76:20102019.

Cohen, A. N., J. Carlton, and M. Fountain. 1995. Introduction, dispersal and potential impacts of the green crab Carcinus maenas in San Francisco Bay, California. Marine Biology 122:225-237.

Cohen, A. N. and J. T. Carlton. 1998. Accelerating invasion rate in a highly invaded estuary. Science 279:555-558.

Comeau, S., R. Jeffree, J.-L. Teyssié, and J.-P. Gattuso. 2010. Response of the Arctic Pteropod Limacina helicina to Projected Future Environmental Conditions. PLoS ONE 5:e11362.

Compton, T., J. Leathwick, and G. Inglis. 2010. Thermogeography predicts the potential global range of the invasive European green crab (Carcinus maenas). Diversity and Distributions 16:243-255.

Cowling, J. E., J. I. Spicer, J. M. Weeks, and K. J. Gaston. 2003. Environmental tolerances of an invasive terrestrial amphipod, Arcitalitrus dorrieni (Hunt) in Britain. Comparative Biochemistry and Physiology-Part A: Molecular \& Integrative Physiology 136:735-747.

Cox, G., P. Moseley, and G. W. Hunninghake. 1993. Induction of heat-shock protein 70 in neutrophils during exposure to subphysiologic temperatures. The Journal of Infectious Diseases 167:769-771.

Cox, T. J. and J. C. Rutherford. 2000. Thermal tolerances of two stream invertebrates exposed to diumally varying temperature. New Zealand Journal of Marine and Freshwater Research 34:203-208.

Coyne, J. A. and E. Beecham. 1987. Heritability of two morphological characters within and among natural populations of Drosophila melanogaster. Genetics 117:727-737.

Creutzberg, F. and M. Fonds. 1971. The seasonal variation in the distribution of some demersal fish species in the Dutch Wadden Sea. Thalassia Jugoslavica 7.

Crothers, J. H. 1968. The biology of Carcinus maenas. Field Studies 2:549-614.

Crozier, L. 2003. Winter warming facilitates range expansion: cold tolerance of the butterfly Atalopedes campestris. Oecologia 135:648-656.

Crozier, L. 2004. Warmer winters drive butterfly range expansion by increasing survivorship. Ecology 85:231-241.

Cuculescu, M., D. Hyde, and K. Bowler. 1998. Thermal tolerance of two species of marine crab, Cancer pagurus and Carcinus maenas. Journal of Thermal Biology 23:107-110.

Currie, R., W. Bennett, and T. Beitinger. 1998. Critical thermal minima and maxima of three freshwater game-fish species acclimated to constant temperatures. Environmental Biology of Fishes 51:187-200. 
Dallas, H. F. and N. A. Rivers-Moore. 2012. Critical Thermal Maxima of aquatic macroinvertebrates: towards identifying bioindicators of thermal alteration. Hydrobiologia 679:61-76.

Darling, J. A., M. J. Bagley, J. O. Roman, C. K. Tepolt, and J. B. Geller. 2008. Genetic patterns across multiple introductions of the globally invasive crab genus Carcinus. Molecular Ecology 17:4992-5007.

David, J. R., P. Gibert, E. Gravot, G. Petavy, J.-P. Morin, D. Karan, and B. Moreteau. 1997. Phenotypic plasticity and developmental temperature in Drosophila: Analysis and significance of reaction norms of morphometrical traits. Journal of Thermal Biology 22:441-451.

de Rivera, C., N. Hitchcock, S. Teck, B. Steves, A. Hines, and G. Ruiz. 2007. Larval development rate predicts range expansion of an introduced crab. Marine Biology 150:1275-1288.

de Rivera, C. E., B. P. Steves, P. W. Fofonoff, A. H. Hines, and G. M. Ruiz. 2011. Potential for high-latitude marine invasions along western North America. Diversity and Distributions 17:1198-1209.

de Rivera, C. E., B. P. Steves, G. M. Ruiz, P. W. Fofonoff, and A. H. Hines. 2006. Northward spread of marine nonindigenous species along western North America: forecasting risk of colonization in Alaskan waters using environmental niche modeling.in P. W. S. R. C. A. C. U. S. F. W. Service, editor.

Derham, B. K. and J. J. Harding. 1999. a-Crystallin as a molecular chaperone. Progress in Retinal and Eye Research 18:463-509.

Dethier, M. N. and S. D. Hacker. 2005. Physical factors vs. biotic resistance in controlling the invasion of an estuarine marsh grass. Ecological Applications 15:1273-1283.

Díaz Herrera, F., E. Sierra Uribe, L. Fernando Bückle Ramirez, and A. Garrido Mora. 1998. Critical thermal maxima and minima of Macrobrachium rosenbergii (Decapoda: Palaemonidae). Journal of Thermal Biology 23:381-385.

Dietz, T. J. and G. N. Somero. 1992. The threshold induction temperature of the 90-kDa heat shock protein is subject to acclimatization in eurythermal goby fishes (genus Gillichthys). Proceedings of the National Academy of Sciences 89:3389-3393.

Elner, R. and R. N. Hughes. 1978. Energy maximization in the diet of the shore crab, Carcinus maenas. The Journal of Animal Ecology:103-116.

Elner, R. W. 1978. The mechanics of predation by the shore crab, Carcinus maenas (L.), on the edible mussel, Mytilus edulis L. Oecologia 36:333344.

Elton, C. S. 1958. The ecology of invasions by plants and animals. Methuen, London 18.

Eriksson, S. and A.-M. Edlund. 1977. On the ecological energetics of 0-group Carcinus maenas (L.) from a shallow sandy bottom in gullmar fjord, Sweden. Journal of Experimental Marine Biology and Ecology 30:233-248. 
Fabry, V. J., B. A. Seibel, R. A. Feely, and J. C. Orr. 2008. Impacts of ocean acidification on marine fauna and ecosystem processes. ICES Journal of Marine Science: Journal du Conseil 65:414-432.

Fangue, N. A., M. Hofmeister, and P. M. Schulte. 2006. Intraspecific variation in thermal tolerance and heat shock protein gene expression in common killifish, Fundulus heteroclitus. Journal of Experimental Biology 209:28592872.

Feder, M. E. and G. E. Hofmann. 1999. Heat-shock proteins, molecular chaperones, and the stress response: Evolutionary and Ecological Physiology. Annual Review of Physiology 61:243-282.

Fields, P. A., E. L. Rudomin, and G. N. Somero. 2006. Temperature sensitivities of cytosolic malate dehydrogenases from native and invasive species of marine mussels (genus Mytilus): sequence-function linkages and correlations with biogeographic distribution. Journal of Experimental Biology 209:656-667.

Fields, R., S. S. Lowe, C. Kaminski, G. S. Whitt, and D. P. Philipp. 1987. Critical and chronic thermal maxima of northern and Florida largemouth bass and their reciprocal F1 and F2 hybrids. Transactions of the American Fisheries Society 116:856-863.

Fink, A. L. 1999. Chaperone-mediated protein folding. Physiological Reviews 79:425-449.

Fletcher, N. and J. D. Hardege. 2009. The cost of conflict: agonistic encounters influence responses to chemical signals in the European shore crab. Animal Behaviour 77:357-361.

Forcella, F. and J. Wood. 1984. Colonization potentials of alien weeds are related to their 'native' distributions: implications for plant quarantine. Journal of the Australian Institute of Agricultural Science 50:35-40.

Fowler, A., N. Gerner, and M. Sewell. 2011. Temperature and salinity tolerances of Stage 1 zoeae predict possible range expansion of an introduced portunid crab, Charybdis japonica, in New Zealand. Biological Invasions 13:691-699.

Fowler, S. and M. F. Thomashow. 2002. Arabidopsis transcriptome profiling indicates that multiple regulatory pathways are activated during cold acclimation in addition to the CBF cold response pathway. The Plant Cell Online 14:1675-1690.

Frederich, M., M. R. O'Rourke, N. B. Furey, and J. A. Jost. 2009. AMP-activated protein kinase (AMPK) in the rock crab, Cancer irroratus: an early indicator of temperature stress. Journal of Experimental Biology 212:722730.

Fu, M., C. Wang, Z. Li, T. Sakamaki, and R. G. Pestell. 2004. Minireview: Cyclin D1: Normal and abnormal functions. Endocrinology 145:5439-5447.

Fujita, J. 1999. Cold shock response in mammalian cells. Journal of molecular microbiology and biotechnology 1:243-255. 
Gardner, J. L., A. Peters, M. R. Kearney, L. Joseph, and R. Heinsohn. 2011. Declining body size: a third universal response to warming? Trends in Ecology \&amp; Evolution 26:285-291.

Garm, A. 2005. Mechanosensory properties of the mouthpart setae of the European shore crab Carcinus maenas. Marine Biology 147:1179-1190.

Gaston, Kevin J., Steven L. Chown, P. Calosi, J. Bernardo, David T. Bilton, A. Clarke, S. ClusellaTrullas, Cameron K. Ghalambor, M. Konarzewski, Lloyd S. Peck, Warren P. Porter, Hans O. Pörtner, Enrico L. Rezende, Patricia M. Schulte, John I. Spicer, Jonathon H. Stillman, John S. Terblanche, and M. van Kleunen. 2009. Macrophysiology: A conceptual reunification. The American Naturalist 174:595-612.

Gattuso, J.-P., D. Allemand, and M. Frankignoulle. 1999. Photosynthesis and calcification at cellular, organismal and community levels in coral reefs: a review on interactions and control by carbonate chemistry. American Zoologist 39:160-183.

Gerhardt, F. and S. K. Collinge. 2007. Abiotic constraints eclipse biotic resistance in determining invasibility along experimental vernal pool gradients. Ecological Applications 17:922-933.

Gibert, P. and G. De Jong. 2001. Temperature dependence of development rate and adult size in Drosophila species: biophysical parameters. Journal of Evolutionary Biology 14:267-276.

Gillespie, G. E., A. C. Phillips, Paltzat, D.L., and T. W. Therriault. 2007. Status of the European green crab, Carcinus maenas in British Columbia-2006. Page 39 in C. T. R. o. F. a. A. Sciences, editor.

Gilligan, M. 1991. Bergmann ecogeographic trends among triplefin blennies (Teleostei: Tripterygiidae) in the Gulf of California, Mexico. Environmental Biology of Fishes 31:301-305.

González, R. A., F. Díaz, A. Licea, A. Denisse Re, L. Noemí Sánchez, and Z. García-Esquivel. 2010. Thermal preference, tolerance and oxygen consumption of adult white shrimp Litopenaeus vannamei (Boone) exposed to different acclimation temperatures. Journal of Thermal Biology 35:218-224.

Gordon, D. R. 1998. Effects of invasive, non-Indigenous plant species on ecosystem processes: lessons from Florida. Ecological Applications 8:975-989.

Gracey, A. Y., M. L. Chaney, J. P. Boomhower, W. R. Tyburczy, K. Connor, and G. N. Somero. 2008. Rhythms of gene expression in a fluctuating intertidal environment. Current Biology 18:1501-1507.

Grosholz, E. 2002. Ecological and evolutionary consequences of coastal invasions. Trends in Ecology \& Evolution 17:22-27.

Grosholz, E. D. and G. M. Ruiz. 1996. Predicting the impact of introduced marine species: Lessons from the multiple invasions of the European green crab Carcinus maenas. Biological Conservation 78:59-66. 
Grosholz, E. D. and G. M. Ruiz. 2003. Biological invasions drive size increases in marine and estuarine invertebrates. Ecology Letters 6:700-705.

Grosholz, E. D. A. G. M. R. 1995. Spread and potential impact of the recently introduced European green crab, Carcinus maenas in central California. Marine Biology 122:239-247.

Grosholz, E. D. A. G. M. R. e. a. 2000. The impact of a nonindigenous marine predator on multple trophic levels. Ecology 81:1206-1224.

Guo, Z., J. Wang, J. Yang, N.-h. Wu, Y. Zhang, and Y.-f. Shen. 2009. An inhibitory role of p53 via NF-kB element on the cyclin D1 gene under heat shock. Biochimica et Biophysica Acta (BBA) - Gene Regulatory Mechanisms 1789:758-762.

Hadlock, R. P. 1980. Alarm response of the intertidal snail Littorina littorea to predation by the crab Carcinus maenas. Biological Bullitin of Marine Biology 159:269-279.

Han, S. I., S. Y. Oh, W. J. Jeon, J. M. Kim, J. H. Lee, H. Y. Chung, Y. H. Choi, M. A. Yoo, H. D. Kim, and H. S. Kang. 2002. Mild heat shock induces cyclin D1 synthesis through multiple Ras signal pathways. FEBS Letters 515:141-145.

Hänfling, B., F. Edwards, and F. Gherardi. 2011. Invasive alien Crustacea: dispersal, establishment, impact and control. BioControl 56:573-595.

Harley, C. D., A. Randall Hughes, K. M. Hultgren, B. G. Miner, C. J. Sorte, C. S. Thornber, L. F. Rodriguez, L. Tomanek, and S. L. Williams. 2006. The impacts of climate change in coastal marine systems. Ecology Letters 9:228-241.

Harris, L. G. and M. C. Tyrrell. 2001. Changing community states in the Gulf of Maine: synergism between invaders, overfishing and climate change. Biological Invasions 3:9-21.

Hart, J. S. 1952. Geographic variations of some physiological and morphological characters in certain freshwater fish. University of Toronto Press.

Hassol, S. 2004. Impacts of a Warming Arctic-Arctic Climate Impact Assessment. Cambridge University Press.

Hazel, J. R. 1995. Thermal adaptation in biological membranes: is homeoviscous adaptation the explanation? Annual Review of Physiology 57:19-42.

Heath, J. R. and H. Barnes. 1970. Some changes in biochemical composition with season and during the moulting cycle of the common shore crab, Carcinus maenas (L.). Journal of Experimental Marine Biology and Ecology 5:199-233.

Helmuth, B., C. Harley, P. Halpin, I. M. O'Donnel, G. Hofmann, and C. Blanchette. 2002. Climate change and latitudinal patterns of intertidal thermal stress. Science 298:1015.

Helmuth, B., J. G. Kingsolver, and E. Carrington. 2005. Biophysics, physiological ecology, and climate change: does mechanism matter? Annu. Rev. Physiol. 67:177-201. 
Henkel, S. and G. Hofmann. 2008. Differing patterns of hsp70 gene expression in invasive and native kelp species: evidence for acclimation-induced variation. Journal of Applied Phycology 20:915-924.

Henkel, S. K. and G. E. Hofmann. 2009. Differing patterns of hsp70 gene expression in invasive and native kelp species: evidence for acclimationinduced variation. Pages 465-474 in Nineteenth International Seaweed Symposium. Springer.

Hines, A. 1988. Fecundity and Reproductive Output in Two Species of Deep-Sea Crabs, Geryon fenneri and G. quinquedens (Decapoda: Brachyura). Journal of Crustacean Biology 8:557-562.

Hines, A. H. 1982. Allometric constraints and variables of reproductive effort in brachyuran crabs. Marine Biology 69:309-320.

Hines, A. H. 1989. Geographic variation in size at Maturity in brachyuran crabs. Bulletin of Marine Science 45:356-368.

Hobbs, R. J. and S. E. Humphries. 1995. An integrated approach to the ecology and management of plant invasions. Conservation Biology 9:761-770.

Hochachka, P. W. and G. N. Somero. 2002. Biochemical adaptation : mechanism and process in physiological evolution. Oxford Univ. Press, Oxford [u.a.].

Hofmann, G. and G. Somero. 1995. Evidence for protein damage at environmental temperatures: seasonal changes in levels of ubiquitin conjugates and hsp70 in the intertidal mussel Mytilus trossulus. Journal of Experimental Biology 198:1509-1518.

Hofmann, G. and G. Somero. 1996a. Interspecific variation in thermal denaturation of proteins in the congeneric mussels Mytilus trossulus and M. galloprovincialis: evidence from the heat-shock response and protein ubiquitination. Marine Biology 126:65-75.

Hofmann, G. E., B. A. Buckley, S. Airaksinen, J. E. Keen, and G. N. Somero. 2000. Heat-shock protein expression is absent in the antarctic fish Trematomus bernacchii (family Nototheniidae). Journal of Experimental Biology 203:2331-2339.

Hofmann, G. E. and G. N. Somero. 1996b. Interspecific variation in thermal denaturation of proteins in the congeneric mussels Mytilus trossulus and M. galloprovincialis: evidence from the heat-shock response and protein ubiquitination. Marine Biology 126:65-75.

Hofmann, G. E. and A. E. Todgham. 2010. Living in the now: Physiological mechanisms to tolerate a rapidly changing environment. Annual Review of Physiology 72:127-145.

Holland, D. B., S. G. Roberts, E. J. Wood, and W. J. Cunliffe. 1993. Cold shock induces the synthesis of stress proteins in human keratinocytes. Journal of Investigative Dermatology 101:196-199.

Holt, R., M. Barfield, and R. Gomulkiewicz. 2005. Theories of niche conservatism and evolution: could exotic species be potential tests. Species invasions: insights into ecology, evolution, and biogeography:259-290. 
Holway, D. A., A. V. Suarez, and T. J. Case. 2002. Role of abiotic factors in governing susceptibility to invasion: a test with Argentine Ants. Ecology 83:1610-1619.

Hone, D. W. E. and M. J. Benton. 2005. The evolution of large size: how does Cope's Rule work? Trends in Ecology and Evolution 20:4-6.

Horwitz, J. 1992. Alpha-crystallin can function as a molecular chaperone. Proceedings of the National Academy of Sciences 89:10449-10453.

Horwitz, J., T. Emmons, and L. Takemoto. 1992. The ability of lens alpha crystallin to protect against heat-induced aggregation is age-dependent. Current eye research 11:817-822.

Hutchison, V. H. and J. D. Maness. 1979. The role of behavior in temperature acclimation and tolerance in ectotherms. American Zoologist 19:367-384.

Huxley, J. S. and O. W. Richards. 1931. Relative Growth of the abdomen and the carapace of the Shore-Crab Carcinus maenas. Journal of the Marine Biological Association of the United Kingdom (New Series) 17:1001-1015.

Jacobson, M. Z. 2005. Studying ocean acidification with conservative, stable numerical schemes for nonequilibrium air-ocean exchange and ocean equilibrium chemistry. Journal of geophysical research 110:D07302.

Jennings, S., S. P. R. Greenstreet, and J. D. Reynolds. 1999. Structural change in an exploited fish community: a consequence of differential fishing effects on species with contrasting life histories. Journal of Animal Ecology 68:617-627.

Jensen, G. C., P. S. McDonald, and D. A. Armstrong. 2007. Biotic resistance to green crab, Carcinus maenas, in California bays. Marine Biology 151:2231-2243.

Johnston, I. A. and A. F. Bennett. 2008. Animals and temperature: phenotypic and evolutionary adaptation. Cambridge University Press.

Johnston, I. A. and F. Bennett. 1996. Animals and Temperature: Phenotypic and Evolutionary Adaptation. Cambridge University Press.

Jones, S. J., N. Mieszkowska, and D. S. Wethey. 2009. Linking Thermal Tolerances and Biogeography: Mytilus edulis (L.) at its Southern Limit on the East Coast of the United States. The Biological Bulletin 217:73-85.

Jost, J., S. Podolski, and M. Frederich. 2012. Enhancing thermal tolerance by eliminating the pejus range: a comparative study with three decapod crustaceans. Marine Ecology Progress Series 444:263-274.

Jumbam, K., J. Terblanche, J. Deere, M. Somers, and S. Chown. 2008a. Critical thermal limits and their responses to acclimation in two sub-Antarctic spiders: Myro kerguelenensis and Prinerigone vagans. Polar Biology 31:215-220.

Jumbam, K. R., S. Jackson, J. S. Terblanche, M. A. McGeoch, and S. L. Chown. 2008b. Acclimation effects on critical and lethal thermal limits of workers of the Argentine ant, Linepithema humile. Journal of Insect Physiology 54:1008-1014. 
Kamermans, P., M. Blankendaal, and J. Perdon. 2009. Predation of shore crabs (Carcinus maenas (L.)) and starfish (Asterias rubens L.) on blue mussel (Mytilus edulis L.) seed from wild sources and spat collectors. Aquaculture 290:256-262.

Karlsson, B. and C. Wiklund. 2005. Butterfly life history and temperature adaptations; dry open habitats select for increased fecundity and longevity. Journal of Animal Ecology 74:99-104.

Kelley, A. L., C. E. de Rivera, and B. A. Buckley. 2011. Intraspecific variation in thermotolerance and morphology of the invasive European green crab, Carcinus maenas, on the west coast of North America. Journal of Experimental Marine Biology and Ecology 409:70-78.

Kelley, A. L., C. E. de Rivera, and B. A. Buckley. 2013. Cold tolerance of the invasive Carcinus maenas in the east Pacific: molecular mechanisms and implications for range expansion in a changing climate. Biological Invasions:1-11.

Kennedy, V. S. and J. A. Mihursky. 1971. Upper temperature tolerances of some estuarine bivalves. Chesapeake Science 12:193-204.

Kennedy, V. S., R. R. Twilley, J. A. Kleypas, J. H. Cowan Jr, and S. R. Hare. 2002. Coastal and Marine Ecosystems \& Global Climate Change: Potential Effects on US Resources.

Klein Breteler, W. C. M. 1975. Laboratory experiments on the influence of environmental factors on the frequency of moulting and the increase in size at moulting of juvenile shore crabs, Carcinus maenas. Netherlands Journal of Sea Research 9:100-120.

Kozloff, E. N. 1983. Seashore life of the northern Pacific coast : an illustrated guide to northern California, Oregon, Washington, and British Columbia. University of Washington Press, Seattle.

Krebs, R. A. and S. H. Holbrook. 2001. Reduced enzyme activity following Hsp70 overexpression in Drosophila melanogaster. Biochemical Genetics 39:7382.

Kültz, D. 2003. Evolution of the cellular stress proteome: from monophyletic origin to ubiquitous function. Journal of Experimental Biology 206:31193124.

Kültz, D. 2005. Molecular and evolutionary basis of the cellular stress response. Pages 225-257 Annual Review of Physiology. Annual Reviews, Palo Alto.

Kumlu, M., S. Türkmen, and M. Kumlu. 2010. Thermal tolerance of Litopenaeus vannamei (Crustacea: Penaeidae) acclimated to four temperatures. Journal of Thermal Biology 35:305-308.

Laios, E., I. M. Rebeyka, and C. A. Prody. 1997. Characterization of cold-induced heat shock protein expression in neonatal rat cardiomyocytes. Molecular and Cellular Biochemistry 173:153-159.

Lee, C. E., J. L. Remfert, and G. W. Gelembiuk. 2003. Evolution of physiological tolerance and performance during freshwater invasions. Integrative and Comparative Biology 43:439-449. 
Lee, Y.-J., H.-N. Cho, D.-I. Jeoung, J.-W. Soh, C. K. Cho, S. Bae, H.-Y. Chung, S.-J. Lee, and Y.-S. Lee. 2004. HSP25 overexpression attenuates oxidative stress-induced apoptosis: roles of ERK1/2 signaling and manganese superoxide dismutase. Free radical biology \& medicine 36:429.

Levine, J. M. 2000. Species diversity and biological invasions: relating local process to community pattern. Science 288:852-854.

Lewis, D. H. and R. D. Roer. 1988. Thermal preference in distribution of blue crabs, Callinectes sapidus, in a power plant cooling pond. Journal of Crustacean Biology:283-289.

Lindquist, S. 1986. The heat-shock response. Annual review of biochemistry 55:1151-1191.

Lockwood, B. L., J. G. Sanders, and G. N. Somero. 2010. Transcriptomic responses to heat stress in invasive and native blue mussels (genus Mytilus): molecular correlates of invasive success. The Journal of Experimental Biology 213:3548-3558.

Lockwood, B. L. and G. N. Somero. 2011. Invasive and native blue mussels Mytilus on the California coast: The role of physiology in a biological invasion. Journal of Experimental Marine Biology and Ecology 400:167174.

Lohr, S., P. A. Byorth, C. Kaya, and W. Dwyer. 1996. High-temperature tolerances of fluvial Arctic grayling and comparisons with summer river temperatures of the Big Hole River, Montana. Transactions of the American Fisheries Society 125:933-939.

Lohrer, A. M., Y. Fukui, K. Wada, and R. B. Whitlatch. 2000. Structural complexity and vertical zonation of intertidal crabs, with focus on habitat requirements of the invasive Asian shore crab, Hemigrapsus sanguineus (de Haan). Journal of Experimental Marine Biology and Ecology 244:203217.

Lonsdale, D. J. and J. S. Levinton. 1985. Latitudinal differentiation in copepod growth: an adaptation to temperature. Ecology:1397-1407.

Lonsdale, W. M. 1999. Global patterns of plant invasions and the concept of invasibility. Ecology 80:1522-1536.

Macpherson, E. and C. M. Duarte. 2006. Patterns in species richness, size, and latitudinal range of East Atlantic fishes. Ecography 17:242-248.

McCauley, R. 1958. Thermal relations of geographic races of Salvelinus. Canadian Journal of Zoology 36:655-662.

McClellan, A. J., Y. Xia, A. M. Deutschbauer, R. W. Davis, M. Gerstein, and J. Frydman. 2007. Diverse cellular functions of the Hsp90 molecular chaperone uncovered using systems approaches. Cell 131:121-135.

McGaw, I., T. Edgell, and M. Kaiser. 2011. Population demographics of native and newly invasive populations of the green crab Carcinus maenas. Marine Ecology Progress Series 430:235-240. 
McGaw, I. J. and E. Naylor. 1992. Salinity preference of the shore crab Carcinus maenas in relation to coloration during intermoult and to prior acclimation. Journal of Experimental Marine Biology and Ecology 155:145-159.

McMahon, R. F. 2002. Evolutionary and physiological adaptations of aquatic invasive animals: $r$ selection versus resistance. Canadian Journal of Fisheries and Aquatic Sciences 59:1235-1244.

McQuaid, C., J. Lindsay, and T. Lindsay. 2000. Interactive effects of wave exposure and tidal height on population structure of the mussel Perna perna. Marine Biology 137:925-932.

McVean, A. 1976. The incidence of autotomy in Carcinus maenas (L.). Journal of Experimental Marine Biology and Ecology 24:177-187.

Meehl, G., W. Collins, P. Friedlingstein, A. Gaye, and e. al. 2007. Global Climate Projections. In: Climate Change 2007: The Physical Science Basis. .in Change, editor. University Press, Cambridge, Cambridge, United Kingdom and New York, NY, USA.

Mills, E. I., G. Rosenberg, A. Spidle, M. Ludyanskiy, Y. Pligin, and B. May. 1996. A Review of the Biology and Ecology of the Quagga Mussel (Dreissena bugensis), a Second Species of Freshwater Dreissenid Introduced to North America. American Zoologist 36:271-286.

Mohamedeen, H. and R. G. Hartnoll. 1990. Larval and postlarval growth of individually reared specimens of the common shore crab Carcinus maenas (L.). Journal of Experimental Marine Biology and Ecology 134:124.

Mohai, P. 1985. Public concern and elite involvement in environmentalconservation issues. Social Science Quarterly 66:820-838.

Moksnes, P.-O. 2004. Interference competition for space in nursery habitats: density-dependent effects on growth and dispersal in juvenile shore crabs Carcinus maenas. Marine Ecology Progress Series 281:181-191.

Morgan, D. O. 1997. Cyclin-dependant kinases: engines, clocks, and microprocessors. Annual Review of Cell and Developmental Biology 13:261-291.

Morin, M. and D. Pétavy. 1999. Divergence of reaction norms of size characters between tropical and temperate populations of Drosophila melanogaster and D. simulans. Journal of Evolutionary Biology 12:329-339.

Moser, S. C. and L. Dilling. 2004. Making climate hot. Environment: Science and Policy for Sustainable Development 46:32-46.

Moyle, P. B. and M. P. Marchetti. 2006. Predicting invasion success: Freshwater fishes in California as a model. BioScience 56:515-524.

Mukhopadhyay, A., S. Banerjee, L. J. Stafford, C. Xia, M. Liu, and B. B. Aggarwal. 2002. Curcumin-induced suppression of cell proliferation correlates with down-regulation of cyclin D1 expression and CDK4mediated retinoblastoma protein phosphorylation. Oncogene 21:88528861. 
Naganuma, K. H. and J. D. Roughgarden. 1990. Optimal body size in lesser Antillean Anolis lizards--A mechanistic approach. Ecological Monographs 60:239-256.

Nagaraj, M. 1993a. Combined effects of temperature and salinity on the zoeal development of the green crab, Carcinus maenas (Linnaeus, 1758)(Decapoda: Portunidae). Science Marine 57:1-8.

Nagaraj, M. 1993b. Combined effects of temperature and salinity on the zoel development of the green crab, Carcinus maenas,. Scientia Marina 57:18.

Nalepa, T. F. and D. W. Schloesser. 1993. Zebra mussels : biology, impacts, and control. Lewis Publishers, Boca Raton, Fla.

Nijhout, H. F., G. Davidowitz, and D. A. Roff. 2006. A quantitative analysis of the mechanism that controls body size in Manduca sexta. Journal of biology 5 .

Nitta, M., H. Okamura, S. Aizawa, and M. Yamaizumi. 1997. Heat shock induces transient p53-dependent cell cycle arrest at G1/S. Oncogene 15:561.

Norry, F. M. and V. Loeschcke. 2002. Temperature-induced shifts in associations of longevity with body size in Drosophila melanogaster. Evolution 56:299306.

NRC, N. R. C.-. 2011. Climate stabilization targets emissions, concentrations, and impacts over decades to millennia. National Academies Press, Washington, D.C.

O' Donnell, M., A. Todgham, M. Sewell, L. Hammond, K. Ruggiero, N. Fangue, M. Zippay, and G. Hofmann. 2010. Ocean acidification alters skeletogenesis and gene expression in larval sea urchins. Marine Ecology Progress Series 398:157-171.

Ohnishi, T., X. Wang, K. Ohnishi, and A. Takahashi. 1998. p53-dependent induction of WAF1 by cold shock in human glioblastoma cells. Oncogene 16:1507.

Olyarnik, S., M. S. Bracken, J. Byrnes, A. R. Hughes, K. Hultgren, and J. Stachowicz. 2009. Ecological factors affecting community invasibility. Pages 215-238 in G. Rilov and J. Crooks, editors. Biological Invasions in Marine Ecosystems. Springer Berlin Heidelberg.

Osovitz, C. J. and G. E. Hofmann. 2005. Thermal history-dependent expression of the hsp70 gene in purple sea urchins: Biogeographic patterns and the effect of temperature acclimation. Journal of Experimental Marine Biology and Ecology 327:134-143.

Overgaard, J., A. Tomčala, J. G. Sørensen, M. Holmstrup, P. H. Krogh, P. Šimek, and V. Koštál. 2008. Effects of acclimation temperature on thermal tolerance and membrane phospholipid composition in the fruit fly Drosophila melanogaster. Journal of Insect Physiology 54:619-629.

Pandolfo, T. J., W. G. Cope, C. Arellano, R. B. Bringolf, M. C. Barnhart, and E. Hammer. 2010. Upper thermal tolerances of early life stages of freshwater mussels. Journal of the North American Benthological Society 29:959-969. 
Parmesan, C. 2006. Ecological and evolutionary responses to recent climate change. Annual Review of Ecology, Evolution, and Systematics 37:637669.

Parmesan, C. and G. Yohe. 2003. A globally coherent fingerprint of climate change impacts across natural systems. Nature 421:37.

Partridge, L., B. Barrie, K. Fowler, and V. French. 1994. Evolution and development of body size and cell size in Drosophila melanogaster in response to temperature. Evolution:1269-1276.

Partridge, L. and J. A. Coyne. 1997. Bergmann's rule in ectotherms: is it adaptive? Evolution 51:632-635.

Partridge, L. and K. Fowler. 1993. Responses and correlated responses to artificial selection on thorax length in Drosophila melanogaster. Evolution 47:213-226.

Partridge, L. and V. French. 1996. Thermal evolution of ectotherm body size: why get big in the cold. Animals and temperature: Phenotypic and evolutionary adaptation 59:265.

Partridge, L. B., B. Fowler, K. French, V. 1994. Evolution and development of body size and cell size in Drosophila melanogaster in response to temperature. Evolution; international journal of organic evolution 48:12691276.

Patz, J. A., D. Campbell-Lendrum, T. Holloway, and J. A. Foley. 2005. Impact of regional climate change on human health. Nature 438:310-317.

Pedersen, K. L., S. N. Pedersen, P. Højrup, J. S. Andersen, P. Roepstorff, J. Knudsen, and M. H. Depledge. 1994. Purification and characterization of a cadmium-induced metallothionein from the shore crab Carcinus maenas (L.). The Biochemical journal 297:609-614.

Perkins E.J. E. Gribbon, a. R. B. M. 1969. Some aspects of the biology of Carcinus maenas. Survival at low salinity. Transactions, Journal and Proceedings of the Dumphrieshire and Galloway Natural History and Antiquity Society 46:27-28.

Peters, R. H. 1983. The ecological implications of body size. Cambridge University Press, Cambridge [Cambridgeshire]; New York.

Peterson, A. T. 2003. Predicting the geography of species' invasions via ecological niche modeling. The Quarterly Review of Biology 78:419-433.

Piaget, J. 1932. The moral judgment of the child. Routledge \& Kegan Paul, London.

Piaget, J. 1936. Origins of intelligence in the child. Routledge \& Kegan Paul, London.

Piaget, J. 1957. Construction of reality in the child. Routledge \& Kegan Paul., London.

Pigliucci, M. 2001. Phenotypic plasticity : beyond nature and nurture. Johns Hopkins University Press, Baltimore. 
Pimentel, D., R. Zuniga, and D. Morrison. 2005. Update on the environmental and economic costs associated with alien-invasive species in the United States. Ecological Economics 52:273-288.

Podrabsky, J. E., I. D. Garrett, and Z. F. Kohl. 2010. Alternative developmental pathways associated with diapause regulated by temperature and maternal influences in embryos of the annual killifish Austrofundulus limnaeus. The Journal of Experimental Biology 213:3280-3288.

Pörtner, H. 2002. Climate variations and the physiological basis of temperature dependent biogeography: systemic to molecular hierarchy of thermal tolerance in animals. Comparative Biochemistry and Physiology-Part A: Molecular \& Integrative Physiology 132:739-761.

Pörtner, H., B. Berdal, R. Blust, O. Brix, A. Colosimo, B. De Wachter, A. Giuliani, T. Johansen, T. Fischer, and R. Knust. 2001. Climate induced temperature effects on growth performance, fecundity and recruitment in marine fish: developing a hypothesis for cause and effect relationships in Atlantic cod Gadus morhua and common eelpout (Zoarces viviparus). Continental Shelf Research 21:1975-1997.

Pörtner, H., M. Langenbuch, and B. Michaelidis. 2005. Synergistic effects of temperature extremes, hypoxia, and increases in $\mathrm{CO} 2$ on marine animals: From Earth history to global change. J. Geophys. Res. 110:C09S10.

Pörtner, H., M. Langenbuch, and A. Reipschläger. 2004. Biological Impact of Elevated Ocean $\mathrm{CO}_{2}$ concentrations: lessons from animal physiology and earth history. Journal of Oceanography 60:705-718.

Pratt, W. B. 1998. The hsp90-based chaperone system: involvement in signal transduction from a variety of hormone and growth factor receptors. Pages 420-434 in Proceedings of the Society for Experimental Biology and Medicine. Society for Experimental Biology and Medicine (New York, NY). Royal Society of Medicine.

Prosser, C. L. 1991. Comparative Animal Physiology, Environmental and Metabolic Animal Physiology. Wiley-Liss.

Pyšek, P., V. Jarošík, J. Pergl, R. Randall, M. Chytrý, I. Kühn, L. Tichý, J. Danihelka, J. Chrtek jun, and J. Sádlo. 2009. The global invasion success of central European plants is related to distribution characteristics in their native range and species traits. Diversity and Distributions 15:891-903.

Pyšek, P. and D. M. Richardson. 2007. Traits associated with invasiveness in alien plants: where do we stand? Biological Invasions:97-125.

Quinn, J. M., G. L. Steele, C. W. Hickey, and M. L. Vickers. 1994. Upper thermal tolerances of twelve New Zealand stream invertebrate species. New Zealand Journal of Marine and Freshwater Research 28:391-397.

Ramakrishnan, V. 2007. Salinity, pH, temperature, desiccation and hypoxia tolerance in the invasive freshwater apple snail, Pomacea insularum. University of Texas at Arlington, Arlington, Texas. 
Rawlings, T., K. Hayes, R. Cowie, and T. Collins. 2007. The identity, distribution, and impacts of non-native apple snails in the continental United States. BMC Evolutionary Biology 7:97.

Rejmanek, M. 2000. Invasive plants: approaches and predictions. Austral ecology 25:497-506.

Rejmánek, M. 1996. A theory of seed plant invasiveness: the first sketch. Biological Conservation 78:171-181.

Rejmánek, M., P. Pyšek, K. Prach, and M. Wade. 1995. What makes a species invasive? Pages 3-13 in Plant invasions: general aspects and special problems. Workshop held at Kostelec nad Černými lesy, Czech Republic, 16-19 September 1993. SPB Academic Publishing.

Resnitzky, D. and S. Reed. 1995. Different roles for cyclins D1 and E in regulation of the G1-to-S transition. Mol. Cell. Biol. 15:3463-3469.

Riessen, H. P. 1999. Predator-induced life history shifts in Daphnia: a synthesis of studies using meta-analysis. Canadian Journal of Fisheries and Aquatic Sciences 56:2487-2494.

Rinehart, J. P., S. A. L. Hayward, M. A. Elnitsky, L. H. Sandro, R. E. Lee, and D. L. Denlinger. 2006. Continuous up-regulation of heat shock proteins in larvae, but not adults, of a polar insect. Proceedings of the National Academy of Sciences 103:14223-14227.

Roberts, D. A., G. E. Hofmann, and G. N. Somero. 1997. Heat-shock protein expression in Mytilus californianus: acclimatization (seasonal and tidalheight comparisons) and acclimation effects. The Biological Bulletin 192:309-320.

Roessig, J. M., C. M. Woodley, J. J. Cech, and L. J. Hansen. 2004. Effects of global climate change on marine and estuarine fishes and fisheries. Reviews in Fish Biology and Fisheries 14:251-275.

Roff, D. A. 2002. Life History Evolution. Sinauer Associates Inc. , Sunderland.

Rome, M., A. Young-Williams, G. Davis, and A. H. Hines. 2005. Linking temperature and salinity tolerance to winter mortality of Chesapeake Bay blue crabs Callinectes sapidus. Journal of Experimental Marine Biology and Ecology 319:129-145.

Ropes, J. W. 1968. The feeding habits of the green crab, Carcinus maenas. Fishery Bullitin 67:183-2003.

Rowley, A., G. C. Johnston, B. Butler, M. Werner-Washburne, and R. A. Singer. 1993. Heat shock-mediated cell cycle blockage and G1 cyclin expression in the yeast Saccharomyces cerevisiae. Molecular and Cellular Biology 13:1034-1041.

Ruiz, G. M., P. W. Fofonoff, J. T. Carlton, M. J. Wonham, and A. H. Hines. 2000. Invasion of coastal marine communities in North America: apparent patterns, processes, and biases. Annual Review of Ecology and Systematics:481-531. 
Sabine, C. L., R. A. Feely, N. Gruber, R. M. Key, K. Lee, J. L. Bullister, R. Wanninkhof, C. Wong, D. W. Wallace, and B. Tilbrook. 2004. The oceanic sink for anthropogenic CO2. Science 305:367-371.

Sakai, A. K., F. W. Allendorf, J. S. Holt, D. M. Lodge, J. Molofsky, K. A. With, S. Baughman, R. J. Cabin, J. E. Cohen, N. C. Ellstrand, D. E. McCauley, P. O'Neil, I. M. Parker, J. N. Thompson, and S. G. Weller. 2001. The population biology of invasive species. Annual Review of Ecology and Systematics 32:305-332.

Sampetrean, O., S.-i. lida, S. Makino, Y. Matsuzaki, K. Ohno, and H. Saya. 2009. Reversible whole-organism cell cycle arrest in a living vertebrate. Cell Cycle 8:620-627.

Sanders, B. M. 1993. Stress proteins in aquatic organisms: an environmental perspective. CRC Critical Reviews in Toxicology 23:49-75.

Sanders, B. M., C. Hope, V. M. Pascoe, and L. S. Martin. 1991. Characterization of the stress protein response in two species of Collisella Limpets with different temperature tolerances. Physiological Zoology 64:1471-1489.

Sato, T. G., Seiji. 2007. Effects of risk of sperm competition, female size, and male size on number of ejaculated sperm in the stone crab Hapalogaster dentata. Journal of Crustacean Biology 27:570-575.

Sax, D. F., J. J. Stachowicz, and S. D. Gaines. 2005. Species invasions: insights into ecology, evolution, and biogeography. Sinauer Associates Sunderland.

Schoener, T. W. 1969. Models of optimal size for solitary predators. The American Naturalist 103:277-313.

See, K. and B. Feist. 2010. Reconstructing the range expansion and subsequent invasion of introduced European green crab along the west coast of the United States. Biological Invasions 12:1305-1318.

Segal, E. 1961. Acclimation in molluscs. American Zoology 1:235.

Sekkelsten, G. I. 1988. Effect of handicap on mating success in male shore crabs Carcinus Maenas. Oikos 51:131-134.

Sheridan, J. A. and D. Bickford. 2011. Shrinking body size as an ecological response to climate change. Nature Clim. Change 1:401-406.

Sherr, C. J. 1994. G1 phase progression : cycling on cue. Cell 79:551-555.

Shirley, S. M., T. C. Shirley, and S. D. Rice. 1987. Latitudinal variation in the Dungeness crab, Cancer magister: zoeal morphology explained by incubation temperature. Marine Biology 95:371-376.

Sibly, R. M. and D. Atkinson. 1994. How rearing temperature affects optimal adult size in ectotherms. Functional Ecology 8:486-493.

Silva, I., M. Alves, J. Paula, and S. Hawkins. 2010. Population differentiation of the shore crab Carcinus maenas (Brachyura: Portunidae) on the southwest English coast based on genetic and morphometric analyses. Scientia Marina 74:435-444.

Singer, S. R., M. L. Hilton, and H. A. Schweingruber. 2006. America's lab report: Investigations in high school science. National Academy Press. 
Slabber, S., M. Roger Worland, H. Petter Leinaas, and S. L. Chown. 2007. Acclimation effects on thermal tolerances of springtails from sub-Antarctic Marion Island: Indigenous and invasive species. Journal of Insect Physiology 53:113-125.

Slovic, P., M. L. Finucane, E. Peters, and D. G. MacGregor. 2007. The affect heuristic. European Journal of Operational Research 177:1333-1352.

Sneddon, L. U., F. A. Huntingford, and A. C. Taylor. 1997. Weapon size versus body size as a predictor of winning in fights between shore crabs, Carcinus maenas (L.). Behavioral Ecology and Sociobiology 41:237-242.

Snyder, W. E. and E. W. Evans. 2006. Ecological effects of invasive arthropod generalist predators. Annual Review of Ecology, Evolution, and Systematics 37:95-122.

Somero, G. 2005. Linking biogeography to physiology: Evolutionary and acclimatory adjustments of thermal limits. Frontiers in Zoology 2:1.

Somero, G. N. 2002. Thermal physiology and vertical zonation of intertidal animals: optima, limits, and costs of living. Integrative and Comparative Biology 42:780-789.

Somero, G. N. 2010. The physiology of climate change: how potentials for acclimatization and genetic adaptation will determine 'winners' and 'Iosers'. Journal of Experimental Biology 213:912-920.

Somero, G. N. 2012. The Physiology of global change: Linking patterns to mechanisms. Annual Review of Marine Science 4:39-61.

Sørensen, J. G., T. N. Kristensen, and V. Loeschcke. 2003. The evolutionary and ecological role of heat shock proteins. Ecology Letters 6:1025-1037.

Sorte, C. B. and G. Hofmann. 2005. Thermotolerance and heat-shock protein expression in Northeastern Pacific Nucella species with different biogeographical ranges. Marine Biology 146:985-993.

Sorte, C. J. and G. E. Hofmann. 2004. Changes in latitudes, changes in aptitudes: Nucella canaliculata (Mollusca: Gastropoda) is more stressed at its range edge. Marine Ecology Progress Series 274:263-268.

Sorte, C. J., I. Ibáñez, D. M. Blumenthal, N. A. Molinari, L. P. Miller, E. D. Grosholz, J. M. Diez, C. M. D'Antonio, J. D. Olden, and S. J. Jones. 2013. Poised to prosper? A cross-system comparison of climate change effects on native and non-native species performance. Ecology Letters 16:261270.

Speakman, J. R. 2005. Body size, energy metabolism and lifespan. Journal of Experimental Biology 208:1717-1730.

Spooner, E. H., R. A. Coleman, and M. J. Attrill. 2007. Sex differences in body morphology and multitrophic interactions involving the foraging behaviour of the crab Carcinus maenas. Marine Ecology 28:394-403.

Stillman, J. and G. Somero. 1996. Adaptation to temperature stress and aerial exposure in congeneric species of intertidal porcelain crabs (genus Petrolisthes): correlation of physiology, biochemistry and morphology with vertical distribution. Journal of Experimental Biology 199:1845-1855. 
Stillman, J. H. 2002. Causes and consequences of thermal tolerance limits in rocky intertidal porcelain crabs, genus Petrolisthes. Integrative and Comparative Biology 42:790-796.

Stillman, J. H. 2003. Acclimation capacity underlies susceptibility to climate change. Science 301:65-65.

Stillman, J. H. and G. N. Somero. 2000. A comparative analysis of the upper thermal tolerance limits of eastern Pacific porcelain crabs, genus Petrolisthes: influences of latitude, vertical zonation, acclimation, and phylogeny. Physiological and Biochemical Zoology 73:200-208.

Strange, K., J. Vokoun, and D. Noltie. 2002. Thermal tolerance and growth differences in orangethroat darter (Etheostoma spectabile) from thermally contrasting adjoining streams. The American midland naturalist 148:120128.

Sunday, J. M., A. E. Bates, and N. K. Dulvy. 2012. Thermal tolerance and the global redistribution of animals. Nature Clim. Change advance online publication.

Suzuki, Y. and H. F. Nijhout. 2006. Evolution of a polyphenism by genetic accommodation. Science 311:650-652.

Tagatz, M. E. 1971. Osmoregulatory Ability of Blue Crabs in Different Temperature-Salinity Combinations. Chesapeake Science 12:14.

Tepolt, C. K., J. A. Darling, M. J. Bagley, J. B. Geller, M. J. Blum, and E. D. Grosholz. 2009. European green crabs (Carcinus maenas) in the northeastern Pacific: genetic evidence for high population connectivity and current-mediated expansion from a single introduced source population. Diversity and Distributions 15:997-1009.

Therriault, T. W., L. M. Herborg, A. Locke, and C. W. McKindsey. 2008. Risk assessment for European green crab (Carcinus maenas) in Canadian waters.in F. a. O. Canada, editor.

Thresher, R., et al. 2003. Invasion dynamics of the European shore crab, Carcinus maenas in Austrailia. Marine Biology 142:867-876.

Tomanek, L. and G. N. Somero. 1999. Evolutionary and acclimation-induced variation in the heat-shock responses of congeneric marine snails (genus Tegula) from different thermal habitats: implications for limits of thermotolerance and biogeography. Journal of Experimental Biology 202:2925-2936.

Tomanek, L. and M. J. Zuzow. 2010. The proteomic response of the mussel congeners Mytilus galloprovincialis and M. trossulus to acute heat stress: implications for thermal tolerance limits and metabolic costs of thermal stress. The Journal of Experimental Biology 213:3559-3574.

Torchin, M., K. Lafferty, and A. Kuris. 2001. Release from parasites as natural enemies: Increased performance of a globally introduced marine crab. Biological Invasions 3:333-345.

Tufte, E. R. 1991. Envisioning information. Optometry \& Vision Science 68:322324. 
Urian, A. G. H., John D. Gilg, Matthew R. 2011. Thermal constraints for range expansion of the invasive green mussel, Perna viridis, in the southeastern United States. Journal of Experimental Zoology Part A: Ecological Genetics and Physiology 315A:12-21.

Van Der Meeren, G. I. 1994. Sex-and size-dependent mating tactics in a natural population of shore crabs Carcinus maenas. Journal of Animal Ecology:307-314.

Wada, T. and K. Matsukura. 2007. Seasonal changes In cold Hardiness of the invasive freshwater Apple Snail, Pomacea canaliculata (Lamarck) (Gastropoda: Ampullariidae). Malacologia 49:383-392.

Walne, P. R. and G. J. Dean. 1972. Experiments on predation by the shore crab, Carcinus Maenas L., on Mytilus and Mercenaria. Journal du Conseil 34:190-199.

Walters, Richard J. and M. Hassall. 2006. The temperature-size rule in ectotherms: May a general explanation exist after all? The American Naturalist 167:510-523.

Walton, W. C. 2003. Mitigation of predation by the European green crab Carcinus maenas on publicly cultured hard shell clams Mercenaria mercernaria. Ph.D. Dissertation. University of Maryland, College Park.

Walton, W. C., C. MacKinnon, L. F. Rodriguez, C. Proctor, and G. M. Ruiz. 2002. Effect of an invasive crab upon a marine fishery: green crab, Carcinus maenas, predation upon a venerid clam, Katelysia scalarina, in Tasmania (Australia). Journal of Experimental Marine Biology and Ecology 272:171.

Werner, M. 2001. Prevalence of the parasite Sacculina carcini Thompson 1836 (crustacea, rhizocephala) on its host crab Carcinus maenas (L.) on the West Coast of Sweden. Ophelia 55:101-110.

Wiens, J. J. and C. H. Graham. 2005. Niche conservatism: Integrating evolution, ecology, and conservation biology. Annual Review of Ecology, Evolution, and Systematics 36:519-539.

Wolf, F. 1998. Red and green colour forms in the common shore crab Carcinus maenas (L.) (Crustacea: Brachyura: Portunidae): theoretical predictions and empirical data. Journal of Natural History 32:1807-1812.

Woodward, G., B. Ebenman, M. Emmerson, J. M. Montoya, J. M. Olesen, A. Valido, and P. H. Warren. 2005. Body size in ecological networks. Trends in Ecology \& Evolution 20:402-409.

Yingying, P., Dong, Shengzhang; Yu, Xiaoping. 2008. Effects of temperature stress on development, feeding and survival of the apple snail, Pomacea canaliculata (Lamarck)[J]. Acta Phytophylacica Sinica 3.

Yu, Q., Y. Geng, and P. Sicinski. 2001. Specific protection against breast cancers by cyclin D1 ablation. Nature 411:1017-1021.

Yu, P. C., P. G. Matson, T. R. Martz, and G. E. Hofmann. 2011. The ocean acidification seascape and its relationship to the performance of calcifying marine invertebrates: Laboratory experiments on the development of 
urchin larvae framed by environmentally-relevant $\mathrm{pCO} / \mathrm{pH}$. Journal of Experimental Marine Biology and Ecology 400:288-295.

Yu, H., F. Wan, and J. Guo. 2012. Different thermal tolerance and hsp gene expression in invasive and indigenous sibling species of Bemisia tabaci. Biological Invasions 14:1587-1595.

Zajonc, R. B. 1984. On the primacy of affect. American psychologist 39:117-123.

Zaranko, D. T., D. G. Farara, and F. G. Thompson. 1997. Canadian Journal of Fisheries and Aquatic Sciences 54:809-814.

Zerebecki, R. A. and C. J. B. Sorte. 2011. Temperature tolerance and stress proteins as mechanisms of invasive species success. PLoS ONE 6:e14806.

Zube, E. H., J. L. Sell, and J. G. Taylor. 1982. Landscape perception: research, application and theory. Landscape planning 9:1-33. 


\section{APPENDIX: C/EBP-A EXPRESSION IN INTERTIDAL ORGANISMS}

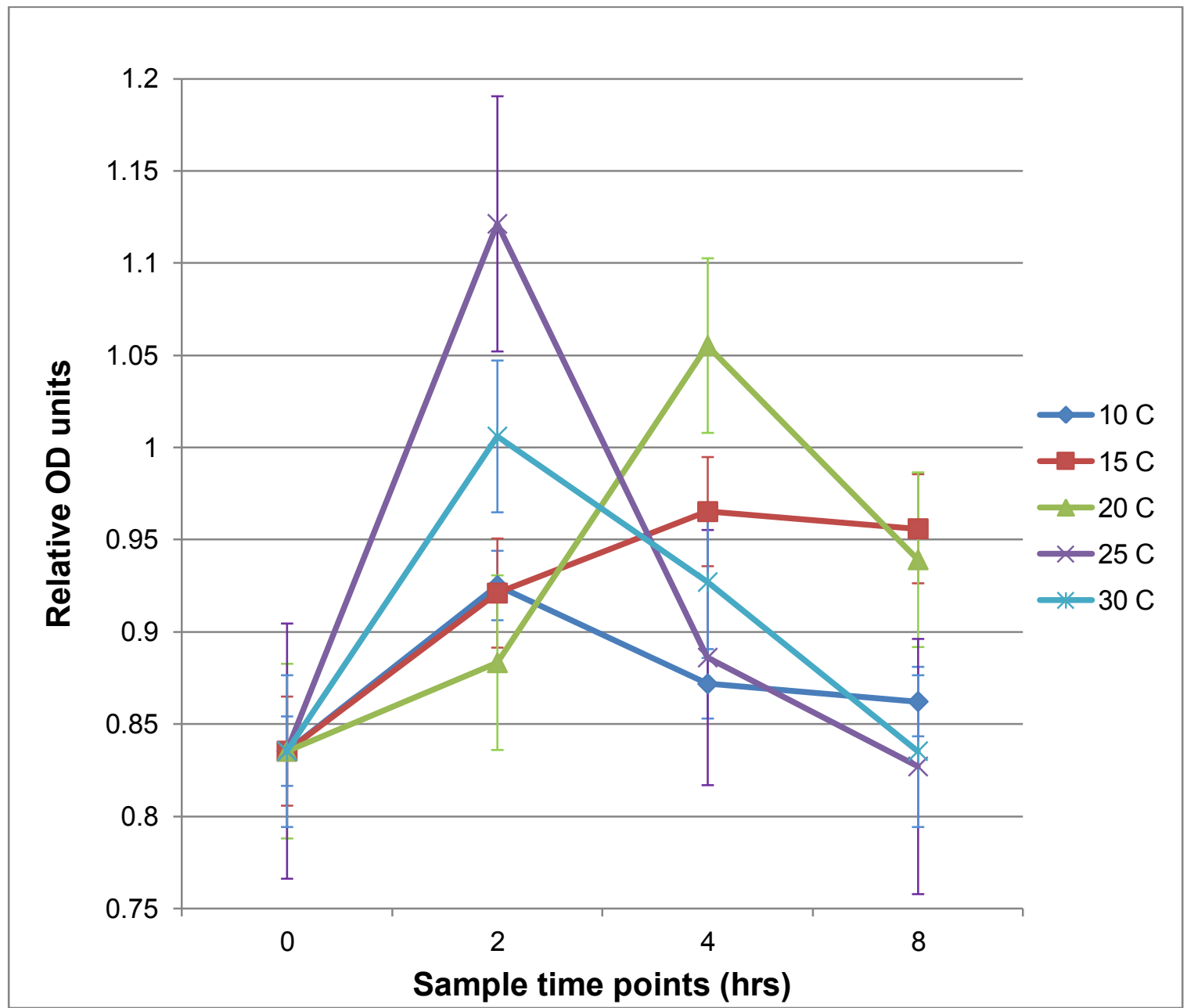

APPENDIX FIGURE 1 RELATIVE PROTEIN LEVELS OF C/EBP-A IN MYTILUS TROSSULUS $(\mathrm{N}=5)$ DURING HEAT STRESS ACROSS 5 DIFFERENT TREATMENT TEMPERATURES AND 4 SAMPLE TIME POINTS, ONE WAY ANOVA WITH REPEAT MEASURES. OVERALL, THE $25^{\circ} \mathrm{C}$ GROUP WAS FOUND TO BE SIGNIFICANTLY DIFFERENT, P<0.047, AND THE 2 HOUR TIME POINT WAS SIGNIFICANTLY DIFFERENT THAN THE 0 HOUR TIME POINT $\left({ }^{*}=\mathrm{P}<0.05\right.$ DUNNETT'S MULTIPLE COMPARISON TEST). ERROR BARS REPRESENT STANDARD ERROR. 


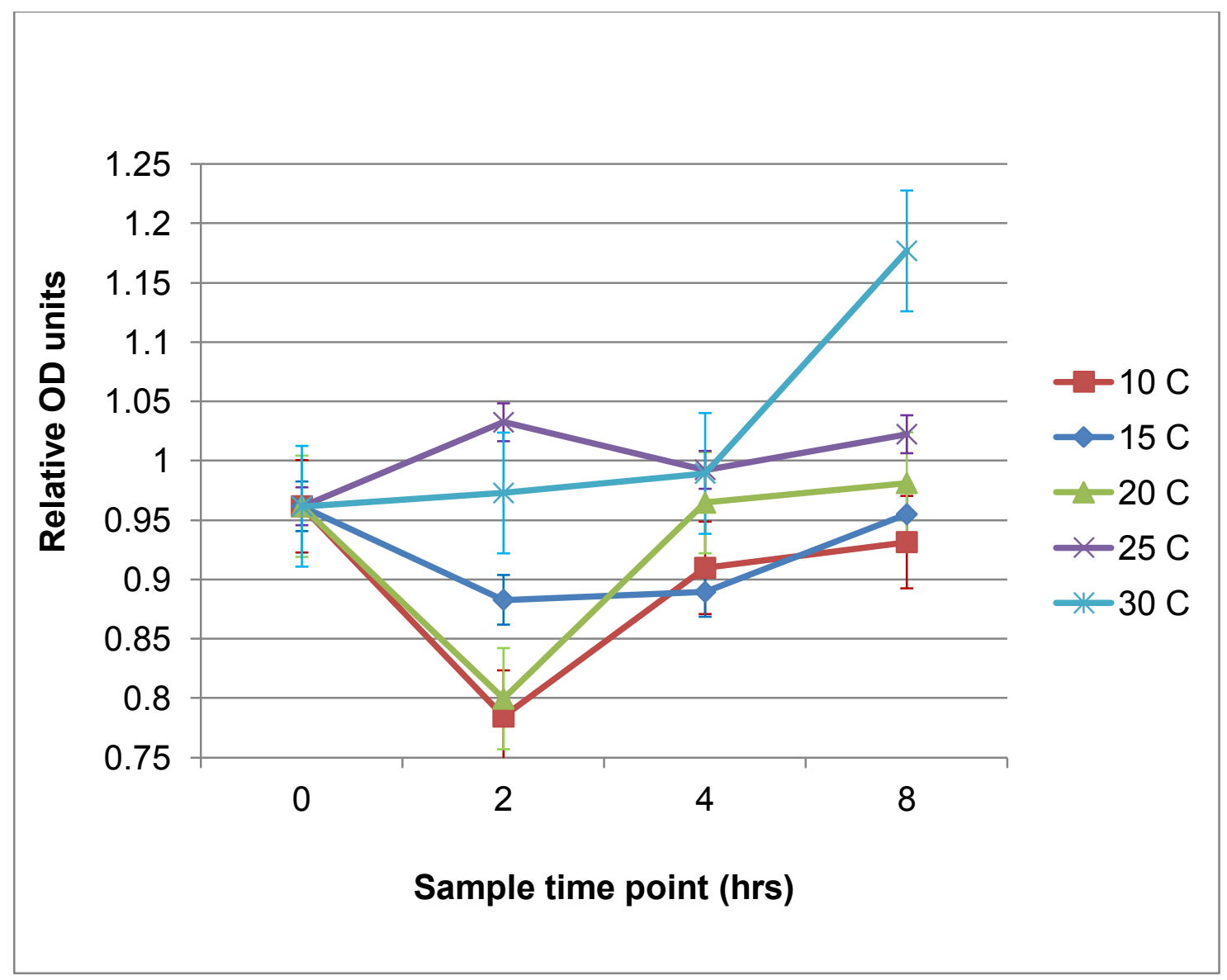

APPENDIX FIGURE 2 RELATIVE PROTEIN LEVELS OF C/EBP $\delta$ IN CHLOROSTOMA FUNEBRALIS DURING HEAT STRESS ACROSS 5 DIFFERENT TREATMENT TEMPERATURES AND 4 SAMPLE TIME POINTS. TREATMENT TEMPERATURE WAS FOUND TO SIGNIFICANTLY AFFECT C/EBP $\delta$ EXPRESSION, $\mathrm{P}=0.050$ (TWO WAY ANOVA, TREATMENT TEMPERATURE, TIME). 


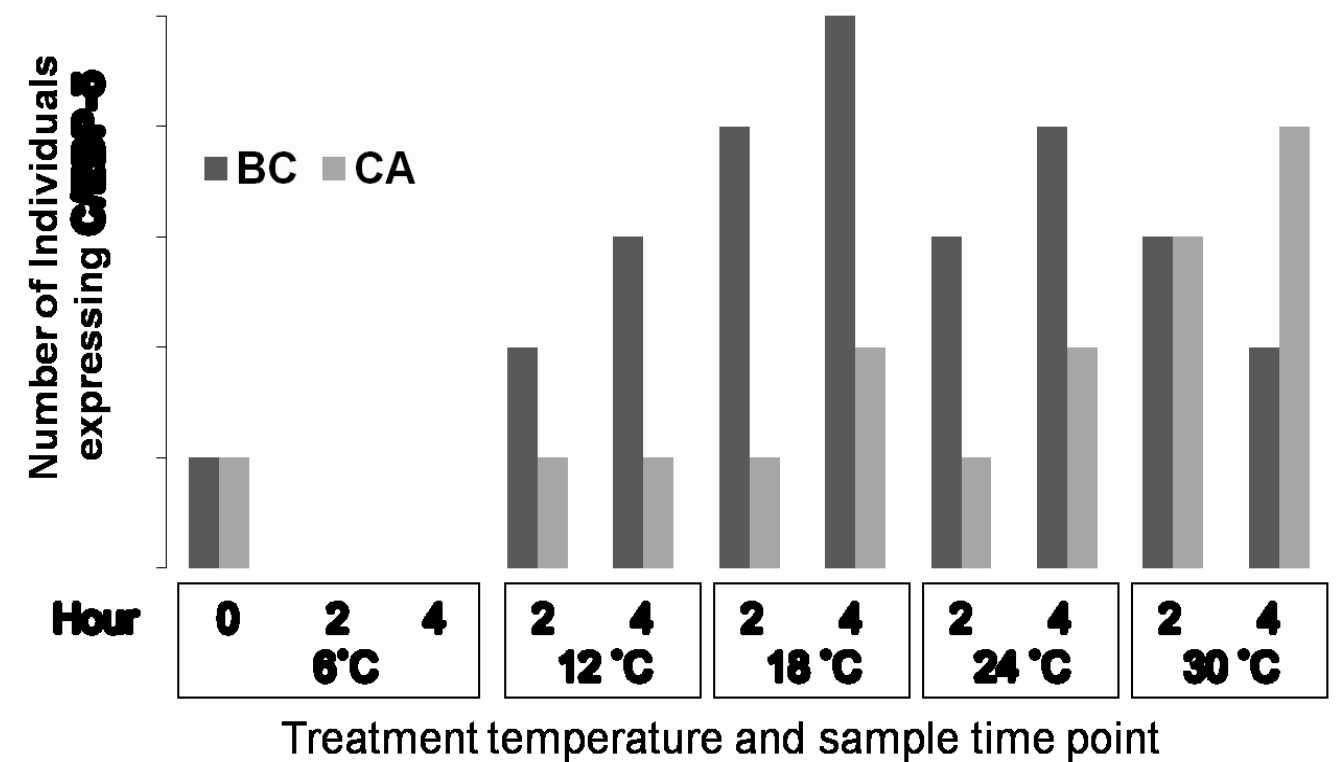

APPENDIX FIGURE 3 RELATIVE LEVELS OF C/EBP $\delta$ IN CARCINUS MEANAS DURING HEAT STRESS AT 0, 2 HR AND 4 HRS AT TREATMENT TEMPERATURES OF $6,12,18,24$, AND $30^{\circ} \mathrm{C}$. 